U. S. DEPARTMENT OF THE INTERIOR

U.S. GEOLOGICAL SURVEY

In Cooperation with the City of Ardmore

\title{
Simulation of effects of wastewater discharges on Sand Creek and lower Caddo Creek near Ardmore, Oklahoma
}

Water-Resources Investigations Report 99-4022

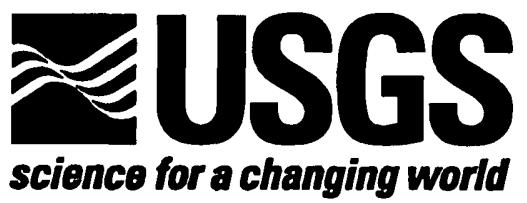




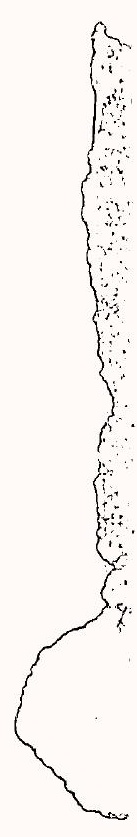

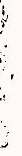

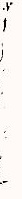


U. S. DEPARTMENT OF THE INTERIOR

U.S. GEOLOGICAL SURVEY

\section{Simulation of effects of wastewater discharges on Sand Creek and lower Caddo Creek near Ardmore, Oklahoma}

By Edwin A. Wesolowski

Water-Resources Investigations Report 99-4022

In Cooperation with the City of Ardmore 
U.S. DEPARTMENT OF THE INTERIOR

BRUCE BABBITT, Secretary

U.S. GEOLOGICAL SURVEY

CHARLES G. GROAT, Director

Any use of trade names in this publication is for descriptive purposes

only and does not imply endorsement by the U.S. Government.

UNITED STATES GOVERNMENT PRINTING OFFICE: OKLAHOMA CITY 1999

For additional information write to:

District Chief

U.S. Geological Survey

Water Resources Division

202 NW 66th Street, Building 7

Oklahoma City, OK 73116

Copies of this report can be purchased from:

U.S. Geological Survey

Branch of Information Services

Box 25286

Denver, CO 80225-0286 


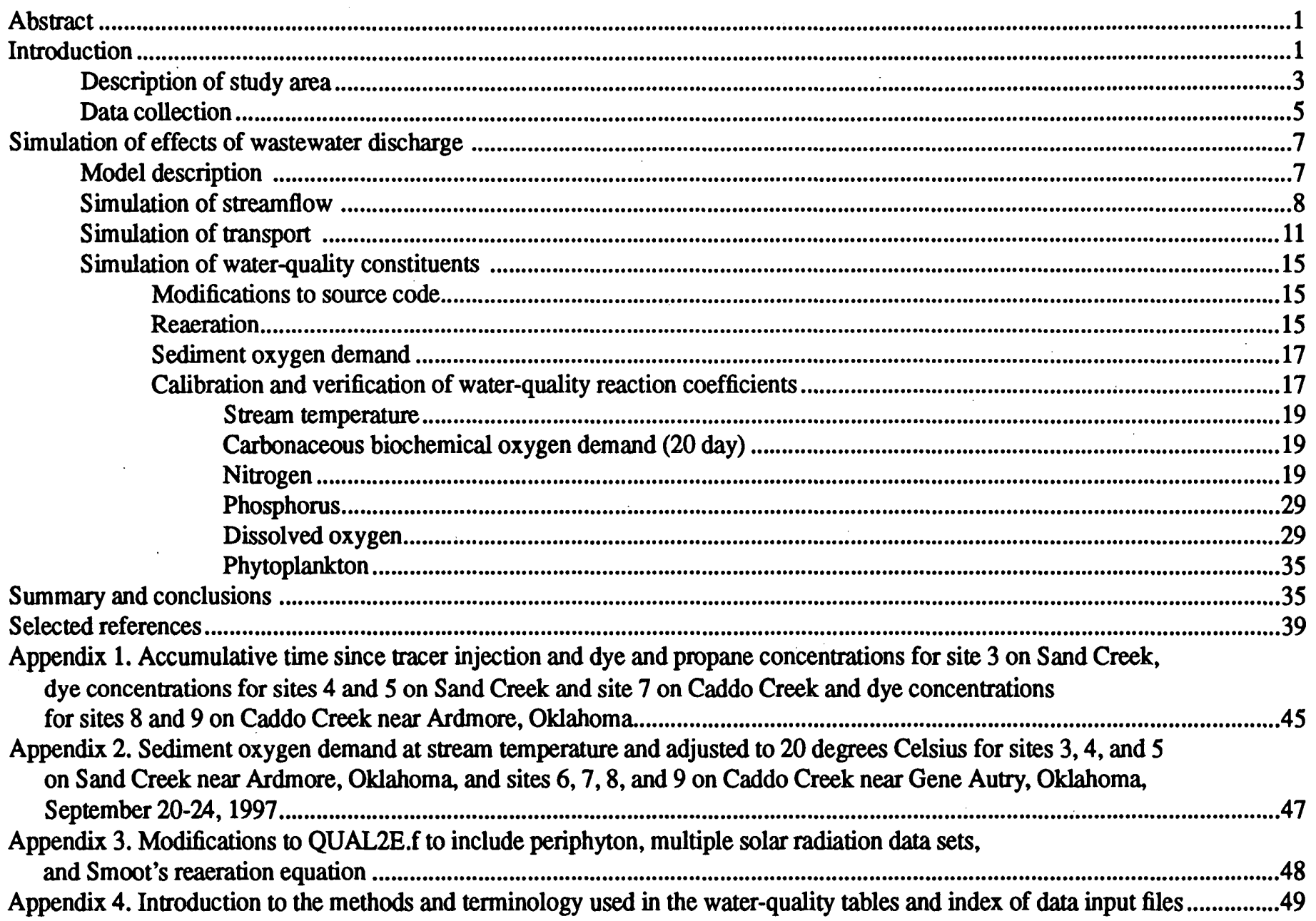

\section{FIGURES}

1. Map showing location of study reach on Sand Creek and Caddo Creek and approximate location of data collection sites. near Ardmore, Oklahoma.

2. Diagram of Sand Creek and Caddo Creek study area in a branch and grid network as used in the

Ardmore Water-Quality Model.

3-4. Graphs showing:

3. Simulated and observed high (June 8-17, 1997), medium (June 18-27, 1997), and low (July 16-19, 1997) streamflow at site 7 (USGS station number 07330700) on Caddo Creek near Gene Autry, Oklahoma, for the Ardmore DAFLOW model.

4. Simulated and observed dye concentrations versus accumulative times for the Sand Creek and Caddo

Creek injections for the Ardmore BLTM Model.

5. Diagram showing constituent interaction in the Ardmore BLTM/QUAL2E Model (model was modified to account for periphyton). 


\section{6. -14. Plots showing:}

6. Simulated and observed temperature at sites 3 and 5 on Sand Creek near Ardmore, Oklahoma, and sites 8 and 9 on Caddo Creek near Gene Autry, Oklahoma, for calibration (July 29-August 1, 1997) and verification (August 26-29, 1997) data sets.

7. Simulated and observed ultimate carbonaceous biochemical oxygen demand at sites 3 and 5 on Sand Creek near Ardmore, Oklahoma, and sites 8 and 9 on Caddo Creek near Gene Autry, Oklahoma, for calibration (July 29-August 1, 1997) and verification (August 26-29, 1997) data sets.

8. Simulated and observed total organic nitrogen as nitrogen concentrations at sites 3 and 5 on Sand Creek near Ardmore, Oklahoma, and sites 8 and 9 on Caddo Creek near Gene Autry, Oklahoma, for calibration (July 29-August 1, 1997) and verification (August 26-29, 1997) data sets.

9. Simulated and observed total ammonia as nitrogen concentrations at sites 3 and 5 on Sand Creek near Ardmore, Oklahoma, and sites 8 and 9 on Caddo Creek near Gene Autry, Oklahoma, for calibration (July 29August 1, 1997) and verification (August 26-29, 1997) data sets.

10. Simulated and observed total nitrite as nitrogen concentrations at sites 3 and 5 on Sand Creek near Ardmore, Oklahoma, and sites 8 and 9 on Caddo Creek near Ardmore, Oklahoma, for calibration (July 29.

August 1, 1997) and verification (August 26-29, 1997) data sets.

11. Simulated and observed total nitrate as nitrogen concentrations at sites 3 and 5 on Sand Creek near Ardmore, Oklahoma, and sites 8 and 9 on Caddo Creek near Gene Autry, Oklahoma, for calibration (July 29 -

August 1, 1997) and verification (August 26-29, 1997) data sets.

12. Simulated and observed total organic phosphorus as phosphorus concentrations at sites 3 and 5 on Sand Creek near Ardmore, Oklahoma, and sites 8 and 9 on Caddo Creek near Gene Autry, Oklahoma, for calibration (July 29-August 1, 1997) and verification (August 26-29, 1997) data sets.

13. Simulated and observed total orthophosphorus as phosphorus concentrations at sites 3 and 5 on Sand Creek near Ardmore, Oklahoma, and sites 8 and 9 on Caddo Creek near Gene Autry, Oklahoma, for calibration (July 29-August 1, 1997) and verification (August 26-29, 1997) data sets.

14. Simulated and observed dissolved oxygen concentrations at sites 3 and 5 on Sand Creek near Ardmore, Oklahoma, and sites 8 and 9 on Caddo Creek near Gene Autry, Oklahoma, for calibration (July 29-August 1, 1997) and verification (August 26-29, 1997) data sets.

15. Graph showing sSimulated dissolved-oxygen concentrations at 3 p.m. and midnight, July 29, 1997, for Sand Creek and Caddo Creek near Ardmore, Oklahoma.

16. Plot showing simulated and observed phytoplankton concentrations at sites 3 and 5 on Sand Creek near Ardmore, Oklahoma, and sites 8 and 9 on Caddo Creek near Gene Autry, Oklahoma, for calibration (July 29-

August 1, 1997) and verification (August 26-29, 1997) data sets.

\section{TABLES}

1. Land use by acre and percentage for Sand Creek and Caddo Creek drainage basins near Ardmore, Oklahoma 4

2. Station number, river miles from site 1 , station name, and description of samples collected at site for the Ardmore Water-Quality Model for Sand and Caddo Creeks near Ardmore, Oklahoma

3. Network branch and grid numbers, subreach, calibrated hydraulic geometry coefficients and exponents, and slope for the Ardmore DAFLOW model for Sand and Caddo Creeks near Ardmore, Oklahoma, using $A=A_{1} Q_{S}^{A_{2}}+A_{0}$ and $W=W_{1} Q_{S}$

4. Network branch and grid number, subreach, calibrated $A_{0}$, decay coefficient, $D Q Q$, and error for the Ardmore BLTM model for Sand and Caddo Creeks near Ardmore, Oklahoma

5. Parameters used to estimate minimum and maximum reaeration coefficients on Sand Creek and Caddo Creek, Ardmore, Oklahoma

6. Maximum, minimum, and average values for selected water-quality constituents, wastewater discharge, and streamflow for the calibration (July 29 - August 1, 1997) data set and verification (August 26-29, 1997) data set for sites 1 and 2 on Sand Creek and site 6 on Caddo Creek near Ardmore, Oklahoma

7. Reaction coefficients, recommended values, variability by subreach, values used, and coefficient description and units in the Ardmore BLTM/QUAL2E model for Sand and Caddo Creeks near Ardmore, Oklahoma

8. Difference between observed and simulated mean concentrations or measurements of the calibration data set for the Ardmore water-quality model for Sand and Caddo Creeks near Ardmore, Oklahoma 24

9. Difference between observed and simulated mean concentrations or measurements of the verification data set for the Ardmore water-quality model for Sand and Caddo Creeks near Ardmore, Oklahoma 


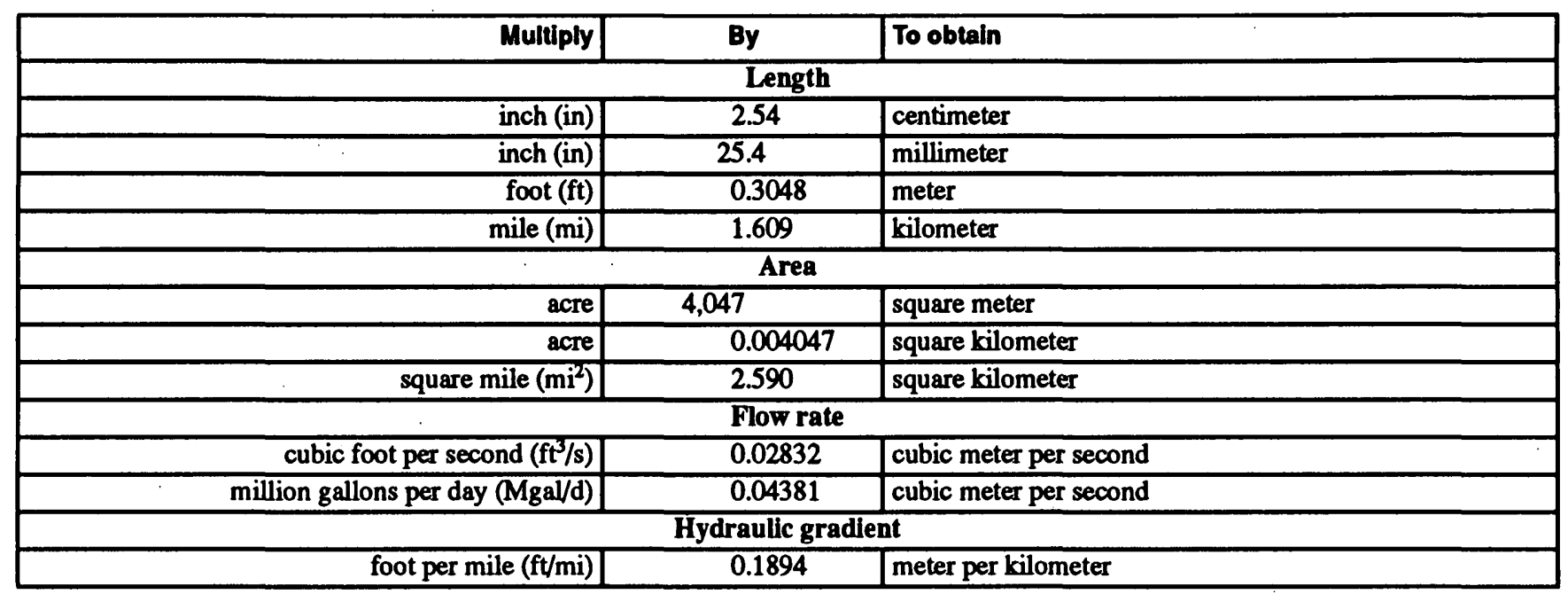

\begin{tabular}{|c|c|c|}
\hline \multicolumn{3}{|c|}{ Area } \\
\hline square centimeter $\left(\mathrm{cm}^{2}\right)$ & 0.1550 & square inch \\
\hline \multicolumn{3}{|c|}{ Volume } \\
\hline liter $(\mathrm{L})$ & 33.82 & ounce, fluid \\
\hline liter $(\mathrm{L})$ & 2.113 & pint \\
\hline liter $(\mathrm{L})$ & 1.057 & quart \\
\hline liter $(L)$ & 0.2642 & gallon \\
\hline \multicolumn{3}{|c|}{ Flow rate } \\
\hline meter per second $(\mathrm{m} / \mathrm{s})$ & 3.281 & foot per second \\
\hline \multicolumn{3}{|c|}{ Pressure } \\
\hline kilopascal (kPa) & 0.1450 & pound-force per inch \\
\hline kilopascal (kPa) & 20.88 & pound per square foot \\
\hline kilopascal (kPa) & 0.1450 & pound per square inch \\
\hline
\end{tabular}

Temperature in degrees Celsius $\left({ }^{\circ} \mathrm{C}\right)$ may be converted to degrees Fahrenheit $\left({ }^{\circ} \mathrm{F}\right)$ as follows:

$$
{ }^{\circ} \mathrm{F}=1.8{ }^{\circ} \mathrm{C}+32
$$

Temperature in degrees Fahrenheit $\left({ }^{\circ} \mathrm{F}\right)$ may be converted to degrees Celsius $\left({ }^{\circ} \mathrm{C}\right)$ as follows:

$$
{ }^{\circ} \mathrm{C}=\left({ }^{\circ} \mathrm{F}-32\right) / 1.8
$$

Sea level: In this report, "sea level" refers to the National Geodetic Vertical Datum of 1929 (NGVD of 1929)--a geodetic datum derived from a general adjustment of the first-order level nets of both the United States and Canada, formerly called Sea Level Datum of 1929.

Altitude, as used in this report, refers to distance above or below sea level.

Specific conductance is given in microsiemens per centimeter at 25 degrees Celsius $\left(\mu \mathrm{S} / \mathrm{cm}\right.$ at $\left.25^{\circ} \mathrm{C}\right)$.

Concentrations of chemical constituents in water are given either in milligrams per liter $(\mathrm{mg} / \mathrm{L})$ or micrograms per liter $(\mu \mathrm{g} / \mathrm{L})$. 



\title{
Simulation of effects of wastewater discharges on Sand Creek and lower Caddo Creek near Ardmore, Oklahoma
}

\author{
By Edwin A. Wesolowski
}

\section{Abstract}

A streamflow and water-quality model was developed for reaches of Sand and Caddo Creeks in south-central Oklahoma to simulate the effects of wastewater discharge from a refinery and a municipal treatment plant.

The purpose of the model was to simulate conditions during low streamflow when the conditions controlling dissolved-oxygen concentrations are most severe.

Data collected to calibrate and verify the streamflow and water-quality model include continuously monitored streamflow and water-quality data at two gaging stations and three temporary monitoring stations; wastewater discharge from two wastewater plants; two sets each of five water-quality samples at nine sites during a 24-hour period; dye and propane samples; periphyton samples; and sediment oxygen demand measurements. The water-quality sampling, at a 6-hour frequency, was based on a Lagrangian reference frame in which the same volume of water was sampled at each site.

To represent the unsteady streamflows and the dynamic water-quality conditions, a transport modeling system was used that included both a model to route streamflow and a model to transport dissolved conservative constituents with linkage to reaction kinetics similar to the U.S. Environmental Protection Agency QUAL2E model to simulate nonconservative constituents. These model codes are the Diffusion Analogy Streamflow Routing Model (DAFLOW) and the branched Lagrangian transport model (BLTM) and BLTM/QUAL2E that, collectively, as calibrated models, are referred to as the Ardmore Water-Quality Model.

The Ardmore DAFLOW model was calibrated with three sets of streamflows that collectively ranged from 16 to 3,456 cubic feet per second. The model uses only one set of calibrated coefficients and exponents to simulate streamflow over this range. The Ardmore BLTM was calibrated for transport by simulating dye concen- trations collected during a tracer study when streamflows ranged from 16 to 23 cubic feet per second. Therefore, the model is expected to be most useful for low streamflow simulations. The Ardmore BLTM/QUAL2E model was calibrated and verified with water-quality data from nine sites where two sets of five samples were collected. The streamflow during the water-quality sampling in Caddo Creek at site 7 ranged from 8.4 to 20 cubic feet per second, of which about 5.0 to 9.7 cubic feet per second was contributed by Sand Creek. The model simulates the fate and transport of 10 water-quality constituents. The model was verified by running it using data that were not used in calibration; only phytoplankton were not verified.

Measured and simulated concentrations of dissolved oxygen exhibited a marked daily pattern that was attributable to waste loading and algal activity. Dissolved-oxygen measurements during this study and simulated dissolved-oxygen concentrations using the Ardmore Water-Quality Model, for the conditions of this study, illustrate that the dissolved-oxygen sag curve caused by the upstream wastewater discharges is confined to Sand Creek.

\section{Introduction}

Sand Creek is an ephemeral stream draining a small area northeast of the city of Ardmore, Oklahoma, (fig. 1). Sand Creek flows into Caddo Creek about 5.54 miles downstream from the outfall of the city of Ardmore wastewatertreatment plant (site 2). Caddo Creek is tributary to the Washita River. Stream flow in Sand Creek is maintained in the summer by treated wastewater from the city of Ardmore and from a petroleum refinery and by ground-water seepage.

The Clean Water Act requires all states to implement a total maximum daily loads process for surface water where water-quality controls are not adequate to achieve instream standards for designated beneficial uses. A total maximum daily loads process results in a loads allocation to all sources, assembling a balance of controls between sources within a drainage basin that will achieve instream standards. The total maximum daily loads process may be implemented in stages. For example, total maximum loads 


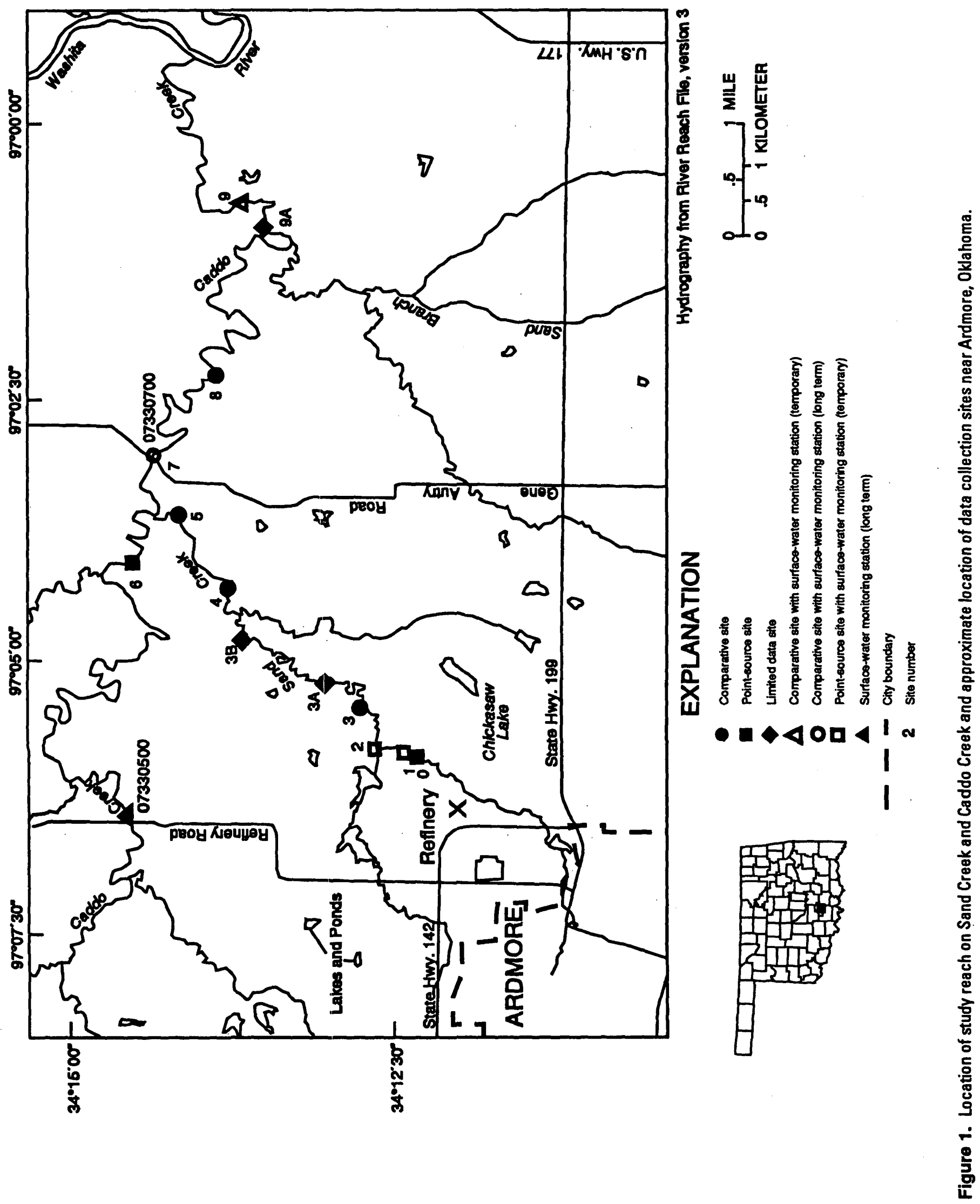


may be limited to point sources only or may include nonpoint sources and selected water-quality constituents. In 1991 the Oklahoma Water Resources Board revised the stream classification of Sand Creek, upgraded the beneficial-use designations to warm water aquatic community and primary body contact recreation from the previous beneficial-use designation of habitat limited aquatic community. The upgraded beneficial-use designation requires a higher quality of water and affects the requirements for the quality of the municipal and industrial wastewater discharged to the creek. The dissolvedoxygen standard requires not less than 4.0 milligrams per liter during 8 hours of a 24-hour period according to the upgraded stream classification for summer (June 1 through October 31), when streamflow is at least 1.0 cubic foot per second upstream of the wastewater plants (Bob Bednar, Oklahoma Department of Environmental Quality, oral commun., 1998). When zero streamflow exists above the wastewater plants, the dissolved-oxygen standard requires not less than 2.0 milligrams per liter as a minimum (Bob Bednar, Oklahoma Department of Environmental Quality, oral commun., 1998). The Oklahoma Department of Environmental Quality has performed preliminary water-quality modeling to determine the point-source total maximum daily loads for Sand Creek and Caddo Creek and has determined wasteload allocations for the city of Ardmore and the refinery. Because of the limitation of the preliminary modeling, these wasteload allocations were made with a stipulation that additional fieldwork be conducted to develop a more refined model (Quang Pham, Oklahoma Department of Environmental Quality, oral commun., 1996).

The quality of treated wastewater is known at the discharge points, but effects on the water quality are largely unknown at downstream reaches of Sand Creek and Caddo Creek. The U.S. Geological Survey, in cooperation with the city of Ardmore, began an investigation in 1996 to (1) select a model that could be used to test the preliminary total maximum daily loads determinations as the loads affect dissolved oxygen during low flows and to simulate water-quality conditions on a subreach of Sand Creek and an subreach of Caddo Creek, (2) collect the data necessary to calibrate and verify the model, and (3) calibrate and verify the model. This report presents the results of that study. The subreaches modeled were 5.86 miles on Sand Creek and 8.14 miles on Caddo Creek. A 5.88-mile subreach on Sand Creek and an 14.58-mile subreach on Caddo Creek constitute a study area where data were collected to calibrate and verify a streamflow and water-quality model.

\section{Description of study area}

Sand Creek and the studied reach of Caddo Creek are wholly or partially in Carter County. Generally, the study area is located northeast of Ardmore, which is in the east-central part of Carter County. Rainfall in Carter County is uniformly dis- tributed throughout the year with a slight peak in spring. Snowfall is infrequent (U.S. Department of Agriculture, 1979, p. 1). The county areal distribution of mean annual precipitation increases from 31 inches in the northwest comer to 39 inches along the southem half of the eastem border (Oklahoma Water Resources Board, 1968, p. 26). Mean annual precipitation at Ardmore is about 37 inches, about 5 inches of which leaves the basin as runoff; evaporation, transpiration, and infiltration account for the remainder. The average winter temperature is $\mathbf{4 6}$ degrees Fahrenheit, and the average daily minimum is 34 degrees.Fahrenheit. The average summer temperature is 83 degrees Fahrenheit, and the average daily maximum is 94 degrees Fahrenheit (U.S. Department of Agriculture, 1979, p. 1).

Carter County is predominantly woodlands and about one-fourth prairie land. The dominant trees are blackjack oak and post oak. The prairie grasses include little bluestem, Indian grass, switch grass, and scattered forbs (U.S. Department of Agriculture, 1979, p. 2). The rocky northern border of the county slopes to steep limestone hills that trend west to east. The terrain of the southem border is nearly level to sloping tree-covered uplands. The rest of the county is composed of very gently sloping to strongly sloping tree-covered ridges and side slopes and narrow to broad, nearly level to gently sloping prairie valleys (U.S. Department of Agriculture, 1979, p. 2). The major land-use categories in the Caddo Creek drainage basin are rangeland and pasture (56.9 percent) and forest (34 percent) (table 1). The major categories in the Sand Creek drainage basin are rangeland and pasture ( 41.0 percent), forest (29.0 percent), and urban and built-up land (25.3 percent). Each of the remaining land-use categories account for less than 2 percent land use in both drainage basins except cropland (3.9 percent) in Caddo Creek (Gary Utley, Natural Resources Conservation Service, written commun., 1997).

Caddo Creek drainage basin extends from the northwestem comer of Carter County east-southeasterly and is 352 square miles. Caddo Creek flows into the Washita River about 9.3 miles from the Caddo Creek and Sand Creek confluence. The average gradient for Caddo Creek is about 7 feet per mile.

The Sand Creek drainage basin is 13.3 square miles. The creek is 8.2 miles long and has an average gradient of about 15 feet per mile.

Vegetation is similar but the species growth pattem and density are different for the two creeks. Vegetation growth patterns and density can affect algal photosynthesis in the creek. Trees line the banks of Caddo Creek but do not shade the entire creek. The land use along the lower part of Caddo Creek is agricultural and forest. The vegetation in the riparian zone of Sand 
Table 1. Land use by acre and percentage for Sand Creek and Caddo Creek drainage basins near Ardmore, Oklahoma

[Percentages do not add up to 100 because of independent rounding; <, less than; source of data the National Resources Conservation Service]

\begin{tabular}{|c|c|c|}
\hline Tame & Acres & Percentage \\
\hline \multicolumn{3}{|c|}{ Sand Creek (a subbasin of Caddo Creek drainage basin) } \\
\hline Cropland & 148.26 & 1.8 \\
\hline Rangeland - open grassland & $2,075.64$ & 25.6 \\
\hline Rangeland - Juniper or Eastern red cedar, low density less than 100 plants per acre & 88.956 & 1.1 \\
\hline Rangeland - Blackjack - Post oak brush, low density - canopy less than 35 percent & 79.072 & 1.0 \\
\hline Pasture land & $1,077.356$ & 13.3 \\
\hline Forest land - bottom land hardwoods & 316.288 & 3.9 \\
\hline Post oak and Blackjack oak - cover type & $2,036.104$ & 25.1 \\
\hline Urban Ranchettes - (House and lot - sizes of 2 to 20 acres) & 39.536 & 0.5 \\
\hline Farmsteads (greater than 5 acres) & 9.884 & 0.1 \\
\hline Cemetery (rural) & 9.884 & 0.1 \\
\hline Pecan Groves and pasture land & 59.304 & 0.7 \\
\hline Urban and built-up land & $2,055.872$ & 25.3 \\
\hline Water & 128.492 & 1.6 \\
\hline Total for Sand Creek & $8,124.648$ & \\
\hline \multicolumn{3}{|l|}{ Caddo Creek drainage basin } \\
\hline Cropland & $8,676.33$ & 3.9 \\
\hline Rangeland - open grassland & $87,109.17$ & 38.9 \\
\hline Rangeland - Juniper and Red Cedar, low density - less than 100 plants per acre & $1,936.86$ & 0.9 \\
\hline Rangeland - Post oak and Blackjack, low density - canopy less than 35 percent & 583.03 & 0.3 \\
\hline Rangeland - Post oak and Blackjack, high density - canopy greater than 35 percent & $1,976.38$ & 0.9 \\
\hline Pasture land 1 & $35,545.28$ & 15.9 \\
\hline Forest - Oak, Hickory, and associated species, greater than 70 percent deciduous & 365.63 & 0.2 \\
\hline Forest - bottom land hardwoods & $10,158.62$ & 4.5 \\
\hline Forest - Post oak and Blackjack oak & $65,645.63$ & 29.3 \\
\hline Urban Ranchettes - (House and lot - sizes 2 to 20 acres) & 909.14 & 0.4 \\
\hline Farmstead (greater than 5 acres) & 217.40 & $<0.1$ \\
\hline Highway - multi-lane (four lanes or more) & 563.27 & 0.3 \\
\hline Oil-waste land & 118.58 & $<0.1$ \\
\hline Quarries and gravel pits, greater than 5 acres & 118.58 & $<0.1$ \\
\hline Cemetery & 59.29 & $<0.1$ \\
\hline Oil and gas well site & 39.53 & $<0.1$ \\
\hline Pecan groves and pasture & $3,537.73$ & 1.6 \\
\hline Urban and built-up land & $4,160.29$ & 1.9 \\
\hline Water (lakes and ponds) & $2,223.43$ & 1.0 \\
\hline Total for all of Caddo Creek & $223,944.18$ & \\
\hline
\end{tabular}

${ }^{1}$ Pasture is rangeland that has been improved by grass seeding other than native grass (Gary Utley, Natural Resources Conservation Service, oral commun., 1998).

Creek changes from the headwater to the mouth from grasses to shrubs then gradually becomes densely forested. In the forested parts, trees shade much of the creek. Land use along Sand Creek includes agriculture, forest, industry, and urban.

Caddo Creek and Sand Creek are characterized by pools and riffles. Pools generally are about 1 to 3 feet deep at base flow. Riffles have cobble, gravel, and sand substrate (Ferrella March, Oklahoma Water Resources Board, oral commun, May 1996). Generally, at low streamflow, Caddo
Creek is wider and shallower and has higher velocities than Sand Creek. At streamflows less than 20 cubic feet per second, the Caddo Creek channel widths range from about 20 to 40 feet, and depths range from less than 1 to 2 feet except in the pools. At streamflows less than 10 cubic feet per second, the Sand Creek channel widths range from less than 10 feet to about 15 feet, and depths range from 1 to less than 3 feet except in pools. The creek banks are regular with usually steep slopes and generally are inaccessible because of thick foliage. Sand Creek below the treatment plants to its confluence with Caddo Creek has varying 
densities of submerged algal macrophytes rooted to the streambed. Algal macrophytes will be referred to as periphyton in this report.

Treated wastewater enters Sand Creek from municipal and industrial sources. The wastewater from the city of Ardmore is treated in a rotating biological contactor system and is continuously discharged through a sloping concrete-step chute to aerate before it enters Sand Creek. Discharge stops about 4 hours weekly to clean the system. The volume of discharge varies according to the amount of influent. The design capacity of the wastewater-treatment plant is 6.2 million gallons per day (about 9.6 cubic feet per second) daily average discharge and 15.5 million gallons per day (24.0 cubic feet per second) peak discharge (Don Stanford, superintendent, Ardmore Wastewater Treatment Plant, oral commun., June 1997). During July 13 through September 27, 1997 , when samples were collected for the study, the range of discharge was 0.4 to 8.2 million gallons per day ( 0.61 to 12.6 cubic feet per second).

The refinery wastewater discharge is mostly continuous, but there are times of no discharge. The refinery wastewater is treated in oil and water separators, operators, and aerated lagoons and discharged from a lagoon through one outfall into a tributary of Sand Creek 0.32 mile upstream from the outfall at the Ardmore treatment plant. The average daily discharge at the refinery wastewater-treatment plant is 0.6 million gallon per day ( 0.9 cubic foot per second), and the maximum discharge is about 1.5 million gallons per day (2.3 cubic feet per second). Typically, during the summer, daily wastewater discharges range from 0.3 to 0.9 million gallon per day ( 0.5 to 1.4 cubic feet per second) (Darcy Jordan, environmental engineer, Total Petroleum, Inc., oral commun., June 1997).

The study area where data were collected encompasses 20.46 river miles on Sand and Caddo Creeks - 5.88 miles on Sand Creek and 14.58 miles on Caddo Creek (fig. 1). The Sand Creek section begins 0.02 mile upstream from where the refinery treated effluent enters Sand Creek and ends at the confluence with Caddo Creek. The Caddo Creek section begins 7.40 miles upstream of the confluence with Sand Creek and extends 7.18 miles downstream from the confluence. Data were collected from 14 sites in the study area. The sampling sites, including the station number, river mile location, station name, and description is listed in table 2.

\section{Data collection}

Data collected to calibrate and verify the water-quality model described in the following section of the report include: (1) continuous (15-minute) streamflow and (hourly) temperature, specific conductance, $\mathrm{pH}$, and dissolved oxygen at two surface-water monitoring stations (station number 07330500 and site 7); (2) continuous (hourly) gage height, temperature, and specific conductance at two surface-water monitoring stations from April through September 1997 (sites 2 and 9); (3) continuous (hourly) temperature and specific conductance at one monitoring station from April through September 1997 (site 2); (4) continuous (hourly) wastewater discharge at two point source sites (wastewater plants; sites 1 and 2); (5) two sets each of five synoptic samples at nine sites during a 24-hour period from

July 29-August 1, 1997, and August 26-29, 1997 (sites 1 to 9); (6) tracer (dye and propane) samples at six sites from July 16-19, 1997 (sites 3 to 5 and 7 to 9); (7) periphyton samples at nine sites during August 1-29, 1997 (sites 3, 3A, 3B, 4, 5, 7 to 9, and 9A); and (8) sediment oxygen demand measurements at seven sites during September 18-24, 1997 (sites 3 to 5 and 6 to 9). The sites where data were collected are described in table 2 , and shown in figure 1. The data are listed in Appendices 1, 2, and 4.

A tracer study was conducted to determine traveltime and reaeration. The calibrated model is expected to be used to simulate water-quality conditions only during low streamflow conditions. Thus, only one tracer study at low streamflow was done. Traveltime measurements were made using methods described in Kilpatrick and Wilson (1989). The modified-tracer technique for the area method developed by Kilpatrick and others (1989) was used to measure reaeration coefficients. Stream reaeration coefficients can be measured using propane gas tracers because the desorption of the gas tracer is related to absorption of oxygen under similar flow conditions. Kilpatrick and others $(1989$, p. 7$)$ describe the formulation and the constant that expresses the ratio of the reaeration rate coefficient to the desorption rate coefficient of propane gas. The tracer data are listed in Appendix 1.

Two separate tracer injections were made, one on Caddo Creek and one on Sand Creek. The Caddo Creek tracer study began with a 1-hour tracer injection at site 6 and ended with sampling at sites 7, 8, and 9. The Sand Creek tracer study began with a one-half hour tracer injection between sites 1 and 2 and ended with sampling at sites 3,4, 5, and 7. Conservative (fluorescent-dye; 20-percent solution of rhodamine WT) and nonconservative (propane-gas; commercial grade) tracers were injected simultaneously into the creeks. Dye samples were collected at midstream (50-percent streamflow line) at varying intervals to define the entire dye cloud until dye concentrations decreased to 2 percent of the peak concentration or 0.2 microgram per liter, whichever was lower. Two dye samples were collected at a time. One sample was analyzed immediately by using one of several field fluorometers. The other dye sample was analyzed in the U.S. Geological Survey, Oklahoma District laboratory. The same calibrated fluorometer was used to measure all dye samples in the laboratory. Gas samples were collected 
Table 2. Station number, river miles from site 1, station name, and description of samples collected at site for the Ardmore Water-Quality Model for Sand and Caddo Creeks near Ardmore, Oklahoma

\begin{tabular}{|c|c|c|c|c|}
\hline $\begin{array}{l}\text { Sito } \\
\text { number }\end{array}$ & $\begin{array}{l}\text { Station } \\
\text { number }\end{array}$ & $\begin{array}{l}\text { River miles } \\
\text { downstrean } \\
\text { from sito } 0\end{array}$ & Station name & Doscription \\
\hline 0 & 07330613 & 0.00 & $\begin{array}{l}\text { Sand Creek site } 0 \text { head water } \\
\text { near Ardmore }\end{array}$ & $\begin{array}{l}\text { No flow during synoptic sampling, no samples collected. Gage height } \\
\text { and water-quality monitoring. }\end{array}$ \\
\hline 1 & 07330615 & 0.02 & $\begin{array}{l}\text { Sand Creek site } 1 \text { point source } \\
\text { from wastewater plant } \\
\text { near Ardmore }\end{array}$ & $\begin{array}{l}\text { Synoptic sampling. Model boundary condition for wastewater } \\
\text { discharge and water quality. Gage height and water-quality } \\
\text { monitoring. }\end{array}$ \\
\hline 2 & 07330618 & 0.34 & $\begin{array}{l}\text { Sand Creek site } 2 \text { point source } \\
\text { from wastewater plant } \\
\text { near Ardmore }\end{array}$ & $\begin{array}{l}\text { Synoptic sampling. Tracer injection. Water-quality monitoring. Model } \\
\text { boundary condition for wastewater discharge and water quality. }\end{array}$ \\
\hline 3 & 07330625 & 0.91 & $\begin{array}{c}\text { Sand Creek site } 3 \text { comparative } \\
\text { sample site near Ardmore }\end{array}$ & Synoptic, tracer, periphyton, and sediment oxygen demand sampling. \\
\hline $3 A$ & 07330630 & 2.23 & $\begin{array}{l}\text { Sand Creek site 3A near } \\
\text { Andmore }\end{array}$ & Periphyton sampling and portable dissolved-oxygen monitor. \\
\hline 3B & 07330635 & 3.64 & $\begin{array}{l}\text { Sand Creek site 3B near } \\
\text { Ardmore }\end{array}$ & Periphyton sampling and portable dissolved-oxygen monitor. \\
\hline 4 & 07330665 & 4.40 & $\begin{array}{l}\text { Sand Creek site } 4 \text { comparative } \\
\text { sample site near Ardmore }\end{array}$ & Synoptic, tracer, periphyton, and sediment oxygen demand sampling. \\
\hline 5 & 07330680 & 5.51 & $\begin{array}{c}\text { Sand Creek site } 5 \text { comparative } \\
\text { sample site near Ardmore }\end{array}$ & Synoptic, tracer, periphyton, and sediment oxygen demand sampling. \\
\hline-- & 07330500 & $(1)$ & Caddo Creek near Ardmore & $\begin{array}{l}\text { Surface-water flow and water-quality monitoring. Model boundary } \\
\text { condition for streamflow. }\end{array}$ \\
\hline 6 & 07330610 & $(2)$ & $\begin{array}{l}\text { Caddo Creek site } 6 \text { point } \\
\text { source upstream from } \\
\text { Sand Creek confluence } \\
\text { near Ardmore }\end{array}$ & $\begin{array}{l}\text { Synoptic, periphyton, and sediment oxygen demand sampling. Tracer } \\
\text { injection. Model boundary condition for water quality. }\end{array}$ \\
\hline 7 & 07330700 & 6.54 & $\begin{array}{l}\text { Caddo Creek site } 7 \\
\text { comparative sample site } \\
\text { near Gene Autry }\end{array}$ & $\begin{array}{l}\text { Synoptic, tracer, periphyton, and sediment oxygen demand sampling. } \\
\text { Surface-water flow and water-quality monitoring. }\end{array}$ \\
\hline 8 & 07330720 & 8.68 & $\begin{array}{l}\text { Caddo Creek site } 8 \\
\text { comparative sample site } \\
\text { near Gene Autry }\end{array}$ & Synoptic, tracer, periphyton, and sediment oxygen demand sampling. \\
\hline $9 A$ & 07330790 & ${ }^{3} 12.30$ & $\begin{array}{l}\text { Caddo Creek site 9A near } \\
\text { Gene Autry }\end{array}$ & Periphyton sampling. \\
\hline 9 & 07330800 & 13.06 & $\begin{array}{l}\text { Caddo Creek site } 9 \\
\text { comparative sample site } \\
\text { near Gene Autry }\end{array}$ & $\begin{array}{l}\text { Synoptic, tracer, periphyton, and sediment oxygen demand sampling. } \\
\text { Gage height and water-quality monitoring. }\end{array}$ \\
\hline
\end{tabular}

\footnotetext{
${ }^{1}$ Site is 7.40 miles upstream from confluence with Sand Creek.

${ }^{2}$ Site is 0.96 mile upstream from confluence with Sand Creek or 1.62 miles upstream of site 7.

${ }^{3}$ Approximate.
}

(two at a time) at midstream at about one-half the interval of the dye samples. The gas samples were analyzed by the U.S. Geological Survey, Quality of Water Service Unit laboratory in Ocala, Florida. Two gas samples were sent to the laboratory to increase the probability of at least one sample arriving unbroken. If both samples arrived unbroken, only one was analyzed to reduce cost. Dye and gas concentrations are included in Appendix 1.

Two sets of water-quality synoptic samples were collected: one set for the model calibration and the other set for model verification. In order to get a representative sample of the phytoplankton and water quality in the cross section, whole water samples were collected using sediment-sampling techniques (Shelton, 1994). Field water-quality measurements were made with portable multiparameter instruments. These instruments were calibrated before sampling, and were checked several times during synoptic sampling. Since several portable, multiparameter instruments were used at the same site during the 24-hour sampling period, it was necessary that all multiparameter instruments measure concentrations precisely, in accordance with acceptable error. The multiparameter instruments were calibrated, then measurements of a common water sample were made using each multiparameter instrument, and these measurements were compared for consistency. 
The water-quality synoptic sampling was based on a Lagrangian reference frame in which the same parcel of water was sampled at each site. Dye concentrations were monitored at six sampling sites on Sand and Caddo Creeks following a slug injection of fluorescent dye (rhodamine WT) into Sand Creek a short distance upstream from the site 2 outfall, Synoptic sampling began when the peak dye concentration reached a sampling site. Five samples were collected within a 24-hour period using a 6-hour sampling frequency. Samples were analyzed by the U.S. Geological Survey, Quality of Water Service Unit laboratory in Ocala, Florida. Twenty-day carbonaceous biochemical oxygen demand samples (filtered and unfiltered) were analyzed by the Ardmore Central Laboratory in Ardmore, Oklahoma. The U.S. Geological Survey laboratory analyzed samples for total ammonia as nitrogen, total nitrite as nitrogen, total ammonia plus organic nitrogen as nitrogen, total nitrate plus nitrite as nitrogen, total phosphorus as phosphorus, total hydrolyzable plus orthophosphorus as phosphorus, turbidity, phytoplankton and periphyton chlorophyll-a, periphyton biomass (ash weight and total dry weight), and propane. Field measurements were made of temperature, barometric pressure, specific conductance, dissolved oxygen, $\mathrm{pH}$, and alkalinity.

Sediment oxygen demand samples were collected at seven sites - three on Sand Creek and four on Caddo Creek. Murphy and Hicks (1986) describe the methods used to collect samples. Three sediment oxygen demand chambers and one control chamber, to account for the water-column respiration rate, were used at each site. Three open-bottom sediment oxygen demand chambers were placed as to isolate an area on the streambed, and tests were conducted for various durations. It usually required about 3 to 4 hours to get a measurable decrease in dissolved-oxygen concentration. Sediment oxygen demand measurements are listed in Appendix 2. All data collected for this project are published in this report and are stored in the USGS National Water Information System or the Oklahoma District files. The calibration and verification data sets can be accessed at: http://water.usgs.gov/lookup/get?wri99-4022

\section{Simulation of effects of wastewater discharge}

\section{Model description}

A calibrated and verified water-quality model is needed to determine how present and future treated-wastewater discharge from the city of Ardmore and the refinery will affect streamflow quality downstream in Sand Creek and Caddo Creek. Wastewater discharge from the city of Ardmore, while relatively stable, does vary daily and seasonally. Wastewater discharge from the refinery, when flowing, is fairly stable. However, discharge from the refinery can stop for periods that vary from hours to days depending on operating circumstances. Similarly, the streamflows in both Sand Creek and Caddo Creek are unsteady because the streamflow changes with weather conditions. Modeling of both streamflow and transport must account for these dynamic conditions. The pool-and-riffle nature of the study reach also adds to the complexity of the stream hydraulics, making estimation of velocities, depth, and cross-sectional areas both more difficult and more important.

The U.S. Environmental Protection Agency Enhanced Stream Water Quality Model (QUAL2E) is a one-dimensional, steady state, stream water-quality model. The computer program documented by Brown and Bamwell (1987) is widely used and has sophisticated water-quality kinetics. QUAL2E has several limitations, however, when applied to problems like those in this study. First, the model is steady state, thus discharges of both the treated water and the receiving water must be assumed to be unchanging during the period modeled; an unrealistic assumption for this study. Second, stream reaches are assumed to have uniform hydraulics, and computational elements must be uniformly spaced. Finally, QUAL2E does not account for transient storage; the model assumes instantaneous and complete mixing in each model subreach. Given the pool-and-riffle nature of the study reach, a model that incorporates transient storage will better represent the study area.

A transport modeling system was needed that included both a model to route streamflow and a model to transport dissolved conservative constituents with the reaction kinetics to handle nonconservative constituents. The diffusion analogy streamflow routing model (DAFLOW) (Jobson, 1989) and the branched Lagrangian transport model (BLTM) (Jobson and Schoellhamer, 1987) form such a modeling system and were used in this study. DAFLOW is a streamflow model designed to be used in conjunction with BLTM, and produces output files that can be used as input to the BLTM.

DAFLOW is designed to route streamflow and estimate stream velocity for a system of onedimensional open channels with a minimum of field data. A routing model predicts temporal and spatial variations of a flood wave as it traverses a river reach. Therefore, any ungaged inflows (or diversions) must be explicitly added (or subtracted) by imposing those flows as boundary conditions. DAFLOW is a different formulation of the earlier CONROUT model (Doyle and others, 1983). Both DAFLOW and CONROUT are based on the diffusion analogy method (Henderson, 1966) of routing in which the acceleration terms in the Saint-Venant equations are neglected. CONROUT has been used successfully in many applications because of its relative simplicity. The model requires only three parameters all of which have a physical basis. These parameters are $X=$ routing distance, $C o=$ flood-wave celerity (controls traveltime of the wave), and $\mathrm{Ko}=$ 
dispersion coefficient (controls spreading of the wave). Because wave celerity and dispersion coefficients generally vary with streamflow and in a nonlinear fashion, CONROUT requires the parameters be redefined at different ranges of discharge. Calibration over the expected range in streamflows requires a process described as multiple linearization (McQuivy and Keefer, 1974). DAFLOW avoids this problem by defining the parameters in terms of relations between streamflow and hydraulic geometry coefficients and exponents.

At the heart of DAFLOW are two hydraulic geometry equations - one relating cross-sectional area, $A$, to normal discharge, $Q_{S}$, and the other relating width, W, to Qs:

$$
\begin{gathered}
A=A_{1} Q_{S}^{A_{2}}+A_{0} \\
W=W_{1} Q_{S}{ }^{W_{2}}
\end{gathered}
$$

Equation 1 is the equivalent of a rating curve relating area and streamflow. Normal discharge is defined as the steady-state discharge that corresponds to a cross-sectional area of A. Flood-wave celerity, Co, can be shown to be a function of $\frac{\partial Q s}{\partial A} \cdot A_{1}$ is called the hydraulic geometry coefficient and $\mathrm{A}_{2}$ is the hydraulic geometry exponent (Jobson, 1989). Therefore, coefficient $A_{1}$ and exponent $A_{2}$ define the flood-wave celerity. $A_{0}$ is the average cross-sectional area at zero flow and accounts for water stored in pools that would not completely drain if flow ceased. $A_{0}$ would be zero for an ephemeral stream in which there is no standing water at zero flow. Similarly, the hydraulic geometry coefficient for width $W_{1}$ and hydraulic geometry exponent for width $W_{2}$ of equation 2 are important in defining dispersion.

Equations 1 and 2 permit the use of geomorphological relations to estimate the flood-wave celerity and dispersion coefficients using limited data from the study reach. In the absence of geomorphological data for the reach in question, data reported by Leopold and Maddock (1953), Leopold and Miller (1956), Boning (1974), Boyle and Spahr (1985), and Graf (1986) can be used to estimate the hydraulic geometry exponents, allowing the routing model to be calibrated with very limited field data. In this study, a subroutine of the DAFLOW program was used to estimate the hydraulic geometry coefficients and exponents.

The BLTM (Jobson and Schoellhamer, 1987) solves the one-dimensional advective dispersion equation by using a Lagrangian reference frame in which the computational nodes move with the streamflow. This allows the user to follow a specific parcel of water and observe the reactions as that parcel moves through the system. BLTM was an extension of the earlier Lagrangian transport model (LTM) documented by Schoellhamer and Jobson (1986). Recent enhancements to the BLTM link to the QUAL2E routine so that the QUAL2E reaction kinetics can be applied to unsteady flow (Jobson, 1997).

The BLTM has been widely used to examine waterquality processes in rivers. These applications include the Sacramento-San Joaquin Delta and Suisun Marsh in California (Califomia Water Resources Control Board, 1996), the Waccamaw River and the Atlantic Intracoastal Waterway near Myrtle Beach, South Carolina (Drewes and Conrads, 1995), the Colorado River of Arizona (Graf, 1995), the Congaree and Wateree Rivers in South Carolina (Bulak and others, 1993), the New River of West Virginia (Wiley, 1993), and the Chattahoochee River in Georgia (Jobson, 1985).

The following steps were used to calibrate the various coefficients and exponents for the DAFLOW and BLTM, including the QUAL2E subroutine. First, the DAFLOW was calibrated to simulate streamflow; second, the BLTM was calibrated to simulate transport; and last, QUAL2E was calibrated to simulate water-quality constituent concentrations. A naming convention was used to distinguish the various codes (models) and to distinguish between the code and calibrated model. When referring to the model code, the generic names DAFLOW, BLTM, and BLTM/QUAL2E will be used. When referring to the calibrated model, the name Ardmore will precede the generic name. When reference is made to the Ardmore BLTM or the Ardmore BLTM/QUAL2E models, it is implied that the Ardmore DAFLOW model is included. The name Ardmore Water-Quality Model will be used to refer to all three calibrated models.

Initial and boundary conditions for the Ardmore Water-Quality Model input files are located by a branch and grid network. Reaches of the creeks are referred to as branches, and nodes that serve as input and output control points are referred to as grids. The general design of the network layout for the study area consists of 3 branches and 14 grids (fig. 2). The numbering of the branches and grids can change depending upon the input data and which model is being calibrated. Therefore, textural reference to specific branch and grid numbers as shown in figure 2 is not intended for identification of the actual branch and grid numbers as they were used in the input files but only for location within the subreach.

\section{Simulation of streamflow}

The unsteady-flow model DAFLOW was used to determine unsteady streamflow characteristics of the study reach and to provide the necessary streamflow data for the solute-transport model, BLTM. The Ardmore DAFLOW input-data requirements include hydraulic geometry coefficients and hydraulic 


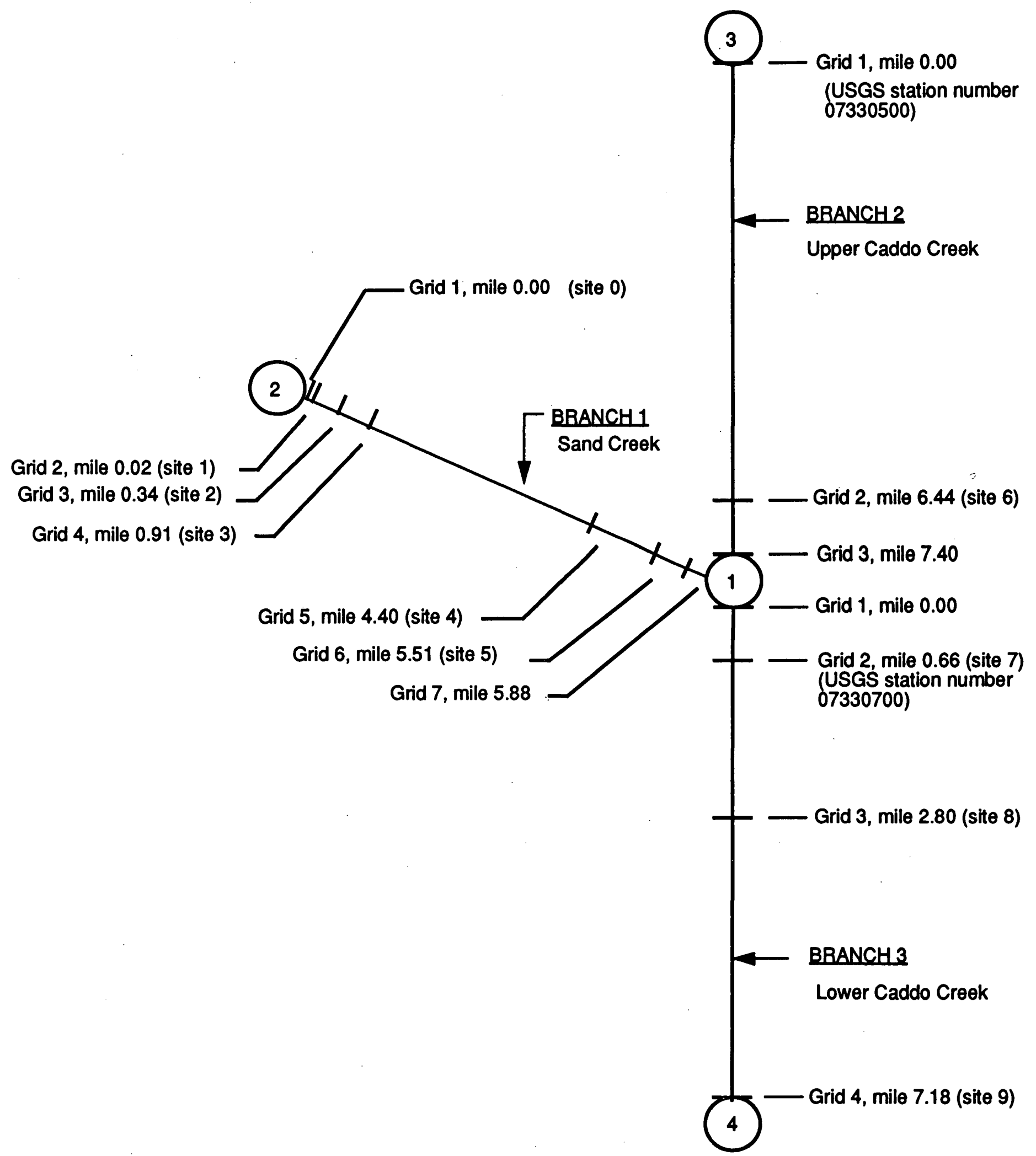

Figure 2. Diagram of Sand Creek and Caddo Creek study area in a branch and grid network as used in the Ardmore Water-Quality Model. 
Table 3. Network branch and grid numbers, subreach, calibrated hydraulic geometry coefficients and exponents, and slope for the Ardmore DAFLOW model for Sand and Caddo Creeks near Ardmore, Oklahoma using $A=A_{1} Q_{S}^{A_{2}}+A_{0}$ and $W=W_{1} Q_{S}^{W_{2}}$

\begin{tabular}{|c|c|c|c|c|c|c|c|c|c|}
\hline $\begin{array}{c}\text { Site } \\
\text { number }\end{array}$ & $\begin{array}{l}\text { Branch } \\
\text { number }\end{array}$ & $\begin{array}{c}\text { Grid } \\
\text { number }\end{array}$ & $\begin{array}{l}\text { Subreach } \\
\text { (mile) }\end{array}$ & $\begin{array}{c}\text { A } \\
\text { (not } \\
\text { reported) }\end{array}$ & $\begin{array}{c}A_{2} \\
\text { (unitloss) }\end{array}$ & $\begin{array}{c}A_{0} \\
\text { (square } \\
\text { fool }\end{array}$ & $\begin{array}{c}\text { Slope } \\
\text { (foot per foot) }\end{array}$ & $\begin{array}{c}W_{1} \\
\text { (not } \\
\text { reportad) }\end{array}$ & $\begin{array}{c}W_{2} \\
\text { (unitlose) }\end{array}$ \\
\hline $1-2$ & 1 & $2-3$ & $0.02-0.34$ & 0.343 & 0.931 & 18.0 & 0.0026 & 7.5 & 0.260 \\
\hline $2-3$ & 1 & $3-4$ & $0.34-0.91$ & 0.343 & 0.931 & 18.0 & 0.0026 & 7.5 & 0.260 \\
\hline $3-4$ & 1 & $4-5$ & $0.91 \cdot 4.40$ & 0.343 & 0.931 & 18.0 & 0.0026 & 7.5 & 0.260 \\
\hline 4-5 & 1 & $5-6$ & $4.40-5.51$ & 0.343 & 0.931 & 20.5 & 0.0026 & 7.5 & 0.260 \\
\hline $5-1$ & 1 & $6-7$ & $5.51 \cdot 5.88$ & 0.343 & 0.931 & 32.0 & 0.0026 & 7.5 & 0.260 \\
\hline $6-^{2}$ & 2 & $2-3$ & $6.44 \cdot 7.40$ & 1.02 & 0.859 & 22.6 & 0.00047 & 6.0 & 0.340 \\
\hline $2-7$ & 3 & $1-2$ & $0.00=0.66$ & 1.08 & 0.893 & 44.0 & 0.00058 & 9.5 & 0.301 \\
\hline $7-8$ & 3 & $2-3$ & $0.66-2.80$ & 1.08 & 0.893 & 44.0 & 0.00058 & 9.5 & 0.301 \\
\hline $8-9$ & 3 & $3-4$ & $2.80-7.18$ & 1.08 & 0.893 & 27.0 & 0.00058 & 9.5 & 0.301 \\
\hline
\end{tabular}

1 Confluence with Caddo Creek.

2 Confluence with Sand Creek.

geometry exponents for the relation between area, width, and streamflow; two upstream streamflow boundary conditions on Sand Creek and one upstream streamflow boundary condition on Caddo Creek; channel slope for both creeks; and a network configuration of branches, grids, and reference distances. The streamflow boundary conditions are input in a 1-hour time-step. DAFLOW model outputs are streamflow, area, top width, and time-step. The DAFLOW model includes an interactive subroutine to estimate hydraulic geometry coefficients and exponents. Another interactive subroutine plots the simulated and observed data and calculates mean errors and root mean squared errors for a given set of hydraulic geometry coefficients and exponents. Hydraulic geometry coefficients and exponents are optimized by trial and error combinations.

The information required to estimate the hydraulic geometry coefficients and exponents was obtained by analyzing periodic streamflow measurements and continuous stage and streamflow data for May 15 through July 19, 1997, for station 07330500 , and sites 7 and 9 . These streamflow and stage data, during the following conditions and time periods, were used to optimize hydraulic geometry coefficients and exponents.

\begin{tabular}{lccc}
\hline \multicolumn{3}{c}{ Site 7 } & \\
\hline $\begin{array}{c}\text { Streamfliow } \\
\text { condition }\end{array}$ & Poriod & $\begin{array}{c}\text { Minimumi } \\
\text { streamflow } \\
\text { (cubic foet } \\
\text { per second }\end{array}$ & $\begin{array}{c}\text { Maximum } \\
\text { streamflow } \\
\text { (cubic foot } \\
\text { per socond) }\end{array}$ \\
\hline High & June 8-17, 1997 & 90 & 3,456 \\
Medium & June 18-27, 1997 & 48 & 278 \\
Low & July 16-19, 1997 & 16 & 23 \\
\hline
\end{tabular}

The results of this optimization are the calibrated Ardmore DAFLOW model. The calibrated hydraulic coefficients and exponents for the Ardmore DAFLOW model are listed in table 3.

For Ardmore DAFLOW calibration, a 3-branch, 14-grid model network was configured to represent the study reach for modeling (fig. 2). The boundary conditions assigned to the model network were: Sand Creek headwater streamflow (site 0) at branch 1, grid 1; the refinery wastewater discharge (site 1) at branch 1, grid 2; city of Ardmore wastewater discharge (site 2 ) at branch 1, grid 3; and Caddo Creek near Ardmore (07330500) streamflow applied at branch 2 , grid 2 (site 6 ). The initial conditions of the model were represented by values at hour zero of the first day of each streamflow data set.

The timing of the simulated and observed peaks at high streamflow is almost identical (fig. 3). The high streamflow range is from 90 to 3,456 cubic feet per second. The smaller peaks occurring at about 48 and 129 hours preceding the larger peaks at about 60 and 148 hours are the peaks due to Sand Creek. The larger peaks originate in Caddo Creek above site 7. The Ardmore DAFLOW model generally underpredicts the streamflow for flood peak derived from Caddo Creek. The underprediction probably is due to unmeasured streamflow that is not being accounted for by the model. The mean error for this simulation is 60 cubic feet per second, and the root mean squared error is 103 cubic feet per second. The overprediction of the Sand Creek peak at hour 48 of the high streamflow simulation results from insufficient attenuation, which could be improved by adjusting the slope used in branch 1 . No changes were made because the emphasis of this study is on the low streamflow range. 
The timing of the simulated and observed peaks at medium streamflow is almost identical, and the agreement between the simulated and observed values is excellent. The medium streamflow range is from 48 to 278 cubic feet per second. However, several simulated recessional peaks are about 2 to 3 hours ahead of the observed peaks. These simulated recessional peaks probably are the result of using the same calibrated hydraulic geometry coefficients and exponents for medium streamflow that apply more closely to high streamflow. The mean error for this simulation is 4.6 cubic feet per second, and the root mean squared error is 7.2 cubic feet per second.

The agreement between the simulated and observed values at low streamflow is excellent. The low streamflow range is from 16 to 23 cubic feet per second. Although the peaks are not distinct, the pattern of variation on about a 24-hour cycle is mostly due to the Ardmore wastewatertreatment plant. However, when this data set was collected, the streamflow in Caddo Creek near Ardmore (07330500) (fig. 1) also was showing a cyclical pattern. This cyclical streamflow is reproduced very well by the model. The mean error for this simulation is -0.30 cubic foot per second, and the root mean squared error is 1.4 cubic feet per second. However, the simulated streamflow tends to be about 6 hours ahead of the observed streamflow. This is the result of using the same calibrated hydraulic geometry coefficients and exponents for the entire range of streamflows. The model hydraulic geometry coefficients and exponents could be recalibrated separately for low streamflow. However, that is not necessary for the intended use of the model in this study.

\section{Simulation of transport}

The Ardmore BLTM was calibrated by simulating dye concentrations measured during a tracer study. Only the dye study will be discussed in this section. The calibration consisted of adjusting $\mathrm{A}_{0}$ (equation 1 ) and $\mathrm{DQQ}$ (dispersion factor) by subreach to reproduce the movement of rhodamine WT dye. Jobson (1989, p. 28) describes the derivation of the DQQ equation. During calibration, dye loss was assumed to be a first-order process, and the value of a decay coefficient was defined so that the mean error in the computed concentrations was forced to zero. During the tracer study, streamflow in Caddo Creek at site 7 ranged from 16 to 23 cubic feet per second, of which about 4 to 8 cubic feet per second was contributed by Sand Creek. The tracer study consisted of two separate tracer injections. The Sand Creek tracer study began with an injection a short distance upstream of where wastewater from site 2 enters the creek. Tracer samples were collected at sites 3, 4, 5, and 7 (fig. 1). The Caddo Creek tracer study began with an injection at site 6 , and samples were collected at sites 7,8 , and 9 .

Calibration was done by separating the model into two branches that followed the two tracer injections: (1) The Sand Creek injection and (2) the Caddo Creek injection. The Sand Creek injection model network consisted of branch 1 and part of branch 3 (fig. 2). The Ardmore BLTM and DAFLOW boundary conditions assigned to the model network at branch 1, grid 4 were: site 3 dye concentrations, the refinery discharge (site 1), and city of Ardmore wastewater discharges (site 2); and at branch 3, grid 1 were: Caddo Creek near Ardmore streamflow (07330500): The Caddo Creek injection model network consisted of most of branch 3. The Ardmore BLTM and DAFLOW boundary conditions assigned to the model network at branch 3, grid 2 were: site 7 dye concentrations and streamflow at branch 3 , grid 2 . The initial model conditions were the dye concentrations and streamflow at hour zero of the first day of each data set. The model was run using a 5-minute time step to simulate the dye peak more accurately. After calibrating $A_{0}$ and DQQ, the Ardmore BLTM and DAFLOW models were reconfigured to a 3-branch, 12-grid network.

The streamflows computed by DAFLOW are independent of the value of $A_{0}$, but it does affect the cross-sectional areas (A in equation 1 ) and, therefore, the transport velocity of a dissolved constituent. During calibration, $A_{0}$ was used to adjust the timing of the simulated concentrations. $A_{0}$ was varied until the simulated and observed concentrations had a minimum root mean squared error. Then the decay coefficient was adjusted until the mean error was forced to zero. A zero mean error indicates that the area under the simulated dye curve is the same as the area under the observed dye curve although the shapes of the two curves may not be identical. Finally, DQQ was calibrated by minimizing the root mean squared error. The calibrated $\mathrm{A}_{0}$, decay coefficient, DQQ, simulated and observed dye-peak concentration, simulated and observed traveltime, and error for the Ardmore BLTM model are listed in table 4. A comparison of the simulated and observed dye-concentration profiles is shown in figure 4.

The calibration process emphasized matching simulated and observed dye peak timings and concentrations. The simulated and observed dye peaks and traveltimes compare very well. Thus, the errors are due to the observed dye concentrations having longer "tails" on recession than the simulated concentrations. The mean and root mean squared errors are small and fairly uniform except for the mean error for the subreach between sites 4 and 5 (table 4). To reduce the mean error to zero would have required a simulated dye peak occurring about three-fourths of an hour earlier, however, this would have increased the root mean squared error. To put these errors in perspective, for the Sand Creek injection, the errors at site 3 are 0.070 (mean) and 0.851 (root mean squared error) microgram per liter, and, for the Caddo Creek injection, the errors at site 7 are -0.042 (mean) and 0.310 (root mean squared 


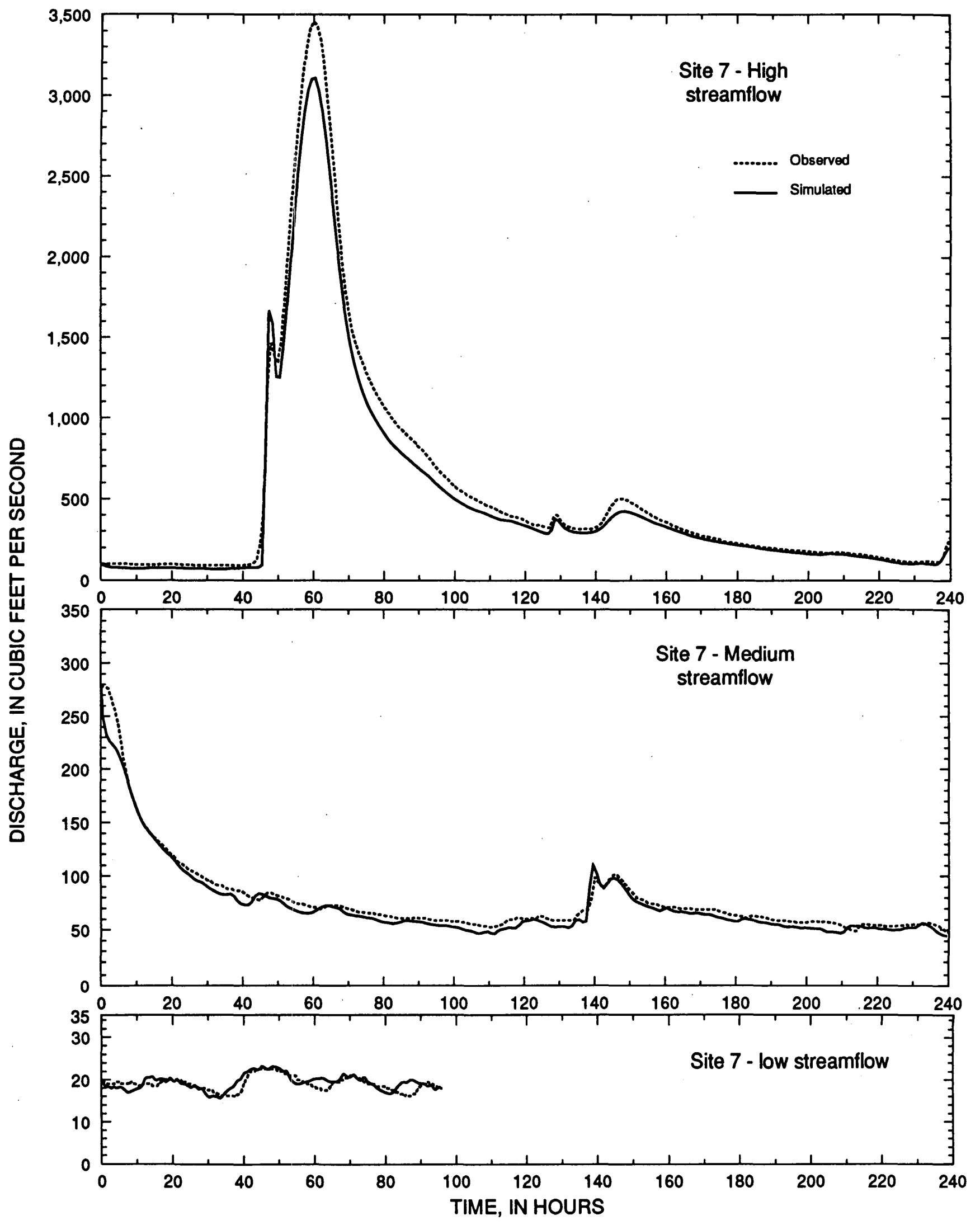

Figure 3. Simulated and observed high (June 8-17, 1997), medium (June 18-27, 1997), and low (July 16-19, 1997) streamflow at site 7 (USGS station number 07330700) on Caddo Creek near Gene Autry, Oklahoma, for the Ardmore DAFLOW model. 


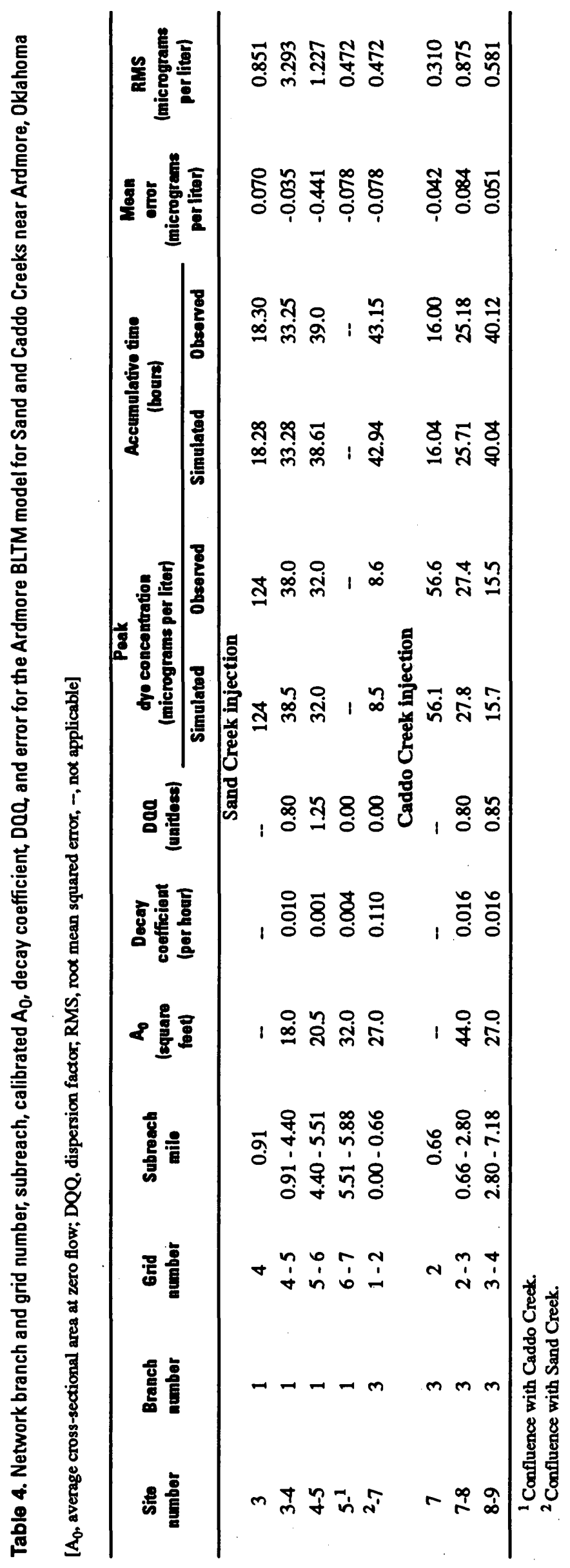




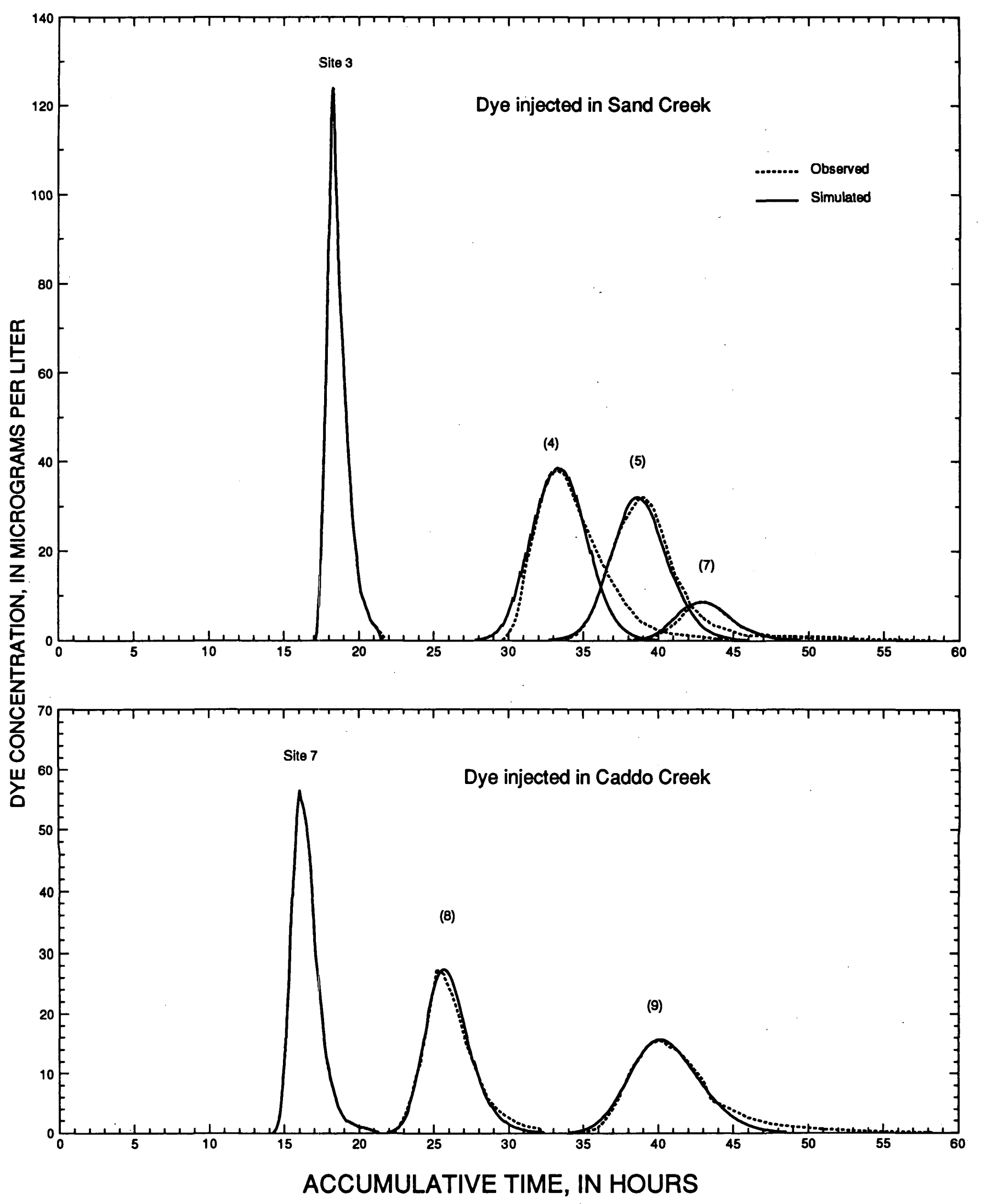

Figure 4. Simulated and observed dye concentrations versus accumulative times for the Sand Creek and Caddo Creek injections for the Ardmore BLTM Model. 
error) microgram per liter. The errors at these two sites represent the smallest errors possible, because they are boundary conditions. No verification of the calibrated Ardmore BLTM was performed.

\section{Simulation of water-quality constituents}

BLTM uses the water-quality reaction kinetics found in the QUAL2E model (Brown and Barnwell,1987; Jobson and Schoellhamer, 1987; Jobson, 1997) to simulate water-quality constituents that affect dissolved-oxygen concentrations. The model also simulates temperature, phytoplankton as chlorophyll-a, nitrogen, phosphorus constituents, and ultimate carbonaceous biochemical oxygen demand. The model can simulate multiple wastewater discharges, withdrawals, tributary streamflows, and incremental inflows and outflows. A diagram of the constituents and their interaction in the BLTM/QUAL2E model is shown in figure 5.

Temperature simulation gives flexibility to the Ardmore Water-Quality Model to be used for other seasons. The rates of most chemical and biological reactions are temperature dependent. The temperature values computed in BLTM/QUAL2E are used to correct the reaction coefficients in the source-sink terms for the water-quality variables. These coefficients are input at 20 degrees Celsius and are corrected to temperature using a Streeter-Phelps-type formulation:

$$
X_{T}=X_{20} \Theta^{\left(T-20^{\circ} C\right)}
$$

where $X_{T}$ is the value of the reaction coefficient at local temperature,

$$
\begin{aligned}
& X_{20} \text { is the value of the reaction coefficient at } \\
& \text { standard temperature of } 20 \text { degrees } \\
& \text { Celsius, } \\
& \Theta \text { is the empirical constant for each } \\
& \text { temperature dependent coefficient } \\
& \text { reaction, and }
\end{aligned}
$$

$\mathrm{T}$ is temperature in degrees Celsius.

The BLTM/QUAL2E uses an equilibrium temperature algorithm to simulate the water temperature (Jobson, 1977, $1980,1997)$. The equilibrium temperature is defined as the water temperature at which the net surface heat exchange becomes zero. Time-series estimates of equilibrium temperature for the calibration and verification time periods were computed within a subroutine of BLTM using inputs of daily extremes of air temperature (and the respective times) and average daily wind speed. The input air temperatures and wind speeds for the city of Ardmore were obtained from the National Oceanic and Atmospheric Administration, National Weather Service.

The BLTM/QUAL2E simulates the growth of phytoplankton. Algal growth rates depend, in part, on available solar radiation. Time-series estimates of solar radiation are computed using longitude, longitude of the local time meridian, latitude, altitude of sunrise and sunset horizons (Jobson, 1997, p. 14), site altitude, coefficients in empirical equation to determine precipitable water content of the atmosphere, sunshine duration, and dew point. The input data were obtained from the National Weather Service. Sand and Caddo Creeks also have substantial growth of periphyton. The growth of these algal groups is different in each creek because of the tree canopy. BLTM/QUAL2E, without modification, could not account for the effect of periphyton nor the capacity to accept more than one set of solar radiation data.

Modifications to source code Several model modifications were made for application to Sand and Caddo Creeks because the physical characteristics of Sand and Caddo Creeks differ with respect to tree canopy. To account for the differences in solar radiation due to the effects of the tree canopy, different solar radiation input data were needed for each creek. The BLTM/QUAL2E was modified to accept two solar radiation values for each time step of the model, one for Sand Creek and one for Caddo Creek. Furthermore, QUAL2E does not simulate the effect of periphyton. These algae grow on the streambeds of both creeks. Periphyton are much more prevalent in Sand Creek, and strongly influence daily cycles in dissolved-oxygen concentration. In order to represent the effect of periphyton on the dissolved-oxygen budget, the quantity of periphyton in mass per unit area of streambed was divided by the depth of the overlying water to convert to an effective concentration in the overlying water. The periphyton concentration then represented a bed source and sink term for dissolved oxygen and nutrients with a magnitude proportional to the growth and respiration rates determined for phytoplankton. In the modified BLTM/QUAL2E, periphyton consume or produce nutrients and oxygen at a rate proportional to the effective periphyton concentration and the availability to light and nutrients, but the actual periphyton concentration remained constant. These model modifications are explained in more detail in Appendix 3.

Reaeration Reaeration refers to exchange of oxygen between the atmosphere and the stream-water column. It is simulated as a first-order process. Reaeration increases the dissolved-oxygen concentration when stream water is undersaturated, as is commonly the case below wastewater discharges. Reaeration will decrease dissolved-oxygen concentration under supersaturated conditions, which may occur due to high levels of algal photosynthesis.

A range for the first-order reaeration coefficient was estimated from the propane-gas study. After the propane was injected in Sand and Caddo Creeks, propane gas was detected only at the first downstream site from 


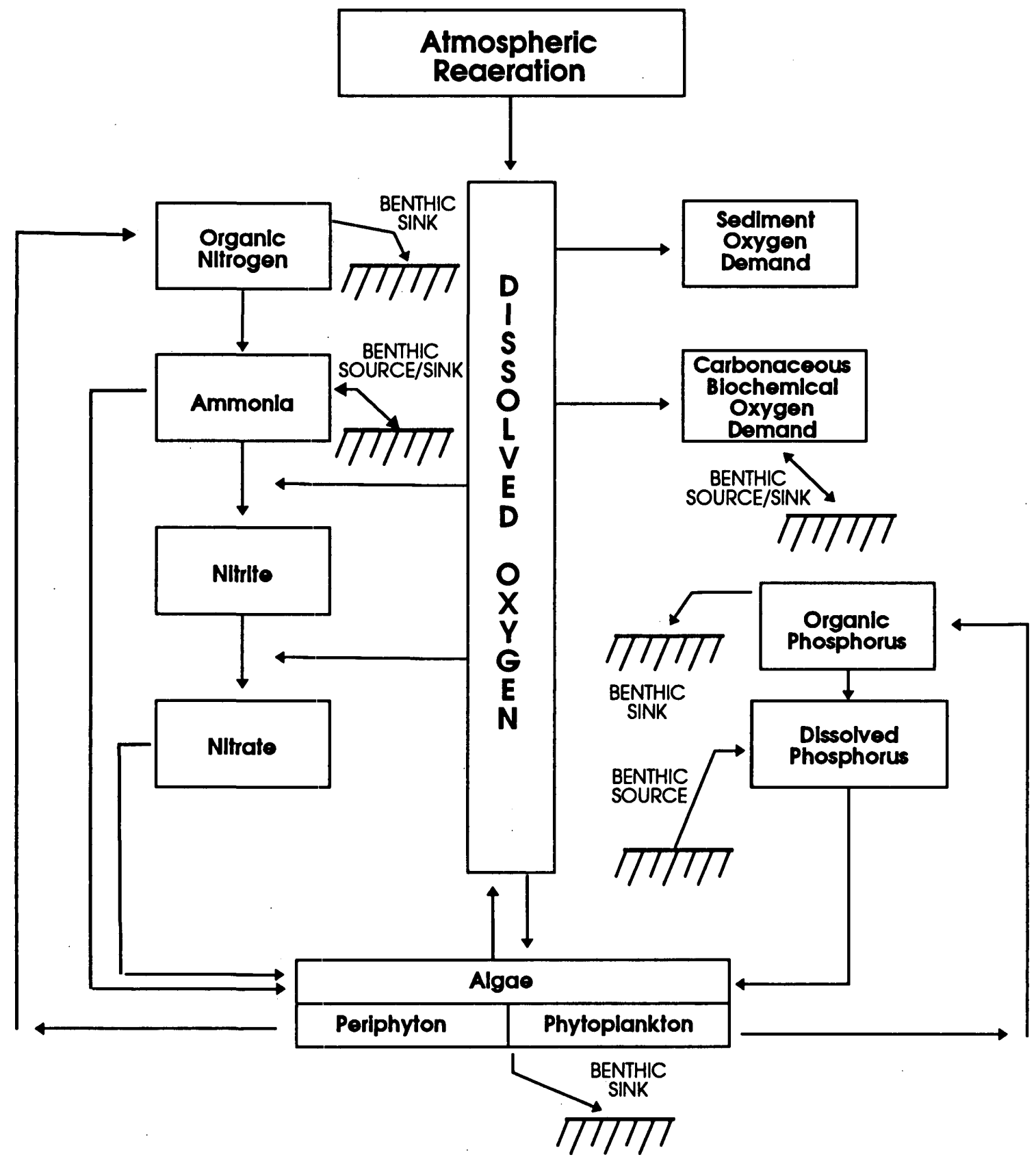

Figure 5. Constituent interaction in the Ardmore BLTM/QUAL2E Model (model was modified to account for periphyton).

injection. This condition probably was caused by a low gas-absorption efficiency because the injection period was not long enough or the creek was too shallow.

The propane-gas data provided enough information to estimate a reaeration coefficient maximum for the subreach between the injection site and first downstream sampling site and a minimum for the subreach between the first two downstream sampling sites (table 5). The mass of the gas injected and the mass of the gas recovered at the first downstream site was used to estimate the maximum reaeration coefficient. The difference between the two gas masses was assumed to be the amount of gas desorbed in the subreach (Kilpatrick and others, 1989, p. 8). Observed or estimated gas and dye peaks at the first two downstream sites from the injection sites were used to estimate the minimum reaeration coefficient. The gas peaks were normalized to dye peaks to account for any loss in concentration due to dispersion and dilution. Because the propane was not detected at the second downstream sampling site at a minimum reporting level of 1 microgram per liter, the calculation included an assumption that the peak gas concentration at the second downstream site was 1 microgram per liter. The estimated reaeration coefficient range, adjusted to 20 degrees Celsius, is 5.0 to 27 per day 
Table 5. Parameters used to estimate minimum and maximum reaeration coefficients on Sand Creek and Caddo Creek, Ardmore, Oklahoma

$\left[\mathrm{K2}_{20(\mathrm{daj}}{ }^{-1}\right)=$ reaeration coefficient at 20 degrees Celsius; $\mu \mathrm{g} / \mathrm{L}$, microgram per liter]

Paramoters used to estimate minimum reaoration

Paranotore used to extimato maximum reaoration

\begin{tabular}{|c|c|c|c|c|c|c|c|c|c|c|c|}
\hline \multirow{2}{*}{$\begin{array}{l}\text { Samplo } \\
\text { site }\end{array}$} & \multirow{2}{*}{$\begin{array}{c}\text { Traveltime } \\
\text { (hours) }\end{array}$} & \multicolumn{2}{|c|}{$\begin{array}{c}\text { Gas poak } \\
(\mu g / L)\end{array}$} & \multicolumn{2}{|c|}{ 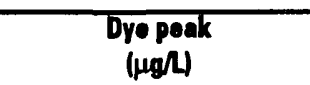 } & \multirow{2}{*}{$\begin{array}{l}K_{2} z_{20} \\
\left(d_{a y}^{-1}\right)\end{array}$} & \multirow{2}{*}{$\begin{array}{l}\text { Iajoction/ } \\
\text { samplo } \\
\text { sitos }\end{array}$} & \multirow{2}{*}{$\begin{array}{l}\text { Traveltime } \\
\text { (hours) }\end{array}$} & \multirow{2}{*}{$\begin{array}{c}\text { Gas } \\
\text { injectod } \\
\text { (grams) }\end{array}$} & \multirow{2}{*}{$\begin{array}{c}\text { Gas } \\
\text { recovored } \\
\text { (grams) }\end{array}$} & \multirow{2}{*}{$\begin{array}{l}\mathbf{K}_{\mathbf{2 0}} \\
\left(\mathrm{day}^{-1}\right)\end{array}$} \\
\hline & & Upstream & Downstream & Upstream & Downstream & & & & & & \\
\hline \multicolumn{12}{|c|}{ Sand Creek injection } \\
\hline 3,4 & 15.0 & 48 & 1 (estimate) & 122 & 39 & 5.0 & $2 / 3$ & 3.3 & 794 & 32.6 & 27 \\
\hline \multicolumn{12}{|c|}{ Caddo Creek injection } \\
\hline 7,8 & 9.5 & 17 & 1 (estimate) & 56.5 & 27 & 6.1 & $6 \pi$ & 6.8 & 1134 & 56 & 12 \\
\hline
\end{tabular}

for Sand Creek and 6.1 to 12 per day for Caddo Creek. The propane gas samples were collected when the water temperature was about 28 degrees Celsius. The empirical constant used in equation 3 to adjust the temperature is 1.024. The estimated minimum reaeration coefficients are probably more accurate than the estimated maximum coefficients. The calculation for the estimated maximum reaeration coefficients includes the gas volume, which may not have gone into solution, but may have bubbled through the water column into the atmosphere. This process would overestimate the volume of gas desorbed in the subreach and result in a larger reaeration coefficient.

Sediment oxygen demand Bowie and others (1985) specify that the sediment-oxygen-demand values are variable, but do recommend a range be used when calibrating a water-quality model. A sediment oxygen demand of 30 milligrams oxygen per square foot per day was used at all the model subreaches in Sand Creek. A sediment oxygen demand of 37 milligrams oxygen per square foot per day was used at all the model subreaches in Caddo Creek. The average values of the sediment-oxygendemand measurements made on Sand and Caddo Creeks are listed in Appendix 2.

Calibration and verification of water-quality reaction coefficients The Ardmore BLTM/QUAL2E model, to be consistent with the Ardmore BLTM and DAFLOW models, was configured to the same 3-branch, 12-grid network to represent the study reach for calibration of reaction coefficients. The point-source boundary conditions for the two 96-hour calibration and verification data sets were assigned to the Ardmore BLTM, DAFLOW, and BLTM/QUAL2E model networks as follows: The refinery wastewater discharge and water quality (site 1) at branch 1 , grid 2; city of Ardmore wastewater discharge and water quality (site 2) at branch 1, grid 3; Caddo Creek near Ardmore streamflow (07330500) and site 6 water quality at branch 2 , grid 2 . These boundary conditions are listed as maximum, minimum, and average values for the water-quality constituents, wastewater discharge, and streamflow for the calibration and verification data sets in table 6. The initial water-quality conditions of the model were represented by average values of each of the 10 constituents over a 24 -hour sampling period. The initial water-quality conditions of the model are those conditions at the beginning of the subreach, which were represented by the water quality of the site associated with that subreach.

Ten constituents were simulated using the Ardmore Water-Quality Model for Sand and Caddo Creeks: water temperature, 20-day carbonaceous biochemical oxygen demand, total organic nitrogen as nitrogen (referred to as organic nitrogen), total ammonia as nitrogen (referred to as ammonia), total nitrite as nitrogen (referred to as nitrite), total nitrate as nitrogen (referred to as nitrate), total organic phosphorus as phosphorus (referred to as organic phosphorus), total hydrolyzable plus orthophosphorus as phosphorus (referred to as orthophosphorus), dissolved oxygen, and phytoplankton (chlorophyll-a). Because of water-quality standards, the water-quality constituent of most interest is dissolved oxygen.

The Ardmore BLTM/QUAL2E model was calibrated using synoptic water-quality data collected July 29-August 1,1997 , and verified using data collected August 26-29, 1997. The periphyton data, collected August 1-29, 1997, was used for calibration and verification. During collection of the water-quality data, the streamflows in Caddo Creek at site 7 ranged from 8.4 to 20 cubic feet per second, of which about 5.0 to 9.7 cubic feet per second was contributed by Sand Creek. Four-day (96-hour) data sets for the 10 modeled constituents were generated for each model boundary for the calibration and verification periods. The water-quality model was calibrated by adjusting kinetic reaction coefficients that applied to either the entire study reach (global) or to 
Table 6. Maximum, minimum, and average values for selected water-quality constituents, wastewater discharge, and streamflow for the calibration (July 29 - August 1, 1997) data set and verification (August 26-29, 1997) data set for sites 1 and 2 on Sand Creek and site 6 on Caddo Creek near Ardmore, Oklahoma

$[<$, less than]

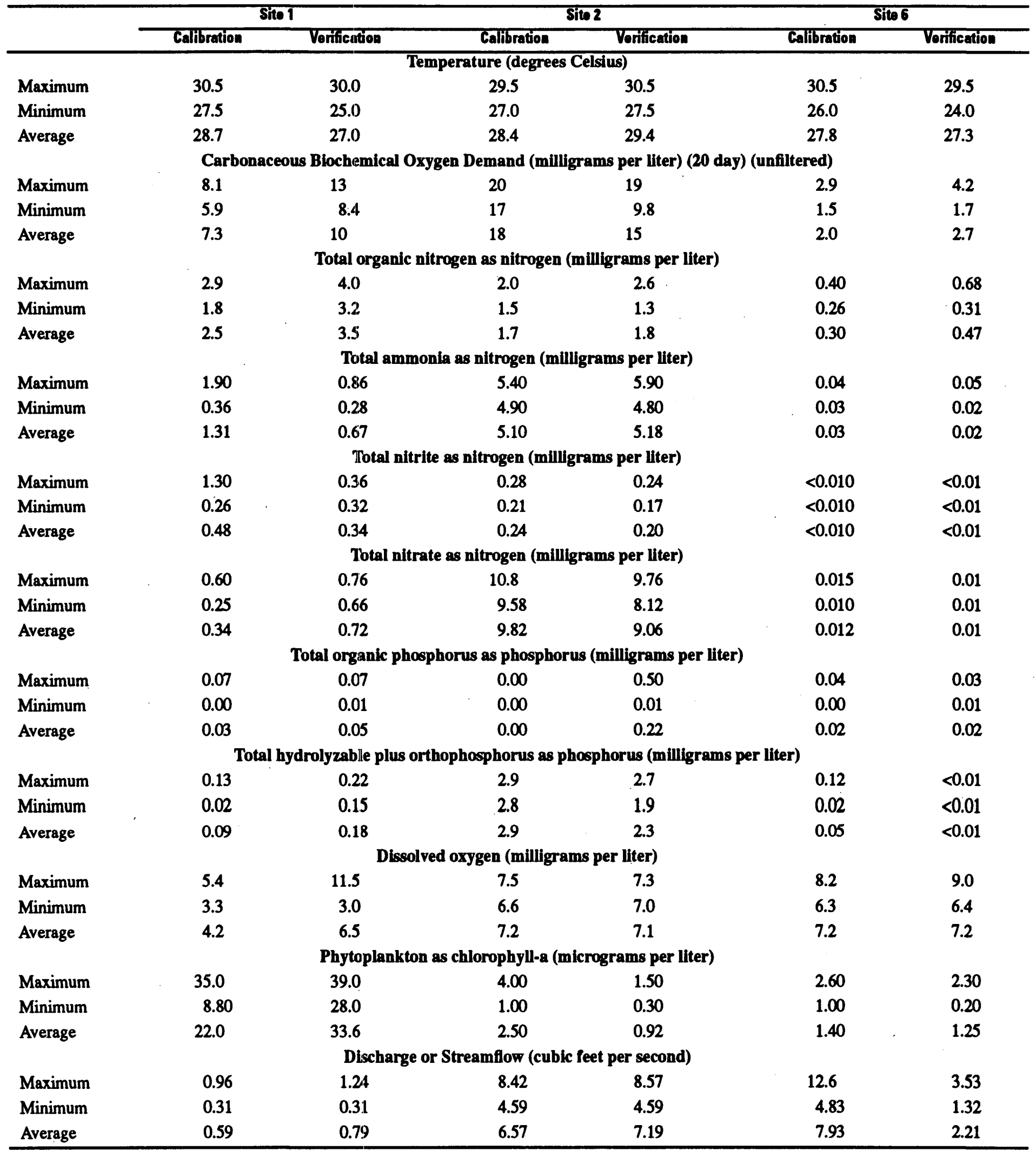


subreaches (local) until the simulated constituent concentrations approximated the measured concentrations. The reaction coefficients, the recommended ranges, whether variable by subreach, and calibrated and verified values are shown in table 7. Two calibrated reaction coefficients had values outside the recommended ranges, nonlinear algal self-shading and organic nitrogen settling rate, as described by Bowie and others (1985) and Brown and Barnwell (1987).

The calibration of the reaction coefficient by constituent proceeded in the downstream direction beginning with the subreach between sites 2 and 3 and ending with the subreach between sites 8 and 9. (When referring to a subreach, only the site numbers will be used and the word "site" will be omitted; for example, subreach 2 to 3). Depending on the constituent, either a single constituent or a group of constituents was calibrated simultaneously. The simulated values were compared with observed values at the end of the subreach. For example, the simulated values for subreach 2 to 3 were compared with the observed values at site 3 . Six sites (three each on Sand and Caddo Creeks) demonstrate the accuracy of the model by analyzing the mean error of the simulated constituent values to the observed values. Only four comparative sites $(3,5,8$, and 9$)$ were selected to illustrate the simulated and observed concentrations. The observed values for all comparative sites are shown in Appendix 4.

\section{Stream temperature}

The model is considered calibrated and verified for stream temperature. The simulated and observed calibration and verification data sets for temperature are shown in figure 6 . The observed water temperatures at the comparative sites varied from 24 to 32 degrees Celsius (site 8) for the calibration data set and 24 to 29.5 degrees Celsius (site 5) for the verification data set, with all sites exhibiting the expected daily cycle. The model does a good job of simulating the daily temperature cycle. The observed and simulated mean temperatures at the comparative sites generally agreed within a range from -2.2 to 1.0 degree for the calibration data set (table 8) and from -0.1 to 1.6 degrees for the verification data set (table 9). These errors could be caused by inaccurate depth simulation or equilibrium temperatures. These errors probably have little effect on the other simulations.

\section{Carbonaceous biochemical oxygen demand (20 day)}

The model is considered calibrated and verified for 20-day carbonaceous biochemical oxygen demand. The BLTM/QUAL2E model calibration used unfiltered 20-day carbonaceous biochemical oxygen demand values. The observed 20-day carbonaceous biochemical oxygen demand concentrations at the comparative sites for the calibration data set varied from a high range of 10 to 14 milligrams per liter (site 3) to a low range of 1.8 to 3.6 milligrams per liter (site 7). The observed 20-day carbonaceous biochemical oxygen demand concentrations at the comparative sites for the verification data set varied from a high range of 8 to . 9.2 milligrams per liter (site 3 ) to a low range of 2.6 to 4.5 milligrams per liter (site 7). The observed 16 milligrams per liter at site 3 in the verification data set appears to be an outlier. The observed 20-day carbonaceous biochemical oxygen demand for both the calibration and verification shows no consistent temporal pattern (fig. 7). The largest decrease in observed concentration (6.6 milligrams per liter mean value) occurs in subreach 3 to 4 . The concentrations decrease at a slower rate for the remainder of Sand Creek. After being diluted by Caddo Creek, the concentrations show only a small decrease except in subreach 7 to 8, where both observed data sets show an increase in concentration. The source of this increase is unknown. The model simulations match the observed data fairly well. All 20-day carbonaceous biochemical oxygen demand calibrated decay rates are within the recommended range of 0.02 to 3.4 per day. The largest calibration decay rates (CK1) occur in subreaches 1 to 2 and 2 to 3 (1.45 per day). The decay rate stays fairly uniform for the remainder of Sand Creek until subreach 4 to 5 where it is reduced to 0.10 per day. To account for the increase in concentration in subreach 7 to 8 of Caddo Creek, the decay rate is reduced to 0.02 per day and settling (CK3) is set to -0.36 per day for subreach 7 to 8 and -0.15 per day for subreach 8 to 9 . Observed and simulated mean concentrations for the calibration data set generally agree within a range from -0.13 to 0.02 milligram per liter (table 8). The observed and simulated 20-day carbonaceous biochemical oxygen demand concentrations for the verification data set generally agree within a range of -1.57 to 0.7 milligram per liter (table 9).

\section{Nitrogen}

The calibration began with organic nitrogen followed by ammonia, nitrite, and nitrate. The simulated and observed calibration and verification data sets for nitrogen (organic, ammonia, nitrite, and nitrate) are shown in figures 8 through 11. Generally, the observed nitrogen constituents show only slight variability during the 24-hour sampling period except for ammonia and nitrate. The daily ammonia and nitrate variation is associated with daily algal variation. Therefore, a minimum local algal settling rate (ALGSET) was used in all subreaches to maximize the daily nitrate variation. The general procedure for calibrated nitrogen was to reduce the mean error for each constituent to zero or to as near to zero as possible. 
Table 7. Reaction coefficients, recommended values, variability by subreach, values used, and coefficient description and units in the Ardmore BLTM/QUAL2E model for Sand and Caddo Creeks near Ardmore, Oklahoma

(n/a=not applicable;]

\begin{tabular}{|c|c|c|c|c|}
\hline Coofficiont & $\begin{array}{l}\text { Recommended } \\
\text { values }\end{array}$ & $\begin{array}{l}\text { Variablo by } \\
\text { subreach }\end{array}$ & Values used & Coofficiont doseription and units \\
\hline$\overline{\mathrm{A1}}$ & $\overline{\mathbf{N} / \mathbf{A}}$ & No & $\overline{0.0}$ & Free convection-wind, in millimeters per day per kilopascal. \\
\hline ALGSET & $0.50-6.00$ & Yes & 0.50 & Local (subreach) algal settling rate, in feet per day. \\
\hline ALPHO & $10.0-100.0$ & No & 50 & $\begin{array}{l}\text { Ratio of chlorophyll-a to algal biomass, in (micrograms chlorophyll-a per } \\
\text { liter) per (milligrams algal biomass per liter). }\end{array}$ \\
\hline ALPH1 & $0.07-0.09$ & No & 0.080 & $\begin{array}{l}\text { Fraction of algal biomass that is nitrogen, in (milligrams nitrogen per liter) } \\
\text { per (milligrams algal biomass per liter). }\end{array}$ \\
\hline ALPH2 & $0.01-0.02$ & No & 0.015 & $\begin{array}{l}\text { Fraction of algal biomass that is phosphorus, in (milligrams phosphorus } \\
\text { per liter) per (milligrams algal biomass per liter). }\end{array}$ \\
\hline ALPH3 & $1.40-1.80$ & No & 1.60 & $\begin{array}{l}\text { Rate of dissolved-oxygen production per unit of algal growth, in milli- } \\
\text { grams (milligrams dissolved oxygen per liter) per (milligrams algal biom- } \\
\text { ass per liter). }\end{array}$ \\
\hline ALPH4 & $1.60-2.30$ & No & 2.00 & $\begin{array}{l}\text { Rate of dissolved-oxygen uptake per unit of algae respired, in (milligrams } \\
\text { dissolved oxygen per liter) per (milligrams algal biomass per liter). }\end{array}$ \\
\hline ALPH5 & $3.00-4.00$ & No & 3.50 & $\begin{array}{l}\text { Rate of dissolved-oxygen uptake per unit of ammonia oxidized to nitrite, in } \\
\text { (milligrams dissolved oxygen per liter) per (milligrams ammonia per liter). }\end{array}$ \\
\hline ALPH6 & $1.00-1.14$ & No & 1.12 & $\begin{array}{l}\text { Rate of dissolved-oxygen uptake per unit of nitrite oxidized to nitrate, in } \\
\text { (milligrams dissolved oxygen per liter) per (milligrams nitrite per liter). }\end{array}$ \\
\hline B1 & N/A & No & 1.13 & $\begin{array}{l}\text { Mass-transfer coefficients in (millimeters per day per kilopascal) per (meter } \\
\text { per second). }\end{array}$ \\
\hline BET1 & $0.1-1.0$ & Yes & $0.1-1.0$ & $\begin{array}{l}\text { Instream reaction rate for biological decay of ammonia to nitrite, in per } \\
\text { day. }\end{array}$ \\
\hline BET2 & $0.20-2.00$ & Yes & $0.2-2.00$ & Instream reaction rate for biological decay of nitrite to nitrate, in per day. \\
\hline BET3 & $0.02-0.40$ & Yes & $0.02-0.40$ & $\begin{array}{l}\text { Instream reaction rate for hydrolysis of organic nitrogen to ammonia, in per } \\
\text { day. }\end{array}$ \\
\hline BET4 & $0.01-0.70$ & Yes & $0.01-0.70$ & $\begin{array}{l}\text { Instream reaction rate for biological decay of organic phosphorus to phos- } \\
\text { phorus, in per day. }\end{array}$ \\
\hline CK1 & $0.02-3.40$ & Yes & $0.02-1.45$ & $\begin{array}{l}\text { Ultimate ( } 20 \text { - day) carbonaceous biochemical oxygen demand decay rate, } \\
\text { in per day. }\end{array}$ \\
\hline CK2 & $0.0-100.0$ & Yes & $5.0-7.5$ & Reaeration coefficient, in per day. \\
\hline CK3 & $-0.36-+0.36$ & Yes & $-0.36-0.00$ & $\begin{array}{l}\text { Rate of loss of ultimate ( } 20 \text { - day) carbonaceous biochemical oxygen } \\
\text { demand caused by settling, in per day. }\end{array}$ \\
\hline CK4 & Variable & Yes & $30 \& 37$ & $\begin{array}{l}\text { Sediment oxygen demand rate, in (milligrams oxygen per square foot) per } \\
\text { (day). }\end{array}$ \\
\hline CKL & $0.07-0.37$ & No & 0.350 & $\begin{array}{l}\text { Michaelis-Menton light half-saturation coefficient for algae, in (calories } \\
\text { per square centimeter) per (minute). }\end{array}$ \\
\hline CKN & $0.01-0.30$ & No & 0.30 & $\begin{array}{l}\text { Michaelis-Menton nitrogen half-saturation coefficient for algae, in milli- } \\
\text { grams nitrogen per liter. }\end{array}$ \\
\hline CKP & $0.001-0.05$ & No & 0.04 & $\begin{array}{l}\text { Michaelis-Menton phosphorus half-saturation coefficient for algae, in mil- } \\
\text { ligrams phosphorus per liter. }\end{array}$ \\
\hline GRO & $1.00-3.00$ & No & 3.00 & Maximum specific algal growth rate, in per day. \\
\hline IGRO & $\begin{array}{l}\text { Options } \\
1,2,3\end{array}$ & No & 2 & $\begin{array}{l}\text { Growth rate option for algae (option } 2 \text {-Algae limited by light and either } \\
\text { nitrogen or phosphorus, but not both). }\end{array}$ \\
\hline $\mathrm{K} 20$ & $\begin{array}{l}\text { Options } \\
1-8\end{array}$ & Yes & 1 & Reaeration option (option 1-read as input). \\
\hline LFO & $\begin{array}{l}\text { Options } \\
1,2,3\end{array}$ & No & Option 1 & Light function option (option 1-half saturation). \\
\hline CB & N/A & Yes & 20,50 & $\begin{array}{l}\text { Periphyton concentration, in milligrams of chlorophyll-a per square foot of } \\
\text { streambed. }\end{array}$ \\
\hline PN & $0.00-1.00$ & No & 0.50 & Algal preference factor for ammonia. \\
\hline RSPRT & $0.05-0.50$ & No & 0.50 & Local algal respiration rate, in per day. \\
\hline SHADO & Variable & No & 0.10 & Nonalgal light-extinction coefficient, in per foot. \\
\hline
\end{tabular}


Table 7. Reaction coefficients, recommended values, variability by subreach, values used, and coefficient description and units in the Ardmore BLTM/QUAL2E model for Sand and Caddo Creeks near Ardmore, Oklahoma - Continued

\begin{tabular}{|c|c|c|c|c|}
\hline Coefficient & $\begin{array}{l}\text { Recommended } \\
\text { values }\end{array}$ & $\begin{array}{l}\text { Variablo by } \\
\text { subreach }\end{array}$ & Values used & Coofficient doseription and units \\
\hline SHAD1 & $0.002-0.02$ & No & 0.003 & $\begin{array}{l}\text { Linear algal self-shading coefficient, in (per foot) per (micrograms chloro- } \\
\text { phyll a per liter). }\end{array}$ \\
\hline SHAD2 & 0.0165 & No & 0.000 & $\begin{array}{l}\text { Nonlinear algal self-shading coefficient, in (per foot) per (micrograms } \\
\text { chlorophyll a per liter) })^{2 / 3} \text {. }\end{array}$ \\
\hline SIG2 & Variable & Yes & 0.000 & $\begin{array}{l}\text { Benthos source rate for phosphorus, in (milligrams phosphorus per square } \\
\text { foot) per (day). }\end{array}$ \\
\hline SIG3 & Variable & Yes & $-115-0.0$ & $\begin{array}{l}\text { Benthos source/sink rate for ammonia, in (milligrams ammonia per square } \\
\text { foot) per (day). Negative values simulate the benthos source rate as an } \\
\text { ammonia sink. }\end{array}$ \\
\hline SIG4 & $0.001-.10$ & Yes & $0.001-2.3$ & Organic nitrogen settling rate, in per day. \\
\hline SIG 5 & $0.001-0.10$ & Yes & 0.10 & Organic phosphorus settling rate, in per day. \\
\hline
\end{tabular}



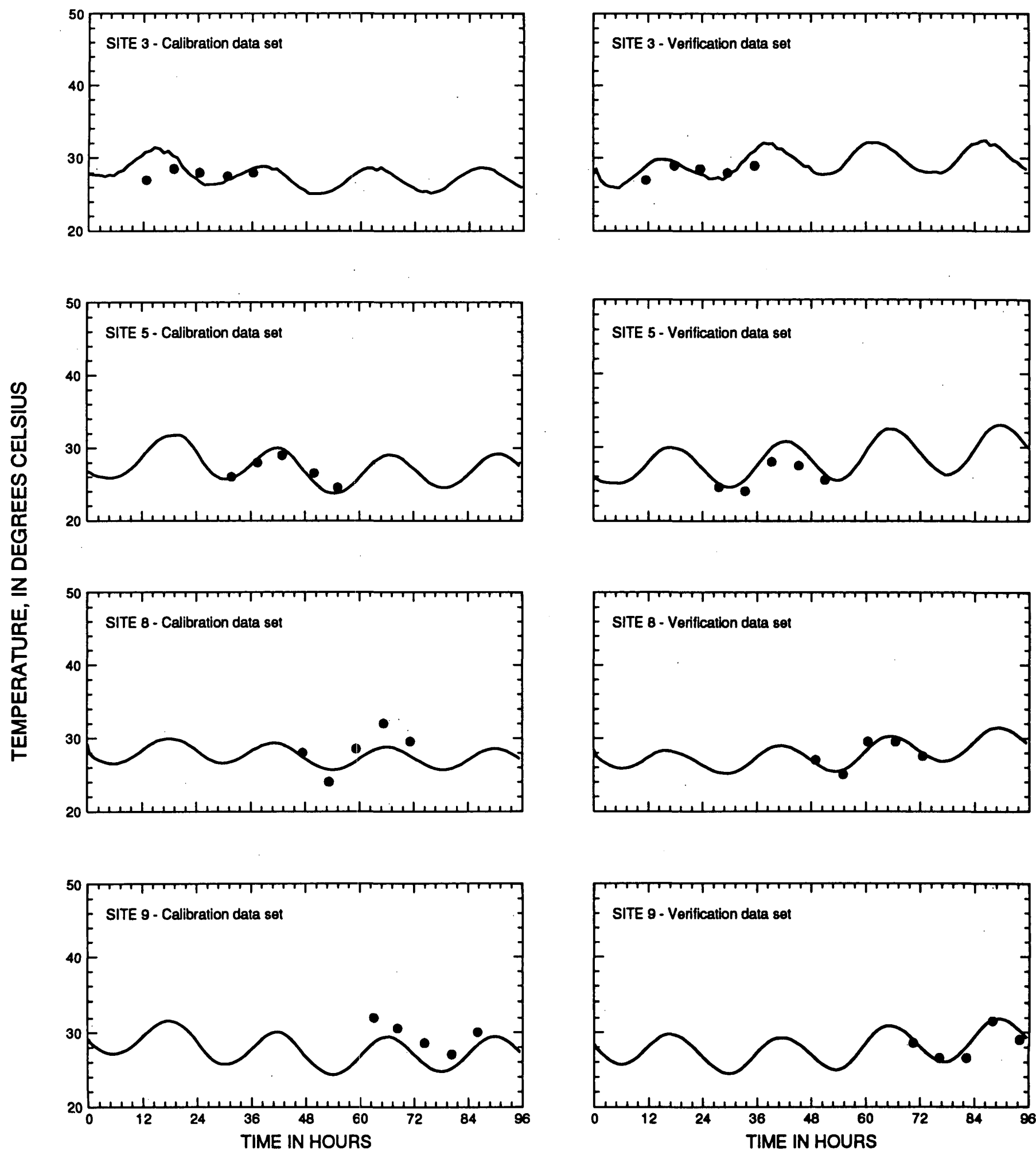

$$
\begin{gathered}
\text { EXPLANATION } \\
\text { Simulated } \\
\text { - Observed }
\end{gathered}
$$

Figure 6. Simulated and observed temperature at sites 3 and 5 on Sand Creek near Ardmore, Oklahoma, and sites 8 and 9 on Caddo Creek near Gene Autry, Oklahoma, for calibration (July 29-August 1, 1997) and verification (August 26-29, 1997) data sets. 


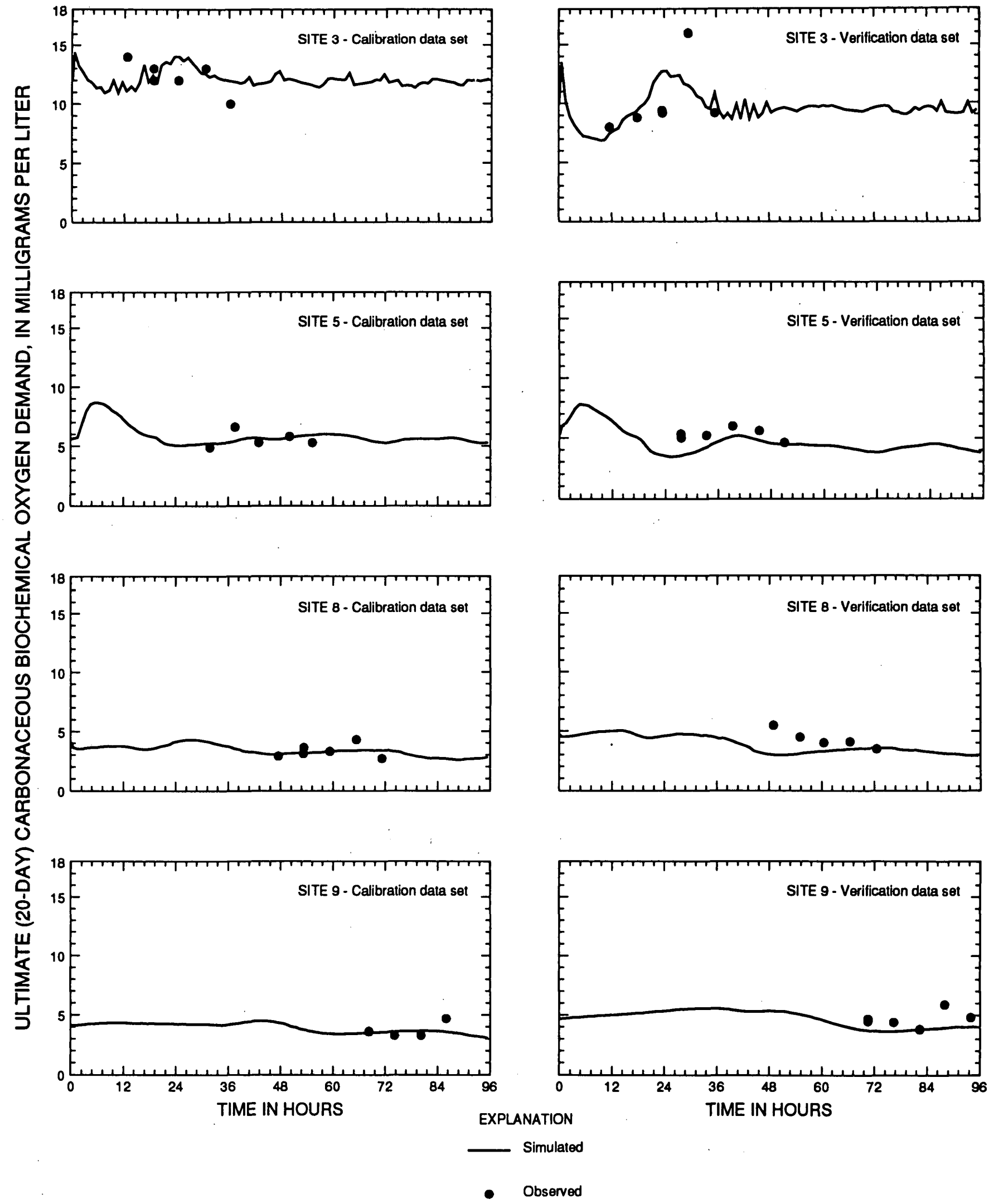

Figure 7. Simulated and observed ultimate carbonaceous biochemical oxygen demand at sites 3 and 5 on Sand Creek near Ardmore, Oklahoma, and sites 8 and 9 on Caddo. Creek near Gene Autry, Oklahoma, for calibration (July 29-August 1, 1997) and verification (August 26-29, 1997) data sets. 


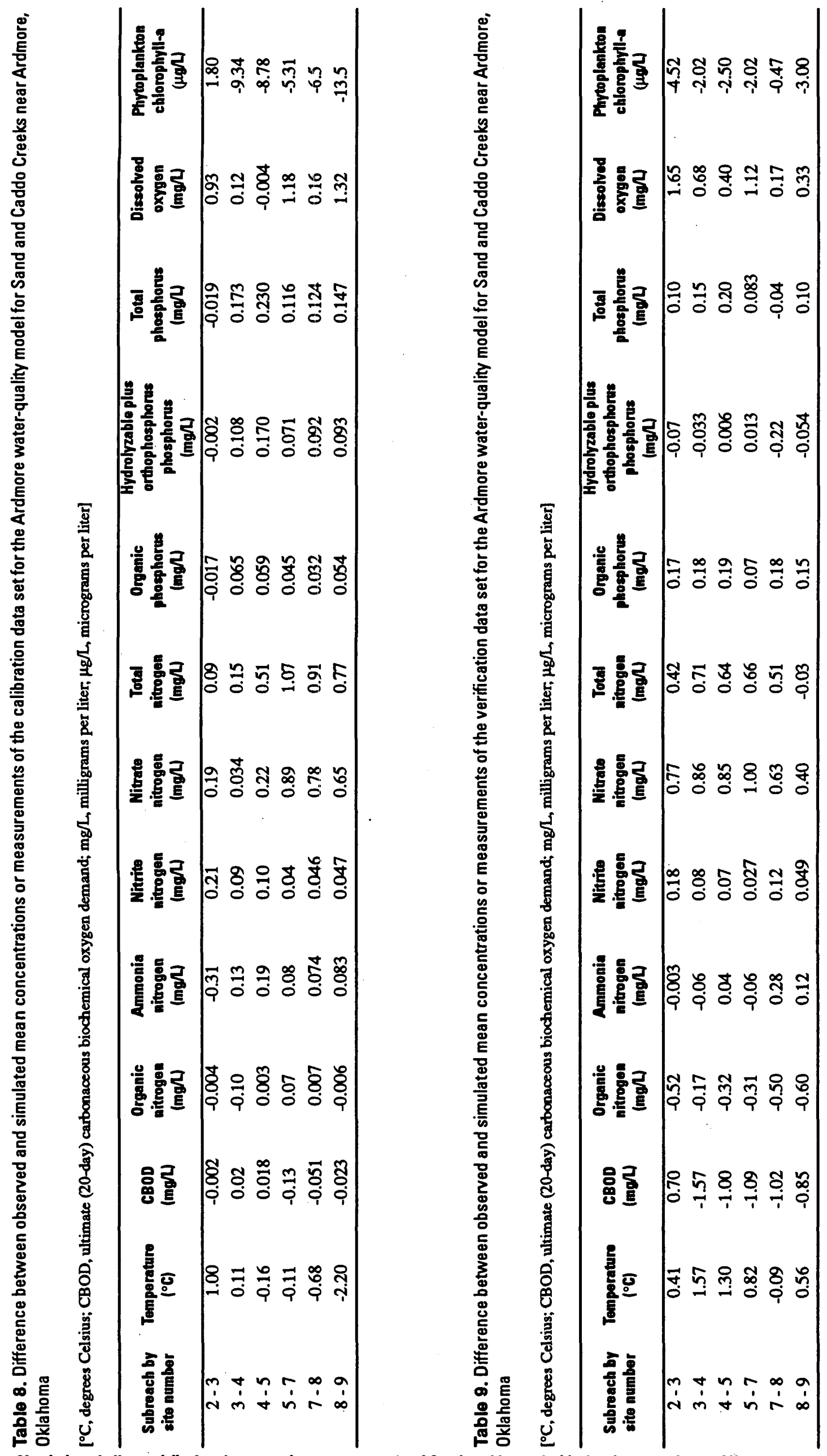




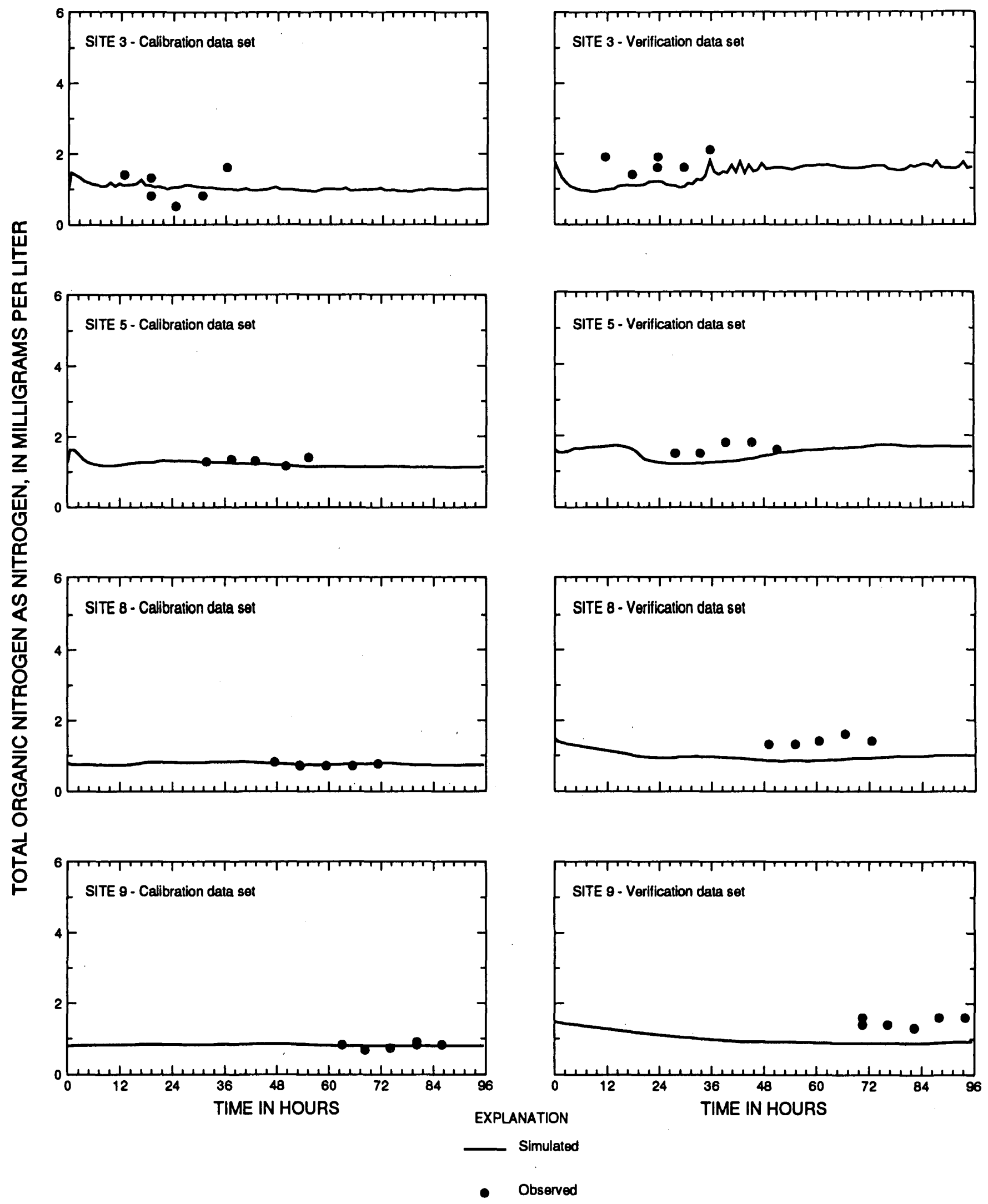

Figure 8. Simulated and observed total organic nitrogen as nitrogen concentrations at sites 3 and 5 on Sand Creek near Ardmore, Oklahoma, and sites 8 and 9 on Caddo Creek near Gene Autry, Oklahoma, for calibration (July 29-August 1, 1997) and verification (August 26-29, 1997) data sets. 
The model is considered calibrated and verified for organic nitrogen. The observed organic nitrogen concentrations at the comparative data sites varied from a high range of 1.24 to 1.80 milligrams per liter (site 4) to a low range of 0.58 to 0.79 milligram per liter (site 7) for the calibration data set and from a high range of 1.4 to 2.1 milligrams per liter (site 3 ) to a low range of 1.1 to 1.4 milligrams per liter (site 7) for the verification data set. The observed organic-nitrogen concentrations decrease downstream in Sand Creek, are diluted by Caddo Creek, then increase slightly downstream from site 7 through site 9 . The decrease in observed concentration is due to settling and hydrolysis to ammonia. The downstream increase in observed concentration may be due to the resuspension of settled organic particulate material or the recycling of dead phytoplankton (Thomann and Mueller, 1987, p. 463). Initial calibration indicated total nitrogen in the study reach needed to be removed. Nitrogen can be removed from the water column by settling of organic nitrogen (SIG4) and by the interaction of ammonia with the streambed (SIG3). Also, nitrogen in various forms is taken up by algae in proportion to the fraction of algal biomass that is nitrogen (ALPH1) and by the algal growth rate (GRO). Not enough organic nitrogen could be removed from the water column using the maximum recommended settling rate of 0.10 per day (table 7 ). Therefore, in order to remove the required organic nitrogen, the settling rate values ranged from 0.001 per day (in subreach 3 to 4 ) to 2.3 per day (in subreaches 1 to 3 ). The calibration settling rate values vary from subreach to subreach. The observed and simulated mean concentrations agree within a range from -0.10 to 0.07 milligram per liter (table 8) for the calibration data set. The calibration settling values provided the necessary amount of organic nitrogen to hydrolyze to ammonia. Maximum hydrolysis (BET3) values ( 0.4 per day) were used in subreaches 1 to 3 . The hydrolysis rates decreased to a minimum 0.02 per day in Caddo Creek. The observed and simulated mean concentrations agree to within a range from -0.17 to -0.60 milligram per liter (table 9 ) for the verification data set. The simulation profile of the verification data set suggests that the calibrated organic nitrogen settling rate may be too high. However, no change was made because the model is not underpredicting total nitrogen, and, on balance, the organic nitrogen simulations are acceptable.

The model is considered calibrated and verified for ammonia. The observed ammonia concentrations at the comparative data sites varied from a high range of 3.90 to 4.40 milligrams per liter (site 3 ) to a low range of 0.05 to 0.10 milligram per liter (site 9 ) for the calibration data set and from a high range of 3.10 to
4.60 milligrams per liter (site 3) to a low range of 0.03 to 0.08 milligram per liter (site 9) for the verification data set. A large decrease in ammonia concentrations occurs between sites 3 and 4 . The mean concentration decreases 3.74 milligrams per liter for the calibration data set and 3.31 milligrams per liter for the verification data set. A large part of the decrease probably is due to uptake by periphyton because nitrification (the oxidation of ammonia to nitrite and nitrate) cannot account for the large decrease in concentration. The ammonia concentrations continue to decrease in Sand Creek downstream of site 4. The reaction coefficient for oxidation of ammonia (BET1) varied from 1.0 per day in subreaches 1 to 3 to 0.01 per day from subreach 4 to 5 to the end of Sand Creek. Only minimum ammonia oxidation occurs in Caddo Creek to the end of the study reach after dilution by Caddo Creek. Benthos source rates (SIG3) were assigned negative values, -115 milligrams ammonia per square foot per day in subreach 3 to 4 and -45 in subreach 4 to 5 . The negative value simulates the benthos source rate as an ammonia sink. The negative values were assigned to calibrate the model to simulate the large decrease in ammonia concentration in subreach 3 to 4 and a smaller decrease in subreach 4 to 5 . The benthos source rate was zero for the rest of the subreaches.

The observed and simulated mean concentrations for the calibration data set agree within a range from -0.31 to 0.19 milligram per liter (table 8). The observed and simulated mean concentrations for the verification data set agree within a range from -0.003 to 0.28 milligram per liter (table 9). The calibration and verification simulations match the observed values well (fig. 9). The simulation profile of the verification data set for site 5 suggests SIG3 may be removing too much ammonia. Reducing the amount of ammonia removed by 10 percent would eliminate the zero concentrations in the 96-hour simulation period for the verification data set. However, no change was made because the model is not underpredicting total nitrogen, and the ammonia simulations are acceptable.

The model is considered calibrated and verified for nitrite. Rapid conversion of nitrite to nitrate is evident by the low nitrite concentrations throughout the study reach (fig. 10). The observed nitrite concentrations at the comparative data sites varied from a high range of 0.57 to 0.76 milligram per liter (site 3) to a low range of 0.045 to 0.066 milligram per liter (site 9) for the calibration data set and from a high range of 0.470 to 0.690 milligram per liter (site 3 ) to a low range of 0.062 to 0.098 milligram per liter (site 9) for the verification data set. Nitrite oxidation to nitrate occurs at about the same rate in Sand Creek until it is diluted by Caddo Creek. Further oxidation of nitrite is minimal in the remainder of Caddo Creek. Maximum oxidation rates (BET2 $=2.00$ per day) are used in the Sand Creek subreach to convert nitrite to nitrate. Lower nitrite oxidation rates (BET2 $=0.20$ per day) are used in Caddo Creek. The observed and simulated mean concentrations for the calibration data set agree within a 

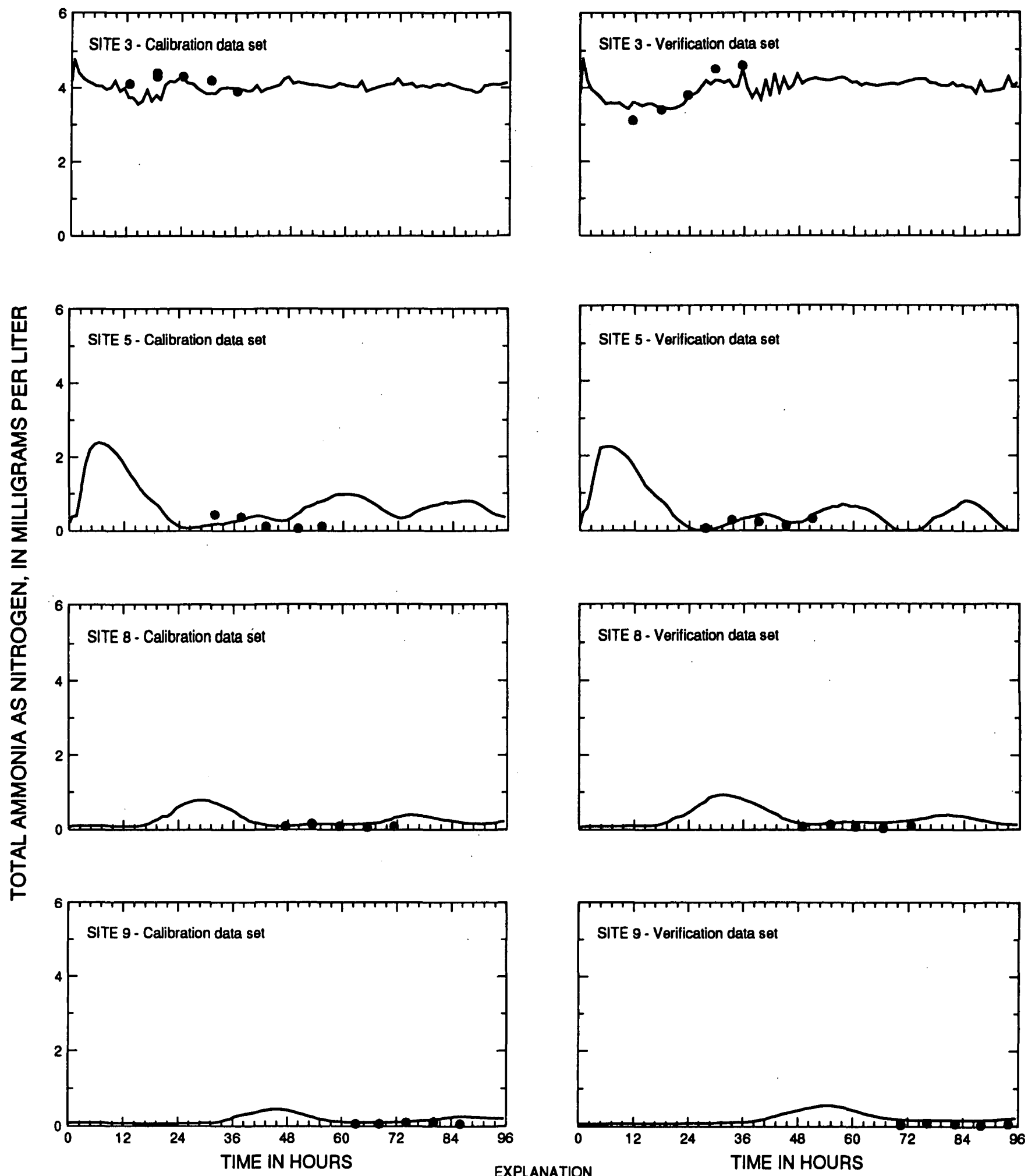

EXPLANATION

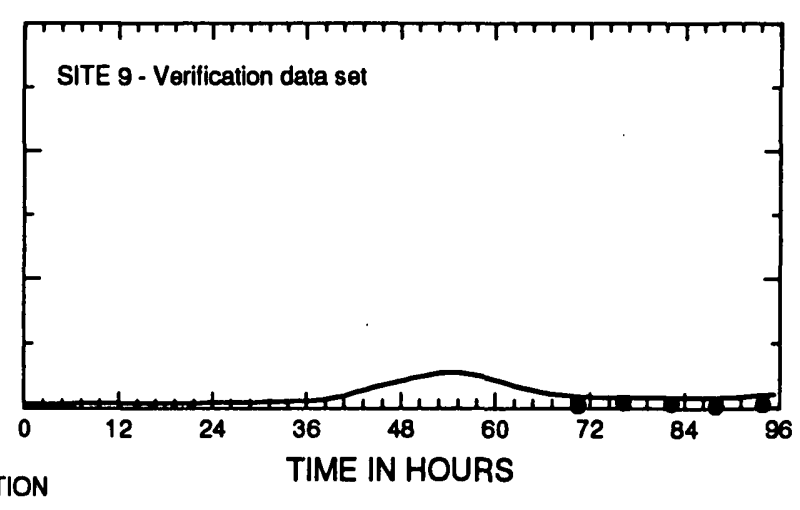

Simulated

- Observed

Figure 9. Simulated and observed total ammonia as nitrogen concentrations at sites 3 and 5 on Sand Creek near Ardmore, Oklahoma, and sites 8 and 9 on Caddo Creek near Gene Autry, Oklahoma, for calibration (July 29-August 1, 1997) and verification (August 26-29, 1997) data sets. 

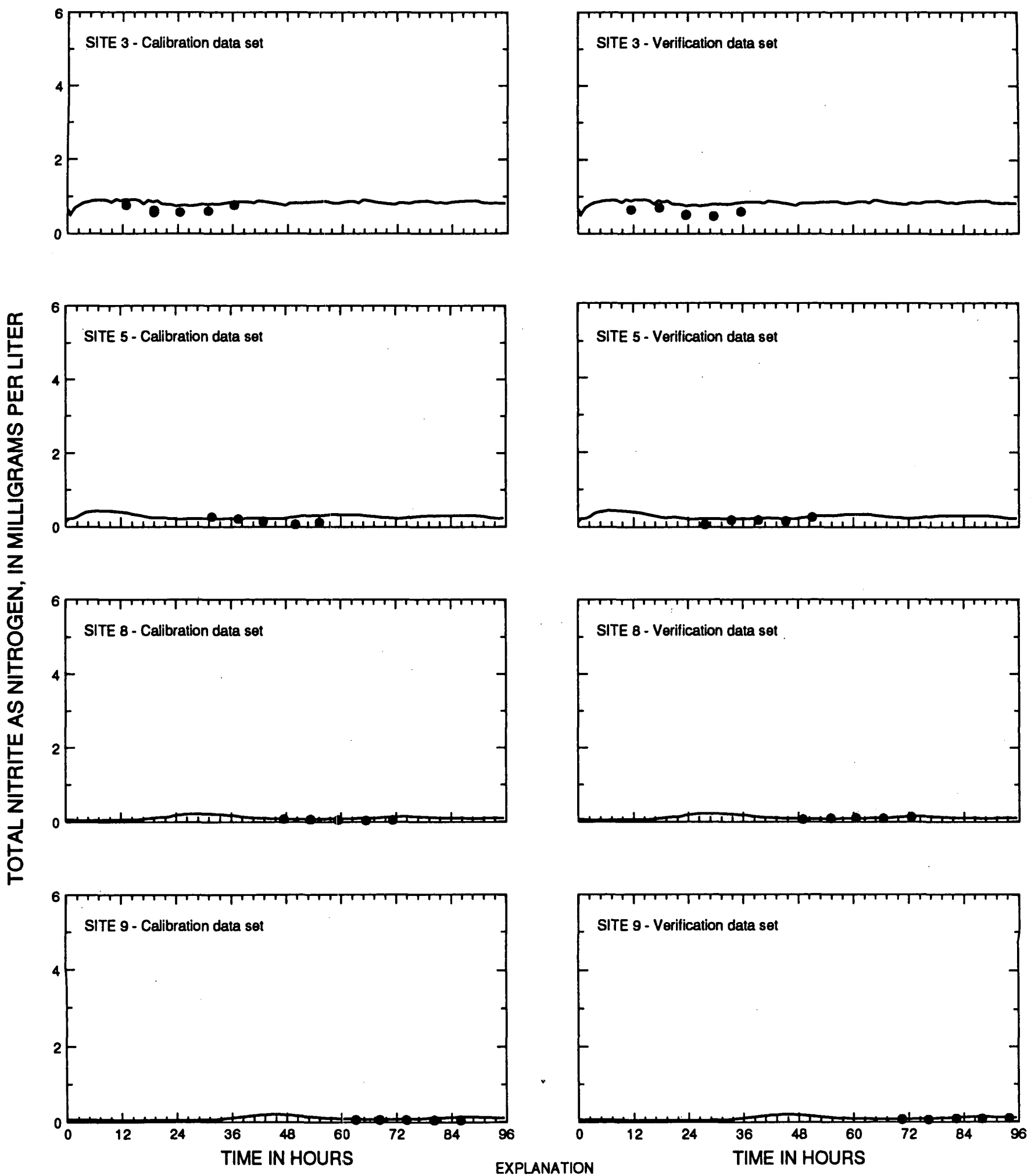

Simulated

- Observed

Figure 10. Simulated and observed total nitrite as nitrogen concentrations at sites 3 and 5 on Sand Creek near Ardmore, Oklahoma, and sites 8 and 9 on Caddo Creek near Ardmore, Oklahoma, for calibration (July 29-August 1, 1997) and verification (August 26-29, 1997) data sets. 
range from 0.04 to 0.21 milligrams per liter (table 8) The observed and simulated mean concentrations for the verification data set agree within a range from 0.027 to 0.18 milligram per liter (table 9). Both calibration and verification simulations match the observed values well (fig. 10).

The model is considered calibrated and verified for nitrate. The observed nitrate concentrations at the comparative data sites varied from a high range of 9.55 to 10.9 milligrams per liter (site 5) to a low range of 2.45 to 3.23 milligrams per liter (site 9) for the calibration data set and from a high range of 7.07 to 9.65 milligrams per liter (site 4) to a low range of 3.92 to 4.53 milligrams per liter (site 9) for the verification data set (fig. 11). The nitrate concentrations at site 3 are high (7.80 to 10.4 milligrams per liter for the calibration data set and 6.33 to 8.16 milligrams per liter for the verification data set) and are due to the high nitrate concentrations in the wastewater discharge from site 2. Because of nitrification, nitrate concentrations continue to increase in the remainder of Sand Creek. The nitrate concentrations are reduced about one-half after reaching Caddo Creek. In comparison, the observed data show that the nitrate concentrations decrease in Caddo Creek in the downstream direction. The downstream decrease in nitrate concentration is evident in both sets of observed data. The decrease in concentration may be due to uptake by algae or denitrification. Algal uptake of nitrate may be a factor in decreasing nitrate concentrations in Caddo Creek because of lower ammonia concentrations in Caddo Creek than in Sand Creek. Denitrification also may occur in the streambed sediments in Caddo Creek. The observed and simulated mean concentrations for the calibration data set agree within a range of 0.034 to 0.89 milligrams per liter (table 8). The observed and simulated mean concentrations for the verification data set agree within a range of 0.40 to 1.00 milligrams per liter (table 9). Both calibration and verification simulations tend to follow the observed values (fig. 11).

\section{Phosphorus}

The model is considered calibrated and verified for phosphorus. The calibration of phosphorus included both organic and hydrolyzable plus orthophosphorus as phosphorus (referred to as orthophosphorus). The observed organic phosphorus concentrations at the comparative data sites are small. The observed organic phosphorus concentrations varied from 0.01 to 0.10 milligram per liter for the calibration data set and from 0.01 to 0.60 milligram per liter for the verification data set (fig. 12). Both the calibration and verification simulations overpredict organic phosphorus (fig. 12). Organic phosphorous settling rates (SIG5) removed phosphorous from the water column. The maximum recommended settling rate of 0.100 per day is used in all subreaches to minimize the amount of organic phosphorous available to convert to orthophosphorus. It is necessary to use the maximum organic phosphorus decay rate (BET4) of 0.7 per day in subreach 1 to
2 and the minimum decay rate of 0.010 per day in the remaining subreaches.

The observed orthophosphorus concentrations range from a high of 2.5 to 2.8 milligrams per liter (site 3 ) to a low of 0.72 to 0.81 milligram per liter (site 9) for the calibration data set and from a high of 2.0 to 2.2 milligrams per liter (site 3 ) to a low of 1.0 to 1.1 milligrams per liter (site 9) for the verification data set (fig. 13). The orthophosphorus high range concentrations are at site 3 and are due to the high orthophosphorus concentrations in the wastewater discharge from site 2 . The orthophosphorus gradually decreases in the remainder of Sand Creek downstream from site 3. The concentrations are reduced about one-half after reaching Caddo Creek, then continue the gradual decrease in the remainder of Caddo Creek. This decreasing trend is evident in both data sets. The decrease in concentration may be due to uptake by algae. Observed orthophosphorus concentrations show a slight daily variation similar to daily nitrate variation. The orthophosphorus observed and simulated mean concentrations for the calibration data set agree within a range of -0.002 to 0.17 milligram per liter (table 8) and, for the verification data set, from -0.22 to 0.013 milligram per liter (table 9). The calibration and verification simulations match the observed data very well (fig. 13).

\section{Dissolved oxygen}

The model is considered calibrated and verified for dissolved oxygen under the conditions when samples were collected. The observed and simulated dissolved oxygen concentrations for the calibration and verification data sets are shown in figure 14. The maximum and minimum dissolved-oxygen concentration greatly differ in the study reach. The observed maximum dissolvedoxygen concentration at the comparative data sites was 11.7 milligrams per liter at site 8 and the minimum was 1.1 milligrams per liter at site 3 for the calibration data set. The observed maximum dissolved-oxygen concentration was 10.1 milligrams per liter at site 7 and the minimum was 0.8 milligram per liter at site 3 for the verification data set.

All sites show a daily variation in dissolved-oxygen concentration. The difference between the daily minimum and maximum dissolved-oxygen concentrations at all sites for the calibration data set varied within a range of 3.8 to 5.7 milligrams per liter except at site 3 where the variation was 2.0 milligrams per liter. Except for sites 3 and 4, the difference between the daily minimum and maximum dissolved-oxygen concentration for the verification data set varied within a range of 4.3 to 5.3 milligrams per liter.

The difference between the daily minimum and 

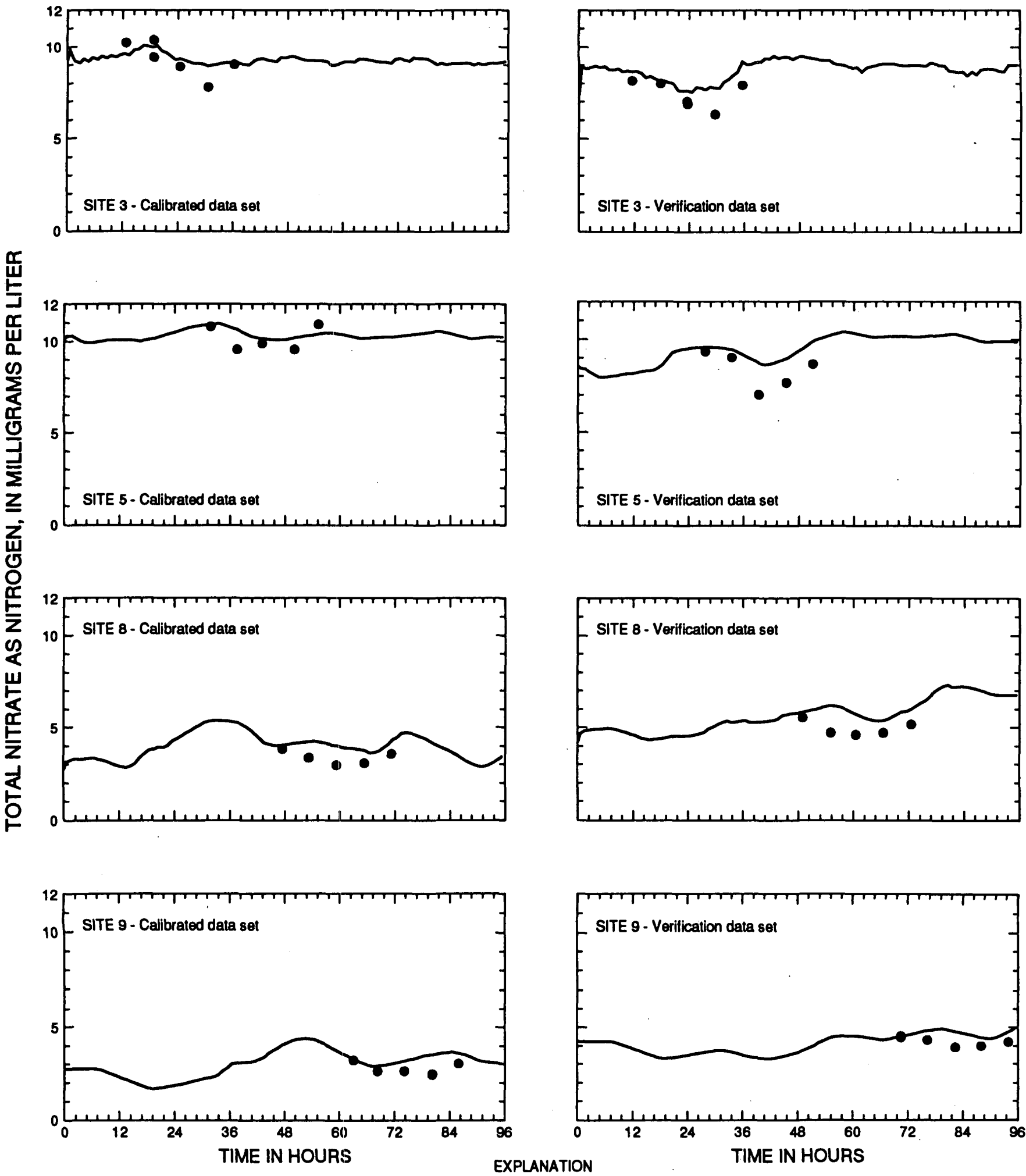

EXPLANATION

Simulated

- Observed

Figure 11. Simulated and observed total nitrate as nitrogen concentrations at sites 3 and 5 on Sand Creek near Ardmore, Oklahoma, and sites 8 and 9 on Caddo Creek near Gene Autry, OkJahoma, for calibration (July 29-August 1, 1997) and verification (August 26-29, 1997) data sets. 

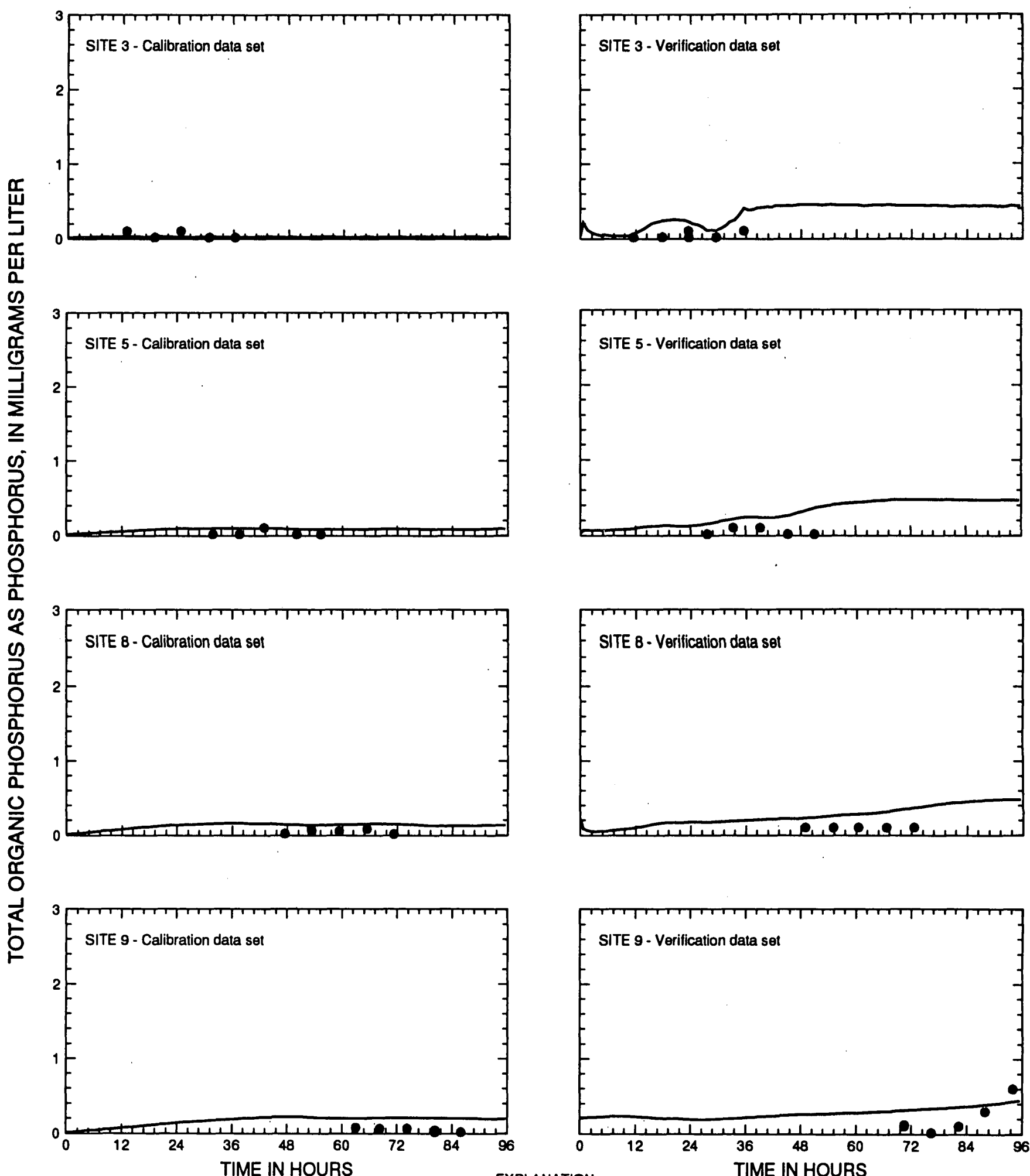

EXPLANATION

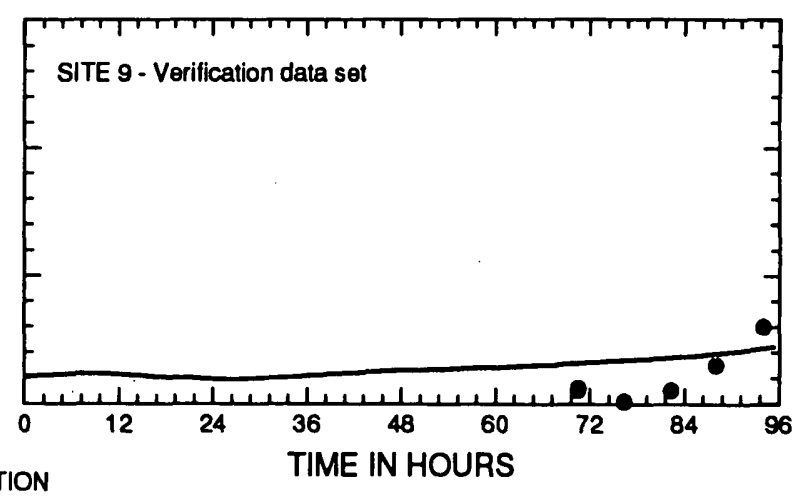

Simulated

- Observed

Figure 12. Simulated and observed total organic phosphorus as phosphorus concentrations at sites 3 and 5 on Sand Creek near Ardmore, Oklahoma, and sites 8 and 9 on Caddo Creek near Gene Autry, Oklahoma, for calibration (July 29-August 1, 1997) and verification (August 26-29, 1997) data sets. 


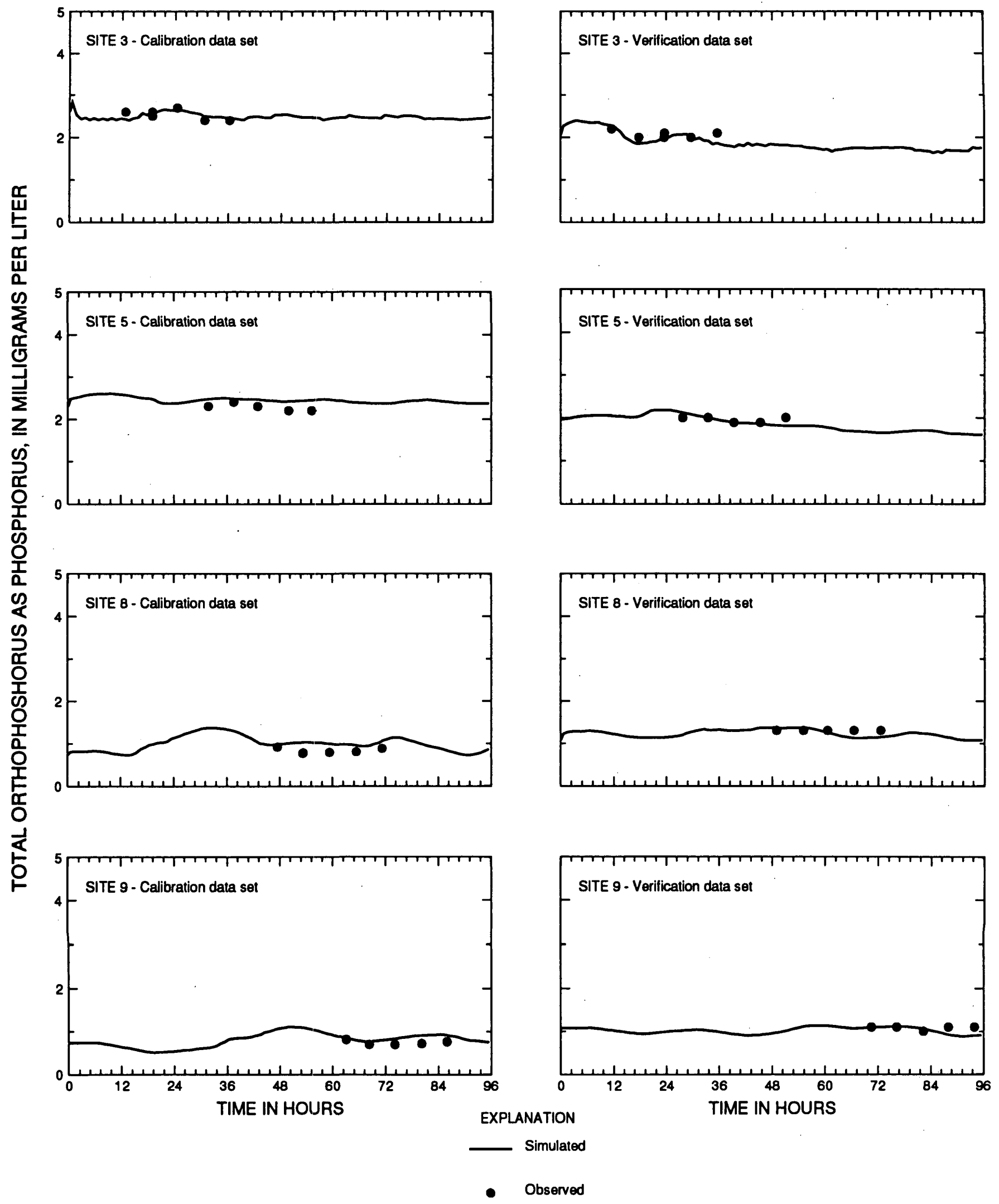

Figure 13. Simulated and observed total orthophosphorus as phosphorus concentrations at sites 3 and 5 on Sand Creek near Ardmore, Oklahoma, and sites 8 and 9 on Caddo Creek near Gene Autry, Oklahoma, for calibration (July 29-August 1, 1997) and verification (August 26-29, 1997) data sets. 

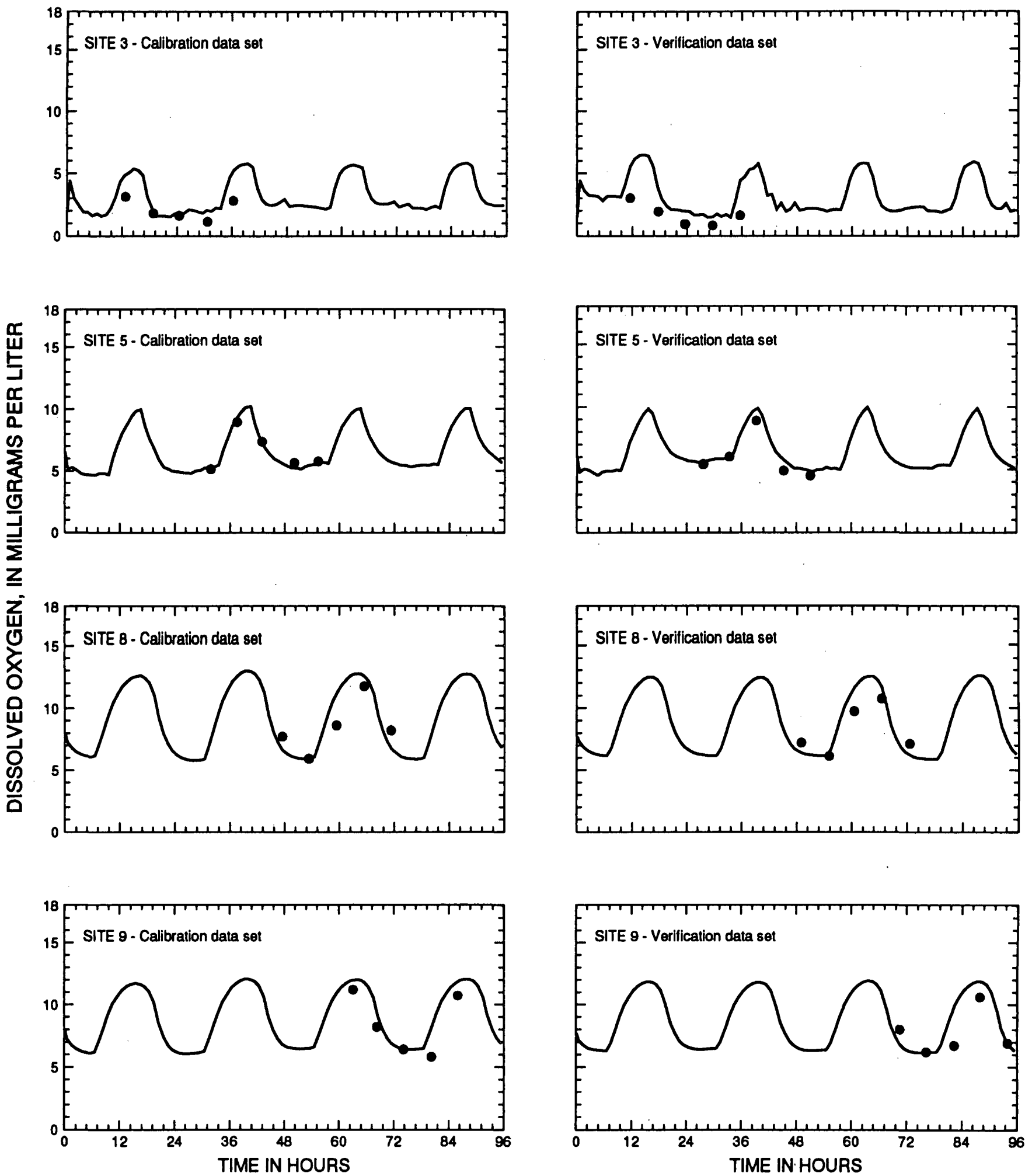

EXPLANATION

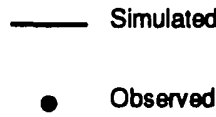

Figure 14. Simulated and observed dissolved oxygen concentrations at sites 3 and 5 on Sand Creek near Ardmore, Oklahoma, and sites 8 and 9 on Caddo Creek near Gene Autry, Oklahoma, for calibration (July 29-August 1, 1997) and verification (August 26-29, 1997) data sets. 
maximum dissolved oxygen for site 3 was 2.2 milligrams per liter and 2.9 milligrams per liter at site 4 .

The daily variations of dissolved-oxygen concentration are primarily due to algal photosynthesis. Algae produce oxygen during the day and are net consumers of oxygen during the night. The amount and duration of solar radiation affect photosynthesis. In Sand Creek and Caddo Creek, tree shading reduces the amount and duration of solar radiation. Therefore, the shapes of the dissolved-oxygen concentrations versus time profiles are affected by shading (fig. 14).

The saturated dissolved-oxygen concentration during the synoptic sampling was about 7.7 milligrams per liter (when water temperalure was 28.0 degrees Celsius and barometric pressure was $\mathbf{7 5 0}$ millimeters of mercury). Dissolved-oxygen concentrations above saturation are the result of photosynthesis. Dissolved-oxygen concentrations less than saturation are the result of biogradation of carbonaceous and nitrogenous waste discharged to the creek and algal respiration, both processes use oxygen.

The observed and simulated mean concentrations agree within a range from -0.004 to 1.32 milligrams per liter for the calibration data set (table 8) and from 0.17 to 1.65 for the verification data set (table 9). The simulated dissolved oxygen and the observed concentrations match well. The simulated dissolved oxygen peak concentrations for the sites shown in figure 14 exceed the observed dissolved oxygen peak concentrations. The dissolved-oxygen sampling frequency was 6 hours, and, in some cases, it is possible that the peak dissolved-oxygen concentration was not measured. In those cases, the higher simulated peak may be justified. However, at site 3 , the global settings for some reaction coefficients did not allow the flexibility needed to match the observed dissolved-oxygen concentration without taking the reaeration coefficient outside the estimated range.

The global algal reaction coefficients were set by trial and error during an initial calibration phase of various subreaches to determine which setting would give the best simulations for both Sand and Caddo Creek conditions. The maximum specific algal growth rate $(G R O=3.0)$ and algal respiration rate (RSPRT $=0.5$ ) were used to attain the maximum daily oxygen concentration swing. It would have been more appropriate in some subreaches to use less than maximum algal growth rate and algal respiration rate; this was not possible because of the global setting. In these instances, the reaeration coefficient (CK2), which can be adjusted by subreach, had to be reduced to reduce the minimum dissolved-oxygen concentration. However, in no subreach was the reaeration coefficient reduced below the estimated minimum. Generally, the periphyton concentration defines the maximum dissolved-oxygen concentration, and the reaeration coefficient defines the minimum dissolved-oxygen concentration.

Generally, the reaeration coefficient has the most effect on dissolved-oxygen simulations. In this study, periphyton concentrations and algal reaction coefficients also are important calibration parameters for dissolved oxygen. Simulation of photosynthetic production and respiratory consumption of dissolved oxygen by periphyton was essential to reproduce the observed daily variation. The reaeration coefficient and periphyton concentrations can be applied locally (by subreach). Other algal reaction coefficients that affect dissolved-oxygen concentration are applied globally (by study reach). The calibration of the local algal reaction coefficients followed calibration of the global algal reaction coefficients.

The reaeration coefficient was calibrated simultaneously with the periphyton-concentration calibration. The calibrated reaeration coefficient ranges from 5 to 6 per day in Sand Creek and is 7.5 per day in Caddo Creek. The calibrated reaeration coefficients are within the range estimated from the tracer study (table 5). Larger periphyton concentrations were observed in Sand Creek than in Caddo Creek. Periphyton concentrations in Sand Creek ranged from 385 to 1,565 milligrams of chlorophyll-a per square foot, and concentrations in Caddo Creek ranged from 131 to 307 milligrams of chlorophyll-a per square foot. For calibration, periphyton concentrations in Sand Creek were set to 20 milligrams of chlorophyll-a per square foot (about 1.5 percent of the mean periphyton concentration), and concentrations in Caddo Creek were set to 50 milligrams of chlorophyll-a per square foot (about 21 percent of the mean periphyton concentration) except for the last subreach where the concentration was reduced to 30 milligrams of chlorophyll-a per square foot (about 12 percent). The calibrated periphyton concentrations have an inverse relation to the observed periphyton concentrations. The larger calibrated periphyton concentrations are required in Caddo Creek to simulate supersaturated dissolved-oxygen concentrations. The smaller calibrated periphyton concentrations compared to the observed periphyton concentrations are an indication that the medium used to collect periphyton was more favorable to periphyton growth than the creek bed.

Both observed data sets and both the calibrated and verified simulations show the dissolved-oxygen concentration drops below 2 milligrams per liter for several hours in a 24-hour period at site 3 (fig. 14). Profiles of dissolved-oxygen concentrations at 3 p.m. and midnight were simulated to illustrate spatial relations and locate DO sag. The 3 p.m. and midnight profiles represent about maximum and minimum dissolved-oxygen concentrations during the first 24 hours of the 96-hour model run. 
The dissolved-oxygen concentration sag occurred in Sand Creek near site 3. Profiles of simulated dissolved-oxygen concentrations versus distance at 3 p.m. and at midnight are illustrated in figure 15. The figure.also shows ranges of observed dissolved-oxygen concentrations that were collected for the calibration data set, except for sites $3 \mathrm{~A}$ and 3B. At sites 3A and 3B the dissolved-oxygen concentration data were collected at the time the verification data set was collected. Dissolved-oxygen recovery begins near site 3 for both the 3 p.m. and midnight profiles. Two dissolved-oxygen monitors were located at sites $3 \mathrm{~A}$ and $3 \mathrm{~B}$ (fig. 1) to confirm the location of the minimum concentration dissolved-oxygen sag during the synoptic sampling (verification data set). The observed dissolved-oxygen minimum concentrations at both sites were larger than at site 3 . Dissolved-oxygen minimum concentrations are above 2 milligrams per liter at site 4 . Dissolved-oxygen recovery continues, and the minimum concentrations at site 5 are greater than 5 milligrams per liter. Simulated and observed dissolved-oxygen concentrations exceeded 5 milligrams per liter at all sites in Caddo Creek.

The major difference between the $3 \mathrm{p} . \mathrm{m}$. and midnight profiles is the result of algal (periphyton) activity. The 3 p.m. profile represents the approximate time of maximum algal photosynthesis (oxygen production). The 3 p.m. profile shows a decrease in dissolved-oxygen concentration at the confluence, because the Sand Creek streamflow is supersaturated due to photosynthesis and exceeds the dissolvedoxygen concentration in upstream Caddo Creek. The midnight profile represents the approximate time of minimum photosynthesis and shows, at site 7, the remnant of the dissolved-oxygen sag that had occurred earlier near site 3 . The remnant of the dissolved-oxygen sag shows at site 7 at midnight because the traveltime from site 3 to site 7 was roughly 24 hours after simulation began.

Excess nutrients in Sand Creek and Caddo Creek below the confluence stimulate algal growth, resulting in large daily variation in dissolved-oxygen concentration. Caddo Creek upstream from the confluence contains low concentrations of algae that cause relatively small daily variation in the dissolved-oxygen concentrations. Therefore, most of the dissolved-oxygen concentration variation at the confluence is due to algal activity in Sand Creek.

\section{Phytoplankton}

The model is not considered calibrated and verified for phytoplankton simulation. The observed and simulated calibration and verification data sets for phytoplankton as concentrations are shown in figure 16 . The observed concentration at comparative data sites range from a high of 3.20 to 29.0 micrograms per liter (site 9) to a low of 1.10 to 3.20 micrograms per liter (site 3 ) for the calibration data set. The extreme variability of the calibration data set is due to an algal bloom that formed at the time the observed calibration data set was collected. Except site 3, during certain daylight hours, the algal bloom increased the concen- trations about five to eight times. The observed phytoplankton concentrations range from a high of 8.50 to 15.0 micrograms per liter (site 8 ) to a low of 0.60 to 8.00 micrograms per liter (site 7) for the verification data set. The observed phytoplankton concentrations are less variable in the verification data set. Observed concentrations show no trend in either Sand or Caddo Creek. The simulated concentrations for the calibrated data set generally underpredict the concentrations except for site 3. The observed and simulated mean concentrations agree within a range from -13.5 to 1.80 micrograms per liter (table 8) for the calibration data set. Part of this wide range in the calibration data set is due to the wide scatter in the observed data. The observed and simulated mean concentrations agree within a range from -4.52 to -0.47 microgram per liter (table 9) for the verification data set. The simulated concentrations for the verification data set are more representative of the observed data (fig. 16).

\section{Summary and conclusions}

Sand Creek, a tributary to Caddo Creek, receives treated wastewater from a petroleum refinery and from the city of Ardmore, Oklahoma. Sand Creek is an ephemeral stream. Between precipitation events when streamflow rises and falls sharply, streamflow in Sand Creek is maintained by treated wastewater and by ground-water seepage. A 5.88-mile subreach on Sand Creek and a 14.58-mile subreach on Caddo Creek constitute a study area where data were collected to calibrate and verify a streamflow and water-quality model. The subreaches modeled were 5.86 miles on Sand Creek and 8.14 miles on Caddo Creek. The purpose of the model is to simulate streamflow and water-quality conditions during low streamflow when effects of wastewater discharge to the creeks are most severe. The water-quality constituent of most interest is dissolved oxygen because of water-quality standards.

The Caddo Creek drainage basin is 352 square miles, and the average gradient of Caddo Creek is about 7 feet per mile. The Sand Creek drainage basin is 13.3 square miles, and the average gradient of Sand Creek is about 15 feet per mile. Caddo Creek and Sand Creek are characterized by pools and riffles. Generally, at low streamflow, Caddo Creek is wider and shallower and has higher velocities than Sand Creek. At streamflows less than 20 cubic feet per second, Caddo Creek channel widths range from about 20 to 40 feet, and depths range from less than 1 to 2 feet except in pools. At streamflows less than 10 cubic feet per second, Sand Creek channel widths range from less than 10 feet to about 15 feet, and depths range from 1 to less than 3 feet except in pools. 


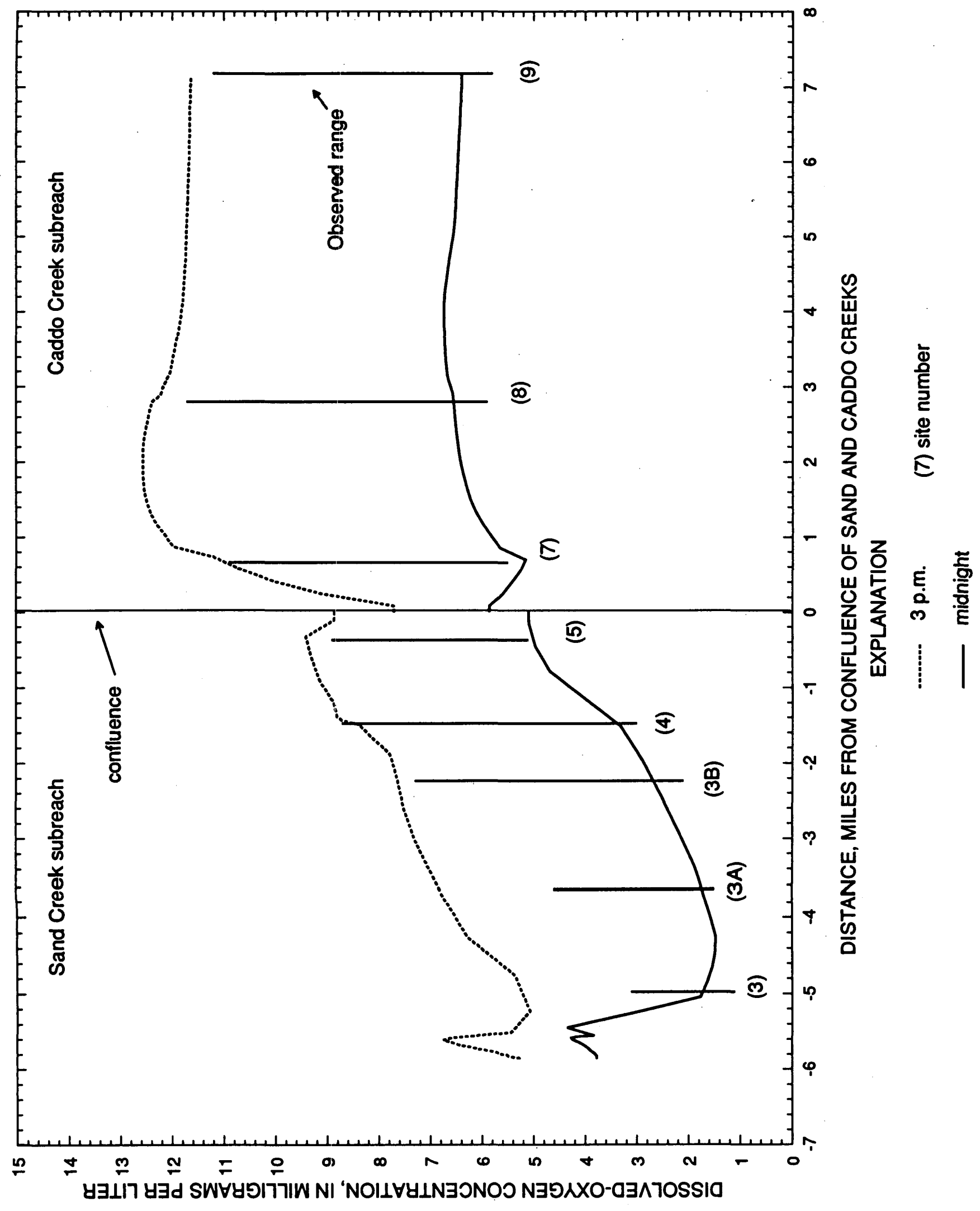




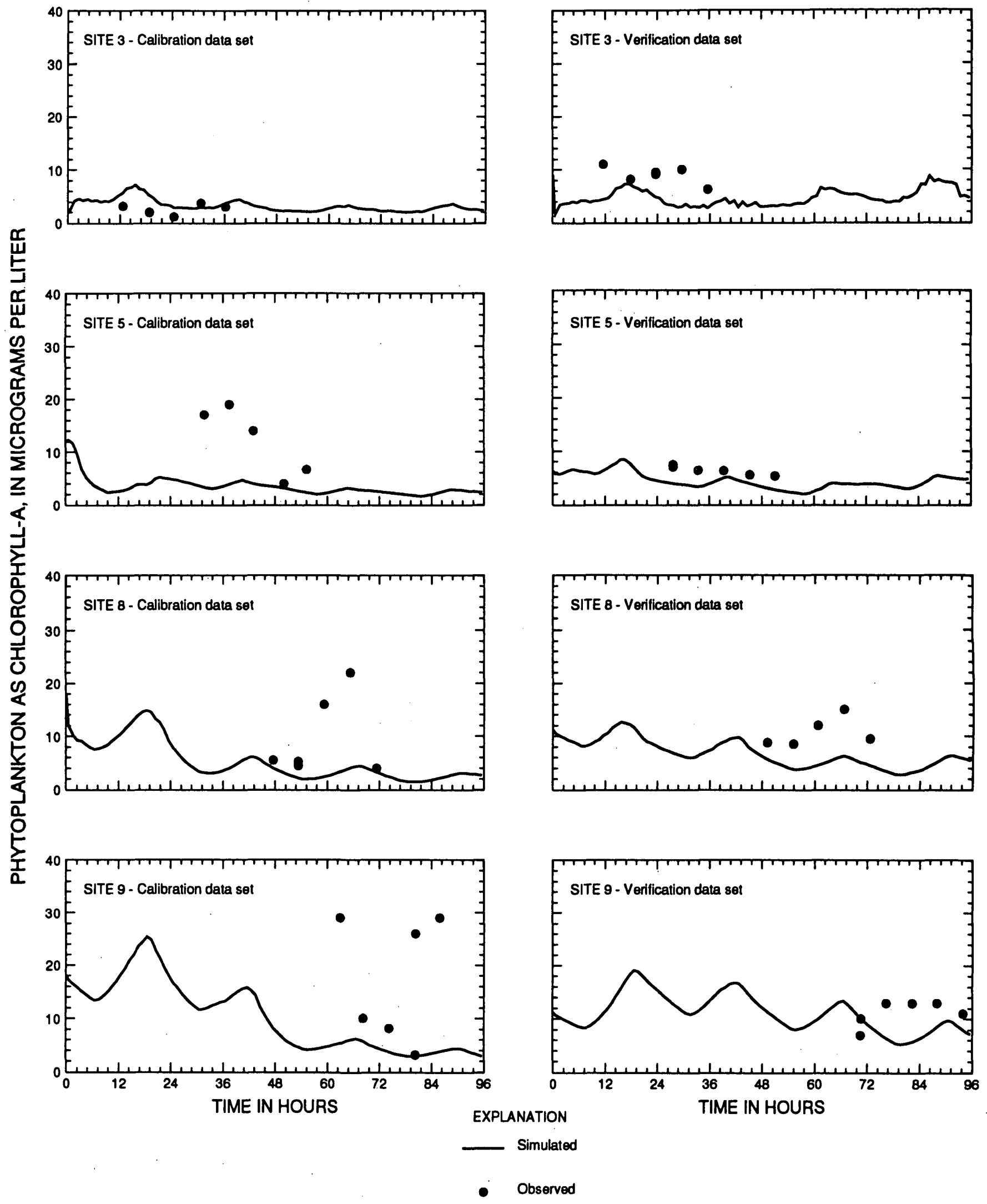

Figure 16. Simulated and observed phytoplankton concentrations at sites 3 and 5 on Sand Creek near Ardmore, Oklahoma, and sites 8 and 9 on Caddo Creek near Gene Autry, Oklahoma, for calibration (July 29-August 1, 1997) and verification (August 26-29, 1997) data sets. 
Sand Creek and, to a lesser extent, Caddo Creek has varying densities of submerged algal macrophytes rooted to the streambed.

Data collected to calibrate and verify the streamflow and water-quality model include continuously monitored streamflow and water-quality data at two gaging stations and three monitoring stations; wastewater discharge from two wastewater plants; two sets each of five water-quality samples at nine sites during a 24-hour period; dye and propane samples periphyton algal samples; and sediment oxygen demand measurements. The water-quality sampling, at a 6-hour frequency, was based on a Lagrangian reference frame in which the same volume of water was sampled at each site.

A transport modeling system was used that included both a model to route streamflow and a model to transport dissolved conservative constituents and links to a subroutine that applied reaction kinetics similar to the Environmental Protection Agency water-quality model to handle nonconservative constituents. The Ardmore Water-Quality Model was calibrated and verified with several data sets for streamflow and transport when streamflow ranged from 16 to 3,456 cubic feet per second. The water-quality reaction coefficients were calibrated when streamflows in Caddo Creek ranged from 8.4 to 20 cubic feet per second, of which 5.0 to 9.7 cubic feet per second was contributed by Sand Creek.

Because each creek had different tree-shading characteristics that affect algal photosynthesis, the Ardmore Water-Quality Model contains a modification to accept two solar radiation values one for Sand Creek and one for Caddo Creek. An important calibration parameter for dissolved oxygen in addition to the reaeration coefficient was periphyton concentrations. Simulation of photosynthetic production and respiratory consumption of dissolved oxygen by periphyton was essential to reproduce the observed daily variation. The calibrated reaeration coefficient ranges from 5 to 6 per day in Sand Creek and is 7.5 per day in Caddo Creek. Periphyton concentrations in Sand Creek were set to 20 milligrams per square foot and in Caddo Creek were set to 50 milligrams per square foot. The larger calibrated periphyton concentrations are required in Caddo Creek to simulate supersaturated dissolved-oxygen concentrations.

Of the 10 constituents for which the Ardmore Water-Quality Model was calibrated, 9 were verified: water temperature, 20-day carbonaceous biochemical oxygen demand, total organic nitrogen as nitrogen, total ammonia as nitrogen, total nitrite as nitrogen, total nitrate as nitrogen, total organic phosphorus as phosphorus, total hydrolyzable plus orthophosphorus as phosphorus, and dissolved oxygen. Phytoplankton were not verified. Only the calibrated reaction coefficient for organic nitrogen settling rate was outside of the recommended range. The benthic ammonia reaction coefficient was used as both a source and a sink.

The largest decrease in observed concentration of 20-day carbonaceous biochemical oxygen demand (6.6 milligrams per liter mean value) occurs in subreach 3 to 4 . The concentrations decrease at a slower rate for the remainder of Sand Creek. After being diluted by Caddo Creek, the concentrations show only a small decrease except in subreach 7 to 8 , where both observed data sets show an increase in concentration. The source of this increase is unknown.

The observed organic-nitrogen concentrations decrease downstream in Sand Creek, are diluted by Caddo Creek, then increase slightly downstream from site 7 through site 9 . The decrease in observed concentration is due to settling and hydrolysis to ammonia. The downstream increase in observed concentration may be due to the resuspension of settled organic particulate material or the recycling of dead phytoplankton. The calibration settling values provided the necessary amount of organic nitrogen to hydrolyze to ammonia. The simulation profile of the verification data set suggests that the calibrated organic nitrogen settling rate may be too high. However, no change was made because the model is not underpredicting total nitrogen, and, on balance, the organic nitrogen simulations are acceptable.

A large decrease in ammonia concentrations occurs between sites 3 and 4 . A large part of the decrease probably is due to uptake by periphyton, because nitrification (the oxidation of ammonia to nitrite and nitrate) cannot account for the large decrease in concentration. The ammonia concentrations continue to decrease in Sand Creek downstream of site 4. Only minimal ammonia oxidation occurs in Caddo Creek to the end of the study reach after dilution by Caddo Creek. Rapid conversion of nitrite to nitrate is evident by the low nitrite concentrations throughout the study reach. Nitrite oxidation to nitrate occurs at about the same rate in Sand Creek until it is diluted by Caddo Creek. Further oxidation of nitrite is minimal in the remainder of Caddo Creek.

The nitrate concentrations at site 3 are high and are due to the high nitrate concentrations in the wastewater discharge from site 2. Because of nitrification, nitrate concentrations continue to increase in the remainder of Sand Creek. The nitrate concentrations are reduced about one-half after reaching Caddo Creek. In comparison, the observed data show that the nitrate concentrations decrease in Caddo Creek in the downstream direction. The downstream decrease in nitrate concentration is evident in both sets of observed data. The decrease in concentration may be due to uptake by algae or denitrification. Algal uptake of nitrate may be a factor in 
decreasing nitrate concentrations in Caddo Creek because of lower ammonia concentrations in Caddo Creek than in Sand Creek. Denitrification also may occur in the streambed sediments in Caddo Creek.

The observed organic phosphorus concentrations at the comparative data sites are small. Both the calibration and verification simulations overpredict organic phosphorus. Organic phosphorous settling rates removed phosphorous from the water column. The orthophosphorus high range concentrations are at site 3 and are due to the high orthophosphorus concentrations in the wastewater discharge from site 2 . The orthophosphorus gradually decreases in the remainder of Sand Creek downstream from site 3. The concentrations are reduced about one-half after reaching Caddo Creek, then continue the gradual decrease in the remainder of Caddo Creek. The decrease in concentration may be due to uptake by algae.

The daily maximum and minimum dissolved-oxygen concentration greatly differ in the study reach. The daily variations of dissolved-oxygen concentration are primarily due to algal photosynthesis. Dissolved-oxygen concentrations above saturation are the result of photosynthesis. Dissolved-oxygen concentrations less than saturation are the result of biodegradation of carbonaceous and nitrogenous waste discharged to the creek and algal respiration, both processes use oxygen.

Generally, the periphyton concentration defines the maximum dissolved-oxygen concentration, and the reaeration coefficient defines the minimum dissolved-oxygen concentration. In this study, periphyton concentrations and algal reaction coefficients also are important calibration parameters for dissolved oxygen. Simulation of photosynthetic production and respiratory consumption of dissolved oxygen by periphyton was essential to reproduce the observed daily variation.

The calibrated periphyton concentrations have an inverse relation to the observed periphyton concentrations. The larger calibrated periphyton concentrations are required in Caddo Creek to simulate supersaturated dissolved-oxygen concentrations.

Both observed data sets and both simulated data sets show the dissolved-oxygen concentration drops below 2 milligrams per liter for several hours in a 24-hour period at site 3. The dissolved-oxygen concentration sag occurred in Sand Creek near site 3. Dissolved-oxygen recovery begins near site 3 for both the 3 p.m. and midnight profiles. Dissolved-oxygen minimum concentrations are above 2 milligrams per liter at site 4 . Dissolved-oxygen recovery continues, and the minimum concentrations at site 5 are greater than 5 milligrams per liter. Simulated and observed dissolved-oxygen concentrations exceeded 5 milligrams per liter at all sites in Caddo Creek.

\section{SELECTED REFERENCES}

Boning, C.W., 1974, Generalization of stream travel rates and dispersion characteristics from time-of-travel measurements: Journal of Research of the U.S. Geological Survey, v. 2, no. 4, July-August 1974, p. 495-499.

Bowie, G.L., Mills, W.B., Porcella, D.B., Campbell, C.L., Pagenkopf, J.R., Rupp, G.L., Johnson, K.M., Chan, P.W.H., Gherini, S.A., and Chamberlin, C.E., 1985, Rates, constants, and kinetics formulation in surface water quality modeling (2d edition): U.S. Environmental Protection Agency, EPA/600/3-85/040, 455 p.

Boyle, J.M., and Spahr, N.E., 1985, Traveltime, longitudinal-dispersion, reaeration, and basin characteristics of the White River, Colorado and Utah: U.S. Geological Survey Water-Resources Investigations Report 85-4050, $53 \mathrm{p}$.

Brown, C.L., and Bamwell, T.O.Jr., 1987, The enhanced stream water quality models QUAL2E and QUAL2E-UNCAS Documentation and user manual: Athens, Georgia, U.S. Environmental Protection Agency, Environmental Research Laboratory, 189 p.

Bulak, J.S., Hurley, N.M., Jr., and Crane, J.S., 1993, Production, mortality, and transport of striped bass eggs in Congaree and Wateree Rivers: South Carolina, American Fisheries Society Symposium 14, p. 29-37.

California Water Resources Control Board, 1996, Methodology for flow and salinity estimates in the Sacramento-San Joaquin Delta and Suisun Marsh: Seventeenth annual progress report to the State Water Resources Control Board in accordance with Water Right Decision 1485 , Order 9, June, 37 p.

Doyle, W.H., Jr., Shearman, J.O., Stiltner, G.J., and Krug, W.R., 1983, A digital model for streamflow routing by convolution methods: U.S. Geological Survey Water Resources Investigation Report 83-4160, 130 p.

Drewes, P.A., and Conrads, P.A., 1995, Assimilative capacity of the Waccamaw River and the Atlantic Intracoastal Waterway near Myrtle Beach, South Carolina, 1989-92: U.S. Geological Survey Water-Resources Investigations Report 95-4111, 58 p.

Graf, J.B., 1995, Measured and predicted velocity and longitudinal dispersion at steady and unsteady flow, Colorado River, Glen Canyon Dam to Lake Mead: Water Resources Bulletin, American Water Resources Association, v. 31, no. 2, p. 265-281.

Graf, J.B., 1986, Traveltime and longitudinal dispersion in Illinois streams: U.S. Geological Survey Water-Supply Paper 2269, 65 p.

Henderson, F.M., 1966, Open channel flow: MacMillan Publishing Company, New York, 522 p.

Jobson, H.E., 1977, Thermal model for evaporation from open channels: 17th Congress of the International Association for Hydraulic Research Proceedings, Baden-Baden, Germany, v. 2, August 15-19, 1977, p. 95-102.

-1980 , Comment on "A new collocation method for the solution of the convection-dominated transport equation," by Pinder, G.E., and Shario, Allen, 1979, (in Water Resources Research, v. 15, no. 5, p. 1177-1182) Water Resources Research, v. 16, no. 6, p. 1135-1136. 
1985, Simulating unsteady transport of nitrogen, biochemical oxygen demand, and dissolved oxygen in the Chattahoochee River downstream from Atlanta, Georgia: U.S. Geological Survey Water-Supply Paper 2264, $36 \mathrm{p}$.

1989, Users manual for an open-channel streamflow model based on the diffusion analogy: U.S. Geological Survey Water Resources Investigation Report 89-4133, $73 \mathrm{p}$.

1997, Enhancements to the Branched Lagrangian Transport Modeling System: U.S. Geological Survey Water-Resources Investigation Report 97-4050, 57 p.

Jobson, H.E., and Schoellhamer, D.H., 1987, Users manual for a branched Lagrangian transport model: U.S. Geological Survey Water-Resources Investigation Report 87-4163, 80 p.

Kilpatrick, F.A., Wilson, J.F., Jr., 1989, Measurement of time of travel in streams by dye tracing: U.S. Geological Survey Techniques of Water-Resources Investigation, book 3, chap. A9, 27 p.

Kilpatrick, F.A., Rathbun, R.E., Yotsukura, N., Parker, G.W., and DeLong, L.L, 1989, Determination of stream reaeration coefficients by use of tracers: U.S. Geological Survey Techniques of Water Resources Investigations, book 3, chap. A18, 52 p.

Leopold, L.B., and Maddock, Thomas, Jr., 1953, The hydraulic geometry of stream channels and some physiographic implications: U.S. Geological Survey Professional Paper 252, $57 \mathrm{p}$.

Leopold, L.B., and Miller, J.P., 1956, Ephemeral streams--Hydraulic factors and their relation to the drainage net: U.S. Geological Survey Professional Paper 282-A, 36 p.

McQuivey, R.S., and Keefer, T.N., 1974, Simple method for predicting dispersion in streams: Journal of Environ- mental Engineering, American Society of Civil Engineers, v. 100 , no. EE4, p. $997-1011$.

Murphy, P.J., and Hicks, D.B., 1986, In-situ method for measuring sediment oxygen demand, in Hatcher, K.J., ed., Sediment oxygen demand--Processes, modeling, and measurement: 56th Annual Conference of the Water Pollution Control Feder., Athens, Georgia, University of Georgia, October 2-7, 1983, p. 307-322.

Oklahoma Water Resources Board, 1968, Appraisal of the water and related land resources of Oklahoma, Region Three, p. 26.

Schoellhamer, D.H., and Jobson, H.E., 1986, Programmers manual for a one-dimensional Lagrangian transport model: U.S. Geological Survey Water Resources Investigation Report 86-4144, $101 \mathrm{p}$.

Shelton, L.R., 1994, Field guide for collecting and processing stream-water samples for the national water-quality assessment program: U.S. Geological Survey Open-File Report 94-455, p. 42.

Smoot, J.L, 1987, Effect of streamflow conditions on gas-transfer coefficients: Proceeding of the 1987 National Conference on Hydraulic Engineering, Hydraulic Division, American Society of Civil Engineers, August 3-7, 1987, p. 980-985.

Thomann, R.V., and Mueller, J.A., 1987, Principles of surface water quality modeling and control: New York, New York, Harper and Row, 644 p.

U.S. Department of Agriculture,1979, Soil survey of Carter County, Oklahoma: p. 1-2.

Wiley, J.B., 1993, Simulated flow and solute transport, and migration of a hypothetical soluble-contaminant spill for the New River in the New River Gorge National River, West Virginia: U.S. Geological Survey Water-Resources Investigations Report 93-4105, 39 p.

Wunderlich, W.O., 1972, Heat and mass transfer between a water surface and the atmosphere: Norris, Tennessee, Tennessee Valley Authority Water Resources Research Laboratory Report 14, $166 \mathrm{p}$. 


APPENDICES 

Appendix 1. Accumulative time since tracer injection and dye and propane concentrations for site 3 on Sand Creek and dye concentrations for sites 4 and 5 on Sand Creek and site 7 on Caddo Creek near Ardmore, Oklahoma

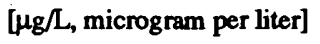

\begin{tabular}{|c|c|c|c|c|c|c|c|c|}
\hline \multicolumn{3}{|c|}{ Site 3} & \multicolumn{2}{|c|}{ Site 4} & \multicolumn{2}{|c|}{ Sito 5} & \multicolumn{2}{|c|}{ Sito 7} \\
\hline $\begin{array}{l}\text { Accumulative } \\
\text { time } \\
\text { (hours) }\end{array}$ & $\begin{array}{c}\text { Dye } \\
\text { concentration } \\
(\mu g / 1)\end{array}$ & $\begin{array}{c}\text { Propane } \\
\text { concentration } \\
(\mu \mathrm{g} / \mathrm{L})\end{array}$ & $\begin{array}{l}\text { Accumulative } \\
\text { time } \\
\text { (hours) }\end{array}$ & $\begin{array}{c}\text { Dye } \\
\text { concentration } \\
(\mu g / L)\end{array}$ & $\begin{array}{c}\text { Accumulative } \\
\text { time } \\
\text { (hours) }\end{array}$ & 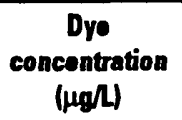 & $\begin{array}{c}\text { Accumulative } \\
\text { time } \\
\text { (hours) }\end{array}$ & $\begin{array}{c}\text { Dye } \\
\text { concentration } \\
(\mu g / 1)\end{array}$ \\
\hline \multicolumn{9}{|c|}{ Tracer was injected above site 2 on July 17, 1997, at 1500 hours } \\
\hline 17.08 & 0.00 & -- & 29.60 & 0.00 & 33.80 & 0.00 & 38.00 & 0.00 \\
\hline 17.17 & 0.90 & -- & 30.00 & 1.43 & 34.03 & 0.45 & 38.98 & 0.30 \\
\hline 17.22 & 2.60 & -- & 30.25 & 2.85 & 34.13 & 0.60 & 39.95 & 1.15 \\
\hline 17.25 & 4.30 & -- & 30.50 & 5.00 & 34.58 & 1.35 & 40.67 & 2.60 \\
\hline 17.32 & 7.00 & -- & 30.75 & 8.50 & 35.17 & 3.80 & 41.35 & 4.40 \\
\hline 17.40 & 12.80 & -- & 31.25 & 18.00 & 35.72 & 7.50 & 42.17 & 7.80 \\
\hline 17.45 & 18.50 & - & 31.75 & 25.00 & 35.97 & 9.90 & 42.63 & 8.50 \\
\hline 17.53 & 26.00 & 5.60 & 32.25 & 32.50 & 36.12 & 11.30 & 43.15 & 8.60 \\
\hline 17.58 & 31.00 & 7.35 & 32.75 & 37.00 & 36.38 & 14.40 & 43.65 & 8.00 \\
\hline 17.67 & 41.00 & 9.10 & 33.25 & 38.00 & 36.80 & 18.20 & 44.52 & 5.58 \\
\hline 17.83 & 66.00 & 22.05 & 33.75 & 37.00 & 37.10 & 21.80 & 45.50 & 3.10 \\
\hline 17.95 & 85.50 & 35.00 & 34.25 & 33.00 & 37.60 & 26.00 & 46.48 & 1.62 \\
\hline 18.03 & 94.50 & 36.00 & 34.75 & 28.50 & 38.15 & 29.00 & 47.50 & 0.98 \\
\hline 18.12 & 108.00 & 37.00 & 35.50 & 22.80 & 38.35 & 30.00 & 48.50 & 0.65 \\
\hline 18.20 & 120.00 & 42.50 & 36.00 & 19.00 & 38.65 & 31.50 & 49.50 & 0.50 \\
\hline 18.27 & 124.00 & 48.00 & 36.75 & 14.00 & 39.00 & 32.00 & 52.25 & 0.30 \\
\hline 18.33 & 124.00 & 44.00 & 37.75 & 8.50 & 39.60 & 30.00 & 54.00 & 0.22 \\
\hline 18.38 & 115.00 & 40.00 & 38.75 & 4.30 & 40.05 & 26.00 & 56.50 & 0.15 \\
\hline 18.43 & 109.00 & 36.00 & 40.00 & 2.20 & 40.80 & 18.00 & 58.50 & 0.00 \\
\hline 18.60 & 88.00 & 32.00 & 40.50 & 1.70 & 41.15 & 14.50 & - & - \\
\hline 18.77 & 75.00 & 26.50 & 41.00 & 1.40 & 41.88 & 10.20 & -- & - \\
\hline 19.10 & 53.00 & 21.00 & 42.00 & 1.05 & 42.12 & 8.00 & -. & - \\
\hline 19.60 & 26.00 & 11.90 & 43.00 & 0.70 & 42.93 & 5.10 & -- & - \\
\hline 20.10 & 11.00 & 2.80 & 43.93 & 0.32 & 43.63 & 3.40 & -- & - \\
\hline 20.82 & 4.10 & -- & 44.25 & 0.17 & 45.80 & 1.10 & -- & - \\
\hline 21.25 & 2.45 & -- & 45.00 & 0.00 & 49.95 & 0.80 & -- & - \\
\hline 21.80 & 0.00 & -. & - & -- & 50.98 & 0.75 & -- & - \\
\hline- & -- & - & - & -- & 51.47 & 0.73 & -- & - \\
\hline- & - & -. & - & -. & 52.10 & 0.63 & -. & - \\
\hline-- & - & -- & - & -- & 54.20 & 0.00 & -- & -- \\
\hline
\end{tabular}


Appendix 1. Accumulative time since tracer injection and dye and propane concentrations for site 7, and dye concentrations for sites 8 and 9 on Caddo Creek near Ardmore, Oklahoma - Continued

\begin{tabular}{|c|c|c|c|c|c|c|}
\hline \multicolumn{3}{|c|}{ Site 7} & \multicolumn{2}{|c|}{ Sito 8} & \multicolumn{2}{|c|}{ Sito 9} \\
\hline $\begin{array}{l}\text { Accumulativo } \\
\text { timo } \\
\text { (hours) }\end{array}$ & $\begin{array}{c}\text { Dyo } \\
\text { concentration } \\
(\mu g / L)\end{array}$ & $\begin{array}{l}\text { Propano } \\
\text { concentration } \\
(\mu g / 1)\end{array}$ & $\begin{array}{c}\text { Accumulativo } \\
\text { timo } \\
\text { (hours) }\end{array}$ & $\begin{array}{c}\text { Dyo } \\
\text { concontration } \\
(\mu g / L)\end{array}$ & $\begin{array}{l}\text { Accumulativo } \\
\text { time } \\
\text { (hours) }\end{array}$ & $\begin{array}{c}\text { Dyo } \\
\text { concentration } \\
(\mu g / l)\end{array}$ \\
\hline \multicolumn{7}{|c|}{ Tracer was injected at site 6 on July 16, 1997, at 0933 hours } \\
\hline 14.25 & 0.00 & -- & 22.30 & 0.00 & 34.90 & 0.00 \\
\hline 14.32 & 0.20 & .- & 22.60 & 0.75 & 35.00 & 0.05 \\
\hline 14.42 & 0.49 & - & 22.90 & 2.00 & 35.75 & 0.62 \\
\hline 14.58 & 1.40 & - & 23.30 & 4.60 & 36.00 & 0.98 \\
\hline 14.67 & 2.57 & - & 23.57 & 6.80 & 36.28 & 1.60 \\
\hline 14.75 & 3.85 & -- & 23.63 & 7.70 & 36.50 & 2.30 \\
\hline 14.83 & 5.90 & - & 23.92 & 10.40 & 36.73 & 3.20 \\
\hline 14.92 & 9.40 & -- & 24.15 & 12.00 & 36.92 & 3.85 \\
\hline 15.00 & 12.10 & 3.70 & 24.23 & 14.00 & 37.08 & 4.55 \\
\hline 15.08 & 14.20 & 5.15 & 24.33 & 15.00 & 37.25 & 5.20 \\
\hline 15.20 & 21.70 & 6.60 & 24.42 & 16.50 & 37.42 & 5.90 \\
\hline 15.28 & 25.00 & 8.30 & 24.53 & 18.00 & 37.58 & 7.40 \\
\hline 15.36 & 29.70 & 10.00 & 24.63 & 19.50 & 37.75 & 8.10 \\
\hline 15.50 & 38.50 & 13.00 & 24.75 & 21.00 & 38.08 & 10.00 \\
\hline 15.67 & 44.50 & 16.00 & 24.80 & 22.00 & 38.25 & 10.90 \\
\hline 15.83 & 52.00 & 16.50 & 24.88 & 23.00 & 38.42 & 11.50 \\
\hline 16.00 & 56.50 & 17.00 & 25.00 & 24.50 & 38.58 & 12.00 \\
\hline 16.17 & 54.50 & 17.00 & 25.18 & 27.40 & 38.92 & 13.20 \\
\hline 16.25 & 54.00 & 17.00 & 25.30 & 27.10 & 39.08 & 14.10 \\
\hline 16.50 & 50.00 & 14.00 & 25.40 & 26.90 & 39.25 & 14.50 \\
\hline 16.75 & 44.00 & 11.00 & 25.60 & 26.70 & 39.50 & 15.00 \\
\hline 17.08 & 30.00 & 7.20 & 25.70 & 26.50 & 39.75 & 15.25 \\
\hline 17.42 & 22.00 & 3.30 & 25.70 & 26.00 & 40.00 & 15.50 \\
\hline 17.75 & 13.50 & - & 26.25 & 23.00 & 40.25 & 15.50 \\
\hline 18.08 & 9.00 & -- & 26.62 & 20.00 & 40.52 & 15.00 \\
\hline 18.58 & 4.40 & - & 27.10 & 15.50 & 40.75 & 14.50 \\
\hline 19.08 & 2.05 & -- & 27.62 & 12.00 & 41.25 & 14.00 \\
\hline 19.50 & 1.60 & - & 28.10 & 8.90 & 42.00 & 12.00 \\
\hline 20.00 & 0.95 & -- & 28.62 & 5.80 & 43.00 & 8.90 \\
\hline 20.50 & 0.70 & - & 29.17 & 4.10 & 43.55 & 5.45 \\
\hline 21.00 & 0.35 & - & 29.60 & 3.20 & 44.98 & 3.85 \\
\hline 21.30 & 0.00 & - & 30.10 & 2.40 & 45.98 & 2.60 \\
\hline-- & - & - & 30.58 & 1.65 & 47.53 & 1.45 \\
\hline-- & - & - & 31.08 & 1.20 & 49.00 & 0.98 \\
\hline -- & -- & - & 31.62 & 0.90 & 51.00 & 0.58 \\
\hline -- & - & - & 32.00 & 0.75 & 53.30 & 0.30 \\
\hline -- & -- & - & 32.30 & 0.00 & 55.03 & 0.15 \\
\hline- & - & - & - & -- & 58.00 & 0.08 \\
\hline -- & -- & - & - & - & 58.30 & 0.00 \\
\hline
\end{tabular}


Appendix 2. Sediment oxygen demand at stream temperature and adjusted to 20 degrees Celsius for sites 3, 4, and 5 on Sand Creek near Ardmore, Oklahoma, and sites 6, 7, 8, and 9 on Caddo Creek near Gene Autry, Oklahoma, September 20-24, 1997

[SOD, sediment oxygen demand; $\mathrm{SOD}_{20}$, adjusted to $20^{\circ} \mathrm{C} ;\left[\left(\mathrm{mgO} / \mathrm{ft}^{2}\right) / \mathrm{d}\right]$, (milligrams oxygen per square foot) per (day); ${ }^{\circ} \mathrm{C}$, degrees $\mathrm{Celsius;}--$, no data]

\begin{tabular}{cccccc}
\hline Site & Date & $\begin{array}{c}\text { Timo } \\
\text { (hours) }\end{array}$ & $\begin{array}{c}\text { Temperature } \\
\left({ }^{\circ} \mathrm{C}\right)\end{array}$ & $\begin{array}{c}\text { SOD } \\
{\left[\left(\mathrm{mgOh}^{2} \text { ) d }\right]\right.}\end{array}$ & $\begin{array}{c}\text { SOD }_{20} \\
{\left[\left(\mathrm{mgOh}^{2} \text { )d }\right]\right.}\end{array}$ \\
\hline 3 & $9 / 22 / 97$ & $1520-1720$ & 28 & 87 & 55 \\
4 & $9 / 21 / 97$ & $1620-1840$ & 24 & 63 & 50 \\
5 & $9 / 23 / 97$ & $1445-1740$ & 25 & 19 & 14 \\
6 & $9 / 20 / 97$ & $1600-1915$ & 29 & 53 & 32 \\
7 & $9 / 20 / 97$ & $1020-1230$ & 26 & 93 & 66 \\
8 & $9 / 24 / 97$ & $1000-1200$ & 22 & 25 & 22 \\
9 & $9 / 22 / 97$ & $0940-1140$ & 23 & 72 & 60 \\
\hline
\end{tabular}


Appendix 3. Modifications to QUAL2E.f to include periphyton, multiple solar radiation data sets, and Smoot's reaeration equation

By Harvey E. Jobson, U.S. Geological Survey

Periphyton was considered to be a major factor in the nutrient and oxygen budgets of Sand Creek and the Caddo Creek. The QUAL2E.f kinetics subroutine for the BLTM was designed to mimic the reaction kinetics contained in the Environmental Protection Agency steady state water quality model QUAL2E. The QUAL2E model contains no mechanism to simulate periphyton and allows only a single solar radiation value for the entire modeling system.

Sand Creek has heavy bank vegetation that shades the water surface for much of the day, while Caddo Creek is much wider and more open, and receives more solar radiation. The BLTM/QUAL2E subroutine was therefore modified to expect two solar radiation values for each time step of the model instead of one. The added solar radiation values were supplied in the meteorological boundary conditions of the file "qual2e.in" as another column following the usual solar radiation values. The solar radiation values applicable to Sand Creek were placed in the first column and the values applicable to Caddo Creek were placed in the second column. The code was modified to use the first column of solar radiation values if coefficients for branch 1 (Sand Creek) were being computed and to use the values in the second column if either branch 2 or 3 (Caddo Creek) were being computed.

All solar radiation values were computed by a program called solar.f that computes the values based on solar time, day of the year, latitude, longitude, sunshine duration for the day, elevation of the site, the altitude of the sunrise and sunset horizons, and dew point temperature. The theory upon which the program is based has been presented by Wunderlich (1972) and is summarized by Jobson (1997). In order to account for the added shading on Sand Creek the altitude of sunrise and sunset were set at 45 degrees, rather than zero as assumed for Caddo Creek. This resulted in the apparent sunrise or sunset occurring on Sand Creek about 3 hours later or earlier (respectively) than on the Caddo Creek. The total daily solar radiation on Sand Creek averaged about 64 percent of that on Caddo Creek.

The QUAL2E model allows a choice between one of eight options for suppling the reaeration coefficient and it allows for the input of up to three parameters in each subreach to be used in computing the coefficient. One of these parameters $(\mathrm{CB}(\mathrm{N}, \mathrm{I}))$ is used only when the reaeration coefficient is to be computed by use of a power function (option 7). Because the power function option was not to be used here, the definition of the coefficient $(\mathrm{CB}(\mathrm{N}, \mathrm{I}))$ was changed from an exponent in the reaeration equation to periphyton per square foot of bed, in micrograms chlorophyll-a per square foot. This allowed the user to input a periphyton quantity for each subreach of the system.

In order to approximately represent the effect of periphyton on the constituent budgets, the quantity of periphyton was converted to an effective concentration in the overlying water by dividing by the depth. The periphyton concentration was then assumed to represent a bed-source term for organic nitrogen, ammonia, nitrate, organic phosphorus, and dissolved oxygen, with a magnitude proportional to the growth and respiration rates determined for phytoplankton. So the periphyton consumed and produced nutrients and oxygen at a rate proportional to its apparent concentration and the availability of light and nutrients, but the actual periphyton concentration remained constant and did not change as a result of this growth or respiration. The BLTM is set up to compute changes in concentrations only for dissolved constituents, not constituents associated with the bed.

It also was believed that an reaeration equation developed by Smoot (1987) would better represent the reaeration coefficients in this system than the equations available in the QUAL2E model. So the power law option (option 7) was removed from the code and replaced with the Smoot equation:

$$
\mathrm{K}_{2}=683.82\left(\mathrm{ABS}(\mathrm{V})^{0.5325}\right)\left(\mathrm{S}^{0.6236}\right) / \mathrm{D}^{0.7258}
$$

in which $\mathrm{K} 2$ = reaeration coefficient, in per day; $\mathrm{ABS}=$ absolute value in relation to stream velocity; $\mathrm{V}=$ stream velocity in cubic feet per second; $S=$ bed slope; and $D=$ stream depth, in feet. Stream velocity and depth were computed intemally but the stream slope had to be supplied as input data. This was accomplished by adding it to the input stream as the coefficient $\mathrm{CK} 2(\mathrm{~N}, \mathrm{I})$ in "qual2e.in." This variable is not used for options $2,3,4$, or 6 , but is defined as the reaeration coefficient for option 1, and as Mannings $\mathrm{n}$ for option 5 or 8 . 
This section contains an introduction to the methods and terminology used in collecting continuous long-term and short-term water discharge and water-quality records. The data collection description in this section pertains to continuous record collection. Noncontinuous data collection methods, such as synoptic sampling, are described within the body of the report.

\section{Station Identification Numbers}

Each data station in this report is assigned a unique identification number. This number is unique in that it applies specifically to a given station and to no other. The number usually is assigned when a station is first established and is retained for that station indefinitely. The system used by the U.S. Geological Survey to assign identification numbers for surface-water stations is based on geographic location. The "downstream order" system is used for regular surface-water stations.

\section{Downstroam Order System}

Since Oct. 1, 1950, the order of listing hydrologic-station records in Survey reports is in a downstream direction along the main stream. All stations on a tributary entering upstream from a mainstream station are listed before that station. A station on a tributary that enters between two mainstream stations is listed between them.

The station-identification number is assigned according to downstream order. In assigning station numbers, no distinction is made between partial-record stations and other stations; therefore, the station number for a partial-record station indicates downstream-order position in a list made up of both types of stations. Gaps are left in the series of numbers to allow for new stations that may be established; hence, the numbers are not consecutive. The complete number for each station, such as 07152500 , which appears just to the left of the station name, includes the two-digit Part number "07" plus the up to 13-digit downstream-order number " 152500 ." The Part number designates the major river basin; for example, part " 07 " is the Lower Mississippi River basin.

\section{Data Collection and Computation}

Continuous records of stage are obtained with analog recorders that trace continuous graphs of stage or with digital recorders that punch stage values on paper tapes at selected time intervals or with electronic data loggers. Measurements of discharge are made with current meters using methods adapted by the Geological Survey as a result of experience accumulated since 1880 . These methods are described in standard textbooks, in Water-Supply Paper 2175, and in U.S. Geological Survey Techniques of Water-Resources Investigations, Book 3, Chapter A1 through A19 and Book 8, Chapters A2 and B2. The methods are consistent with the American Society for Testing and Materials (ASTM) standards and generally follow the standards of the International Organization for Standards (ISO).

In computing discharge records, results of individual measurements are plotted against the corresponding stages, and stage-discharge relation curves are then constructed. From these curves, rating tables indicating the approximate discharge for any stage within the range of the measurements are prepared. It is necessary to define extremes of discharge outside the range of the current-meter measurements, the curves are extended using: (1) logarithmic plotting; (2) velocity-area studies; (3) results of indirect measurements of peak discharge, such as slope-area or contracted-opening measurements, and computations of flow-over-dams or weirs; or (4) step-backwater techniques.

Daily mean discharges are computed by applying the daily mean stages (gage heights) to the stage-discharge curves or tables. If the stage-discharge relation is subject to change because of frequent or continual change in the physical features that form the control, the daily mean discharge is determined by the shifting-control method, in which correction factors based on the individual discharge measurements and notes of the personnel making the measurements are applied to the gage heights before the discharges are determined from the curves or tables. This shifting-control method also is used if the stage-discharge relation is changed temporarily because of aquatic growth or debris on the control.

\section{Data Presentation}

The records published for each continuous-record surface-water discharge station (gaging station) consist of five parts, the manuscript or station description; the data table of daily mean values of discharge for the current water year with summary data; a tabular statistical summary of monthly mean flow data for a designated period, by water year, a summary statistics table that includes statistical data of annual daily, and instantaneous flows as well as data pertaining to annual runoff, 7-day low-flow minimums, and flow duration; and a hydrograph 


\section{Station Manuscript}

The manuscript provides, under various headings, descriptive information, such as station location; period of record; historical extremes outside the period of record; record accuracy; and other remarks pertinent to station operation and regulation. The following information as appropriate, is provided with each continuous record of discharge or lake content. Comments to follow clarify information presented under the various headings of the station description.

LOCATION.--Information on locations is obtained from the most accurate maps available. The location of the gage with respect to nearby cultural and physical features and with respect to the reference place mentioned in the station name is given. River mileages, given for most stations, were determined by methods given in "River Mileage Measurement," Bulletin 14, Revision of October 1968, prepared by the Water Resources Council or were provided by the U.S. Army Corps of Engineers.

DRAINAGE AREA.--Drainage areas are measured using the most accurate maps available. Because the type of maps available varies from one drainage basin to another, the accuracy of drainage areas likewise varies. Drainage areas are updated as better maps become available.

PERIOD OF RECORD.--This indicates the period for which there are published records for the station or for an equivalent station. An equivalent station is one that was in operation at a time that the present station was not, and whose location was such that records from it can reasonably be considered equivalent with records from the present station.

GAGE.--The type of gage in current use, the datum of the current gage referred to sea level (see Definitions of Terms), and a condensed history of the types, locations, and datums of previous gages are given under this heading.

REMARKS.--All periods of estimated daily discharge will either be identified by date in this paragraph of the station description for: water-discharge stations or flagged in the daily discharge table. (See next section, "Identifying Estimated Discharge.") If a REMARKS paragraph is used to identify estimated record, the paragraph will begin with this information presented as the first entry. The paragraph also is used to present information relative to the accuracy of the records, to special methods of computation, and to conditions that affect natural flow at the station. In addition, information may be presented pertaining to average discharge data for the period of record; to extremes data for the period of record and the current year, and possibly, to other pertinent items. For reservoir stations, information is given on the dam forming the reservoir, the capacity, outlet works and spillway, and purpose and use of the reservoir.

\section{Data Table of Daily Mean Values}

The daily table of discharge records for stream-gaging stations gives mean discharge for each day of the water year. In the monthly summary for the table, the line headed "TOTAL" gives the sum of the daily figures for each month; the line headed "MEAN" gives the average flow in cubic feet per second for the month; and the lines headed "MAX" and "MIN" give the maximum and minimum daily mean discharges, respectively, for each month. Discharge for the month also is usually expressed in cubic feet per second per square mile (line headed "CFSM"); or in inches (line headed "IN.") or in acre-feet (line headed "AC-FT"). Figures for cubic feet per second per square mile and runoff in inches or in acre-feet may be omitted if there is extensive regulation or diversion or if the drainage area includes large noncontributing areas.

\section{Statistics of Monthly Mean Data}

A tabular summary of the mean (line headed "MEAN"), maximum (line headed MAX), and minimum (line headed "MIN") of monthly mean flows for each month for a designated period is provided below the daily mean values table. The water years of the first occurrence of the maximum and minimum monthly flows are provided immediately below those figures. The designated period will be expressed as "FOR WATER YEARS BY WATER YEAR (WY)," and will list the first and last water years of the range of years selected from the PERIOD OF RECORD paragraph in the station manuscript. It will consist of all of the station record within the specified water years, inclusive, including complete months of record for partial water years, if any, and may coincide with the period of record for the station. The water years for which the statistics are computed will be consecutive, unless a break in the station record is indicated in the manuscript.

\section{Summary Statistics}

A table titled "SUMMARY STATISTICS" follows the statistics of monthly mean data. This table consists of five columns with the first column containing the line headings of the statistics being reported. The table provides a statistical summary of yearly, daily, and instantaneous flows, not only for the current water year but also for the previous calendar year and for a designated period, as appropriate. The designated period selected, "WATER YEARS ______," will consist of all the station record within the specified water years, inclusive, including complete months of record for partial water year, if any, and may coincide with the period of record for the station. The water years for which the statistics 
are computed will be consecutive, unless a break in the station record is indicated in the manuscript. All of the calculations for the statistical characteristics designated ANNUAL (See line headings below.), except for the "ANNUAL SEVEN-DAY MINIMUM" statistic, are calculated for the designated period using complete water years. The other statistical characteristics may be calculated using partial water years.

The date or water year, as appropriate, of the first occurrence of each statistic reporting extreme values of discharge is provided adjacent to the statistic. Repeated occurrences may be noted in the REMARKS paragraph of the manuscript or in footnotes. Because the designated period may not be the same as the station period of record published in the manuscript, occasionally the dates of occurrence listed for the daily and instantaneous extremes in the designated-period column may not be within the selected water years listed in the heading. When this occurs, it will be noted in the REMARKS paragraph or in footnotes. Selected streamflow duration curve statistics and runoff data also are given. Runoff data may be omitted if there is extensive regulation or diversion of flow in the drainage basin.

The following summary statistics data, as appropriate, are provided with each continuous record of discharge. Comments to follow clarify information presented under the various line headings of the summary statistics table.

ANNUAL TOTAL.--The sum of the daily mean values of discharge for the year.

ANNUAL MEAN.--The arithmetic mean of the individual daily mean discharges for the year noted or for the designated period.

HIGHEST ANNUAL MEAN.--The maximum annual mean discharge occurring for the designated period.

LOWEST ANNUAL MEAN.--The minimum annual mean discharge occurring for the designated period.

HIGHEST DAILY MEAN.--The maximum daily mean discharge for the year or for the designated period.

LOWEST DAILY MEAN.--The minimum daily mean discharge for the year or for the designated period.

ANNUAL SEVEN-DAY MINIMUM.--The lowest mean discharge for seven consecutive days for a calendar year or a water year. Note that most low-flow frequency analysis of annual seven-day minimum flows use a climatic year (April 1-March 31). The date shown in the summary statistics table is the initial date of the seven-day period. (This value should not be confused with the seven-day 10-year low-flow statistic.)

INSTANTANEOUS PEAK FLOW.--The maximum instantaneous discharge occurring for the water year or for the designated period. Note that secondary instantaneous peak discharges above a selected base discharge are stored in District computer files for stations meeting certain criteria. Those discharge values may be obtained by writing to the District Office.
INSTANTANEOUS PEAK STAGE.--The maximum instantaneous stage occurring for the water year or for the designated period. If the dates of occurrence for the instantaneous peak flow and instantaneous peak stage differ, the REMARKS paragraph in the manuscript or a footnote may be used to provide further information.

ANNUAL RUNOFF.--Indicates the total quantity of water in runoff for a drainage area for the year. Data reports may use any of the following units of measurement in presenting annual runoff data:

Acre-foot (AC-FT) is the quantity of water required to cover 1 acre to a depth of 1 foot and is equal to 43,560 cubic feet or about 326,000 gallons or 1,233 cubic meters.

Cubic feet per second per square mile (CFSM) is the number of cubic feet of water flowing per second from each square mile area drained, assuming the runoff is distributed uniformly in time and area.

Inches (INCHES) indicates the depth to which the drainage area would be covered if all the runoff for a given time period were uniformly distributed on it.

10 PERCENT EXCEEDS.--The discharge is exceeded 10 percent of the time for the designated period.

50 PERCENT EXCEEDS.--The discharge is exceeded 50 percent of the time for the designated period.

90 PERCENT EXCEEDS.--The discharge is exceeded 90 percent of the time for the designated period.

\section{Hydrograph}

A hydrograph for the current year follows the table for most stations. Streamflow hydrographs are semilog plot of mean daily values with no flow days showing as blanks. Those measurements and others collected for some special reason are called miscellaneous sites.

\section{Identifying Estimated Discharge}

Estimated daily-discharge values published in the water-discharge tables are identified by flagging individual daily values with the letter symbol " $e$ " and printing a table footnote, "e Estimated."

\section{Accuracy of the Records}

The accuracy of streamflow records depends primarily on: (1) The stability of the stage-discharge relation or, if the control is unstable, the frequency of discharge measurements; and (2) the accuracy of 
measurements of stage, measurements of discharge, and interpretation of records.

The accuracy attributed to the records is indicated under "REMARKS." "Excellent" means that about 95 percent of the daily discharges are within 5 percent of the true; "good," within 10 percent; and "fair," within 15 percent. Records that do not meet the criteria mentioned, are rated "poor." Different accuracies may be attributed to different parts of a given record.

Daily mean discharges in this report are given to the nearest hundredth of a cubic foot per second for values less than 1 cubic feet per second; to the nearest tenth between 1.0 and 10 cubic feet per second; to whole numbers between 10 and 1,000 cubic feet per second; and to 3 significant figures for more than 1,000 cubic feet per second. The number of significant figures used is based solely on the magnitude of the discharge value. The same rounding rules apply to discharges listed for partial-record stations and miscellaneous sites.

Discharge at many stations, as indicated by the monthly mean, may not reflect natural runoff due to the effects of diversion, consumption, regulation by storage, increase or decrease in evaporation due to artificial causes, or to other factors. For such stations, figures of cubic feet per second per square mile and of runoff, in inches, are not published unless satisfactory adjustments can be made for diversions, for changes in contents of reservoirs, or for other changes incident to use and control. Even at those stations where adjustments are made, large errors in computed runoff may occur if adjustments or losses are large in comparison with the observed discharge.

\section{Records of Surface-Water Quality}

Records of surface-water quality ordinarily are obtained at or near stream-gaging stations because interpretation of records of surface-water quality nearly always requires corresponding discharge data. Records of surface-water quality in this report may involve a variety of types of data and measurement frequencies.

\section{Classification of Records}

Water-quality data for surface-water sites are grouped into one of three classifications. A continuing-record station is a site where data are collected on a regularly scheduled basis. Frequency may be one or more times daily, weekly, monthly, or quarterly. A partial-record station is a site where limited water-quality data are collected systematically over a period of years. Frequency of sampling is usually less than quarterly. A miscellaneous sampling site is a location other than a continuing or partial-record station where random samples are collected to give better areal coverage to define water-quality conditions in the river basin.

\section{Arrangement of Records}

Water-quality records collected at a surface-water daily record station are published immediately following that record, regardless of the frequency of sample collection. Station number and name are the same for both records. Where a surface-water daily record station is not available or where the water quality differs significantly from that at the nearby surface-water station, the continuing water-quality record is published with its own station number and name in the regular downstream-order sequence. Water-quality data for partial-record stations and for miscellaneous sampling sites appear in separate tables following the table of discharge measurements at miscellaneous sites.

\section{On-site Measurements and Sample Collection}

In obtaining water-quality data, a major concern needs to be assuring that the data obtained represent the in situ quality of the water. To assure this, certain measurements, such as water temperature, $\mathrm{pH}$, and dissolved oxygen, need to be made onsite when the samples are taken. To assure that measurements made in the laboratory also represent the in situ water, carefully prescribed procedures need to be followed in collecting the samples, in treating the samples to prevent changes in quality pending analysis, and in shipping the samples to the laboratory. Procedures for on-site measurements and for collecting, treating, and shipping samples are detailed in technical publications and memoranda. These methods are consistent with ASTM standards and generally follow ISO standards.

One sample can define adequately the water quality at a given time if the mixture of solutes throughout the stream cross section is homogeneous. However, the concentration of solutes at different locations in the cross section may vary widely with different rates of water discharge, depending on the source of material and the turbulence and mixing of the stream. Some streams must be sampled through several vertical sections to obtain a representative sample needed for an accurate mean concentration and for use in calculating load. Whether samples are obtained from the centroid of flow or from several verticals, depends on flow conditions and other factors, which must be evaluated by the collector.

Chemical-quality data published in this report are considered to be the most representative values available for the stations listed. The values reported represent water-quality conditions at the time of sampling, as much as possible, consistent with available sampling techniques and methods of analysis. In the rare case where an apparent inconsistency exists between a reported $\mathrm{pH}$ value and the 
relative abundance of carbon dioxide species (carbonate and bicarbonate), the inconsistency is the result of a slight uptake of carbon dioxide from the air by the sample between measurement of $\mathrm{pH}$ in the field and determination of carbonate and bicarbonate in the laboratory.

\section{Water Temperature}

Water temperatures are measured at most of the water-quality stations. In addition, water temperatures are taken at time of discharge measurements for water-discharge stations. For stations where water temperatures are taken manually once or twice daily, the water temperatures are taken at about the same time each day. Large streams have a small diumal temperature change; shallow streams may have a daily range of several degrees and may follow closely the changes in air temperature. Some streams may be affected by waste-heat discharges.

\section{Laboratory Measurements}

Samples for ultimate carbonaceous biochemical-oxygen demand, 20 day, were analyzed locally. All other samples were analyzed in the Geological Survey laboratories in Ocala, Florida. Methods used by the U.S. Geological Survey laboratories are given in technical publications. These methods are consistent with ASTM standards and generally follow ISO standards.

\section{Data Presentation}

For continuing-record stations, information pertinent to the history of station operation is provided in descriptive headings preceding the tabular data. These descriptive headings give details regarding location, drainage area, period of record, type of data available, instrumentation, general remarks, cooperation, and extremes for parameters currently measured daily. Tables of chemical, physical, biological, radiochemical data, and so forth, obtained at a frequency less than daily are presented first. Tables of "daily values" of specific conductance, $\mathrm{pH}$, water temperature, and dissolved oxygen then follow in sequence.

LOCATION.--See Data Presentation under "Records of Stage and Water Discharge;" same comments apply.

DRAINAGE AREA.--See Data Presentation under "Records of Stage and Water Discharge;" same comments apply.

PERIOD OF RECORD.--This indicates the periods for which there are published water-quality records for the station. The periods are shown separately for records of parameters measured daily or continuously and those measured less than daily. For those measured daily or continuously, periods of record are given for the parameters individually.
INSTRUMENTATION.--Information on instrumentation is given only if a water-quality monitor, temperature recorder, sediment pumping sampler, or other sampling device is in operation at a station.

REMARKS.--Remarks provide added information pertinent to the collection, analysis, or computation of the records.

EXTREMES.--Maximums and minimums are given only for parameters measured daily or more frequently. None are given for parameters measured weekly or less frequently, because the true maximums or minimums may not have been sampled. Extremes, when given, are provided for both the period of record and for the current water year.

The surface-water-quality records for partial-record stations and miscellaneous sampling sites are published in separate tables following the table of discharge measurements at miscellaneous sites. No descriptive statements are given for these records. Each station is published with its own station number and name in the regular downstream-order sequence.

\section{Remarks Codes}

The following remark codes may appear with the water-quality data in this report:

\begin{tabular}{cl} 
PRINTED OUTPUT & \multicolumn{1}{c}{ REMARK } \\
E & Estimated value. \\
$>$ & Actual value is \\
known to be greater \\
than the value shown.
\end{tabular}

Water Quality-Control Data

Data generated from the quality-control (QC) samples are a requisite for evaluating the quality of the sampling and processing techniques as well as data from the actual samples themselves. Without QC data, environmental sample data cannot be adequately interpreted because the errors associated with the sample data are unknown. The various types of QC samples collected by this district are described in the following section. Procedures have been established for the storage of water-quality-control data within the USGS. These procedures allow for storage of all derived QC data and are identified so that they can be related to corresponding environmental samples.

Replicate Samples--Replicate samples are a set of environmental samples collected in a manner such that the samples are thought to be essentially identical in composition. Replicate is the general case for which a duplicate is the special case consisting of two samples. 
Replicate samples are collected and analyzed to establish the amount of variability in the data contributed by some part of the collection and analytical process. There are many types of replicate samples possible, each of which may yield slightly different results in a dynamic hydrollogic setting, such as a flowing stream. The types of replicate samples collected in this district are:

\section{Nutriont Calculations}

The values for many nitrogen parameters are calculated from other parameters. In some of these calculations, dissolved values are considered equivalent to total values.

\section{ACCESS TO USGS WATER DATA}

The USGS provides near real-time stage and discharge data for many of the gaging stations equipped with the necessary telemetry and historic daily-mean and peak-flow discharge data for most current or discontinued gaging stations through the world wide web (WWW). These data may be accessed at:

\section{http://www.water.usgs.gov}

Some water-quality and ground-water data also are available through the WWW. In addition, data can be provided in various machine-readable formats on magnetic tape or 3-1/2 inch floppy disk.

\section{DEFINITIONS OF TERMS}

Terms related to streamflow, water-quality, and other hydrologic data, as used in this report, are defined below. See also table for converting English units to Intemational System (SI) Units in the Contests pages.

Acre-foot (AC-FT, acre-ft) is the quantity of water required to cover 1 acre to a depth of 1 foot and is equal to 43,560 cubic feet or about 326,000 gallons or 1,233 cubic meters.

Algae are mostly aquatic single-cell, colonial, or multicelled plants, containing chlorophyll and lacking roots, stems, and leaves.

Biochemical oxygen demand (BOD) is a measure of the quantity of dissolved oxygen, in milligrams per liter, necessary for the decomposition of organic matter by microorganisms, such as bacteria.

Biomass is the amount of living matter present at any given time, expressed as the mass per unit area of volume of habitat.

Ash mass is the mass or amount of residue present after the residue from the dry mass determination has been ashed in a muffle furnace at a temperature of $500^{\circ} \mathrm{C}$ for 1 hour. The ash mass values of zooplankton and phytoplankton are expressed in grams per cubic meter $(\mathrm{g} / \mathrm{m} 3)$, and periphyton and benthic organisms in grams per square meter $(\mathrm{g} / \mathrm{m} 2)$.

Dry mass refers to the mass of residue present after drying in an oven at $105^{\circ} \mathrm{C}$ for zooplankton and periphyton, until the mass remains unchanged. This mass represents the total organic matter, ash and sediment, in the sample. Dry-mass values are expressed in the same units as ash mass.

Oroanic mass or volatile mass of the living substance is the difference between the dry mass and the ash mass and represents the actual mass of the living matter. The organic mass is expressed in the same units as for ash and dry mass.

Wetmass is the mass of living matter plus contained water.

Chlorophyll refers to the green pigments of plants. Chlorophyll $\mathrm{a}$ and $\mathrm{b}$ are the two most common green pigments in plants.

Code Numbers have been assigned for agencies collecting and analyzing samples, and are listed in water-quality tables of this report as follows:

1028 Oklahoma District, Water Resources Division (WRD), U.S. Geological Survey

81213 Quality of Water Services Unit, Ocala, Fla., WRD, U.S. Geological Survey

Control designates a feature downstream from the gage that determines the stage-discharge relation at the gage. This feature may be a natural constriction of the channel, an artificial structure, or a uniform cross section over a long reach of the channel.

Cubic foot per second $\left(\mathrm{ft}^{3} / \mathrm{s}\right)$ is the rate of discharge representing a volume of 1 cubic foot passing a given point during 1 second and is equivalent to 7.48 gallons per second or 448.8 gallons per minute or 0.02832 cubic meters per second.

Discharge is the volume of water (or more broadly, volume of fluid plus suspended sediment) that passes a given point within a given period of time.

Instantaneous discharge is the discharge at a particular instant of time.

Mean discharge (MEAN) is the arithmetic mean of individual daily mean discharges during a specific period.

Dissolved refers to that material in a representative water sample that passes through a 0.45 micrometer membrane filter. This is a convenient operational definition used by Federal agencies that collect water data. Determinations of "dissolved" constituents are made on subsamples of the filtrate.

Dissolved-solids concentration of water is determined either analytically by the "residue-on-evaporation" method, or mathematically by totaling the concentrations of individual constituents reported in a comprehensive chemical analysis. During the analytical determination of dissolved solids, the bicarbonate (generally a major dissolved component of 
water) is converted to carbonate. Therefore, in the mathematical calculation of dissolved-solids concentration, the bicarbonate value, in milligrams per liter, is multiplied by 0.492 to reflect the change.

Drainage area of a stream at a specified location is that area, measured in a horizontal plane, enclosed by a topographic divide from which direct surface runoff from precipitation normally drains by gravity into the stream above the specified point. Figures of drainage area given herein include all closed basins, or noncontributing areas, within the area unless otherwise noted.

Drainage basin is a part of the surface of the earth that is occupied by a drainage system, which consists of a surface stream or a body of impounded surface water together with all tributary surface streams and bodies of impounded surface water.

Gage height (G.H.) is the water-surface elevation referred to some arbitrary gage datum. Gage height is often used interchangeably with the more general term "stage," although gage height is more appropriate when used with a reading on a gage.

Gaging station is a particular site on a stream, canal, lake, or reservoir where systematic observations of hydrologic data are obtained.

Hydrologic unit is a geographic area representing part of all of a surface drainage basin or distinct hydrologic feature as delineated by the Office of Water Data Coordination on the State Hydrologic Unit Maps; each hydrologic unit is identified by an eight-digit number.

Micrograms per liter ( $\mathrm{UG} / \mathrm{L}, \mu \mathrm{g} / \mathrm{L}$ ) is a unit expressing the concentration of chemical constituents in solution as mass (micrograms) of solute per unit volume (liter) of water. One thousand micrograms per liter is equivalent to one milligram per liter.

Milligrams per liter (MG/L, $\mathrm{mg} / \mathrm{L}$ ) is a unit for expressing the concentration of chemical constituents in solution. Milligrams per liter represents the mass of solute per unit volume (liter) of water. Concentrations of suspended sediment also is expressed in $\mathrm{mg} / \mathrm{L}$ and is based on the mass of dry sediment per liter of water-sediment mixture.

Organism is any living entity.

Organism count/area refers to the number of organisms collected and enumerated in a sample and adjusted to the number per unit area habitat, usually square meter $\left(\mathrm{m}^{2}\right)$, acre, or hectare. Periphyton, benthic organisms, and macrophytes are expressed in these terms.

Organism count/volume refers to the number of organisms collected and enumerated in a sample and adjusted to the number per sample volume, usually milliliter (mL) or liter (L). Numbers of planktonic organisms can be expressed in these terms.

Total organism count is the total number of organisms collected and enumerated in any particular sample.
Parameter Code is a 5-digit number used in the U.S. Geological Survey data system, National Water Information System (NWIS), to uniquely identify a specific constituent. The codes used in NWIS are the same as those used in the U.S. Environmental Protection Agency data system, STORET.

Partial-record station is a particular site where limited streamflow and/or water-quality data are collected systematically over a period of years for use in hydrologic analyses.

Periphyton is the assemblage of microorganisms attached to and living upon submerged solid surfaces. While primarily consisting of algae, they also include bacteria, fungi, protozoa, rotifers, and other small organisms.

Plankton is the community of suspended, floating, or weakly swimming organisms that live in the open water of lakes and rivers.

Bhytoplankton is the plant part of the plankton. They are usually microscopic and their movement is subject to the water currents. Phytoplankton growth is dependent upon solar radiation and nutrient substances. Because they are able to incorporate as well as release materials to the surrounding water, the phytoplankton have a profound effect upon the quality of the water. They are the primary food producers in the aquatic environment, and are commonly know as algae.

Blue-green algae are a group of phytoplankton organisms having a blue pigment, in addition to the green pigment called chlorophyll. Blue-green algae often cause nuisance conditions in water.

Diatoms are the unicellular or colonial algae having a siliceous shell. Their concentrations are expressed as number of cells per milliliter (cells $/ \mathrm{mL}$ ) of sample.

Green algae have chlorophyll pigments similar in color to those of higher green plants. Some forms produce algae mats or floating "moss" in lakes. Their concentrations are expressed as number of cells per milliliter (cells/mL) of sample.

Zooplankton is the animal part of the plankton. Zooplankton are capable of extensive movements within the water column and are often large enough to be seen with the unaided eye. Zooplankton are secondary consumers feeding upon bacteria, phytoplankton, and detritus. Because they are the grazers in the aquatic environment, the zooplankton are a vital part of the aquatic food web. The zooplankton community is dominated by small crustaceans and rotifers.

Sea level is a geodetic datum derived from a general adjustment of the first order level nets of both the United States and Canada. It was formerly called "National Geodetic Vertical Datum of 1929 (NGVD of 1929)," 
"Sea Level Datum of 1929" or "mean sea level" in this series of reports. Although the datum was derived from the average sea level over a period of many years at 26 tide stations along the Atlantic, Gulf or Mexico, and Pacific Coasts, it does not necessarily represent local mean sea level at any particular place.

Solute is any substance that is dissolved in water.

Specific conductance is a measure of the ability of a water to conduct an electrical current. It is expressed in microsiemens per centimeter at $25^{\circ} \mathrm{C}$. Specific conductance is related to the type and concentration of ions in solution and can be used for approximating the dissolved-solids content of the water. Commonly, the concentration of dissolved solids (in milligrams per liter) is about 65 percent of the specific conductance (in microsiemens). This relation is not constant from stream to stream, and it may vary in the same source with changes in the composition of the water.

Stage-discharge relation is the relation between gage height (stage) and the volume of water, per unit of time, flowing in a channel.

Streamflow is the discharge that occurs in a natural channel. Although the term "discharge" can be applied to the flow of a canal, the word "streamflow" uniquely describes the discharge in a surface stream course. The term "streamflow" is more general than "runoff" as streamflow may be applied to discharge whether or not it is affected by diversion or regulation.

Substrate is the physical surface upon which an organism lives.

Natural substrate refers to any naturally occurring or submersed solid surface, such as a rock or tree, upon which an organism lives.

Artificial substrate is a device that is purposely placed in a stream or lake for colonization of organisms. The artificial substrate simplifies the community structure by standardizing the substrate from which each sample is taken. Examples of artificial substrates are basket samplers (made of wire cages filled with clean streamside rocks) and multiplet samplers (made of hardboard) for benthic organism collection, and plexiglass strips for periphyton.

Suspended (as used in tables of chemical analyses) refers to the amount (concentration) of undissolved material in a water-sediment mixture. It is associated with the material retained on a 0.45 -micrometer filter.

Suspended. recoverable is the amount of a given constituent that is in solution after the part of a representative water-suspended sediment sample that is retained on a 0.45 micrometer membrane filter has been digested by a method (usually using a dilute acid solution) that results in dissolution of only readily soluble substances. Complete dissolution of all the particulate matter is not achieved by the digestion treatment and thus the determination represents something less than the "total" amount (that is, less than 95 percent) of the constituent present in the sample. To achieve comparability of analytical data, equivalent digestion procedures are required of all laboratories performing such analyses because different digestion procedures are likely to produce different analytical results.

Determinations of "suspended, recoverable" constituents are made either by analyzing portions of the material collected on the filter or, more commonly, by difference, based on determinations of (1) dissolved and (2) total recoverable concentrations of the constituent.

Suspended.total is the total amount of a given constituent in the part of a representative water-suspended sediment sample that is retained on a $0.45 \mu \mathrm{m}$ membrane filter. This term is used only when the analytical procedure assures measurement of at least 95 percent of the constituent determined. A knowledge of the expected form of the constituent in the sample, as well as the analytical methodology used, is required to determine when the results should be reported as "suspended, total."

Determinations of "suspended, total" constituents are made either by analyzing portions of the material collected on the filter or, more commonly, by difference, based on determinations of (1) dissolved and (2) total concentrations of the constituent.

Total is the total amount of a given constituent in a representative water-suspended sediment sample, regardless of the physical or chemical form. This term is used only when the analytical procedure assures measurement of at least 95 percent of the constituent present in both the dissolved and suspended phases of the sample. A knowledge of the expected form of the constituent in the sample, as well as the analytical methodology used, is required to judge when the results should be reported as "total." (Note that the word "total" does double duty here, indicating both that the sample consists of a water-suspended sediment mixture and that the analytical method determines all of the constituent in the sample.)

Total recoverable is the amount of a given constituent that is in solution after a representative water-suspended sediment sample has been digested by a method (usually using a dilute acid solution) that results in dissolution of only readily soluble substances. Complete dissolution of all particulate matter is not achieved by the digestion treatment, and thus the determination represents something less than the "total" amount (that is, less than 95 percent) of the constituent present in the dissolved and suspended phases of the sample. To achieve comparability of analytical data, equivalent digestion procedures are required of all laboratories performing such analyses, because different digestion procedures are likely to produce different analytical results.

Water year in Geological Survey reports dealing with surface-water supply is the 12-month period, Oct. 1 through 
Sept. 30. The water year is designated by the calendar year in which it ends and which includes 9 of the 12 months. Thus, the year ending Sept. 30, 1995, is called the "1995 water year."
WSP is used as an abbreviation for "Water-Supply Paper" in references to previously published reports. 
LOCATION.--Lat $34^{\circ} 14^{\prime} 33^{\prime \prime}$, long $97^{\circ} 06^{\prime} 28^{\prime \prime}$, in NW 1/4 NW 1/4 sec.4, T.4 S., R.2 E., Carter County, Hydrologic Unit 11130303, on left bank on downstream side of bridge on Refinery Road, 3 mi north of Ardmore, 2 mi east of State Highway 77, and at mile 18.0. DRAINAGE AREA.--298 $\mathrm{mi}^{2}$.

\section{WATER-DISCHARGE RECORDS}

PERIOD OF RECORD.--June 1936 to September 1950, March 1996 to current year. Prior to September 1950, monthly discharge only for some periods, published in WSP 1681.

GAGE.--Water-stage recorder. Datum of gage is $715 \mathrm{ft}$, by barometer. Prior to September 30, 1950, nonrecording gage at datum 709.43 ft above National Geodetic Vertical Datum of 1929 (levels by U.S. Army Corps of Engineers).

REMARKS.--Records fair. U.S. Geological Survey's satellite telemeter at station.

DISCHARGE, CUBIC FEET PER SECOND, WATER YEAR OCTOBER 1996 TO SEPTEMBER 1997

DAILY MEAN VALUES

\begin{tabular}{|c|c|c|c|c|c|c|c|c|c|c|c|c|}
\hline DAY & OCT & NOV & DEC & JAN & FEB & MAR & APR & MAY & JUN & JUL & AUG & SEP \\
\hline $\begin{array}{l}1 \\
2 \\
3 \\
4 \\
5\end{array}$ & $\begin{array}{l}99 \\
79 \\
65 \\
55 \\
49\end{array}$ & $\begin{array}{l}74 \\
66 \\
54 \\
50 \\
46\end{array}$ & $\begin{array}{l}627 \\
367 \\
247 \\
189 \\
162\end{array}$ & $\begin{array}{r}40 \\
41 \\
42 \\
42 \\
\text { e } 41\end{array}$ & $\begin{array}{l}29 \\
28 \\
27 \\
26 \\
25\end{array}$ & $\begin{array}{l}355 \\
270 \\
232 \\
199 \\
170\end{array}$ & $\begin{array}{r}47 \\
49 \\
51 \\
98 \\
301\end{array}$ & $\begin{array}{r}139 \\
114 \\
96 \\
81 \\
73\end{array}$ & $\begin{array}{l}569 \\
342 \\
187 \\
131 \\
103\end{array}$ & $\begin{array}{l}25 \\
22 \\
20 \\
19 \\
20\end{array}$ & $\begin{array}{l}8.1 \\
4.9 \\
3.9 \\
3.4 \\
3.0\end{array}$ & $\begin{array}{l}1.4 \\
1.1 \\
1.3 \\
4.4 \\
4.9\end{array}$ \\
\hline $\begin{array}{r}6 \\
7 \\
8 \\
9 \\
10\end{array}$ & $\begin{array}{l}45 \\
41 \\
42 \\
61 \\
48\end{array}$ & $\begin{array}{r}46 \\
476 \\
318 \\
156 \\
111\end{array}$ & $\begin{array}{l}282 \\
182 \\
135 \\
122 \\
102\end{array}$ & $\begin{array}{l}\text { e.37 } \\
\text { e.35 } \\
e 34 \\
e .37 \\
\text { e.38 }\end{array}$ & $\begin{array}{r}33 \\
140 \\
207 \\
127 \\
92\end{array}$ & $\begin{array}{l}144 \\
130 \\
125 \\
125 \\
142\end{array}$ & $\begin{array}{r}185 \\
113 \\
90 \\
79 \\
72\end{array}$ & $\begin{array}{r}68 \\
64 \\
71 \\
549 \\
363\end{array}$ & $\begin{array}{r}85 \\
74 \\
66 \\
148 \\
2110\end{array}$ & $\begin{array}{l}20 \\
19 \\
19 \\
15 \\
15\end{array}$ & $\begin{array}{l}3.8 \\
7.8 \\
6.5 \\
4.9 \\
4.3\end{array}$ & $\begin{array}{l}4.9 \\
3.4 \\
2.7 \\
2.7 \\
2.8\end{array}$ \\
\hline $\begin{array}{l}11 \\
12 \\
13 \\
14 \\
15\end{array}$ & $\begin{array}{l}29 \\
24 \\
22 \\
20 \\
19\end{array}$ & $\begin{array}{l}88 \\
74 \\
66 \\
61 \\
57\end{array}$ & $\begin{array}{l}87 \\
79 \\
75 \\
71 \\
78\end{array}$ & $\begin{array}{l}e 39 \\
e 30 \\
e 29 \\
e 31 \\
\text { e } 33\end{array}$ & $\begin{array}{l}77 \\
69 \\
64 \\
60 \\
55\end{array}$ & $\begin{array}{r}122 \\
110 \\
107 \\
100 \\
79\end{array}$ & $\begin{array}{r}1170 \\
1370 \\
485 \\
281 \\
196\end{array}$ & $\begin{array}{r}195 \\
121 \\
87 \\
74 \\
68\end{array}$ & $\begin{array}{l}719 \\
363 \\
277 \\
302 \\
183\end{array}$ & $\begin{array}{l}14 \\
12 \\
11 \\
11 \\
10\end{array}$ & $\begin{array}{l}3.7 \\
4.2 \\
5.7 \\
4.6 \\
4.0\end{array}$ & $\begin{array}{c}2.0 \\
1.0 \\
.95 \\
2.5 \\
1.0\end{array}$ \\
\hline $\begin{array}{l}16 \\
17 \\
18 \\
19 \\
20\end{array}$ & $\begin{array}{l}17 \\
19 \\
15 \\
13 \\
14\end{array}$ & $\begin{array}{r}63 \\
1590 \\
697 \\
366 \\
227\end{array}$ & $\begin{array}{l}70 \\
64 \\
59 \\
52 \\
52\end{array}$ & $\begin{array}{r}e 34 \\
e 28 \\
e 50 \\
51 \\
41\end{array}$ & $\begin{array}{r}51 \\
47 \\
46 \\
49 \\
3690\end{array}$ & $\begin{array}{l}72 \\
70 \\
72 \\
69 \\
65\end{array}$ & $\begin{array}{r}151 \\
129 \\
112 \\
99 \\
94\end{array}$ & $\begin{array}{r}60 \\
54 \\
50 \\
350 \\
527\end{array}$ & $\begin{array}{r}136 \\
123 \\
124 \\
72 \\
57\end{array}$ & $\begin{array}{r}12 \\
13 \\
13 \\
11 \\
9.6\end{array}$ & $\begin{array}{l}2.9 \\
2.7 \\
4.3 \\
7.5 \\
9.9\end{array}$ & $\begin{array}{r}1.1 \\
.89 \\
.79 \\
.71 \\
1.0\end{array}$ \\
\hline $\begin{array}{l}21 \\
22 \\
23 \\
24 \\
25\end{array}$ & $\begin{array}{l}277 \\
370 \\
279 \\
201 \\
162\end{array}$ & $\begin{array}{r}163 \\
123 \\
103 \\
1420 \\
1230\end{array}$ & $\begin{array}{l}56 \\
52 \\
51 \\
49 \\
43\end{array}$ & $\begin{array}{l}42 \\
41 \\
40 \\
39 \\
37\end{array}$ & $\begin{array}{r}4240 \\
1750 \\
1090 \\
737 \\
532\end{array}$ & $\begin{array}{l}63 \\
61 \\
58 \\
59 \\
67\end{array}$ & $\begin{array}{r}129 \\
117 \\
98 \\
86 \\
227\end{array}$ & $\begin{array}{l}306 \\
220 \\
160 \\
115 \\
102\end{array}$ & $\begin{array}{l}48 \\
42 \\
53 \\
56 \\
48\end{array}$ & $\begin{array}{l}8.8 \\
8.4 \\
8.1 \\
7.3 \\
7.1\end{array}$ & $\begin{array}{l}5.6 \\
6.7 \\
9.3 \\
7.9 \\
4.7\end{array}$ & $\begin{array}{l}2.0 \\
1.4 \\
3.2 \\
2.6 \\
5.4\end{array}$ \\
\hline $\begin{array}{l}26 \\
27 \\
28 \\
29 \\
30 \\
31\end{array}$ & $\begin{array}{r}118 \\
79 \\
72 \\
67 \\
59 \\
63\end{array}$ & $\begin{array}{r}880 \\
649 \\
394 \\
1250 \\
1310 \\
---\end{array}$ & $\begin{array}{l}41 \\
42 \\
42 \\
41 \\
40 \\
39\end{array}$ & $\begin{array}{l}36 \\
33 \\
30 \\
28 \\
30 \\
29\end{array}$ & $\begin{array}{r}1070 \\
1010 \\
516 \\
--- \\
-- \\
-\end{array}$ & $\begin{array}{l}84 \\
64 \\
60 \\
56 \\
54 \\
51\end{array}$ & $\begin{array}{r}1010 \\
715 \\
415 \\
258 \\
182 \\
---\end{array}$ & $\begin{array}{r}160 \\
160 \\
108 \\
88 \\
1650 \\
1760\end{array}$ & $\begin{array}{r}43 \\
38 \\
34 \\
32 \\
28 \\
--\end{array}$ & $\begin{array}{l}6.3 \\
5.0 \\
4.7 \\
5.2 \\
9.2 \\
9.3\end{array}$ & $\begin{array}{l}2.7 \\
2.5 \\
1.9 \\
1.8 \\
1.5 \\
1.6\end{array}$ & $\begin{array}{r}3.9 \\
3.0 \\
2.9 \\
2.5 \\
2.9 \\
--\end{array}$ \\
\hline $\begin{array}{l}\text { TOTAL } \\
\text { MEAN } \\
\text { MAX } \\
\text { MIN } \\
\text { AC-FT }\end{array}$ & $\begin{array}{r}2523 \\
81.4 \\
370 \\
13 \\
5000\end{array}$ & $\begin{array}{r}12208 \\
407 \\
1590 \\
46 \\
24210\end{array}$ & $\begin{array}{r}3598 \\
116 \\
627 \\
39 \\
7140\end{array}$ & $\begin{array}{r}1138 \\
36.7 \\
51 \\
28 \\
2260\end{array}$ & $\begin{array}{r}15887 \\
567 \\
4240 \\
25 \\
31510\end{array}$ & $\begin{array}{r}3435 \\
111 \\
355 \\
51 \\
6810\end{array}$ & $\begin{array}{r}8409 \\
280 \\
1370 \\
47 \\
16680\end{array}$ & $\begin{array}{r}8033 \\
259 \\
1760 \\
50 \\
15930\end{array}$ & $\begin{array}{r}6593 \\
220 \\
2110 \\
28 \\
13080\end{array}$ & $\begin{array}{r}390.0 \\
12.6 \\
25 \\
4.7 \\
774\end{array}$ & $\begin{array}{r}146.3 \\
4.72 \\
9.9 \\
1.5 \\
290\end{array}$ & $\begin{array}{r}71.34 \\
2.38 \\
5.4 \\
.71 \\
142\end{array}$ \\
\hline
\end{tabular}

e Estimated 
07330500 CADDO CREEK NEAR ARDMORE, OK--Continued

STATISTICS OF MONTHLY MEAN DATA FOR WATER YEARS 1937 - 1997, BY WATER YEAR (WY)

\begin{tabular}{|c|c|c|c|c|c|c|c|c|c|c|c|c|}
\hline & OCT & NOV & DEC & JAN & FEB & MAR & APR & MAY & JUN & JUL & AUG & SEP \\
\hline $\begin{array}{l}\text { MEAN } \\
\text { MAX }\end{array}$ & $\begin{array}{l}180 \\
1736\end{array}$ & 86.0 & $\begin{array}{l}86.4 \\
816\end{array}$ & $\begin{array}{l}70.8 \\
567\end{array}$ & $\begin{array}{l}219 \\
1065\end{array}$ & $\begin{array}{l}214 \\
1672\end{array}$ & $\begin{array}{l}293 \\
1349\end{array}$ & $\begin{array}{l}264 \\
919\end{array}$ & $\begin{array}{l}185 \\
512\end{array}$ & $\begin{array}{l}71.3 \\
583\end{array}$ & $\begin{array}{l}77.3 \\
289\end{array}$ & $\begin{array}{l}88.6 \\
778\end{array}$ \\
\hline (WY) & 1942 & 1997 & 1947 & 1946 & 1938 & 1945 & 1942 & 1943 & 1940 & 1945 & 1950 & 1945 \\
\hline $\begin{array}{l}\text { MIN } \\
\text { (WY) }\end{array}$ & $\begin{array}{l}.000 \\
1939\end{array}$ & $\begin{array}{l}.000 \\
1939\end{array}$ & $\begin{array}{l}.000 \\
1939\end{array}$ & $\begin{array}{l}.24 \\
1949\end{array}$ & $\begin{array}{l}1.89 \\
1939\end{array}$ & $\begin{array}{l}1.37 \\
1940\end{array}$ & $\begin{array}{l}13.8 \\
1948\end{array}$ & $\begin{array}{l}3.92 \\
1939\end{array}$ & $\begin{array}{l}8.83 \\
1937\end{array}$ & $\begin{array}{l}2.41 \\
1944\end{array}$ & $\begin{array}{l}.12 \\
1943\end{array}$ & $\begin{array}{r}.000 \\
1948\end{array}$ \\
\hline
\end{tabular}

\section{SUMMARY STATISTICS}

1997 WATER YEAR

WATER YEARS 1937 - 97

ANNUAL TOTAL

ANNUAL MEAN

HIGHEST ANNUAL MEAN

LOWEST ANNUAL MEAN

HIGHEST DAILY MEAN

LOWEST DAILY MEAN

ANNUAL SEVEN-DAY MINIMUM

INSTANTANEOUS PEAK FLOW

INSTANTANEOUS PEAK STAGE

62431.64

ANNUAL RUNOFF (AC-FT)

10 PERCENT EXCEEDS

50 PERCENT EXCEEDS

90 PERCENT EXCEEDS

\begin{tabular}{|c|c|c|c|}
\hline 171 & & $\begin{array}{r}155 \\
419 \\
9.38\end{array}$ & $\begin{array}{l}1945 \\
1939\end{array}$ \\
\hline 4240 & Feb 21 & 16700 & Mar 151945 \\
\hline .71 & Sep 19 & .00 & at times \\
\hline 1.1 & Sep 15 & .00 & Aug 11937 \\
\hline 6120 & Feb 20 & 22300 & $\operatorname{Mar} 151945$ \\
\hline 29.30 & Feb 20 & 29.30 & Feb 201997 \\
\hline 123800 & & 112200 & \\
\hline 364 & & 243 & \\
\hline 56 & & 18 & \\
\hline 3.8 & & .00 & \\
\hline
\end{tabular}

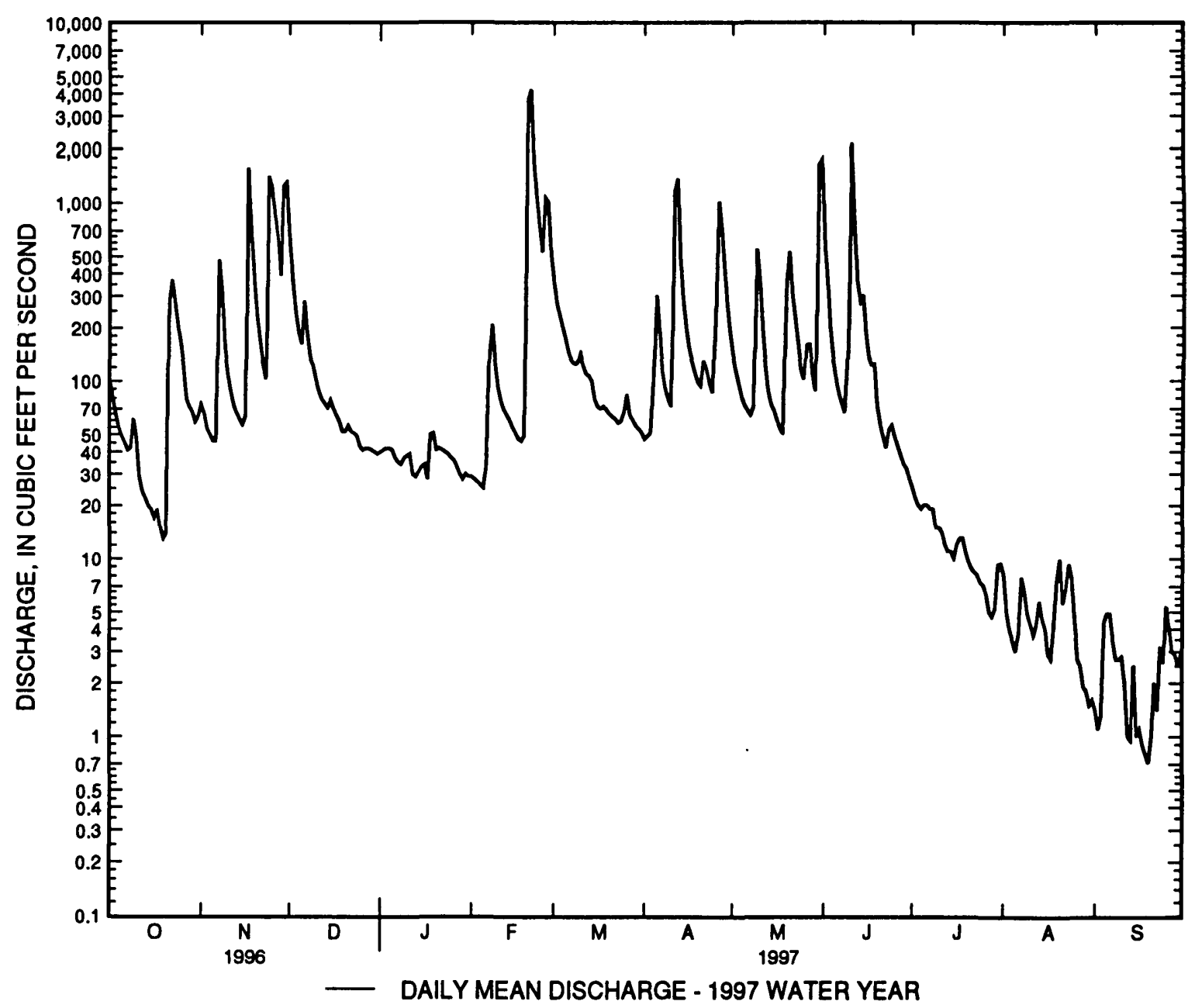


PERIOD OF RECORD.--April 1996 to current year.

PERIOD OF DAILY RECORD.--

SPECIFIC CONDUCTANCE: April 1996 to current year.

pH: April 1996 to current year.

WATER TEMPERATURE: April 1996 to current year.

DISSOLVED OXYGEN: April 1996 to current year.

INSTRUMENTATION.--Water-quality monitor since April 1996.

REMARKS.--Interruptions in record were due to malfunction of the recording instruments.

EXTREMES FOR PERIOD OF DAILY RECORD.--

SPECIFIC CONDUCTANCE: Maximum, 1330 microsiemens, June 18, 1997; minimum, 170 microsiemens, Sept. $15,1996$.

pH: Maximum, 9.0 units, Sept. 20, 22, 1997; minimum, 7.4 units, Feb. 20, 1997.

WATER TEMPERATURE: Maximum, $38.0^{\circ} \mathrm{C}$, July 7,1996 ; minimum, $0.0^{\circ} \mathrm{C}$, many days during winter period.

DISSOLVED OXYGEN: Maximum, 13.9 mg/L, Dec. 19, 1996, June 17, 18, 1997; minimum, 2.4 mg/L, July 8, 1996.

EXTREMES FOR CURRENT YEAR.--

SPECIFIC CONDUCTANCE: Maximum, 1330 microsiemens, June 18; minimum, 184 microsiemens, Feb. 20.

pH: Maximum, 9.0 units, Sept. 20, 22; minimum, 7.4 units, Feb. 20.

WATER TEMPERATURE: Maximum, $37.0^{\circ} \mathrm{C}$, July 27,28 ; minimum, $0.0^{\circ} \mathrm{C}$, many days during winter period.

DISSOLVED OXYGEN: Maximum, 13.9 mg/L, Dec. 19, June 17, 18; minimum, $5.2 \mathrm{mg} / \mathrm{L}$, Sept. 20.

SPECIFIC CONDUCTANCE, US/CM @ 25 DEGREES CELSIUS, WATER YEAR OCTOBER 1996 TO SEPTEMBER 1997

\begin{tabular}{|c|c|c|c|c|c|c|c|c|c|c|c|c|}
\hline \multirow[t]{2}{*}{ DAY } & MAX & MIN & MEAN & MAX & MIN & MEAN & MAX & MIN & MEAN & MAX & MIN & MEAN \\
\hline & \multicolumn{3}{|c|}{ OCTOBER } & \multicolumn{3}{|c|}{ NOVEMBER } & \multicolumn{3}{|c|}{ DECEMBER } & \multicolumn{3}{|c|}{ JANUARY } \\
\hline $\begin{array}{l}1 \\
2 \\
3 \\
4 \\
5\end{array}$ & $\begin{array}{l}391 \\
400 \\
405 \\
414 \\
420\end{array}$ & $\begin{array}{l}384 \\
390 \\
399 \\
405 \\
414\end{array}$ & $\begin{array}{l}387 \\
394 \\
402 \\
410 \\
417\end{array}$ & $\begin{array}{l}450 \\
632 \\
640 \\
554 \\
513\end{array}$ & $\begin{array}{l}419 \\
450 \\
554 \\
500 \\
485\end{array}$ & $\begin{array}{l}439 \\
530 \\
600 \\
523 \\
493\end{array}$ & $\begin{array}{l}370 \\
405 \\
440 \\
464 \\
483\end{array}$ & $\begin{array}{l}336 \\
370 \\
405 \\
440 \\
463\end{array}$ & $\begin{array}{l}351 \\
388 \\
421 \\
452 \\
473\end{array}$ & $\begin{array}{l}824 \\
810 \\
741 \\
746 \\
749\end{array}$ & $\begin{array}{l}781 \\
709 \\
708 \\
713 \\
714\end{array}$ & $\begin{array}{l}801 \\
770 \\
727 \\
731 \\
729\end{array}$ \\
\hline $\begin{array}{r}6 \\
7 \\
8 \\
9 \\
10\end{array}$ & $\begin{array}{l}428 \\
433 \\
446 \\
478 \\
415\end{array}$ & $\begin{array}{l}420 \\
425 \\
429 \\
408 \\
407\end{array}$ & $\begin{array}{l}424 \\
430 \\
434 \\
439 \\
411\end{array}$ & $\begin{array}{l}485 \\
621 \\
655 \\
412 \\
424\end{array}$ & $\begin{array}{l}441 \\
233 \\
405 \\
405 \\
412\end{array}$ & $\begin{array}{l}474 \\
316 \\
454 \\
408 \\
418\end{array}$ & $\begin{array}{l}578 \\
487 \\
498 \\
--- \\
---\end{array}$ & $\begin{array}{l}417 \\
411 \\
487 \\
--- \\
---\end{array}$ & $\begin{array}{l}466 \\
449 \\
495 \\
--- \\
---\end{array}$ & $\begin{array}{l}760 \\
771 \\
771 \\
748 \\
762\end{array}$ & $\begin{array}{l}722 \\
746 \\
729 \\
723 \\
738\end{array}$ & $\begin{array}{l}743 \\
759 \\
758 \\
739 \\
746\end{array}$ \\
\hline $\begin{array}{l}11 \\
12 \\
13 \\
14 \\
15\end{array}$ & $\begin{array}{l}450 \\
488 \\
509 \\
519 \\
528\end{array}$ & $\begin{array}{l}415 \\
450 \\
488 \\
503 \\
512\end{array}$ & $\begin{array}{l}426 \\
471 \\
502 \\
514 \\
521\end{array}$ & $\begin{array}{l}435 \\
444 \\
454 \\
463 \\
477\end{array}$ & $\begin{array}{l}424 \\
435 \\
444 \\
454 \\
463\end{array}$ & $\begin{array}{l}428 \\
438 \\
448 \\
459 \\
469\end{array}$ & $\begin{array}{l}--- \\
--- \\
--- \\
--- \\
---\end{array}$ & $\begin{array}{l}--- \\
--- \\
--- \\
--- \\
---\end{array}$ & $\begin{array}{l}--- \\
--- \\
--- \\
--- \\
---\end{array}$ & $\begin{array}{l}834 \\
857 \\
820 \\
916 \\
872\end{array}$ & $\begin{array}{l}762 \\
702 \\
674 \\
813 \\
802\end{array}$ & $\begin{array}{l}795 \\
798 \\
737 \\
868 \\
838\end{array}$ \\
\hline $\begin{array}{l}16 \\
17 \\
18 \\
19 \\
20\end{array}$ & $\begin{array}{l}531 \\
532 \\
537 \\
561 \\
566\end{array}$ & $\begin{array}{l}515 \\
505 \\
513 \\
530 \\
512\end{array}$ & $\begin{array}{l}527 \\
521 \\
530 \\
547 \\
559\end{array}$ & $\begin{array}{l}486 \\
424 \\
348 \\
362 \\
399\end{array}$ & $\begin{array}{l}424 \\
239 \\
334 \\
336 \\
362\end{array}$ & $\begin{array}{l}479 \\
303 \\
344 \\
348 \\
381\end{array}$ & $\begin{array}{l}--- \\
615 \\
645 \\
666 \\
692\end{array}$ & $\begin{array}{l}--- \\
593 \\
615 \\
529 \\
529\end{array}$ & $\begin{array}{l}--- \\
603 \\
633 \\
642 \\
651\end{array}$ & $\begin{array}{l}831 \\
826 \\
956 \\
692 \\
745\end{array}$ & $\begin{array}{l}755 \\
635 \\
573 \\
475 \\
671\end{array}$ & $\begin{array}{l}796 \\
726 \\
723 \\
583 \\
704\end{array}$ \\
\hline $\begin{array}{l}21 \\
22 \\
23 \\
24 \\
25\end{array}$ & $\begin{array}{l}603 \\
605 \\
414 \\
403 \\
373\end{array}$ & $\begin{array}{l}291 \\
389 \\
399 \\
373 \\
367\end{array}$ & $\begin{array}{l}440 \\
440 \\
406 \\
383 \\
370\end{array}$ & $\begin{array}{l}428 \\
451 \\
463 \\
456 \\
291\end{array}$ & $\begin{array}{l}399 \\
428 \\
451 \\
204 \\
282\end{array}$ & $\begin{array}{l}413 \\
439 \\
456 \\
293 \\
285\end{array}$ & $\begin{array}{l}732 \\
--- \\
--- \\
--- \\
---\end{array}$ & $\begin{array}{l}673 \\
--- \\
--- \\
--- \\
---\end{array}$ & $\begin{array}{l}699 \\
--- \\
--- \\
--- \\
---\end{array}$ & \begin{tabular}{l}
734 \\
715 \\
-- \\
\hdashline 767
\end{tabular} & $\begin{array}{l}694 \\
685 \\
--- \\
--- \\
725\end{array}$ & $\begin{array}{l}710 \\
702 \\
--- \\
--- \\
747\end{array}$ \\
\hline $\begin{array}{l}26 \\
27 \\
28 \\
29 \\
30 \\
31\end{array}$ & $\begin{array}{l}373 \\
391 \\
402 \\
--- \\
-- \\
450\end{array}$ & $\begin{array}{l}366 \\
373 \\
390 \\
--- \\
-- \\
416\end{array}$ & $\begin{array}{l}368 \\
385 \\
395 \\
-- \\
-- \\
439\end{array}$ & $\begin{array}{l}351 \\
345 \\
381 \\
392 \\
336 \\
---\end{array}$ & $\begin{array}{l}288 \\
331 \\
345 \\
263 \\
292 \\
-\end{array}$ & $\begin{array}{l}315 \\
338 \\
363 \\
329 \\
317 \\
-\end{array}$ & $\begin{array}{l}--- \\
--- \\
--- \\
--- \\
--- \\
899\end{array}$ & $\begin{array}{l}--- \\
--- \\
--- \\
--- \\
--- \\
810\end{array}$ & $\begin{array}{l}--- \\
-\cdots \\
--- \\
--- \\
--- \\
853\end{array}$ & $\begin{array}{l}776 \\
767 \\
765 \\
798 \\
814 \\
816\end{array}$ & $\begin{array}{l}728 \\
738 \\
748 \\
750 \\
754 \\
711\end{array}$ & $\begin{array}{l}754 \\
755 \\
756 \\
772 \\
779 \\
776\end{array}$ \\
\hline NTH & -- & -- & -- & 655 & 204 & 410 & --- & -- & --- & $\ldots$ & $\ldots$ & -- \\
\hline
\end{tabular}


07330500 CADDO CREEK NEAR ARDMORE, OK-Continued

SPECIFIC CONDUCTANCE, US/CM @ 25 DEGREES CELSIUS, WATER YEAR OCTOBER 1996 TO SEPTEMBER 1997

\begin{tabular}{|c|c|c|c|c|c|c|c|c|c|c|c|c|}
\hline \multirow[t]{2}{*}{ DAY } & MAX & MIN & MEAN & MAX & MIN & MEAN & MAX & MIN & MEAN & MAX & MIN & MEAN \\
\hline & \multicolumn{3}{|c|}{ FEBRUARY } & \multicolumn{3}{|c|}{ MARCH } & \multicolumn{3}{|c|}{ APRIL } & \multicolumn{3}{|c|}{ MAY } \\
\hline $\begin{array}{l}1 \\
2 \\
3 \\
4 \\
5\end{array}$ & $\begin{array}{l}810 \\
843 \\
849 \\
851 \\
873\end{array}$ & $\begin{array}{l}779 \\
781 \\
795 \\
809 \\
835\end{array}$ & $\begin{array}{l}793 \\
808 \\
827 \\
835 \\
857\end{array}$ & $\begin{array}{l}509 \\
541 \\
580 \\
607 \\
628\end{array}$ & $\begin{array}{l}443 \\
509 \\
541 \\
580 \\
607\end{array}$ & $\begin{array}{l}477 \\
525 \\
561 \\
594 \\
616\end{array}$ & $\begin{array}{r}1070 \\
1060 \\
998 \\
859 \\
1320\end{array}$ & $\begin{array}{l}889 \\
883 \\
859 \\
732 \\
712\end{array}$ & $\begin{array}{l}921 \\
948 \\
906 \\
784 \\
934\end{array}$ & $\begin{array}{l}792 \\
--- \\
--- \\
-- \\
---\end{array}$ & $\begin{array}{l}627 \\
--- \\
-- \\
--- \\
---\end{array}$ & $\begin{array}{l}669 \\
--- \\
--- \\
--- \\
---\end{array}$ \\
\hline $\begin{array}{r}6 \\
7 \\
8 \\
9 \\
10\end{array}$ & $\begin{array}{l}857 \\
811 \\
894 \\
693 \\
661\end{array}$ & $\begin{array}{l}797 \\
522 \\
528 \\
661 \\
634\end{array}$ & $\begin{array}{l}828 \\
664 \\
747 \\
674 \\
645\end{array}$ & $\begin{array}{l}647 \\
655 \\
678 \\
704 \\
903\end{array}$ & $\begin{array}{l}628 \\
645 \\
656 \\
678 \\
696\end{array}$ & $\begin{array}{l}638 \\
648 \\
668 \\
685 \\
781\end{array}$ & $\begin{array}{l}916 \\
686 \\
695 \\
786 \\
896\end{array}$ & $\begin{array}{l}688 \\
643 \\
650 \\
695 \\
786\end{array}$ & $\begin{array}{l}745 \\
659 \\
667 \\
736 \\
830\end{array}$ & $\begin{array}{l}--- \\
--- \\
--- \\
--- \\
---\end{array}$ & $\begin{array}{l}--- \\
--- \\
--- \\
---\end{array}$ & $\begin{array}{l}--- \\
-\cdots \\
-\cdots \\
--- \\
--\end{array}$ \\
\hline $\begin{array}{l}11 \\
12 \\
13 \\
14 \\
15\end{array}$ & $\begin{array}{l}643 \\
663 \\
678 \\
692 \\
704\end{array}$ & $\begin{array}{l}633 \\
643 \\
659 \\
669 \\
690\end{array}$ & $\begin{array}{l}638 \\
648 \\
664 \\
678 \\
697\end{array}$ & $\begin{array}{l}915 \\
698 \\
715 \\
827 \\
856\end{array}$ & $\begin{array}{l}686 \\
680 \\
692 \\
701 \\
815\end{array}$ & $\begin{array}{l}779 \\
687 \\
704 \\
767 \\
839\end{array}$ & $\begin{array}{l}911 \\
488 \\
529 \\
571 \\
734\end{array}$ & $\begin{array}{l}317 \\
403 \\
488 \\
529 \\
573\end{array}$ & $\begin{array}{l}595 \\
424 \\
502 \\
553 \\
623\end{array}$ & $\begin{array}{l}--- \\
--- \\
-- \\
---\end{array}$ & $\begin{array}{l}--- \\
--- \\
--- \\
---\end{array}$ & $\begin{array}{l}--- \\
--- \\
--- \\
--- \\
---\end{array}$ \\
\hline $\begin{array}{l}16 \\
17 \\
18 \\
19 \\
20\end{array}$ & $\begin{array}{l}711 \\
715 \\
703 \\
705 \\
407\end{array}$ & $\begin{array}{l}685 \\
694 \\
688 \\
545 \\
184\end{array}$ & $\begin{array}{l}695 \\
705 \\
698 \\
691 \\
253\end{array}$ & $\begin{array}{l}837 \\
831 \\
854 \\
887 \\
876\end{array}$ & $\begin{array}{l}805 \\
810 \\
828 \\
832 \\
840\end{array}$ & $\begin{array}{l}820 \\
819 \\
838 \\
867 \\
863\end{array}$ & $\begin{array}{l}709 \\
681 \\
831 \\
888 \\
778\end{array}$ & $\begin{array}{l}619 \\
653 \\
686 \\
722 \\
742\end{array}$ & $\begin{array}{l}645 \\
666 \\
752 \\
745 \\
757\end{array}$ & $\begin{array}{l}--- \\
--- \\
--- \\
---\end{array}$ & $\begin{array}{l}--- \\
--- \\
--- \\
---\end{array}$ & $\begin{array}{l}--- \\
--- \\
--- \\
--- \\
---\end{array}$ \\
\hline $\begin{array}{l}21 \\
22 \\
23 \\
24 \\
25\end{array}$ & $\begin{array}{l}293 \\
330 \\
357 \\
374 \\
408\end{array}$ & $\begin{array}{l}234 \\
293 \\
327 \\
356 \\
374\end{array}$ & $\begin{array}{l}263 \\
320 \\
346 \\
364 \\
389\end{array}$ & $\begin{array}{l}850 \\
862 \\
886 \\
896 \\
876\end{array}$ & $\begin{array}{l}841 \\
839 \\
862 \\
874 \\
819\end{array}$ & $\begin{array}{l}846 \\
849 \\
873 \\
886 \\
838\end{array}$ & $\begin{array}{l}778 \\
649 \\
898 \\
898 \\
908\end{array}$ & $\begin{array}{l}600 \\
579 \\
649 \\
831 \\
378\end{array}$ & $\begin{array}{l}698 \\
604 \\
730 \\
869 \\
677\end{array}$ & $\begin{array}{l}536 \\
518 \\
525 \\
646 \\
699\end{array}$ & $\begin{array}{l}437 \\
489 \\
517 \\
565 \\
644\end{array}$ & $\begin{array}{l}496 \\
504 \\
520 \\
616 \\
670\end{array}$ \\
\hline $\begin{array}{l}26 \\
27 \\
28 \\
29 \\
30 \\
31\end{array}$ & $\begin{array}{l}504 \\
384 \\
443 \\
--- \\
--- \\
---\end{array}$ & $\begin{array}{l}320 \\
348 \\
384 \\
--- \\
--- \\
---\end{array}$ & $\begin{array}{l}396 \\
368 \\
413 \\
--- \\
--- \\
---\end{array}$ & $\begin{array}{r}1160 \\
919 \\
826 \\
876 \\
888 \\
889\end{array}$ & $\begin{array}{l}869 \\
826 \\
798 \\
817 \\
842 \\
843\end{array}$ & $\begin{array}{l}975 \\
869 \\
806 \\
850 \\
874 \\
861\end{array}$ & $\begin{array}{l}814 \\
540 \\
628 \\
570 \\
627 \\
---\end{array}$ & $\begin{array}{l}432 \\
460 \\
472 \\
510 \\
570 \\
---\end{array}$ & $\begin{array}{l}509 \\
487 \\
505 \\
539 \\
594 \\
---\end{array}$ & $\begin{array}{l}839 \\
888 \\
697 \\
715 \\
601 \\
365\end{array}$ & $\begin{array}{l}634 \\
640 \\
591 \\
590 \\
221 \\
221\end{array}$ & $\begin{array}{l}709 \\
705 \\
613 \\
600 \\
403 \\
305\end{array}$ \\
\hline TH & 894 & 184 & 604 & 1160 & 443 & 765 & 1320 & 317 & 687 & -- & -- & --- \\
\hline
\end{tabular}


07330500 CADDO CREEK NEAR ARDMORE, OK--Continued

SPECIFIC CONDUCTANCE, US/CM @ 25 DEGREES CELSIUS, WATER YEAR OCTOBER 1996 TO SEPTEMBER 1997

\begin{tabular}{|c|c|c|c|c|c|c|c|c|c|c|c|c|}
\hline \multirow[t]{2}{*}{ DAY } & MAX & MIN & MEAN & MAX & MIN & MEAN & MAX & MIN & MEAN & MAX & MIN & MEAN \\
\hline & & JUNE & & \multicolumn{3}{|c|}{ JULY } & \multicolumn{3}{|c|}{ AUGUST } & \multicolumn{3}{|c|}{ SEPTEMBER } \\
\hline $\begin{array}{l}1 \\
2 \\
3 \\
4 \\
5\end{array}$ & $\begin{array}{l}447 \\
483 \\
566 \\
634 \\
744\end{array}$ & $\begin{array}{l}365 \\
447 \\
483 \\
566 \\
634\end{array}$ & $\begin{array}{l}412 \\
470 \\
522 \\
595 \\
691\end{array}$ & $\begin{array}{l}863 \\
906 \\
946 \\
939 \\
866\end{array}$ & $\begin{array}{l}820 \\
863 \\
906 \\
842 \\
729\end{array}$ & $\begin{array}{l}841 \\
883 \\
928 \\
902 \\
785\end{array}$ & $\begin{array}{l}556 \\
531 \\
529 \\
500 \\
492\end{array}$ & $\begin{array}{l}516 \\
520 \\
494 \\
476 \\
478\end{array}$ & $\begin{array}{l}537 \\
524 \\
516 \\
490 \\
486\end{array}$ & $\begin{array}{l}473 \\
455 \\
446 \\
431 \\
388\end{array}$ & $\begin{array}{l}446 \\
433 \\
425 \\
386 \\
373\end{array}$ & $\begin{array}{l}463 \\
447 \\
438 \\
414 \\
381\end{array}$ \\
\hline $\begin{array}{r}6 \\
7 \\
8 \\
9 \\
10\end{array}$ & $\begin{array}{l}786 \\
830 \\
845 \\
837 \\
390\end{array}$ & $\begin{array}{l}731 \\
782 \\
812 \\
281 \\
203\end{array}$ & $\begin{array}{l}762 \\
806 \\
831 \\
711 \\
290\end{array}$ & $\begin{array}{l}802 \\
817 \\
840 \\
876 \\
895\end{array}$ & $\begin{array}{l}718 \\
747 \\
761 \\
798 \\
774\end{array}$ & $\begin{array}{l}756 \\
779 \\
804 \\
854 \\
854\end{array}$ & $\begin{array}{l}501 \\
490 \\
456 \\
518 \\
524\end{array}$ & $\begin{array}{l}478 \\
425 \\
421 \\
446 \\
511\end{array}$ & $\begin{array}{l}493 \\
452 \\
441 \\
478 \\
518\end{array}$ & $\begin{array}{l}384 \\
392 \\
391 \\
399 \\
399\end{array}$ & $\begin{array}{l}375 \\
374 \\
378 \\
378 \\
381\end{array}$ & $\begin{array}{l}381 \\
383 \\
385 \\
391 \\
392\end{array}$ \\
\hline $\begin{array}{l}11 \\
12 \\
13 \\
14 \\
15\end{array}$ & $\begin{array}{l}362 \\
409 \\
454 \\
483 \\
469\end{array}$ & $\begin{array}{l}308 \\
369 \\
398 \\
429 \\
422\end{array}$ & $\begin{array}{l}342 \\
385 \\
405 \\
480 \\
442\end{array}$ & $\begin{array}{l}908 \\
898 \\
891 \\
892 \\
866\end{array}$ & $\begin{array}{l}816 \\
822 \\
851 \\
850 \\
824\end{array}$ & $\begin{array}{l}875 \\
881 \\
875 \\
866 \\
844\end{array}$ & $\begin{array}{l}524 \\
513 \\
484 \\
492 \\
505\end{array}$ & $\begin{array}{l}489 \\
484 \\
430 \\
440 \\
477\end{array}$ & $\begin{array}{l}507 \\
499 \\
459 \\
461 \\
491\end{array}$ & $\begin{array}{l}401 \\
405 \\
410 \\
402 \\
390\end{array}$ & $\begin{array}{l}381 \\
383 \\
386 \\
367 \\
374\end{array}$ & $\begin{array}{l}393 \\
396 \\
399 \\
389 \\
386\end{array}$ \\
\hline $\begin{array}{l}16 \\
17 \\
18 \\
19 \\
20\end{array}$ & $\begin{array}{r}531 \\
1030 \\
1330 \\
641 \\
689\end{array}$ & $\begin{array}{l}465 \\
504 \\
639 \\
622 \\
641\end{array}$ & $\begin{array}{l}487 \\
620 \\
762 \\
630 \\
662\end{array}$ & $\begin{array}{l}828 \\
784 \\
758 \\
680 \\
724\end{array}$ & $\begin{array}{l}713 \\
719 \\
586 \\
587 \\
680\end{array}$ & $\begin{array}{l}782 \\
764 \\
641 \\
639 \\
704\end{array}$ & $\begin{array}{l}495 \\
519 \\
522 \\
487 \\
418\end{array}$ & $\begin{array}{l}469 \\
495 \\
487 \\
404 \\
396\end{array}$ & $\begin{array}{l}482 \\
511 \\
510 \\
433 \\
407\end{array}$ & $\begin{array}{l}396 \\
404 \\
410 \\
415 \\
415\end{array}$ & $\begin{array}{l}382 \\
386 \\
389 \\
394 \\
386\end{array}$ & $\begin{array}{l}391 \\
396 \\
401 \\
404 \\
403\end{array}$ \\
\hline $\begin{array}{l}21 \\
22 \\
23 \\
24 \\
25\end{array}$ & $\begin{array}{l}734 \\
774 \\
977 \\
-- \\
853\end{array}$ & $\begin{array}{l}674 \\
731 \\
665 \\
--- \\
761\end{array}$ & $\begin{array}{l}707 \\
753 \\
867 \\
-- \\
821\end{array}$ & $\begin{array}{l}727 \\
706 \\
677 \\
675 \\
690\end{array}$ & $\begin{array}{l}696 \\
662 \\
657 \\
649 \\
641\end{array}$ & $\begin{array}{l}713 \\
679 \\
666 \\
655 \\
668\end{array}$ & $\begin{array}{l}493 \\
493 \\
451 \\
441 \\
430\end{array}$ & $\begin{array}{l}412 \\
419 \\
408 \\
404 \\
409\end{array}$ & $\begin{array}{l}456 \\
461 \\
430 \\
420 \\
420\end{array}$ & $\begin{array}{l}395 \\
384 \\
389 \\
378 \\
492\end{array}$ & $\begin{array}{l}374 \\
371 \\
344 \\
360 \\
367\end{array}$ & $\begin{array}{l}387 \\
378 \\
373 \\
370 \\
413\end{array}$ \\
\hline $\begin{array}{l}26 \\
27 \\
28 \\
29 \\
30 \\
31\end{array}$ & $\begin{array}{l}848 \\
837 \\
819 \\
816 \\
820 \\
---\end{array}$ & $\begin{array}{l}790 \\
763 \\
754 \\
769 \\
782 \\
---\end{array}$ & $\begin{array}{l}820 \\
798 \\
792 \\
791 \\
807 \\
---\end{array}$ & $\begin{array}{l}649 \\
629 \\
654 \\
647 \\
596 \\
544\end{array}$ & $\begin{array}{l}624 \\
610 \\
628 \\
595 \\
478 \\
474\end{array}$ & $\begin{array}{l}639 \\
621 \\
642 \\
629 \\
557 \\
507\end{array}$ & $\begin{array}{l}441 \\
458 \\
475 \\
478 \\
500 \\
490\end{array}$ & $\begin{array}{l}415 \\
430 \\
458 \\
460 \\
476 \\
463\end{array}$ & $\begin{array}{l}431 \\
448 \\
466 \\
470 \\
488 \\
481\end{array}$ & $\begin{array}{l}561 \\
561 \\
482 \\
456 \\
434 \\
---\end{array}$ & $\begin{array}{l}465 \\
470 \\
428 \\
425 \\
418 \\
---\end{array}$ & $\begin{array}{l}494 \\
506 \\
456 \\
445 \\
427 \\
---\end{array}$ \\
\hline $\mathrm{NTH}$ & -- & -- & $\ldots$ & 946 & 474 & 749 & 556 & 396 & 473 & 561 & 344 & 409 \\
\hline
\end{tabular}


07330500 CADDO CREEK NEAR ARDMORE, OK--Continued

PH, WATER, WHOLE, FIELD, STANDARD UNITS, WATER YEAR OCTOBER 1996 TO SEPTEMBER 1997

\begin{tabular}{|c|c|c|c|c|c|c|c|c|c|c|c|c|}
\hline \multirow[t]{2}{*}{ DAY } & MAX & MIN & MEDIAN & MAX & MIN & MEDIAN & MAX & MIN & MEDIAN & $\operatorname{MAX}$ & MIN & MEDIAN \\
\hline & \multicolumn{3}{|c|}{ OCTOBER } & \multicolumn{3}{|c|}{ NOVEMBER } & \multicolumn{3}{|c|}{ DECEMBER } & \multicolumn{3}{|c|}{ JANUARY } \\
\hline $\begin{array}{l}1 \\
2 \\
3 \\
4 \\
5\end{array}$ & $\begin{array}{l}8.5 \\
8.5 \\
8.5 \\
8.5 \\
8.5\end{array}$ & $\begin{array}{l}8.3 \\
8.4 \\
8.5 \\
8.5 \\
8.4\end{array}$ & $\begin{array}{l}8.4 \\
8.5 \\
8.5 \\
8.5 \\
8.4\end{array}$ & $\begin{array}{l}--- \\
--. \\
--- \\
-\overline{8.5}\end{array}$ & $\begin{array}{l}--- \\
-- \\
--- \\
-- \\
8.4\end{array}$ & $\begin{array}{l}--- \\
--- \\
--- \\
-8.4\end{array}$ & $\begin{array}{l}8.3 \\
8.3 \\
8.4 \\
8.5 \\
8.8\end{array}$ & $\begin{array}{l}8.2 \\
8.3 \\
8.3 \\
8.4 \\
8.4\end{array}$ & $\begin{array}{l}8.3 \\
8.3 \\
8.4 \\
8.4 \\
8.5\end{array}$ & $\begin{array}{l}8.6 \\
8.5 \\
8.4 \\
8.4 \\
8.4\end{array}$ & $\begin{array}{l}8.4 \\
8.3 \\
8.3 \\
8.3 \\
8.3\end{array}$ & $\begin{array}{l}8.5 \\
8.4 \\
8.3 \\
8.3 \\
8.3\end{array}$ \\
\hline $\begin{array}{r}6 \\
7 \\
8 \\
9 \\
10\end{array}$ & $\begin{array}{l}8.4 \\
8.4 \\
8.6 \\
8.5 \\
8.6\end{array}$ & $\begin{array}{l}8.4 \\
8.4 \\
8.4 \\
8.5 \\
8.5\end{array}$ & $\begin{array}{l}8.4 \\
8.4 \\
8.5 \\
8.5 \\
8.5\end{array}$ & $\begin{array}{l}8.5 \\
8.4 \\
8.1 \\
8.2 \\
8.3\end{array}$ & $\begin{array}{l}8.4 \\
8.0 \\
8.0 \\
7.8 \\
8.2\end{array}$ & $\begin{array}{l}8.4 \\
8.1 \\
8.1 \\
7.9 \\
8.3\end{array}$ & $\begin{array}{l}8.5 \\
8.5 \\
8.5 \\
8.5 \\
8.6\end{array}$ & $\begin{array}{l}8.4 \\
8.5 \\
8.5 \\
8.5 \\
8.5\end{array}$ & $\begin{array}{l}8.5 \\
8.5 \\
8.5 \\
8.5 \\
8.5\end{array}$ & $\begin{array}{l}8.4 \\
8.3 \\
8.3 \\
8.3 \\
8.3\end{array}$ & $\begin{array}{l}8.3 \\
8.3 \\
8.3 \\
8.3 \\
8.3\end{array}$ & $\begin{array}{l}8.3 \\
8.3 \\
8.3 \\
8.3 \\
8.3\end{array}$ \\
\hline $\begin{array}{l}11 \\
12 \\
13 \\
14 \\
15\end{array}$ & $\begin{array}{l}8.6 \\
8.6 \\
8.6 \\
8.5 \\
8.5\end{array}$ & $\begin{array}{l}8.5 \\
8.5 \\
8.5 \\
8.5 \\
8.5\end{array}$ & $\begin{array}{l}8.6 \\
8.6 \\
8.5 \\
8.5 \\
8.5\end{array}$ & $\begin{array}{l}8.3 \\
8.4 \\
8.4 \\
8.4 \\
8.4\end{array}$ & $\begin{array}{l}8.3 \\
8.3 \\
8.3 \\
8.3 \\
8.3\end{array}$ & $\begin{array}{l}8.3 \\
8.3 \\
8.4 \\
8.4 \\
8.3\end{array}$ & $\begin{array}{c}8.6 \\
8.6 \\
--- \\
--- \\
--\end{array}$ & $\begin{array}{l}8.5 \\
8.6 \\
--- \\
---\end{array}$ & $\begin{array}{l}8.5 \\
8.6 \\
--- \\
---\end{array}$ & $\begin{array}{l}8.3 \\
8.3 \\
8.3 \\
8.2 \\
8.3\end{array}$ & $\begin{array}{l}8.3 \\
8.2 \\
8.2 \\
8.2 \\
8.2\end{array}$ & $\begin{array}{l}8.3 \\
8.3 \\
8.2 \\
8.2 \\
8.2\end{array}$ \\
\hline $\begin{array}{l}16 \\
17 \\
18 \\
19 \\
20\end{array}$ & $\begin{array}{l}8.5 \\
8.5 \\
8.6 \\
8.6 \\
8.6\end{array}$ & $\begin{array}{l}8.5 \\
8.5 \\
8.5 \\
8.6 \\
8.5\end{array}$ & $\begin{array}{l}8.5 \\
8.5 \\
8.5 \\
8.6 \\
8.5\end{array}$ & $\begin{array}{l}8.3 \\
8.1 \\
8.0 \\
8.0 \\
8.1\end{array}$ & $\begin{array}{l}8.1 \\
7.7 \\
7.9 \\
7.9 \\
8.0\end{array}$ & $\begin{array}{l}8.2 \\
7.8 \\
7.9 \\
8.0 \\
8.0\end{array}$ & $\begin{array}{l}8.7 \\
8.7 \\
8.7 \\
8.7 \\
8.6\end{array}$ & $\begin{array}{l}8.6 \\
8.6 \\
8.6 \\
8.6 \\
8.5\end{array}$ & $\begin{array}{l}8.6 \\
8.7 \\
8.7 \\
8.6 \\
8.6\end{array}$ & $\begin{array}{l}8.3 \\
8.3 \\
8.3 \\
8.3 \\
8.3\end{array}$ & $\begin{array}{l}8.3 \\
8.2 \\
8.2 \\
8.3 \\
8.3\end{array}$ & $\begin{array}{l}8.3 \\
8.3 \\
8.3 \\
8.3 \\
8.3\end{array}$ \\
\hline $\begin{array}{l}21 \\
22 \\
23 \\
24 \\
25\end{array}$ & $\begin{array}{l}8.5 \\
8.3 \\
8.4 \\
8.5 \\
8.4\end{array}$ & $\begin{array}{l}8.1 \\
8.2 \\
8.3 \\
8.4 \\
8.4\end{array}$ & $\begin{array}{l}8.2 \\
8.2 \\
8.4 \\
8.4 \\
8.4\end{array}$ & $\begin{array}{l}8.1 \\
8.2 \\
8.3 \\
8.3 \\
8.0\end{array}$ & $\begin{array}{l}8.1 \\
8.1 \\
8.2 \\
7.9 \\
7.9\end{array}$ & $\begin{array}{l}8.1 \\
8.2 \\
8.3 \\
7.9 \\
8.0\end{array}$ & $\begin{array}{l}8.5 \\
--- \\
--- \\
--- \\
---\end{array}$ & $\begin{array}{c}8.5 \\
--- \\
--- \\
--- \\
---\end{array}$ & $\begin{array}{l}8.5 \\
--- \\
--- \\
--- \\
---\end{array}$ & $\begin{array}{l}8.4 \\
8.4 \\
8.4 \\
8.4 \\
8.4\end{array}$ & $\begin{array}{l}8.3 \\
8.3 \\
8.3 \\
8.3 \\
8.3\end{array}$ & $\begin{array}{l}8.3 \\
8.3 \\
8.3 \\
8.3 \\
8.3\end{array}$ \\
\hline $\begin{array}{l}26 \\
27 \\
28 \\
29 \\
30 \\
31\end{array}$ & $\begin{array}{l}8.5 \\
8.4 \\
8.4 \\
8.4 \\
---\end{array}$ & $\begin{array}{l}8.3 \\
8.3 \\
8.4 \\
8.3 \\
---\end{array}$ & $\begin{array}{l}8.4 \\
8.3 \\
8.4 \\
8.3 \\
--- \\
---\end{array}$ & $\begin{array}{r}8.1 \\
8.2 \\
8.2 \\
8.2 \\
8.2 \\
---\end{array}$ & $\begin{array}{r}8.0 \\
8.1 \\
8.2 \\
8.0 \\
8.0 \\
---\end{array}$ & $\begin{array}{r}8.1 \\
8.1 \\
8.2 \\
8.0 \\
8.0 \\
---\end{array}$ & $\begin{array}{l}--- \\
--- \\
--- \\
--- \\
-8.5\end{array}$ & $\begin{array}{l}--- \\
--- \\
--- \\
--- \\
-8.4\end{array}$ & $\begin{array}{l}--- \\
--- \\
--- \\
--- \\
-- \\
8.5\end{array}$ & $\begin{array}{l}8.4 \\
8.4 \\
8.4 \\
8.3 \\
8.3 \\
8.3\end{array}$ & $\begin{array}{l}8.3 \\
8.3 \\
8.3 \\
8.3 \\
8.3 \\
8.3\end{array}$ & $\begin{array}{l}8.3 \\
8.3 \\
8.4 \\
8.3 \\
8.3 \\
8.3\end{array}$ \\
\hline $\begin{array}{l}\text { MAX } \\
\text { MIN }\end{array}$ & - & -- & --- & --- & $\begin{array}{l}--- \\
---\end{array}$ & -- & --- & --- & $\cdots$ & $\begin{array}{l}8.6 \\
8.2\end{array}$ & $\begin{array}{l}8.4 \\
8.2\end{array}$ & $\begin{array}{l}8.5 \\
8.2\end{array}$ \\
\hline
\end{tabular}




\section{CADDO CREEK NEAR ARDMORE, OK--Continued}

PH, WATER, WHOLE, FIELD, STANDARD UNITS, WATER YEAR OCTOBER 1996 TO SEPTEMBER 1997

\begin{tabular}{|c|c|c|c|c|c|c|c|c|c|c|c|c|}
\hline \multirow[t]{2}{*}{ DAY } & $\operatorname{MAX}$ & MIN & MEDIAN & MAX & MIN & MEDIAN & MAX & MIN & MEDIAN & MAX & MIN & MEDIAN \\
\hline & \multicolumn{3}{|c|}{ FEBRUARY } & \multicolumn{3}{|c|}{ MARCH } & \multicolumn{3}{|c|}{ APRIL } & \multicolumn{3}{|c|}{ MAY } \\
\hline $\begin{array}{l}1 \\
2 \\
3 \\
4 \\
5\end{array}$ & $\begin{array}{l}8.4 \\
8.4 \\
8.4 \\
8.4 \\
8.4\end{array}$ & $\begin{array}{l}8.3 \\
8.3 \\
8.3 \\
8.3 \\
8.3\end{array}$ & $\begin{array}{l}8.3 \\
8.3 \\
8.3 \\
8.3 \\
8.3\end{array}$ & $\begin{array}{l}8.2 \\
8.3 \\
8.3 \\
8.3 \\
8.4\end{array}$ & $\begin{array}{l}8.2 \\
8.2 \\
8.1 \\
8.3 \\
8.3\end{array}$ & $\begin{array}{l}8.2 \\
8.3 \\
8.3 \\
8.3 \\
8.4\end{array}$ & $\begin{array}{l}8.3 \\
8.3 \\
8.3 \\
8.2 \\
8.2\end{array}$ & $\begin{array}{l}8.3 \\
8.2 \\
8.2 \\
8.1 \\
8.0\end{array}$ & $\begin{array}{l}8.3 \\
8.3 \\
8.2 \\
8.2 \\
8.0\end{array}$ & $\begin{array}{c}8.4 \\
--- \\
-- \\
--- \\
---\end{array}$ & $\begin{array}{l}8.4 \\
--- \\
-- \\
--- \\
---\end{array}$ & $\begin{array}{c}8.4 \\
--- \\
--- \\
--- \\
---\end{array}$ \\
\hline $\begin{array}{r}6 \\
7 \\
8 \\
9 \\
10\end{array}$ & $\begin{array}{l}8.3 \\
8.3 \\
8.2 \\
8.3 \\
8.4\end{array}$ & $\begin{array}{l}8.3 \\
8.1 \\
8.2 \\
8.2 \\
8.3\end{array}$ & $\begin{array}{l}8.3 \\
8.2 \\
8.2 \\
8.3 \\
8.3\end{array}$ & $\begin{array}{l}8.4 \\
8.4 \\
8.4 \\
8.4 \\
8.4\end{array}$ & $\begin{array}{l}8.4 \\
8.3 \\
8.4 \\
8.4 \\
8.4\end{array}$ & $\begin{array}{l}8.4 \\
8.4 \\
8.4 \\
8.4 \\
8.4\end{array}$ & $\begin{array}{l}8.2 \\
8.3 \\
8.3 \\
8.4 \\
8.4\end{array}$ & $\begin{array}{l}8.1 \\
8.2 \\
8.3 \\
8.3 \\
8.3\end{array}$ & $\begin{array}{l}8.2 \\
8.3 \\
8.3 \\
8.3 \\
8.3\end{array}$ & $\begin{array}{l}--- \\
--- \\
--- \\
---\end{array}$ & $\begin{array}{l}--- \\
--- \\
--- \\
--- \\
---\end{array}$ & $\begin{array}{l}--- \\
--- \\
--- \\
---\end{array}$ \\
\hline $\begin{array}{l}11 \\
12 \\
13 \\
14 \\
15\end{array}$ & $\begin{array}{l}8.4 \\
8.4 \\
8.4 \\
8.5 \\
8.5\end{array}$ & $\begin{array}{l}8.4 \\
8.4 \\
8.4 \\
8.4 \\
8.4\end{array}$ & $\begin{array}{l}8.4 \\
8.4 \\
8.4 \\
8.4 \\
8.4\end{array}$ & $\begin{array}{l}8.4 \\
8.5 \\
8.4 \\
8.4 \\
8.4\end{array}$ & $\begin{array}{l}8.3 \\
8.4 \\
8.3 \\
8.4 \\
8.3\end{array}$ & $\begin{array}{l}8.4 \\
8.4 \\
8.4 \\
8.4 \\
8.3\end{array}$ & $\begin{array}{l}8.3 \\
8.0 \\
8.1 \\
8.2 \\
8.2\end{array}$ & $\begin{array}{l}7.8 \\
7.9 \\
8.0 \\
8.1 \\
8.2\end{array}$ & $\begin{array}{l}8.0 \\
8.0 \\
8.1 \\
8.1 \\
8.2\end{array}$ & $\begin{array}{l}--- \\
--- \\
--- \\
---\end{array}$ & $\begin{array}{l}\cdots- \\
\cdots- \\
--- \\
--\end{array}$ & $\begin{array}{l}--- \\
--- \\
--- \\
---\end{array}$ \\
\hline $\begin{array}{l}16 \\
17 \\
18 \\
19 \\
20\end{array}$ & $\begin{array}{l}8.5 \\
8.5 \\
8.5 \\
8.5 \\
8.1\end{array}$ & $\begin{array}{l}8.4 \\
8.4 \\
8.4 \\
8.3 \\
7.4\end{array}$ & $\begin{array}{l}8.4 \\
8.4 \\
8.5 \\
8.4 \\
8.0\end{array}$ & $\begin{array}{r}8.4 \\
8.4 \\
8.4 \\
--\end{array}$ & $\begin{array}{l}8.3 \\
8.3 \\
8.3 \\
--- \\
--\end{array}$ & $\begin{array}{c}8.3 \\
8.3 \\
8.3 \\
--- \\
---\end{array}$ & $\begin{array}{l}8.3 \\
8.3 \\
8.4 \\
8.5 \\
8.5\end{array}$ & $\begin{array}{l}8.2 \\
8.3 \\
8.3 \\
8.3 \\
8.3\end{array}$ & $\begin{array}{l}8.2 \\
8.3 \\
8.3 \\
8.4 \\
8.3\end{array}$ & $\begin{array}{l}--- \\
--- \\
--- \\
---\end{array}$ & $\begin{array}{l}-- \\
--- \\
--- \\
---\end{array}$ & $\begin{array}{l}--- \\
--- \\
--- \\
---\end{array}$ \\
\hline $\begin{array}{l}21 \\
22 \\
23 \\
24 \\
25\end{array}$ & $\begin{array}{l}8.1 \\
8.1 \\
8.1 \\
8.1 \\
8.2\end{array}$ & $\begin{array}{l}8.0 \\
8.1 \\
7.9 \\
8.1 \\
8.1\end{array}$ & $\begin{array}{l}8.0 \\
8.1 \\
8.1 \\
8.1 \\
8.1\end{array}$ & $\begin{array}{l}--- \\
--- \\
--- \\
-- \\
8.4\end{array}$ & $\begin{array}{l}--- \\
--- \\
--- \\
-\overline{8.3}\end{array}$ & $\begin{array}{l}--- \\
-\cdots \\
--- \\
-\overline{8.3}\end{array}$ & $\begin{array}{l}8.5 \\
8.3 \\
8.4 \\
8.4 \\
8.4\end{array}$ & $\begin{array}{l}8.3 \\
8.3 \\
8.3 \\
8.3 \\
8.0\end{array}$ & $\begin{array}{l}8.3 \\
8.3 \\
8.3 \\
8.3 \\
8.3\end{array}$ & $\begin{array}{l}8.2 \\
8.2 \\
8.2 \\
8.3 \\
8.4\end{array}$ & $\begin{array}{l}8.1 \\
8.2 \\
8.2 \\
8.3 \\
8.3\end{array}$ & $\begin{array}{l}8.1 \\
8.2 \\
8.2 \\
8.3 \\
8.3\end{array}$ \\
\hline $\begin{array}{l}26 \\
27 \\
28 \\
29 \\
30 \\
31\end{array}$ & $\begin{array}{l}8.2 \\
8.2 \\
8.2 \\
-- \\
---\end{array}$ & $\begin{array}{l}8.0 \\
8.1 \\
8.2 \\
--- \\
--- \\
---\end{array}$ & $\begin{array}{c}8.1 \\
8.1 \\
8.2 \\
--- \\
--- \\
---\end{array}$ & $\begin{array}{l}8.3 \\
8.4 \\
8.4 \\
8.3 \\
8.3 \\
8.3\end{array}$ & $\begin{array}{l}8.3 \\
8.3 \\
8.3 \\
8.3 \\
8.3 \\
8.3\end{array}$ & $\begin{array}{l}8.3 \\
8.3 \\
8.3 \\
8.3 \\
8.3 \\
8.3\end{array}$ & $\begin{array}{r}8.2 \\
8.2 \\
8.2 \\
8.3 \\
8.4 \\
--\end{array}$ & $\begin{array}{r}8.0 \\
8.1 \\
8.1 \\
8.1 \\
8.3 \\
---\end{array}$ & $\begin{array}{r}8.1 \\
8.2 \\
8.2 \\
8.2 \\
8.3 \\
--\end{array}$ & $\begin{array}{l}8.4 \\
8.3 \\
8.7 \\
8.5 \\
8.4 \\
8.0\end{array}$ & $\begin{array}{l}8.3 \\
8.2 \\
8.3 \\
8.4 \\
8.0 \\
7.9\end{array}$ & $\begin{array}{l}8.3 \\
8.3 \\
8.4 \\
8.4 \\
8.2 \\
7.9\end{array}$ \\
\hline $\begin{array}{l}\mathrm{X} \\
\mathrm{N}\end{array}$ & $\begin{array}{l}8.5 \\
8.1\end{array}$ & $\begin{array}{l}8.4 \\
7.4\end{array}$ & $\begin{array}{l}8.5 \\
8.0\end{array}$ & --- & --- & --- & $\begin{array}{l}8.5 \\
8.0\end{array}$ & $\begin{array}{l}8.3 \\
7.8\end{array}$ & $\begin{array}{l}8.4 \\
8.0\end{array}$ & --- & -- & -- \\
\hline
\end{tabular}


07330500 CADDO CREEK NEAR ARDMORE, OK--Continued

PH, WATER, WHOLE, FIELD, STANDARD UNITS, WATER YEAR OCTOBER 1996 TO SEPTEMBER 1997

\begin{tabular}{|c|c|c|c|c|c|c|c|c|c|c|c|c|}
\hline \multirow[t]{2}{*}{ DAY } & MAX & MIN & MEDIAN & MAX & MIN & MEDIAN & MAX & MIN & MEDIAN & MAX & MIN & MEDIAN \\
\hline & \multicolumn{3}{|c|}{ JUNE } & \multicolumn{3}{|c|}{ JULY } & \multicolumn{3}{|c|}{ AUGUST } & \multicolumn{3}{|c|}{ SEPTEMBER } \\
\hline $\begin{array}{l}1 \\
2 \\
3 \\
4 \\
5\end{array}$ & $\begin{array}{l}8.0 \\
8.1 \\
8.2 \\
8.3 \\
8.3\end{array}$ & $\begin{array}{l}7.9 \\
8.0 \\
8.1 \\
8.2 \\
8.2\end{array}$ & $\begin{array}{l}7.9 \\
8.0 \\
8.1 \\
8.2 \\
8.2\end{array}$ & $\begin{array}{l}8.3 \\
8.3 \\
8.3 \\
8.3 \\
8.4\end{array}$ & $\begin{array}{l}8.2 \\
8.2 \\
8.2 \\
8.2 \\
8.2\end{array}$ & $\begin{array}{l}8.2 \\
8.2 \\
8.2 \\
8.3 \\
8.3\end{array}$ & $\begin{array}{l}8.5 \\
8.4 \\
8.4 \\
8.4 \\
8.4\end{array}$ & $\begin{array}{l}8.1 \\
8.1 \\
8.1 \\
8.1 \\
8.1\end{array}$ & $\begin{array}{l}8.3 \\
8.3 \\
8.2 \\
8.2 \\
8.2\end{array}$ & $\begin{array}{l}8.9 \\
8.8 \\
8.8 \\
8.6 \\
8.8\end{array}$ & $\begin{array}{l}8.2 \\
8.1 \\
8.0 \\
8.0 \\
8.1\end{array}$ & $\begin{array}{l}8.5 \\
8.4 \\
8.3 \\
8.2 \\
8.4\end{array}$ \\
\hline $\begin{array}{r}6 \\
7 \\
8 \\
9 \\
10\end{array}$ & $\begin{array}{l}8.3 \\
8.4 \\
8.3 \\
8.3 \\
7.8\end{array}$ & $\begin{array}{l}8.2 \\
8.2 \\
8.2 \\
7.8 \\
7.7\end{array}$ & $\begin{array}{l}8.2 \\
8.3 \\
8.3 \\
8.3 \\
7.8\end{array}$ & $\begin{array}{l}8.3 \\
8.4 \\
8.3 \\
8.3 \\
8.3\end{array}$ & $\begin{array}{l}8.2 \\
8.2 \\
8.2 \\
8.2 \\
8.2\end{array}$ & $\begin{array}{l}8.3 \\
8.3 \\
8.3 \\
8.3 \\
8.3\end{array}$ & $\begin{array}{l}8.5 \\
8.4 \\
8.6 \\
8.5 \\
8.5\end{array}$ & $\begin{array}{l}8.1 \\
8.2 \\
8.2 \\
8.1 \\
8.1\end{array}$ & $\begin{array}{l}8.2 \\
8.3 \\
8.3 \\
8.3 \\
8.3\end{array}$ & $\begin{array}{l}8.8 \\
8.8 \\
8.8 \\
8.9 \\
8.9\end{array}$ & $\begin{array}{l}8.2 \\
8.1 \\
8.1 \\
8.1 \\
8.2\end{array}$ & $\begin{array}{l}8.5 \\
8.5 \\
8.4 \\
8.3 \\
8.4\end{array}$ \\
\hline $\begin{array}{l}11 \\
12 \\
13 \\
14 \\
15\end{array}$ & $\begin{array}{l}8.0 \\
8.1 \\
8.1 \\
8.2 \\
8.3\end{array}$ & $\begin{array}{l}7.8 \\
8.0 \\
8.1 \\
8.1 \\
8.2\end{array}$ & $\begin{array}{l}7.8 \\
8.0 \\
8.1 \\
8.2 \\
8.2\end{array}$ & $\begin{array}{l}8.3 \\
8.3 \\
8.3 \\
8.3 \\
8.4\end{array}$ & $\begin{array}{l}8.2 \\
8.2 \\
8.2 \\
8.2 \\
8.2\end{array}$ & $\begin{array}{l}8.3 \\
8.3 \\
8.2 \\
8.2 \\
8.3\end{array}$ & $\begin{array}{l}8.5 \\
8.5 \\
8.5 \\
8.5 \\
8.6\end{array}$ & $\begin{array}{l}8.1 \\
8.1 \\
8.1 \\
8.1 \\
8.2\end{array}$ & $\begin{array}{l}8.3 \\
8.3 \\
8.3 \\
8.3 \\
8.4\end{array}$ & $\begin{array}{l}8.9 \\
8.9 \\
8.9 \\
8.9 \\
8.8\end{array}$ & $\begin{array}{l}8.2 \\
8.1 \\
8.1 \\
8.2 \\
8.1\end{array}$ & $\begin{array}{l}8.5 \\
8.5 \\
8.5 \\
8.5 \\
8.4\end{array}$ \\
\hline $\begin{array}{l}16 \\
17 \\
18 \\
19 \\
20\end{array}$ & $\begin{array}{l}8.3 \\
8.4 \\
8.2 \\
8.4 \\
8.5\end{array}$ & $\begin{array}{l}8.3 \\
8.3 \\
8.1 \\
8.2 \\
8.4\end{array}$ & $\begin{array}{l}8.3 \\
8.3 \\
8.2 \\
8.3 \\
8.4\end{array}$ & $\begin{array}{l}8.4 \\
8.4 \\
8.4 \\
8.4 \\
8.4\end{array}$ & $\begin{array}{l}8.2 \\
8.2 \\
8.2 \\
8.1 \\
8.2\end{array}$ & $\begin{array}{l}8.3 \\
8.3 \\
8.3 \\
8.3 \\
8.3\end{array}$ & $\begin{array}{l}8.6 \\
8.7 \\
8.5 \\
8.6 \\
8.6\end{array}$ & $\begin{array}{l}8.1 \\
8.1 \\
8.0 \\
8.1 \\
8.1\end{array}$ & $\begin{array}{l}8.3 \\
8.2 \\
8.2 \\
8.3 \\
8.3\end{array}$ & $\begin{array}{l}8.9 \\
8.9 \\
8.9 \\
8.8 \\
9.0\end{array}$ & $\begin{array}{l}8.1 \\
8.1 \\
8.1 \\
8.1 \\
8.1\end{array}$ & $\begin{array}{l}8.4 \\
8.4 \\
8.4 \\
8.5 \\
8.5\end{array}$ \\
\hline $\begin{array}{l}21 \\
22 \\
23 \\
24 \\
25\end{array}$ & $\begin{array}{r}8.5 \\
8.5 \\
8.4 \\
- \\
8.3\end{array}$ & $\begin{array}{r}8.4 \\
8.4 \\
8.2 \\
-- \\
8.2\end{array}$ & $\begin{array}{r}8.5 \\
8.4 \\
8.3 \\
-- \\
8.2\end{array}$ & $\begin{array}{l}8.4 \\
8.4 \\
8.4 \\
8.3 \\
8.3\end{array}$ & $\begin{array}{l}8.2 \\
8.2 \\
8.2 \\
8.1 \\
8.0\end{array}$ & $\begin{array}{l}8.3 \\
8.3 \\
8.3 \\
8.2 \\
8.1\end{array}$ & $\begin{array}{l}8.6 \\
8.5 \\
8.7 \\
8.7 \\
8.8\end{array}$ & $\begin{array}{l}8.1 \\
8.1 \\
8.1 \\
8.1 \\
8.2\end{array}$ & $\begin{array}{l}8.4 \\
8.3 \\
8.4 \\
8.4 \\
8.5\end{array}$ & $\begin{array}{l}8.9 \\
9.0 \\
8.7 \\
8.8 \\
8.5\end{array}$ & $\begin{array}{l}8.2 \\
8.1 \\
8.1 \\
8.1 \\
8.1\end{array}$ & $\begin{array}{l}8.5 \\
8.4 \\
8.4 \\
8.4 \\
8.3\end{array}$ \\
\hline $\begin{array}{l}26 \\
27 \\
28 \\
29 \\
30 \\
31\end{array}$ & $\begin{array}{r}8.3 \\
8.3 \\
8.3 \\
8.3 \\
8.3 \\
-\end{array}$ & $\begin{array}{r}8.2 \\
8.2 \\
8.2 \\
8.2 \\
8.2 \\
---\end{array}$ & $\begin{array}{r}8.2 \\
8.2 \\
8.2 \\
8.2 \\
8.2 \\
---\end{array}$ & $\begin{array}{l}8.3 \\
8.3 \\
8.3 \\
8.3 \\
8.4 \\
8.4\end{array}$ & $\begin{array}{l}8.0 \\
8.0 \\
8.0 \\
8.0 \\
8.0 \\
8.0\end{array}$ & $\begin{array}{l}8.1 \\
8.1 \\
8.1 \\
8.1 \\
8.1 \\
8.2\end{array}$ & $\begin{array}{l}8.8 \\
8.9 \\
8.8 \\
8.8 \\
8.9 \\
8.9\end{array}$ & $\begin{array}{l}8.2 \\
8.2 \\
8.2 \\
8.1 \\
8.2 \\
8.2\end{array}$ & $\begin{array}{l}8.5 \\
8.5 \\
8.5 \\
8.5 \\
8.5 \\
8.4\end{array}$ & $\begin{array}{r}8.4 \\
8.5 \\
8.6 \\
8.6 \\
8.7 \\
---\end{array}$ & $\begin{array}{r}7.8 \\
7.8 \\
7.9 \\
7.9 \\
7.8 \\
---\end{array}$ & $\begin{array}{r}8.1 \\
8.1 \\
8.2 \\
8.2 \\
8.1 \\
---\end{array}$ \\
\hline IAX & $-\cdots$ & --- & --- & $\begin{array}{l}8.4 \\
8.3\end{array}$ & $\begin{array}{l}8.2 \\
8.0\end{array}$ & $\begin{array}{l}8.3 \\
8.1\end{array}$ & $\begin{array}{l}8.9 \\
8.4\end{array}$ & $\begin{array}{l}8.2 \\
8.0\end{array}$ & $\begin{array}{l}8.5 \\
8.2\end{array}$ & $\begin{array}{l}9.0 \\
8.4\end{array}$ & $\begin{array}{l}8.2 \\
7.8\end{array}$ & $\begin{array}{l}8.5 \\
8.1\end{array}$ \\
\hline
\end{tabular}


07330500 CADDO CREEK NEAR ARDMORE, OK--Continued

WATER TEMPERATURE, DEGREES CELSIUS, WATER YEAR OCTOBER 1996 TO SEPTEMBER 1997 MAX MIN MEAN

MAX MIN

MEAN

MAX MIN MEAN

MAX MIN

MEAN

NOVEMBER

DECEMBER

JANUARY

\begin{tabular}{|c|c|c|c|c|c|c|c|c|c|c|c|}
\hline $\begin{array}{l}21.0 \\
22.0 \\
21.5 \\
21.0 \\
21.5\end{array}$ & $\begin{array}{l}17.5 \\
17.0 \\
19.0 \\
18.5 \\
18.5\end{array}$ & $\begin{array}{l}19.5 \\
20.0 \\
20.0 \\
19.5 \\
20.0\end{array}$ & $\begin{array}{l}13.5 \\
12.0 \\
11.5 \\
14.0 \\
16.5\end{array}$ & $\begin{array}{r}11.0 \\
9.0 \\
9.0 \\
10.5 \\
12.0\end{array}$ & $\begin{array}{l}12.0 \\
11.0 \\
10.5 \\
12.0 \\
14.5\end{array}$ & $\begin{array}{l}8.5 \\
9.0 \\
9.0 \\
8.0 \\
9.0\end{array}$ & $\begin{array}{l}7.5 \\
7.0 \\
7.5 \\
6.5 \\
7.0\end{array}$ & $\begin{array}{l}8.0 \\
8.0 \\
8.0 \\
7.0 \\
8.0\end{array}$ & $\begin{array}{l}13.5 \\
14.5 \\
17.0 \\
16.5 \\
13.0\end{array}$ & $\begin{array}{r}11.0 \\
11.5 \\
13.0 \\
13.0 \\
9.0\end{array}$ & $\begin{array}{l}12.0 \\
12.5 \\
15.0 \\
15.5 \\
11.0\end{array}$ \\
\hline $\begin{array}{l}22.5 \\
23.0 \\
22.5 \\
21.0 \\
20.5\end{array}$ & $\begin{array}{l}19.0 \\
18.5 \\
19.5 \\
16.5 \\
16.5\end{array}$ & $\begin{array}{l}20.5 \\
21.0 \\
21.0 \\
19.0 \\
18.5\end{array}$ & $\begin{array}{l}19.5 \\
16.5 \\
13.0 \\
12.5 \\
12.0\end{array}$ & $\begin{array}{r}16.5 \\
12.5 \\
11.0 \\
9.0 \\
10.0\end{array}$ & $\begin{array}{l}17.5 \\
13.5 \\
12.0 \\
11.0 \\
11.0\end{array}$ & $\begin{array}{r}10.0 \\
10.0 \\
9.5 \\
10.5 \\
13.5\end{array}$ & $\begin{array}{r}8.0 \\
8.5 \\
7.0 \\
7.0 \\
10.0\end{array}$ & $\begin{array}{r}9.0 \\
9.5 \\
8.5 \\
9.0 \\
11.5\end{array}$ & $\begin{array}{l}9.0 \\
5.0 \\
4.0 \\
5.5 \\
5.0\end{array}$ & $\begin{array}{l}5.0 \\
3.5 \\
3.0 \\
2.5 \\
1.5\end{array}$ & $\begin{array}{l}7.0 \\
4.0 \\
3.5 \\
4.0 \\
3.0\end{array}$ \\
\hline $\begin{array}{l}20.5 \\
22.0 \\
23.5 \\
23.0 \\
23.5\end{array}$ & $\begin{array}{l}16.5 \\
16.5 \\
18.0 \\
17.0 \\
18.0\end{array}$ & $\begin{array}{l}18.0 \\
19.0 \\
20.0 \\
19.5 \\
20.0\end{array}$ & $\begin{array}{l}12.5 \\
12.5 \\
12.5 \\
15.5 \\
15.5\end{array}$ & $\begin{array}{r}9.5 \\
10.5 \\
10.0 \\
12.0 \\
14.5\end{array}$ & $\begin{array}{l}11.0 \\
11.0 \\
11.0 \\
14.0 \\
15.0\end{array}$ & $\begin{array}{l}13.5 \\
13.0 \\
12.5 \\
--- \\
---\end{array}$ & $\begin{array}{r}11.0 \\
10.0 \\
9.5 \\
--- \\
---\end{array}$ & $\begin{array}{l}12.5 \\
11.5 \\
11.0 \\
--- \\
---\end{array}$ & $\begin{array}{r}1.5 \\
.0 \\
.0 \\
.0 \\
2.5\end{array}$ & $\begin{array}{l}.0 \\
.0 \\
.0 \\
.0 \\
.0\end{array}$ & $\begin{array}{r}.5 \\
.0 \\
.0 \\
.0 \\
1.0\end{array}$ \\
\hline $\begin{array}{l}25.0 \\
22.5 \\
19.0 \\
16.5 \\
20.0\end{array}$ & $\begin{array}{l}19.5 \\
17.0 \\
13.5 \\
12.0 \\
13.5\end{array}$ & $\begin{array}{l}21.5 \\
20.5 \\
16.0 \\
14.0 \\
16.5\end{array}$ & $\begin{array}{l}17.0 \\
16.5 \\
12.0 \\
14.0 \\
16.0\end{array}$ & $\begin{array}{l}15.0 \\
12.0 \\
11.0 \\
11.5 \\
13.5\end{array}$ & $\begin{array}{l}16.0 \\
13.5 \\
11.5 \\
12.5 \\
15.0\end{array}$ & $\begin{array}{r}8.0 \\
7.0 \\
2.5 \\
.5 \\
1.5\end{array}$ & $\begin{array}{r}5.5 \\
2.5 \\
.0 \\
.0 \\
.0\end{array}$ & $\begin{array}{r}6.5 \\
4.5 \\
1.0 \\
.0 \\
.0\end{array}$ & $\begin{array}{l}2.5 \\
1.5 \\
1.0 \\
3.5 \\
7.0\end{array}$ & $\begin{array}{r}.0 \\
.0 \\
.0 \\
.0 \\
2.5\end{array}$ & $\begin{array}{r}.5 \\
.0 \\
.0 \\
1.5 \\
4.5\end{array}$ \\
\hline $\begin{array}{l}18.5 \\
15.5 \\
15.0 \\
16.5 \\
19.0\end{array}$ & $\begin{array}{l}15.5 \\
13.5 \\
12.5 \\
13.0 \\
15.5\end{array}$ & $\begin{array}{l}17.0 \\
14.0 \\
13.5 \\
14.5 \\
17.0\end{array}$ & $\begin{array}{r}15.0 \\
13.0 \\
14.5 \\
13.5 \\
6.5\end{array}$ & $\begin{array}{r}13.0 \\
12.0 \\
12.5 \\
6.5 \\
6.0\end{array}$ & $\begin{array}{r}14.0 \\
12.5 \\
13.5 \\
8.5 \\
6.0\end{array}$ & $\begin{array}{c}6.0 \\
-- \\
--- \\
-- \\
---\end{array}$ & $\begin{array}{l}.0 \\
--- \\
--- \\
--- \\
---\end{array}$ & $\begin{array}{c}3.0 \\
--- \\
--- \\
--- \\
---\end{array}$ & $\begin{array}{r}12.5 \\
11.5 \\
11.0 \\
12.5 \\
9.0\end{array}$ & $\begin{array}{l}7.0 \\
9.0 \\
9.0 \\
9.0 \\
6.5\end{array}$ & $\begin{array}{r}10.0 \\
10.5 \\
10.0 \\
10.5 \\
8.0\end{array}$ \\
\hline $\begin{array}{l}21.5 \\
22.0 \\
18.5 \\
19.5 \\
18.0 \\
17.0\end{array}$ & $\begin{array}{l}18.5 \\
18.5 \\
17.0 \\
17.0 \\
14.5 \\
13.5\end{array}$ & $\begin{array}{l}19.5 \\
20.5 \\
17.5 \\
18.0 \\
16.5 \\
15.0\end{array}$ & $\begin{array}{r}6.5 \\
7.0 \\
7.0 \\
7.0 \\
8.5 \\
---\end{array}$ & $\begin{array}{r}5.5 \\
6.0 \\
6.0 \\
6.5 \\
7.0 \\
---\end{array}$ & $\begin{array}{r}6.0 \\
6.5 \\
6.5 \\
7.0 \\
7.5 \\
---\end{array}$ & $\begin{array}{l}--- \\
--- \\
--- \\
--- \\
-- \\
11.5\end{array}$ & $\begin{array}{l}--- \\
--- \\
--- \\
--- \\
-- \\
10.0\end{array}$ & $\begin{array}{l}--- \\
--- \\
--- \\
--- \\
--- \\
11.0\end{array}$ & $\begin{array}{r}11.5 \\
11.5 \\
4.0 \\
4.0 \\
5.5 \\
8.5\end{array}$ & $\begin{array}{r}6.5 \\
4.0 \\
.0 \\
.0 \\
.0 \\
2.5\end{array}$ & $\begin{array}{l}9.0 \\
9.0 \\
2.0 \\
2.0 \\
3.0 \\
5.0\end{array}$ \\
\hline 25.0 & 12.0 & 18.3 & 19.5 & 5.5 & 11.4 & -- & -- & -- & 17.0 & .0 & 5.6 \\
\hline
\end{tabular}

MONTH

$12.0 \quad 18.3$

$19.5 \quad 5.5$

11.4 
07330500 CADDO CREEK NEAR ARDMORE, OK--Continued

WATER TEMPERATURE, DEGREES CELSIUS, WATER YEAR OCTOBER 1996 TO SEPTEMBER 1997

\begin{tabular}{|c|c|c|c|c|c|c|c|c|c|c|c|c|}
\hline \multirow[t]{2}{*}{ DAY } & MAX & MIN & MEAN & MAX & MIN & MEAN & MAX & MIN & MEAN & MAX & MIN & MEAN \\
\hline & \multicolumn{3}{|c|}{ FEBRUARY } & \multicolumn{3}{|c|}{ MARCH } & \multicolumn{3}{|c|}{ APRIL } & \multicolumn{3}{|c|}{ MAY } \\
\hline $\begin{array}{l}1 \\
2 \\
3 \\
4 \\
5\end{array}$ & $\begin{array}{r}10.5 \\
12.5 \\
13.0 \\
12.5 \\
9.5\end{array}$ & $\begin{array}{l}5.5 \\
7.5 \\
9.0 \\
8.0 \\
7.0\end{array}$ & $\begin{array}{r}7.5 \\
9.5 \\
10.5 \\
10.0 \\
8.0\end{array}$ & $\begin{array}{l}13.5 \\
12.5 \\
13.0 \\
16.0 \\
14.5\end{array}$ & $\begin{array}{r}10.5 \\
10.0 \\
8.0 \\
11.0 \\
12.0\end{array}$ & $\begin{array}{l}12.0 \\
11.0 \\
10.0 \\
13.0 \\
13.5\end{array}$ & $\begin{array}{l}17.0 \\
17.5 \\
18.5 \\
18.5 \\
19.0\end{array}$ & $\begin{array}{l}15.5 \\
15.5 \\
16.5 \\
17.0 \\
16.5\end{array}$ & $\begin{array}{l}16.5 \\
16.5 \\
17.5 \\
17.5 \\
17.5\end{array}$ & $\begin{array}{l}22.0 \\
--- \\
--- \\
--- \\
---\end{array}$ & $\begin{array}{l}17.5 \\
--- \\
--- \\
--- \\
---\end{array}$ & $\begin{array}{l}20.0 \\
--- \\
--- \\
--- \\
---\end{array}$ \\
\hline $\begin{array}{r}6 \\
7 \\
8 \\
9 \\
10\end{array}$ & $\begin{array}{l}8.0 \\
7.0 \\
6.0 \\
5.0 \\
6.0\end{array}$ & $\begin{array}{l}7.0 \\
5.5 \\
5.0 \\
4.0 \\
3.5\end{array}$ & $\begin{array}{l}7.5 \\
6.0 \\
5.5 \\
4.5 \\
5.0\end{array}$ & $\begin{array}{l}14.0 \\
12.5 \\
12.5 \\
15.5 \\
17.0\end{array}$ & $\begin{array}{r}9.5 \\
10.5 \\
10.5 \\
12.5 \\
12.5\end{array}$ & $\begin{array}{l}12.0 \\
11.0 \\
11.5 \\
14.0 \\
14.5\end{array}$ & $\begin{array}{l}18.5 \\
18.0 \\
17.5 \\
14.5 \\
18.0\end{array}$ & $\begin{array}{l}15.5 \\
14.0 \\
14.5 \\
12.0 \\
13.0\end{array}$ & $\begin{array}{l}17.0 \\
16.0 \\
16.0 \\
13.5 \\
15.5\end{array}$ & $\begin{array}{l}--- \\
--- \\
--- \\
--- \\
---\end{array}$ & $\begin{array}{l}--- \\
--- \\
--- \\
--- \\
--\end{array}$ & $\begin{array}{l}--- \\
--- \\
--- \\
--- \\
---\end{array}$ \\
\hline $\begin{array}{l}11 \\
12 \\
13 \\
14 \\
15\end{array}$ & $\begin{array}{l}8.5 \\
8.5 \\
6.0 \\
8.5 \\
9.0\end{array}$ & $\begin{array}{l}3.0 \\
6.0 \\
5.0 \\
5.0 \\
4.5\end{array}$ & $\begin{array}{l}5.0 \\
7.0 \\
5.5 \\
6.5 \\
7.5\end{array}$ & $\begin{array}{l}18.5 \\
17.5 \\
16.5 \\
16.0 \\
12.5\end{array}$ & $\begin{array}{r}13.0 \\
15.0 \\
15.0 \\
12.0 \\
8.5\end{array}$ & $\begin{array}{l}15.5 \\
16.0 \\
16.0 \\
13.5 \\
11.0\end{array}$ & $\begin{array}{l}18.0 \\
12.5 \\
14.0 \\
16.0 \\
18.0\end{array}$ & $\begin{array}{l}12.0 \\
11.0 \\
11.0 \\
11.0 \\
13.0\end{array}$ & $\begin{array}{l}14.5 \\
11.5 \\
12.0 \\
13.5 \\
15.5\end{array}$ & $\begin{array}{l}--- \\
--- \\
--- \\
--- \\
---\end{array}$ & $\begin{array}{l}--- \\
--- \\
--- \\
--- \\
---\end{array}$ & $\begin{array}{l}--- \\
--- \\
--- \\
--- \\
---\end{array}$ \\
\hline $\begin{array}{l}16 \\
17 \\
18 \\
19 \\
20\end{array}$ & $\begin{array}{l}10.5 \\
11.5 \\
13.0 \\
14.0 \\
13.5\end{array}$ & $\begin{array}{r}6.0 \\
7.0 \\
9.5 \\
12.5 \\
12.5\end{array}$ & $\begin{array}{r}8.5 \\
10.0 \\
11.5 \\
13.0 \\
12.5\end{array}$ & $\begin{array}{l}11.5 \\
14.0 \\
15.0 \\
14.0 \\
16.5\end{array}$ & $\begin{array}{r}9.5 \\
10.0 \\
13.0 \\
10.5 \\
11.0\end{array}$ & $\begin{array}{l}10.0 \\
11.5 \\
14.5 \\
12.0 \\
14.0\end{array}$ & $\begin{array}{l}19.5 \\
21.0 \\
19.5 \\
22.0 \\
23.5\end{array}$ & $\begin{array}{l}15.5 \\
17.0 \\
17.5 \\
16.5 \\
18.5\end{array}$ & $\begin{array}{l}17.5 \\
19.0 \\
18.5 \\
19.5 \\
21.5\end{array}$ & $\begin{array}{l}--- \\
--- \\
--- \\
--- \\
---\end{array}$ & $\begin{array}{l}--- \\
--- \\
--- \\
--- \\
---\end{array}$ & $\begin{array}{l}--- \\
--- \\
--- \\
--- \\
---\end{array}$ \\
\hline $\begin{array}{l}21 \\
22 \\
23 \\
24 \\
25\end{array}$ & $\begin{array}{l}14.0 \\
11.5 \\
11.0 \\
11.0 \\
11.0\end{array}$ & $\begin{array}{l}11.0 \\
10.0 \\
10.0 \\
11.0 \\
10.5\end{array}$ & $\begin{array}{l}12.5 \\
10.5 \\
11.0 \\
11.0 \\
10.5\end{array}$ & $\begin{array}{l}19.0 \\
19.0 \\
18.0 \\
20.5 \\
19.5\end{array}$ & $\begin{array}{l}13.5 \\
15.0 \\
13.5 \\
15.5 \\
16.5\end{array}$ & $\begin{array}{l}17.0 \\
17.0 \\
16.0 \\
18.0 \\
18.0\end{array}$ & $\begin{array}{l}23.5 \\
22.5 \\
21.5 \\
20.0 \\
15.5\end{array}$ & $\begin{array}{l}20.0 \\
19.5 \\
18.0 \\
15.5 \\
13.5\end{array}$ & $\begin{array}{l}22.0 \\
21.0 \\
19.5 \\
17.5 \\
14.5\end{array}$ & $\begin{array}{l}20.0 \\
23.0 \\
22.0 \\
-- \\
26.5\end{array}$ & $\begin{array}{l}19.0 \\
19.5 \\
20.5 \\
--- \\
23.0\end{array}$ & $\begin{array}{r}19.5 \\
21.0 \\
20.0 \\
-- \\
24.5\end{array}$ \\
\hline $\begin{array}{l}26 \\
27 \\
28 \\
29 \\
30 \\
31\end{array}$ & $\begin{array}{l}10.5 \\
10.5 \\
10.5 \\
--- \\
--- \\
---\end{array}$ & $\begin{array}{c}8.5 \\
8.5 \\
9.5 \\
--- \\
--- \\
---\end{array}$ & $\begin{array}{c}9.5 \\
9.0 \\
10.0 \\
-- \\
--- \\
--\end{array}$ & $\begin{array}{l}17.5 \\
19.0 \\
20.5 \\
20.5 \\
19.0 \\
19.0\end{array}$ & $\begin{array}{l}13.5 \\
14.5 \\
16.0 \\
15.0 \\
15.5 \\
13.5\end{array}$ & $\begin{array}{l}16.0 \\
17.0 \\
18.5 \\
18.0 \\
17.5 \\
16.5\end{array}$ & $\begin{array}{r}13.5 \\
15.0 \\
18.0 \\
21.0 \\
21.5 \\
--\end{array}$ & $\begin{array}{l}13.5 \\
13.5 \\
14.0 \\
16.0 \\
19.0 \\
---\end{array}$ & $\begin{array}{r}13.5 \\
14.0 \\
16.0 \\
18.5 \\
20.5 \\
-\end{array}$ & $\begin{array}{l}28.5 \\
28.0 \\
26.5 \\
26.0 \\
22.0 \\
23.0\end{array}$ & $\begin{array}{l}23.5 \\
25.0 \\
22.5 \\
22.0 \\
20.5 \\
21.0\end{array}$ & $\begin{array}{l}26.0 \\
26.5 \\
25.0 \\
24.0 \\
21.0 \\
22.0\end{array}$ \\
\hline T & 14.0 & 3.0 & 8.8 & 20.5 & 8.0 & 14.4 & 23.5 & 11.0 & 16.8 & - & -- & -- \\
\hline
\end{tabular}


07330500 CADDO CREEK NEAR ARDMORE, OK--Continued

WATER TEMPERATURE, DEGREES CELSIUS, WATER YEAR OCTOBER 1996 TO SEPTEMBER 1997

\begin{tabular}{|c|c|c|c|c|c|c|c|c|c|c|c|c|}
\hline \multirow[t]{2}{*}{ DAY } & MAX & MIN & MEAN & MAX & MIN & MEAN & MAX & MIN & MEAN & MAX & MIN & MEAN \\
\hline & \multicolumn{3}{|c|}{ JUNE } & \multicolumn{3}{|c|}{ JULY } & \multicolumn{3}{|c|}{ AUGUST } & \multicolumn{3}{|c|}{ SEPTEMBER } \\
\hline $\begin{array}{l}1 \\
2 \\
3 \\
4 \\
5\end{array}$ & $\begin{array}{l}24.5 \\
24.5 \\
24.5 \\
26.0 \\
26.0\end{array}$ & $\begin{array}{l}22.0 \\
23.0 \\
22.5 \\
22.5 \\
23.0\end{array}$ & $\begin{array}{l}23.0 \\
23.5 \\
23.5 \\
24.0 \\
24.5\end{array}$ & $\begin{array}{l}34.5 \\
36.0 \\
36.0 \\
31.0 \\
28.5\end{array}$ & $\begin{array}{l}27.5 \\
27.5 \\
28.5 \\
26.5 \\
23.5\end{array}$ & $\begin{array}{l}30.5 \\
31.0 \\
31.5 \\
29.0 \\
26.0\end{array}$ & $\begin{array}{l}34.5 \\
35.0 \\
35.5 \\
35.5 \\
36.0\end{array}$ & $\begin{array}{l}25.5 \\
25.5 \\
25.0 \\
25.5 \\
26.0\end{array}$ & $\begin{array}{l}29.5 \\
29.5 \\
29.5 \\
30.0 \\
30.5\end{array}$ & $\begin{array}{l}34.0 \\
34.0 \\
31.0 \\
28.5 \\
32.0\end{array}$ & $\begin{array}{l}25.0 \\
25.5 \\
26.5 \\
25.0 \\
22.5\end{array}$ & $\begin{array}{l}29.0 \\
29.5 \\
28.5 \\
26.5 \\
26.0\end{array}$ \\
\hline $\begin{array}{r}6 \\
7 \\
8 \\
9 \\
10\end{array}$ & $\begin{array}{l}26.0 \\
26.0 \\
25.0 \\
25.5 \\
22.5\end{array}$ & $\begin{array}{l}22.5 \\
22.5 \\
23.0 \\
20.5 \\
20.0\end{array}$ & $\begin{array}{l}24.5 \\
24.5 \\
23.5 \\
23.0 \\
21.5\end{array}$ & $\begin{array}{l}29.5 \\
28.0 \\
34.0 \\
34.5 \\
35.0\end{array}$ & $\begin{array}{l}24.0 \\
24.5 \\
25.0 \\
26.5 \\
27.0\end{array}$ & $\begin{array}{l}26.0 \\
26.0 \\
29.0 \\
30.0 \\
30.0\end{array}$ & $\begin{array}{l}30.0 \\
25.0 \\
24.0 \\
32.5 \\
33.0\end{array}$ & $\begin{array}{l}25.0 \\
21.5 \\
21.0 \\
20.5 \\
25.0\end{array}$ & $\begin{array}{l}27.0 \\
23.0 \\
22.5 \\
25.5 \\
28.0\end{array}$ & $\begin{array}{l}31.5 \\
32.5 \\
32.0 \\
29.0 \\
30.5\end{array}$ & $\begin{array}{l}22.0 \\
21.5 \\
23.5 \\
23.5 \\
21.0\end{array}$ & $\begin{array}{l}26.0 \\
26.5 \\
27.0 \\
26.0 \\
25.0\end{array}$ \\
\hline $\begin{array}{l}11 \\
12 \\
13 \\
14 \\
15\end{array}$ & $\begin{array}{l}24.5 \\
27.0 \\
28.0 \\
28.5 \\
27.5\end{array}$ & $\begin{array}{l}22.0 \\
23.5 \\
25.5 \\
25.0 \\
25.5\end{array}$ & $\begin{array}{l}23.0 \\
25.0 \\
27.0 \\
27.5 \\
26.5\end{array}$ & $\begin{array}{l}35.0 \\
35.0 \\
36.0 \\
37.0 \\
34.5\end{array}$ & $\begin{array}{l}27.0 \\
26.5 \\
27.0 \\
27.0 \\
27.5\end{array}$ & $\begin{array}{l}30.0 \\
30.0 \\
31.0 \\
31.5 \\
30.5\end{array}$ & $\begin{array}{l}30.5 \\
32.5 \\
33.0 \\
35.5 \\
34.5\end{array}$ & $\begin{array}{l}26.5 \\
25.5 \\
26.5 \\
26.5 \\
26.5\end{array}$ & $\begin{array}{l}28.0 \\
28.5 \\
29.5 \\
30.0 \\
30.0\end{array}$ & $\begin{array}{l}30.0 \\
29.5 \\
31.5 \\
32.5 \\
31.0\end{array}$ & $\begin{array}{l}18.5 \\
19.5 \\
23.5 \\
24.5 \\
24.5\end{array}$ & $\begin{array}{l}23.5 \\
24.0 \\
26.5 \\
27.5 \\
27.0\end{array}$ \\
\hline $\begin{array}{l}16 \\
17 \\
18 \\
19 \\
20\end{array}$ & $\begin{array}{l}30.0 \\
48.0 \\
29.0 \\
30.5 \\
32.0\end{array}$ & $\begin{array}{l}25.5 \\
25.0 \\
24.0 \\
25.5 \\
27.0\end{array}$ & $\begin{array}{l}27.5 \\
27.5 \\
27.0 \\
28.5 \\
29.5\end{array}$ & $\begin{array}{l}35.5 \\
35.0 \\
31.0 \\
34.5 \\
35.0\end{array}$ & $\begin{array}{l}25.5 \\
27.5 \\
27.0 \\
26.5 \\
26.5\end{array}$ & $\begin{array}{l}30.0 \\
30.5 \\
29.0 \\
30.0 \\
30.5\end{array}$ & $\begin{array}{l}35.0 \\
33.5 \\
34.5 \\
30.5 \\
34.5\end{array}$ & $\begin{array}{l}26.0 \\
26.5 \\
26.5 \\
26.5 \\
25.5\end{array}$ & $\begin{array}{l}29.5 \\
29.0 \\
29.0 \\
28.0 \\
29.5\end{array}$ & $\begin{array}{l}33.0 \\
32.5 \\
33.0 \\
32.5 \\
30.5\end{array}$ & $\begin{array}{l}24.5 \\
25.0 \\
25.0 \\
24.5 \\
24.5\end{array}$ & $\begin{array}{l}27.5 \\
28.0 \\
28.0 \\
28.0 \\
27.0\end{array}$ \\
\hline $\begin{array}{l}21 \\
22 \\
23 \\
24 \\
25\end{array}$ & $\begin{array}{r}31.5 \\
29.5 \\
26.5 \\
-- \\
31.0\end{array}$ & $\begin{array}{l}27.0 \\
26.5 \\
25.0 \\
-- \\
25.5\end{array}$ & $\begin{array}{r}29.0 \\
27.5 \\
26.0 \\
-- \\
28.0\end{array}$ & $\begin{array}{l}36.5 \\
35.5 \\
35.0 \\
37.0 \\
35.5\end{array}$ & $\begin{array}{l}27.0 \\
27.0 \\
27.0 \\
27.5 \\
28.0\end{array}$ & $\begin{array}{l}31.0 \\
30.5 \\
30.5 \\
31.5 \\
31.5\end{array}$ & $\begin{array}{l}35.0 \\
32.5 \\
32.5 \\
33.0 \\
33.5\end{array}$ & $\begin{array}{l}25.5 \\
24.0 \\
25.0 \\
23.5 \\
23.0\end{array}$ & $\begin{array}{l}29.5 \\
28.0 \\
28.0 \\
27.5 \\
27.5\end{array}$ & $\begin{array}{l}27.5 \\
26.0 \\
25.5 \\
23.0 \\
22.0\end{array}$ & $\begin{array}{l}21.0 \\
22.5 \\
22.5 \\
21.0 \\
19.5\end{array}$ & $\begin{array}{l}23.5 \\
24.0 \\
24.0 \\
21.5 \\
20.5\end{array}$ \\
\hline $\begin{array}{l}26 \\
27 \\
28 \\
29 \\
30 \\
31\end{array}$ & $\begin{array}{l}32.0 \\
33.0 \\
32.0 \\
33.5 \\
33.5 \\
---\end{array}$ & $\begin{array}{r}26.5 \\
27.0 \\
28.5 \\
27.0 \\
27.0 \\
--\end{array}$ & $\begin{array}{r}29.0 \\
29.5 \\
30.0 \\
29.5 \\
30.0 \\
---\end{array}$ & $\begin{array}{l}36.5 \\
37.0 \\
37.0 \\
35.5 \\
32.0 \\
34.0\end{array}$ & $\begin{array}{l}27.5 \\
27.5 \\
27.5 \\
28.0 \\
26.5 \\
24.5\end{array}$ & $\begin{array}{l}31.5 \\
31.5 \\
31.5 \\
30.5 \\
29.0 \\
29.0\end{array}$ & $\begin{array}{l}34.0 \\
34.0 \\
34.0 \\
34.5 \\
35.0 \\
34.5\end{array}$ & $\begin{array}{l}23.0 \\
23.0 \\
23.5 \\
24.5 \\
24.5 \\
25.0\end{array}$ & $\begin{array}{l}27.5 \\
27.5 \\
28.0 \\
28.5 \\
29.0 \\
29.0\end{array}$ & $\begin{array}{l}27.0 \\
28.5 \\
28.0 \\
29.0 \\
30.0 \\
---\end{array}$ & $\begin{array}{l}16.0 \\
18.0 \\
19.5 \\
18.5 \\
20.5 \\
--\end{array}$ & $\begin{array}{l}21.0 \\
22.5 \\
23.0 \\
22.5 \\
24.5 \\
---\end{array}$ \\
\hline$\Gamma \mathrm{TH}$ & --- & -- & --- & 37.0 & 23.5 & 30.0 & 36.0 & 20.5 & 28.3 & 34.0 & 16.0 & 25.5 \\
\hline
\end{tabular}


07330500 CADDO CREEK NEAR ARDMORE, OK-Continued

OXYGEN DISSOLVED (MG/L), WATER YEAR OCTOBER 1996 TO SEPTEMBER 1997

\begin{tabular}{|c|c|c|c|c|c|c|c|c|c|c|c|c|}
\hline \multirow[t]{2}{*}{ DAY } & MAX & MIN & MEAN & MAX & MIN & MEAN & MAX & MIN & MEAN & MAX & MIN & MEAN \\
\hline & \multicolumn{3}{|c|}{ OCTOBER } & \multicolumn{3}{|c|}{ NOVEMBER } & \multicolumn{3}{|c|}{ DECEMBER } & \multicolumn{3}{|c|}{ JANUARY } \\
\hline $\begin{array}{l}1 \\
2 \\
3 \\
4 \\
5\end{array}$ & $\begin{array}{l}8.9 \\
8.3 \\
8.1 \\
8.2 \\
8.2\end{array}$ & $\begin{array}{l}7.7 \\
7.6 \\
7.6 \\
7.7 \\
7.7\end{array}$ & $\begin{array}{l}8.4 \\
8.0 \\
7.9 \\
8.0 \\
7.9\end{array}$ & $\begin{array}{r}10.2 \\
10.5 \\
10.3 \\
10.0 \\
9.7\end{array}$ & $\begin{array}{l}9.4 \\
9.5 \\
9.3 \\
9.0 \\
8.5\end{array}$ & $\begin{array}{r}9.9 \\
10.1 \\
9.9 \\
9.4 \\
9.2\end{array}$ & $\begin{array}{l}11.4 \\
11.5 \\
11.5 \\
11.8 \\
11.4\end{array}$ & $\begin{array}{l}11.0 \\
11.2 \\
11.2 \\
11.3 \\
11.0\end{array}$ & $\begin{array}{l}11.2 \\
11.3 \\
11.4 \\
11.5 \\
11.2\end{array}$ & $\begin{array}{l}11.3 \\
11.3 \\
10.6 \\
10.3 \\
11.0\end{array}$ & $\begin{array}{r}10.2 \\
9.3 \\
8.9 \\
8.7 \\
9.5\end{array}$ & $\begin{array}{r}10.6 \\
10.4 \\
9.6 \\
9.4 \\
10.2\end{array}$ \\
\hline $\begin{array}{r}6 \\
7 \\
8 \\
9 \\
10\end{array}$ & $\begin{array}{l}8.1 \\
8.1 \\
8.1 \\
8.6 \\
8.8\end{array}$ & $\begin{array}{l}7.5 \\
7.4 \\
7.4 \\
7.7 \\
8.0\end{array}$ & $\begin{array}{l}7.8 \\
7.7 \\
7.7 \\
8.2 \\
8.5\end{array}$ & $\begin{array}{r}8.9 \\
8.9 \\
9.7 \\
10.3 \\
10.3\end{array}$ & $\begin{array}{l}8.3 \\
8.4 \\
8.8 \\
9.7 \\
9.7\end{array}$ & $\begin{array}{r}8.5 \\
8.7 \\
9.4 \\
10.0 \\
10.0\end{array}$ & $\begin{array}{l}11.0 \\
11.1 \\
11.6 \\
11.4 \\
10.9\end{array}$ & $\begin{array}{l}10.7 \\
10.8 \\
10.9 \\
10.7 \\
10.0\end{array}$ & $\begin{array}{l}10.9 \\
10.9 \\
11.3 \\
11.1 \\
10.6\end{array}$ & $\begin{array}{l}11.7 \\
12.4 \\
12.2 \\
12.3 \\
12.6\end{array}$ & $\begin{array}{l}10.4 \\
11.4 \\
11.7 \\
11.8 \\
11.7\end{array}$ & $\begin{array}{l}11.1 \\
11.9 \\
12.0 \\
12.1 \\
12.2\end{array}$ \\
\hline $\begin{array}{l}11 \\
12 \\
13 \\
14 \\
15\end{array}$ & $\begin{array}{l}8.9 \\
8.7 \\
8.5 \\
8.6 \\
8.5\end{array}$ & $\begin{array}{l}8.4 \\
8.2 \\
8.2 \\
8.2 \\
8.0\end{array}$ & $\begin{array}{l}8.6 \\
8.4 \\
8.3 \\
8.4 \\
8.3\end{array}$ & $\begin{array}{r}10.4 \\
10.3 \\
10.5 \\
10.0 \\
9.6\end{array}$ & $\begin{array}{l}9.7 \\
9.7 \\
9.9 \\
9.1 \\
9.1\end{array}$ & $\begin{array}{r}10.1 \\
10.1 \\
10.3 \\
9.7 \\
9.3\end{array}$ & $\begin{array}{l}10.5 \\
10.9 \\
11.2 \\
--- \\
---\end{array}$ & $\begin{array}{l}10.0 \\
10.1 \\
10.4 \\
--- \\
---\end{array}$ & $\begin{array}{l}10.3 \\
10.6 \\
10.9 \\
--- \\
---\end{array}$ & $\begin{array}{l}13.4 \\
13.8 \\
13.9 \\
13.7 \\
13.3\end{array}$ & $\begin{array}{l}12.4 \\
13.3 \\
13.5 \\
13.3 \\
12.8\end{array}$ & $\begin{array}{l}13.0 \\
13.5 \\
13.6 \\
13.5 \\
13.1\end{array}$ \\
\hline $\begin{array}{l}16 \\
17 \\
18 \\
19 \\
20\end{array}$ & $\begin{array}{l}8.3 \\
8.5 \\
9.3 \\
9.8 \\
9.3\end{array}$ & $\begin{array}{l}7.7 \\
7.8 \\
8.5 \\
9.1 \\
8.4\end{array}$ & $\begin{array}{l}8.1 \\
8.1 \\
9.0 \\
9.4 \\
9.0\end{array}$ & $\begin{array}{r}9.2 \\
9.6 \\
10.1 \\
10.1 \\
9.6\end{array}$ & $\begin{array}{l}8.6 \\
7.3 \\
9.6 \\
9.6 \\
9.2\end{array}$ & $\begin{array}{l}9.1 \\
8.5 \\
9.9 \\
9.9 \\
9.4\end{array}$ & $\begin{array}{l}12.4 \\
12.8 \\
13.5 \\
13.9 \\
13.7\end{array}$ & $\begin{array}{l}11.4 \\
11.8 \\
12.8 \\
13.3 \\
13.1\end{array}$ & $\begin{array}{l}12.1 \\
12.4 \\
13.3 \\
13.7 \\
13.4\end{array}$ & $\begin{array}{l}13.5 \\
13.9 \\
13.9 \\
13.6 \\
12.6\end{array}$ & $\begin{array}{l}12.9 \\
13.4 \\
13.3 \\
12.2 \\
11.3\end{array}$ & $\begin{array}{l}13.4 \\
13.5 \\
13.6 \\
13.1 \\
12.1\end{array}$ \\
\hline $\begin{array}{l}21 \\
22 \\
23 \\
24 \\
25\end{array}$ & $\begin{array}{r}8.4 \\
9.5 \\
10.1 \\
10.1 \\
9.7\end{array}$ & $\begin{array}{l}7.7 \\
8.4 \\
9.5 \\
9.6 \\
9.1\end{array}$ & $\begin{array}{l}8.0 \\
9.2 \\
9.8 \\
9.8 \\
9.5\end{array}$ & $\begin{array}{r}9.8 \\
10.3 \\
10.1 \\
11.2 \\
11.8\end{array}$ & $\begin{array}{r}9.3 \\
9.8 \\
9.8 \\
9.8 \\
11.2\end{array}$ & $\begin{array}{r}9.6 \\
10.1 \\
10.0 \\
10.6 \\
11.5\end{array}$ & $\begin{array}{l}13.1 \\
--- \\
--- \\
--- \\
---\end{array}$ & $\begin{array}{l}11.9 \\
--- \\
--- \\
--- \\
---\end{array}$ & $\begin{array}{l}12.7 \\
--- \\
--- \\
--- \\
---\end{array}$ & $\begin{array}{l}11.3 \\
11.3 \\
11.5 \\
10.8 \\
11.5\end{array}$ & $\begin{array}{r}10.1 \\
10.0 \\
10.1 \\
9.8 \\
10.2\end{array}$ & $\begin{array}{l}10.8 \\
10.6 \\
10.7 \\
10.4 \\
10.9\end{array}$ \\
\hline $\begin{array}{l}26 \\
27 \\
28 \\
29 \\
30 \\
31\end{array}$ & $\begin{array}{r}9.2 \\
9.2 \\
9.8 \\
9.6 \\
10.2 \\
9.8\end{array}$ & $\begin{array}{l}8.7 \\
8.8 \\
9.2 \\
9.3 \\
9.3 \\
9.2\end{array}$ & $\begin{array}{l}9.1 \\
9.0 \\
9.6 \\
9.5 \\
9.7 \\
9.5\end{array}$ & $\begin{array}{l}11.9 \\
11.7 \\
11.7 \\
11.5 \\
11.1 \\
---\end{array}$ & $\begin{array}{l}11.7 \\
11.3 \\
11.5 \\
11.1 \\
11.0 \\
---\end{array}$ & $\begin{array}{l}11.8 \\
11.6 \\
11.6 \\
11.3 \\
11.0 \\
--\end{array}$ & $\begin{array}{l}\cdots \\
--- \\
--- \\
--- \\
--- \\
11.2\end{array}$ & $\begin{array}{l}--. \\
--- \\
--- \\
--- \\
--- \\
10.4\end{array}$ & $\begin{array}{l}-- \\
--- \\
--- \\
--- \\
--- \\
10.8\end{array}$ & $\begin{array}{l}11.3 \\
11.5 \\
13.2 \\
13.2 \\
13.0 \\
12.1\end{array}$ & $\begin{array}{r}10.1 \\
9.6 \\
11.5 \\
12.8 \\
12.1 \\
11.1\end{array}$ & $\begin{array}{l}10.9 \\
10.6 \\
12.6 \\
12.9 \\
12.7 \\
11.7\end{array}$ \\
\hline TTH & 10.2 & 7.4 & 8.7 & 11.9 & 7.3 & 10.0 & -- & $\cdots$ & --- & 13.9 & 8.7 & 11.8 \\
\hline
\end{tabular}


07330500 CADDO CREEK NEAR ARDMORE, OK--Continued

OXYGEN DISSOLVED (MG/L), WATER YEAR OCTOBER 1996 TO SEPTEMBER 1997

\begin{tabular}{|c|c|c|c|c|c|c|c|c|c|c|c|c|}
\hline \multirow[t]{2}{*}{ DAY } & MAX & MIN & MEAN & MAX & MIN & MEAN & MAX & MIN & MEAN & MAX & MIN & MEAN \\
\hline & \multicolumn{3}{|c|}{ FEBRUARY } & \multicolumn{3}{|c|}{ MARCH } & \multicolumn{3}{|c|}{ APRIL } & \multicolumn{3}{|c|}{ MAY } \\
\hline $\begin{array}{l}1 \\
2 \\
3 \\
4 \\
5\end{array}$ & $\begin{array}{l}11.2 \\
11.0 \\
10.6 \\
10.8 \\
11.2\end{array}$ & $\begin{array}{r}10.5 \\
10.1 \\
9.8 \\
9.7 \\
10.2\end{array}$ & $\begin{array}{l}10.9 \\
10.5 \\
10.1 \\
10.2 \\
10.7\end{array}$ & $\begin{array}{l}10.3 \\
10.5 \\
11.0 \\
10.4 \\
10.3\end{array}$ & $\begin{array}{r}9.9 \\
9.9 \\
10.2 \\
9.6 \\
9.7\end{array}$ & $\begin{array}{l}10.1 \\
10.3 \\
10.6 \\
10.1 \\
10.0\end{array}$ & $\begin{array}{l}7.8 \\
7.6 \\
7.4 \\
6.5 \\
6.1\end{array}$ & $\begin{array}{l}6.8 \\
6.7 \\
6.4 \\
5.9 \\
5.8\end{array}$ & $\begin{array}{l}7.2 \\
7.1 \\
6.9 \\
6.2 \\
6.0\end{array}$ & $\begin{array}{l}10.4 \\
--- \\
--- \\
--- \\
---\end{array}$ & $\begin{array}{c}8.4 \\
--- \\
--- \\
--- \\
---\end{array}$ & $\begin{array}{c}9.0 \\
-- \\
-- \\
-- \\
--\end{array}$ \\
\hline $\begin{array}{r}6 \\
7 \\
8 \\
9 \\
10\end{array}$ & $\begin{array}{l}10.9 \\
10.8 \\
11.0 \\
11.3 \\
11.5\end{array}$ & $\begin{array}{l}10.2 \\
10.3 \\
10.6 \\
11.0 \\
10.9\end{array}$ & $\begin{array}{l}10.5 \\
10.5 \\
10.8 \\
11.2 \\
11.3\end{array}$ & $\begin{array}{l}10.9 \\
10.6 \\
10.4 \\
10.1 \\
10.1\end{array}$ & $\begin{array}{r}10.1 \\
10.2 \\
10.1 \\
9.5 \\
9.3\end{array}$ & $\begin{array}{r}10.5 \\
10.4 \\
10.3 \\
9.8 \\
9.7\end{array}$ & $\begin{array}{l}7.0 \\
7.4 \\
7.2 \\
7.8 \\
7.7\end{array}$ & $\begin{array}{l}6.0 \\
6.6 \\
6.6 \\
6.9 \\
6.4\end{array}$ & $\begin{array}{l}6.7 \\
7.0 \\
7.0 \\
7.4 \\
7.2\end{array}$ & $\begin{array}{l}--- \\
--- \\
--- \\
--- \\
---\end{array}$ & $\begin{array}{l}--- \\
--- \\
--- \\
---\end{array}$ & $\begin{array}{l}-- \\
-- \\
--- \\
--- \\
---\end{array}$ \\
\hline $\begin{array}{l}11 \\
12 \\
13 \\
14 \\
15\end{array}$ & $\begin{array}{l}11.8 \\
10.8 \\
11.5 \\
11.6 \\
11.7\end{array}$ & $\begin{array}{l}10.4 \\
10.4 \\
10.8 \\
10.5 \\
10.4\end{array}$ & $\begin{array}{l}11.3 \\
10.6 \\
11.1 \\
11.2 \\
11.1\end{array}$ & $\begin{array}{r}9.9 \\
9.7 \\
9.7 \\
10.4 \\
11.0\end{array}$ & $\begin{array}{l}9.0 \\
9.0 \\
9.1 \\
9.1 \\
9.9\end{array}$ & $\begin{array}{r}9.5 \\
9.4 \\
9.4 \\
9.8 \\
10.5\end{array}$ & $\begin{array}{r}9.2 \\
10.1 \\
10.3 \\
10.2 \\
10.1\end{array}$ & $\begin{array}{l}6.3 \\
9.2 \\
9.8 \\
9.6 \\
9.2\end{array}$ & $\begin{array}{r}7.0 \\
9.7 \\
10.0 \\
9.9 \\
9.7\end{array}$ & $\begin{array}{l}--- \\
--- \\
--- \\
--- \\
---\end{array}$ & $\begin{array}{l}--- \\
--- \\
--- \\
--- \\
---\end{array}$ & $\begin{array}{l}--- \\
--- \\
--- \\
--- \\
---\end{array}$ \\
\hline $\begin{array}{l}16 \\
17 \\
18 \\
19 \\
20\end{array}$ & $\begin{array}{r}11.7 \\
11.3 \\
10.8 \\
10.2 \\
9.5\end{array}$ & $\begin{array}{r}10.2 \\
9.9 \\
9.5 \\
9.2 \\
8.7\end{array}$ & $\begin{array}{r}10.9 \\
10.6 \\
10.2 \\
9.6 \\
9.1\end{array}$ & $\begin{array}{l}10.8 \\
10.6 \\
10.0 \\
10.8 \\
10.2\end{array}$ & $\begin{array}{r}10.0 \\
9.5 \\
9.3 \\
9.2 \\
8.4\end{array}$ & $\begin{array}{r}10.5 \\
10.2 \\
9.6 \\
10.0 \\
9.5\end{array}$ & $\begin{array}{l}9.7 \\
9.7 \\
9.4 \\
9.2 \\
8.9\end{array}$ & $\begin{array}{l}9.1 \\
8.8 \\
8.6 \\
8.0 \\
7.7\end{array}$ & $\begin{array}{l}9.4 \\
9.3 \\
9.1 \\
8.7 \\
8.4\end{array}$ & $\begin{array}{l}--- \\
--- \\
--- \\
--- \\
---\end{array}$ & $\begin{array}{l}--- \\
--- \\
--- \\
--- \\
---\end{array}$ & $\begin{array}{l}--- \\
--- \\
--- \\
---\end{array}$ \\
\hline $\begin{array}{l}21 \\
22 \\
23 \\
24 \\
25\end{array}$ & $\begin{array}{l}10.1 \\
10.5 \\
10.6 \\
10.5 \\
10.4\end{array}$ & $\begin{array}{r}9.0 \\
10.1 \\
10.1 \\
10.1 \\
10.3\end{array}$ & $\begin{array}{r}9.5 \\
10.4 \\
10.3 \\
10.3 \\
10.3\end{array}$ & $\begin{array}{l}9.6 \\
9.6 \\
9.9 \\
9.6 \\
9.5\end{array}$ & $\begin{array}{l}7.9 \\
7.9 \\
8.3 \\
7.8 \\
7.8\end{array}$ & $\begin{array}{l}8.9 \\
8.7 \\
9.1 \\
8.8 \\
8.6\end{array}$ & $\begin{array}{r}--- \\
--- \\
-- \\
9.5 \\
9.8\end{array}$ & $\begin{array}{r}--- \\
--- \\
--- \\
8.4 \\
9.3\end{array}$ & $\begin{array}{r}--- \\
--- \\
--- \\
9.0 \\
9.5\end{array}$ & $\begin{array}{c}8.3 \\
8.4 \\
--- \\
--- \\
---\end{array}$ & $\begin{array}{c}8.0 \\
7.9 \\
--- \\
--- \\
---\end{array}$ & $\begin{array}{r}8.2 \\
8.1 \\
--- \\
--- \\
---\end{array}$ \\
\hline $\begin{array}{l}26 \\
27 \\
28 \\
29 \\
30 \\
31\end{array}$ & $\begin{array}{l}10.5 \\
10.7 \\
10.4 \\
--- \\
--- \\
---\end{array}$ & $\begin{array}{l}10.2 \\
10.3 \\
10.3 \\
-- \\
-- \\
--\end{array}$ & $\begin{array}{l}10.3 \\
10.6 \\
10.4 \\
-- \\
-\cdots \\
-\cdots\end{array}$ & $\begin{array}{l}9.7 \\
9.9 \\
9.1 \\
8.5 \\
8.3 \\
8.2\end{array}$ & $\begin{array}{l}8.2 \\
7.7 \\
7.3 \\
6.8 \\
6.8 \\
6.9\end{array}$ & $\begin{array}{l}9.0 \\
8.8 \\
8.1 \\
7.7 \\
7.5 \\
7.6\end{array}$ & $\begin{array}{r}9.5 \\
9.9 \\
10.0 \\
9.7 \\
9.7 \\
--\end{array}$ & $\begin{array}{r}8.9 \\
9.4 \\
8.9 \\
8.4 \\
8.4 \\
---\end{array}$ & $\begin{array}{r}9.3 \\
9.6 \\
9.4 \\
8.9 \\
8.7 \\
---\end{array}$ & $\begin{array}{l}--- \\
--- \\
--- \\
--- \\
--- \\
---\end{array}$ & $\begin{array}{l}--- \\
--- \\
--- \\
--- \\
---\end{array}$ & $\begin{array}{l}--- \\
--- \\
--- \\
--- \\
--- \\
---\end{array}$ \\
\hline $\mathrm{NTH}$ & 11.8 & 8.7 & 10.5 & 11.0 & 6.8 & 9.5 & -.- & $\ldots$ & $\ldots$ & --- & -. & -- \\
\hline
\end{tabular}


07330500 CADDO CREEK NEAR ARDMORE, OK--Continued

OXYGEN DISSOLVED (MG/L), WATER YEAR OCTOBER 1996 TO SEPTEMBER 1997

\begin{tabular}{|c|c|c|c|c|c|c|c|c|c|c|c|c|}
\hline \multirow[t]{2}{*}{ DAY } & MAX & MIN & MEAN & MAX & MIN & MEAN & MAX & IN & MEAN & MAX & MIN & MEAN \\
\hline & \multicolumn{3}{|c|}{ JUNE } & \multicolumn{3}{|c|}{ JULY } & \multicolumn{3}{|c|}{ AUGUST } & \multicolumn{3}{|c|}{ SEPTEMBER } \\
\hline $\begin{array}{l}1 \\
2 \\
3 \\
4 \\
5\end{array}$ & $\begin{array}{l}--- \\
--- \\
--- \\
--- \\
---\end{array}$ & $\begin{array}{l}--- \\
--- \\
--- \\
--- \\
---\end{array}$ & $\begin{array}{l}--- \\
--- \\
--- \\
--- \\
---\end{array}$ & $\begin{array}{l}7.3 \\
7.4 \\
7.3 \\
7.9 \\
8.0\end{array}$ & $\begin{array}{l}6.6 \\
6.6 \\
6.5 \\
6.5 \\
7.1\end{array}$ & $\begin{array}{l}6.9 \\
6.9 \\
6.8 \\
7.2 \\
7.5\end{array}$ & $\begin{array}{l}8.6 \\
8.6 \\
8.5 \\
8.4 \\
8.3\end{array}$ & $\begin{array}{l}6.4 \\
6.1 \\
6.0 \\
5.7 \\
5.6\end{array}$ & $\begin{array}{l}7.2 \\
7.1 \\
7.0 \\
6.8 \\
6.7\end{array}$ & $\begin{array}{l}9.7 \\
9.9 \\
9.7 \\
8.8 \\
9.5\end{array}$ & $\begin{array}{l}5.7 \\
5.6 \\
5.6 \\
6.0 \\
6.5\end{array}$ & $\begin{array}{l}7.3 \\
7.3 \\
6.8 \\
7.1 \\
7.7\end{array}$ \\
\hline $\begin{array}{r}6 \\
7 \\
8 \\
9 \\
10\end{array}$ & $\begin{array}{r}7.7 \\
8.0 \\
8.0 \\
8.3 \\
---\end{array}$ & $\begin{array}{r}6.7 \\
6.8 \\
6.9 \\
6.9 \\
--\end{array}$ & $\begin{array}{r}7.2 \\
7.4 \\
7.5 \\
7.6 \\
--\end{array}$ & $\begin{array}{l}7.9 \\
7.9 \\
7.7 \\
7.5 \\
7.3\end{array}$ & $\begin{array}{l}7.0 \\
7.0 \\
6.6 \\
6.5 \\
6.3\end{array}$ & $\begin{array}{l}7.4 \\
7.4 \\
7.1 \\
6.9 \\
6.7\end{array}$ & $\begin{array}{l}8.8 \\
7.7 \\
8.8 \\
9.1 \\
8.5\end{array}$ & $\begin{array}{l}5.5 \\
6.3 \\
7.1 \\
6.1 \\
5.9\end{array}$ & $\begin{array}{l}6.7 \\
7.0 \\
7.7 \\
7.6 \\
6.9\end{array}$ & $\begin{array}{l}9.3 \\
9.5 \\
9.3 \\
9.9 \\
9.9\end{array}$ & $\begin{array}{l}6.5 \\
6.4 \\
6.3 \\
6.2 \\
6.7\end{array}$ & $\begin{array}{l}7.7 \\
7.7 \\
7.3 \\
7.5 \\
7.9\end{array}$ \\
\hline $\begin{array}{l}11 \\
12 \\
13 \\
14 \\
15\end{array}$ & $\begin{array}{l}--- \\
--- \\
--- \\
--- \\
---\end{array}$ & $\begin{array}{l}--- \\
--- \\
--- \\
--- \\
---\end{array}$ & $\begin{array}{l}--- \\
--- \\
--- \\
---\end{array}$ & $\begin{array}{l}7.3 \\
7.5 \\
7.3 \\
7.6 \\
7.7\end{array}$ & $\begin{array}{l}6.3 \\
6.2 \\
6.2 \\
6.0 \\
6.0\end{array}$ & $\begin{array}{l}6.7 \\
6.8 \\
6.6 \\
6.7 \\
6.7\end{array}$ & $\begin{array}{l}8.3 \\
8.6 \\
8.3 \\
8.5 \\
8.5\end{array}$ & $\begin{array}{l}5.9 \\
6.0 \\
6.0 \\
5.8 \\
5.6\end{array}$ & $\begin{array}{l}6.7 \\
6.9 \\
6.9 \\
6.7 \\
6.9\end{array}$ & $\begin{array}{r}10.2 \\
10.8 \\
11.0 \\
9.6 \\
10.0\end{array}$ & $\begin{array}{l}6.8 \\
6.5 \\
6.1 \\
5.9 \\
5.9\end{array}$ & $\begin{array}{l}8.2 \\
8.4 \\
7.8 \\
7.3 \\
7.4\end{array}$ \\
\hline $\begin{array}{l}16 \\
17 \\
18 \\
19 \\
20\end{array}$ & $\begin{array}{l}--- \\
--- \\
-- \\
7.6 \\
8.2\end{array}$ & $\begin{array}{r}\ldots- \\
\cdots .5 \\
6.8\end{array}$ & $\begin{array}{l}--- \\
--- \\
--- \\
7.1 \\
7.4\end{array}$ & $\begin{array}{l}8.0 \\
7.8 \\
7.8 \\
7.9 \\
7.6\end{array}$ & $\begin{array}{l}6.1 \\
6.1 \\
6.2 \\
6.1 \\
6.0\end{array}$ & $\begin{array}{l}7.0 \\
6.8 \\
6.9 \\
6.9 \\
6.7\end{array}$ & $\begin{array}{l}8.8 \\
8.5 \\
8.2 \\
7.7 \\
7.7\end{array}$ & $\begin{array}{l}5.3 \\
5.3 \\
5.3 \\
5.7 \\
5.9\end{array}$ & $\begin{array}{l}6.7 \\
6.4 \\
6.3 \\
6.5 \\
6.6\end{array}$ & $\begin{array}{l}9.4 \\
9.8 \\
9.4 \\
8.9 \\
9.8\end{array}$ & $\begin{array}{l}5.7 \\
5.6 \\
5.5 \\
5.3 \\
5.2\end{array}$ & $\begin{array}{l}7.1 \\
7.1 \\
7.0 \\
6.7 \\
6.9\end{array}$ \\
\hline $\begin{array}{l}21 \\
22 \\
23 \\
24 \\
25\end{array}$ & $\begin{array}{r}7.8 \\
7.3 \\
7.2 \\
-- \\
8.1\end{array}$ & $\begin{array}{r}6.6 \\
6.5 \\
6.3 \\
-- \\
7.1\end{array}$ & $\begin{array}{r}7.1 \\
6.8 \\
6.7 \\
-- \\
7.6\end{array}$ & $\begin{array}{l}7.5 \\
7.7 \\
7.9 \\
8.6 \\
8.3\end{array}$ & $\begin{array}{l}5.9 \\
6.0 \\
6.1 \\
6.2 \\
6.3\end{array}$ & $\begin{array}{l}6.6 \\
6.6 \\
6.8 \\
7.1 \\
7.1\end{array}$ & $\begin{array}{l}8.8 \\
8.5 \\
8.8 \\
9.4 \\
9.7\end{array}$ & $\begin{array}{l}5.9 \\
6.2 \\
6.3 \\
6.5 \\
6.8\end{array}$ & $\begin{array}{l}7.0 \\
7.0 \\
7.2 \\
7.7 \\
7.8\end{array}$ & $\begin{array}{r}10.1 \\
9.9 \\
8.5 \\
9.6 \\
10.2\end{array}$ & $\begin{array}{l}6.4 \\
6.4 \\
6.4 \\
6.8 \\
7.5\end{array}$ & $\begin{array}{l}7.6 \\
7.5 \\
7.2 \\
8.0 \\
8.6\end{array}$ \\
\hline $\begin{array}{l}26 \\
27 \\
28 \\
29 \\
30 \\
31\end{array}$ & $\begin{array}{r}7.8 \\
7.7 \\
7.5 \\
7.5 \\
7.5 \\
--\end{array}$ & $\begin{array}{r}6.9 \\
6.8 \\
6.7 \\
6.8 \\
6.7 \\
---\end{array}$ & $\begin{array}{r}7.4 \\
7.2 \\
7.1 \\
7.2 \\
7.0 \\
--\end{array}$ & $\begin{array}{l}8.4 \\
8.4 \\
8.5 \\
8.5 \\
8.4 \\
8.5\end{array}$ & $\begin{array}{l}6.2 \\
6.1 \\
6.1 \\
6.1 \\
6.5 \\
6.5\end{array}$ & $\begin{array}{l}7.1 \\
7.0 \\
7.0 \\
6.8 \\
7.2 \\
7.3\end{array}$ & $\begin{array}{r}10.2 \\
10.0 \\
9.6 \\
9.5 \\
9.6 \\
9.6\end{array}$ & $\begin{array}{l}6.7 \\
6.4 \\
6.1 \\
5.8 \\
5.8 \\
5.7\end{array}$ & $\begin{array}{l}8.0 \\
7.8 \\
7.5 \\
7.3 \\
7.3 \\
7.3\end{array}$ & $\begin{array}{l}10.6 \\
10.5 \\
10.6 \\
10.8 \\
10.6 \\
-\end{array}$ & $\begin{array}{r}7.6 \\
7.2 \\
7.2 \\
6.8 \\
6.4 \\
---\end{array}$ & $\begin{array}{r}9.0 \\
8.6 \\
8.4 \\
8.6 \\
8.1 \\
--\end{array}$ \\
\hline $\mathrm{NTH}$ & -- &.- &.- & 8.6 & 5.9 & 6.9 & 10.2 & 5.3 & 7.1 & 11.0 & 5.2 & 7.7 \\
\hline
\end{tabular}


LOCATION.--Lat $34^{\circ} 14^{\prime} 33^{\prime \prime}$, long $97^{\circ} 04^{\prime} 05^{\prime \prime}$, in NW 1/4 NW 1/4 sec.2, T.4 S., R.2 E., Carter County, Hydrologic Unit 11130303, on

right bank 0.9 mi above Sand Creek, 4.8 mi northeast of Ardmore, and at mi 11.1.

PERIOD OF RECORD.--October 1996 to August 1997 (discontinued).

REMARKS.--Water temperature, specific conductance, $\mathrm{pH}$, alkalinity, and dissolved oxygen were determined in the field.

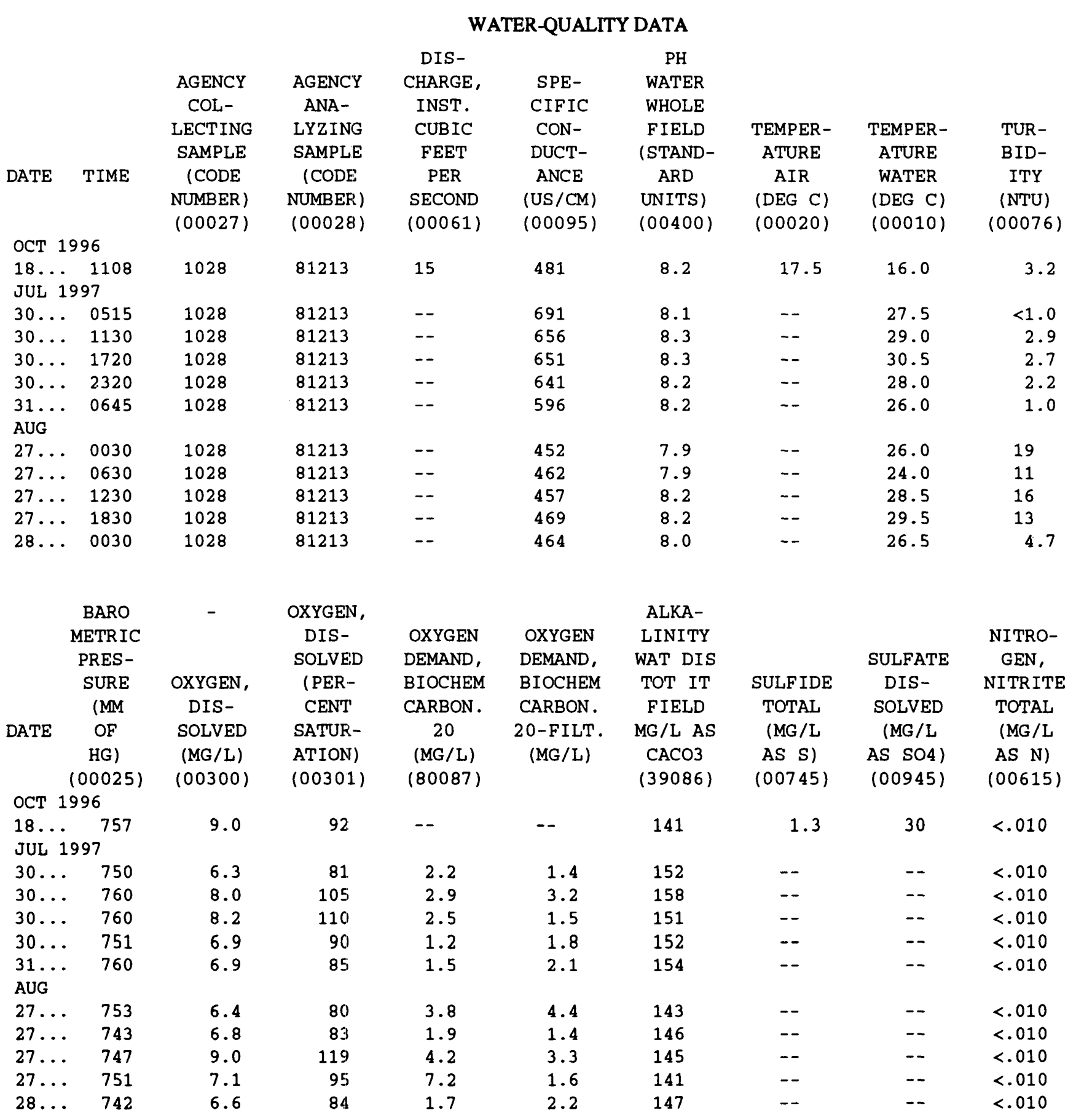


WATER-QUALITY DATA

\begin{tabular}{|c|c|c|c|c|c|c|c|c|c|}
\hline DATE & $\begin{array}{c}\text { NITRO- } \\
\text { GEN, } \\
\text { NO2+NO3 } \\
\text { TOTAL } \\
\text { (MG/L } \\
\text { AS N) } \\
(00630)\end{array}$ & $\begin{array}{l}\text { NITRO- } \\
\text { GEN, } \\
\text { AMMONIA } \\
\text { TOTAL } \\
\text { (MG/L } \\
\text { AS N) } \\
(00610)\end{array}$ & $\begin{array}{l}\text { NITRO- } \\
\text { GEN, } \\
\text { AMMONIA } \\
\text { TOTAL } \\
\text { (MG/L } \\
\text { AS NH4) } \\
(71845)\end{array}$ & $\begin{array}{l}\text { NITRO- } \\
\text { GEN, } \\
\text { ORGANIC } \\
\text { TOTAL } \\
\text { (MG/L } \\
\text { AS N) } \\
(00605)\end{array}$ & $\begin{array}{l}\text { NITRO- } \\
\text { GEN, AM- } \\
\text { MONIA + } \\
\text { ORGANIC } \\
\text { TOTAL } \\
\text { (MG/L } \\
\text { AS N) } \\
(00625)\end{array}$ & $\begin{array}{c}\text { PHOS- } \\
\text { PHORUS } \\
\text { TOTAL } \\
\text { (MG/L } \\
\text { AS P) } \\
(00665)\end{array}$ & $\begin{array}{c}\text { PHOS- } \\
\text { PHORUS } \\
\text { HYDRO. } \\
+ \text { ORTHO } \\
\text { TOTAL } \\
\text { (MG/L } \\
\text { AS P) } \\
(00678)\end{array}$ & $\begin{array}{l}\text { PHENOLS } \\
\text { TOTAL } \\
\text { (UG/L) } \\
(32730)\end{array}$ & $\begin{array}{l}\text { CHLOR-A } \\
\text { PHYTO- } \\
\text { PLANK- } \\
\text { TON } \\
\text { CHROMO } \\
\text { FLUOROM } \\
\text { (UG/L) } \\
(70953)\end{array}$ \\
\hline OCT & 1996 & & & & & & & & \\
\hline $\begin{array}{l}18 . . \\
\text { JUL }\end{array}$ & $\begin{array}{l}-<.020 \\
1997\end{array}$ & .050 & .06 & -- & $<.20$ & .030 & .02 & $<1$ & .400 \\
\hline $30 .$. &.$<.020$ & .030 & .04 & .27 & .30 & $<.020$ & .12 & -- & 1.30 \\
\hline $30 .$. &.$<.020$ & .040 & .05 & .26 & .30 & .070 & .03 & -- & 1.10 \\
\hline $30 .$. &.$<.020$ & .030 & .04 & .27 & .30 & $<.020$ & .03 & -- & 1.20 \\
\hline $30 .$. &.$<.020$ & .030 & .04 & .40 & .43 & $<.020$ & .03 & -- & 1.00 \\
\hline $\begin{array}{l}31 \ldots \\
\text { AUG }\end{array}$ & . $<.020$ & .030 & .04 & .31 & .34 & .060 & .02 & -- & 1.20 \\
\hline $27 \ldots$ &.$<.020$ & .020 & .03 & .55 & .57 & $<.020$ & $<.01$ & -. & 1.00 \\
\hline $27 \ldots$ &.$<.020$ & .020 & .03 & .31 & .33 & $<.020$ & $<.01$ & -- & 1.10 \\
\hline $27 .$. & . $<.020$ & .050 & .06 & .68 & .73 & $<.020$ & $<.01$ & -- & 1.50 \\
\hline $27 .$. &.$<.020$ & .020 & .03 & .46 & .48 & $<.020$ & $<.01$ & -- & 2.30 \\
\hline $28 \ldots$ &.$<.020$ & .020 & .03 & .42 & .44 & .030 & $<.01$ & -- & 1.40 \\
\hline
\end{tabular}




\section{SAND CREEK SITE 1, POINT SOURCE FROM WASTEWATER PLANT NEAR ARDMORE, OK}

LOCATION.--Lat $34^{\circ} 12^{\prime} 28^{\prime \prime}$, long 97 $05^{\prime} 47^{\prime \prime}$, in SW 1/4 NE 1/4 sec.16, T.4 S., R.2 E., Carter County, Hydrologic Unit 11130303, on left bank at south edge of Ardmore Wastewater Treatment plant, northeast of Ardmore, and at mile 4.8.

DRAINAGE AREA.--6.9 $\mathrm{mi}^{2}$.

PERIOD OF RECORD.--April to August 1997 (gage heights only) (discontinued).

GAGE.--Water-stage recorder. Datum of gage is $860 \mathrm{ft}$ above sea level from topographic map.

REMARKS.--Records fair. Low stages could be effected by backwater from the Ardmore Waste Water Treatment plant releases downstream.

EXTREMES FOR CURRENT PERIOD.--Maximum gage height, $8.64 \mathrm{ft}$, June 9; minimum, .30 ft, July 11.

GAGE HEIGHT, FEET, WATER YEAR OCTOBER 1996 TO SEPTEMBER 1997

\begin{tabular}{|c|c|c|c|c|c|c|c|c|c|c|c|c|}
\hline DAY & MAX & $\begin{array}{l}\text { MIN } \\
\text { BRUA }\end{array}$ & MEAN & MAX & $\begin{array}{r}\text { MIN } \\
\text { MARCF }\end{array}$ & MEAN & MAX & $\begin{array}{c}\text { MIN } \\
\text { APRIL }\end{array}$ & MEAN & MAX & $\begin{array}{l}\text { MIN } \\
\text { MAY }\end{array}$ & MEAN \\
\hline 1 & -- & --- & --- & -- & --- & --- & -- & --- & -- & .97 & .65 & .86 \\
\hline 2 & $-\cdots$ & --- & -- & --- & --- & --- & --- & --- & -- & .95 & .51 & .77 \\
\hline 3 & --- & --- & --- & --- & --- & --- & --- & --- & --- & .80 & .61 & .72 \\
\hline 4 & -- & --- & --- & --- & --- & --- & --- & --- & --- & .79 & .60 & .71 \\
\hline 5 & --- & --- & --- & -- & --- & --- & --- & -- & --- & .80 & .60 & .72 \\
\hline 6 & -- & --- & -- & -- & --- & -- & -- & -- & -- & .86 & .65 & .77 \\
\hline 7 & --- & --- & --- & --- & --- & --- & --- & -- & -- & .87 & .75 & .81 \\
\hline 8 & -- & --- & --- & --- & --- & --- & --- & --- & $\cdots$ & 1.09 & .74 & .85 \\
\hline 9 & -- & --- & --- & --- & --- & --- & .91 & .79 & .85 & 1.91 & .75 & 1.11 \\
\hline 10 & -- & --- & --- & --- & --- & --- & .97 & .56 & .75 & .97 & .77 & .84 \\
\hline 11 & --- & --- & --- & -- & --- & --- & 4.27 & .78 & 2.12 & .87 & .69 & .78 \\
\hline 12 & --- & --- & --- & $\cdots$ & --- & --- & 1.64 & .99 & 1.20 & .84 & .67 & .76 \\
\hline 13 & -- & -- & --- & --- & --- & -- & 1.01 & .88 & .93 & .90 & .70 & .82 \\
\hline 14 & -- & -- & --- & --- & --- & -- & .91 & .80 & .86 & .87 & .68 & .77 \\
\hline 15 & --- & -- & --- & --- & --- & --- & .86 & .75 & .82 & .96 & .54 & .76 \\
\hline 16 & --- & --- & --- & --- & --- & --- & .86 & .72 & .79 & .95 & .55 & .75 \\
\hline 17 & -- & -- & --- & -- & --- & --- & .97 & .61 & .78 & .85 & .57 & .71 \\
\hline 18 & --- & --- & -- & --- & --- & --- & .95 & .75 & .82 & .81 & .65 & .74 \\
\hline 19 & --- & --- & --- & --- & -- & --- & .84 & .70 & .78 & 4.20 & .65 & 1.65 \\
\hline 20 & --- & --- & $\cdots$ & $\cdots$ & --- & -- & .89 & .68 & .79 & 4.06 & 1.42 & 2.18 \\
\hline 21 & -. & --- & --- & -- & -- & --- & .88 & .75 & .83 & 1.43 & 1.06 & 1.22 \\
\hline 22 & --- & --- & -- & $\ldots$ & --- & $\cdots$ & 1.23 & .71 & .93 & 1.09 & .74 & .97 \\
\hline 23 & --- & $\cdots$ & --- & -- & --- & -- & 1.12 & .78 & .86 & 1.00 & .70 & .90 \\
\hline 24 & -- & -- & --- & --- & --- & --- & .91 & .75 & .83 & 1.01 & .83 & .91 \\
\hline 25 & --- & --- & -- & $\cdots$ & --- & --- & 3.57 & .81 & 1.49 & 1.57 & .75 & .84 \\
\hline 26 & --- & --- & --- & --- & --- & --- & 1.96 & 1.24 & 1.59 & 1.53 & .81 & .92 \\
\hline 27 & -- & -- & -- & --- & -- & -- & 1.50 & 1.10 & 1.32 & .87 & .68 & .77 \\
\hline 28 & --- & -- & --- & --- & -- & -- & 1.11 & .94 & 1.00 & .82 & .65 & .75 \\
\hline 29 & --- & -- & -- & $\cdots$ & -- & -- & .96 & .80 & .86 & .89 & .38 & .63 \\
\hline 30 & $\cdots$ & --- & --- & --- & --- & --- & .93 & .78 & .86 & 6.78 & .72 & 2.29 \\
\hline 31 & -- & -- & -- & --- & --- & --- & -- & -- & -- & 1.57 & .94 & 1.19 \\
\hline 1ONTH & --- & --- & --- & --- & -- & --- & --- & -- & --- & 6.78 & .38 & .95 \\
\hline
\end{tabular}


07330615 SAND CREEK SITE 1, POINT SOURCE FROM WASTEWATER PLANT NEAR ARDMORE, OK--Continued

GAGE HEIGHT, FEET, WATER YEAR OCTOBER 1996 TO SEPTEMBER 1997

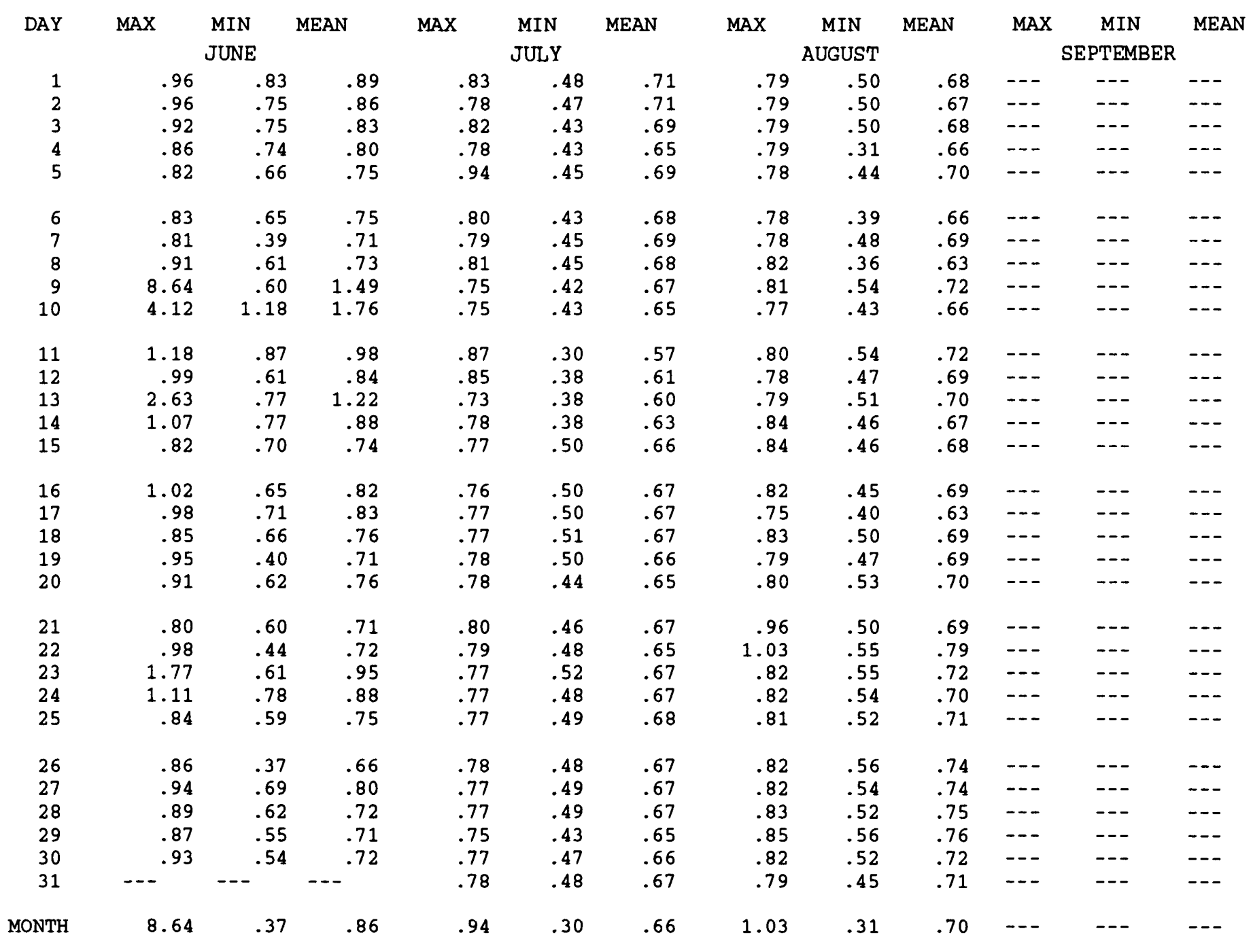




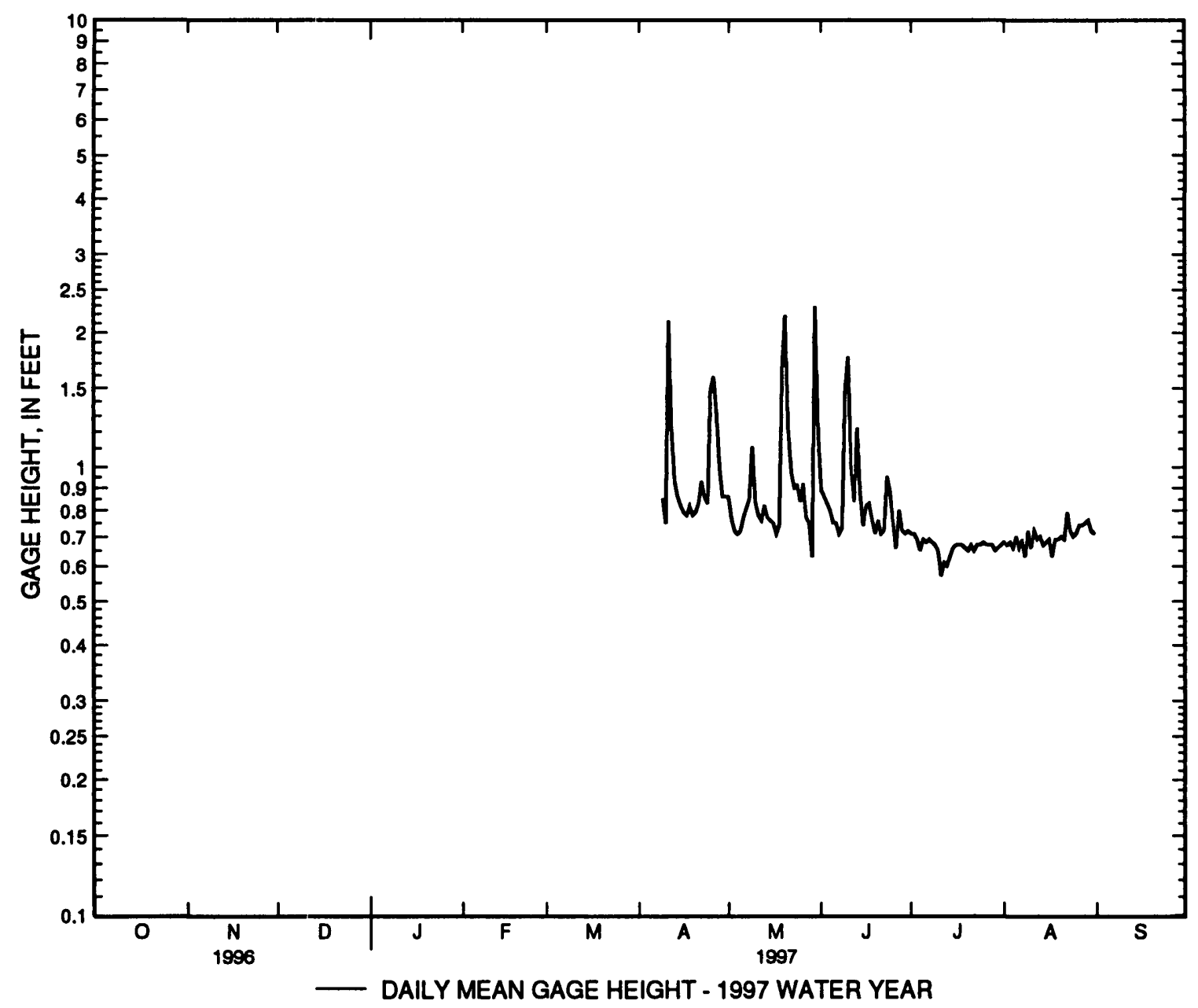




\section{WATER-QUALITY RECORDS}

PERIOD OF RECORD.--April 1997 to September 1997 (discontinued).

PERIOD OF DAILY RECORD.--

SPECIFIC CONDUCTANCE: April 1997 to September 1997 (discontinued).

WATER TEMPERATURE: April 1997 to September 1997 (discontinued).

REMARKS.--Water temperature, specific conductance, $\mathrm{pH}$, alkalinity, and dissolved oxygen were determined in the field.

INSTRUMENTATION.--Water-quality monitor since April 1997.

EXTREMES FOR CURRENT YEAR (April 1997 to September 1997).--

SPECIFIC CONDUCTANCE: Maximum, 5980 microsiemens, Aug. 2; minimum, 103 microsiemens, May 19.

WATER TEMPERATURE: Maximum, 33.0 $0^{\circ} \mathrm{C}$, July 27,28; minimum, $10.0^{\circ} \mathrm{C}$, Apr. 13.

WATER-QUALITY DATA

\begin{tabular}{|c|c|c|c|c|c|c|c|c|c|}
\hline DATE & TIME & $\begin{array}{c}\text { AGENCY } \\
\text { COL- } \\
\text { LECTING } \\
\text { SAMPLE } \\
\text { (CODE } \\
\text { NUMBER) } \\
(00027)\end{array}$ & $\begin{array}{l}\text { AGENCY } \\
\text { ANA- } \\
\text { LYZING } \\
\text { SAMPLE } \\
\text { (CODE } \\
\text { NUMBER) } \\
(00028)\end{array}$ & $\begin{array}{l}\text { SPE- } \\
\text { CIFIC } \\
\text { CON- } \\
\text { DUCT- } \\
\text { ANCE } \\
\text { (US/CM) } \\
(00095)\end{array}$ & $\begin{array}{c}\text { PH } \\
\text { WATER } \\
\text { WHOLE } \\
\text { FIELD } \\
\text { (STAND- } \\
\text { ARD } \\
\text { UNITS) } \\
(00400)\end{array}$ & $\begin{array}{c}\text { TEMPER- } \\
\text { ATURE } \\
\text { WATER } \\
\text { (DEG C) } \\
(00010)\end{array}$ & $\begin{array}{c}\text { TUR- } \\
\text { BID- } \\
\text { ITY } \\
\text { (NTU) } \\
(00076)\end{array}$ & $\begin{array}{c}\text { BARO- } \\
\text { METRIC } \\
\text { PRES- } \\
\text { SURE } \\
\text { (MM } \\
\text { OF } \\
\text { HG) } \\
(00025)\end{array}$ & $\begin{array}{c}\text { OXYGEN, } \\
\text { DIS- } \\
\text { SOLVED } \\
\text { (MG/L) } \\
(00300)\end{array}$ \\
\hline $\begin{array}{l}\text { OCT } \\
18 \ldots \\
\text { JUL }\end{array}$ & $\begin{array}{c}1996 \\
0830 \\
1997\end{array}$ & 1028 & 81213 & 4370 & 7.2 & 16.5 & 26 & 753 & 3.8 \\
\hline $29 \ldots$ & 0601 & 1028 & 81213 & 5730 & 7.0 & 28.5 & 13 & 750 & 3.5 \\
\hline $29 \ldots$ & 1203 & 1028 & 81213 & 6010 & 7.5 & 30.5 & 5.5 & 750 & 5.4 \\
\hline $\begin{array}{l}29 \ldots \\
30 .\end{array}$ & $\begin{array}{l}1810 \\
0015\end{array}$ & $\begin{array}{l}1028 \\
1028\end{array}$ & $\begin{array}{l}81213 \\
81213\end{array}$ & $\begin{array}{l}5740 \\
5740\end{array}$ & $\begin{array}{l}7.4 \\
7.1\end{array}$ & $\begin{array}{l}29.0 \\
28.0\end{array}$ & $\begin{array}{r}<1.0 \\
6.4\end{array}$ & $\begin{array}{l}750 \\
750\end{array}$ & $\begin{array}{l}5.1 \\
3.6\end{array}$ \\
\hline $\begin{array}{l}30 \ldots \\
\text { AUG }\end{array}$ & 0610 & 1028 & 81213 & 5760 & 7.0 & 27.0 & 2.2 & 752 & 3.3 \\
\hline $26 \ldots$ & 0600 & 1028 & 81213 & 5400 & 7.0 & 25.0 & 7.1 & 752 & 3.6 \\
\hline $26 \ldots$ & 1200 & 1028 & 81213 & 5390 & 8.5 & 28.0 & 5.9 & 752 & 10.5 \\
\hline $26 \ldots$ & 1800 & 1028 & 81213 & 5280 & 8.9 & 30.0 & 8.0 & 747 & 11.5 \\
\hline $27 \ldots$ & 0030 & 1028 & 81213 & 5320 & 7.4 & 26.5 & 7.7 & 752 & 4.1 \\
\hline $27 \ldots$ & 0600 & 1028 & 81213 & 5170 & 7.1 & 25.5 & 7.5 & 753 & 3.0 \\
\hline DATE & $\begin{array}{c}\text { OXYGEN } \\
\text { DEMAND, } \\
\text { BIOCHEM } \\
\text { CARBON. } \\
20 \\
(\mathrm{MG} / \mathrm{L}) \\
(80087)\end{array}$ & $\begin{array}{c}\text { OXYGEN } \\
\text { DEMAND, } \\
\text { BIOCHEM } \\
\text { CARBON. } \\
\text { 20-FILT. } \\
\text { (MG/L) }\end{array}$ & $\begin{array}{c}\text { ALKA- } \\
\text { LINITY } \\
\text { WAT DIS } \\
\text { TOT IT } \\
\text { FIELD } \\
\text { MG/L AS } \\
\text { CACO3 } \\
(39086)\end{array}$ & $\begin{array}{c}\text { SULFIDE } \\
\text { TOTAL } \\
\text { (MG/L } \\
\text { AS S) } \\
(00745)\end{array}$ & $\begin{array}{c}\text { SULFATE } \\
\text { DIS- } \\
\text { SOLVED } \\
\text { (MG/L } \\
\text { AS SO4) } \\
(00945)\end{array}$ & $\begin{array}{c}\text { NITRO- } \\
\text { GEN, } \\
\text { NITRATE } \\
\text { TOTAL } \\
\text { (MG/L } \\
\text { AS N) } \\
(00620)\end{array}$ & $\begin{array}{l}\text { NITRO- } \\
\text { GEN, } \\
\text { NITRITE } \\
\text { TOTAL } \\
\text { (MG /L } \\
\text { AS N) } \\
(00615)\end{array}$ & $\begin{array}{c}\text { NITRO- } \\
\text { GEN, } \\
\text { NO2+NO3 } \\
\text { TOTAL } \\
\text { (MG/L } \\
\text { AS N) } \\
(00630)\end{array}$ & $\begin{array}{l}\text { NITRO- } \\
\text { GEN, } \\
\text { AMMONIA } \\
\text { TOTAL } \\
\text { (MG /L } \\
\text { AS N) } \\
(00610)\end{array}$ \\
\hline OCT & 1996 & & & & & & & & \\
\hline $\begin{array}{l}18 \ldots \\
\text { JUL }\end{array}$ & $997^{--}$ & -- & 68 & $<1.0$ & 310 & 1.10 & 1.00 & 2.10 & 4.30 \\
\hline $29 \ldots$ & 5.9 & 4.4 & 32 & -- & -- & .270 & .270 & .540 & 1.40 \\
\hline $29 \ldots$ & 8.0 & 5.0 & 42 & - & -- & .260 & .260 & .520 & 1.40 \\
\hline $29 \ldots$ & 6.8 & 4.4 & 36 & -- & -- & .600 & 1.30 & 1.90 & .360 \\
\hline $30 \ldots$ & 7.7 & 4.8 & 42 & -- & -- & .310 & .300 & .610 & 1.50 \\
\hline $\begin{array}{l}30 \ldots \\
\text { AUG }\end{array}$ & 8.1 & 3.2 & 40 & -- & -- & .250 & .280 & .530 & 1.90 \\
\hline $26 \ldots$ & 8.8 & 3.8 & 38 & -- & -- & .660 & .340 & 1.00 & .860 \\
\hline $26 \ldots$ & 11 & 3.2 & 36 & -- & -- & .740 & .360 & 1.10 & .620 \\
\hline $26 \ldots$ & 13 & 3.0 & 37 & -- & -- & .760 & .340 & 1.10 & .280 \\
\hline $27 \ldots$ & 9.6 & 3.0 & 37 & -- & -- & .750 & .350 & 1.10 & .750 \\
\hline $27 \ldots$ & 8.4 & 2.6 & 39 & -- & -- & .680 & .320 & 1.00 & .830 \\
\hline
\end{tabular}


WATER-QUALITY DATA

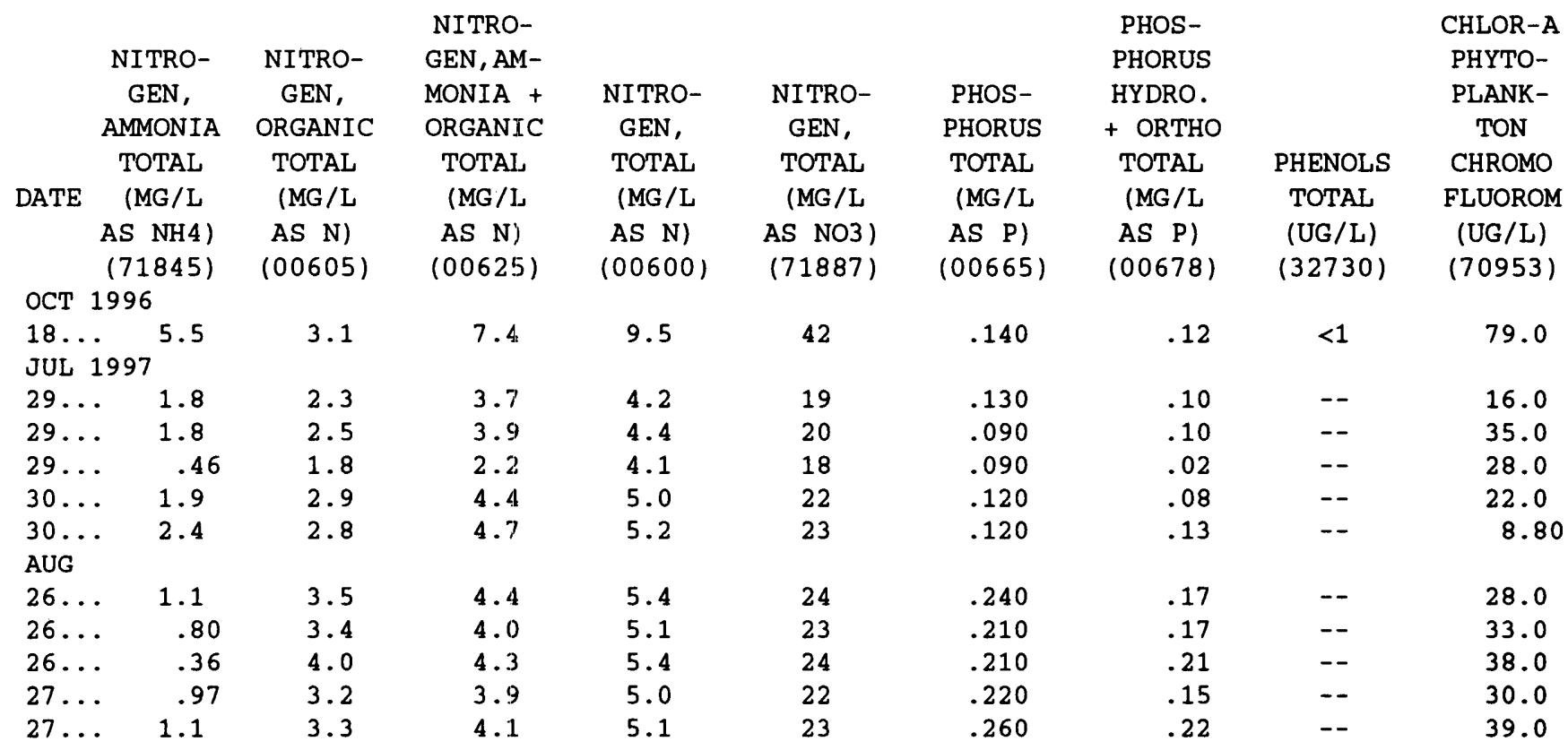

SPECIFIC CONDUCTANCE, US/CM @ 25 DEGREES CELSIUS, WATER YEAR OCTOBER 1996 TO SEPTEMBER 1997

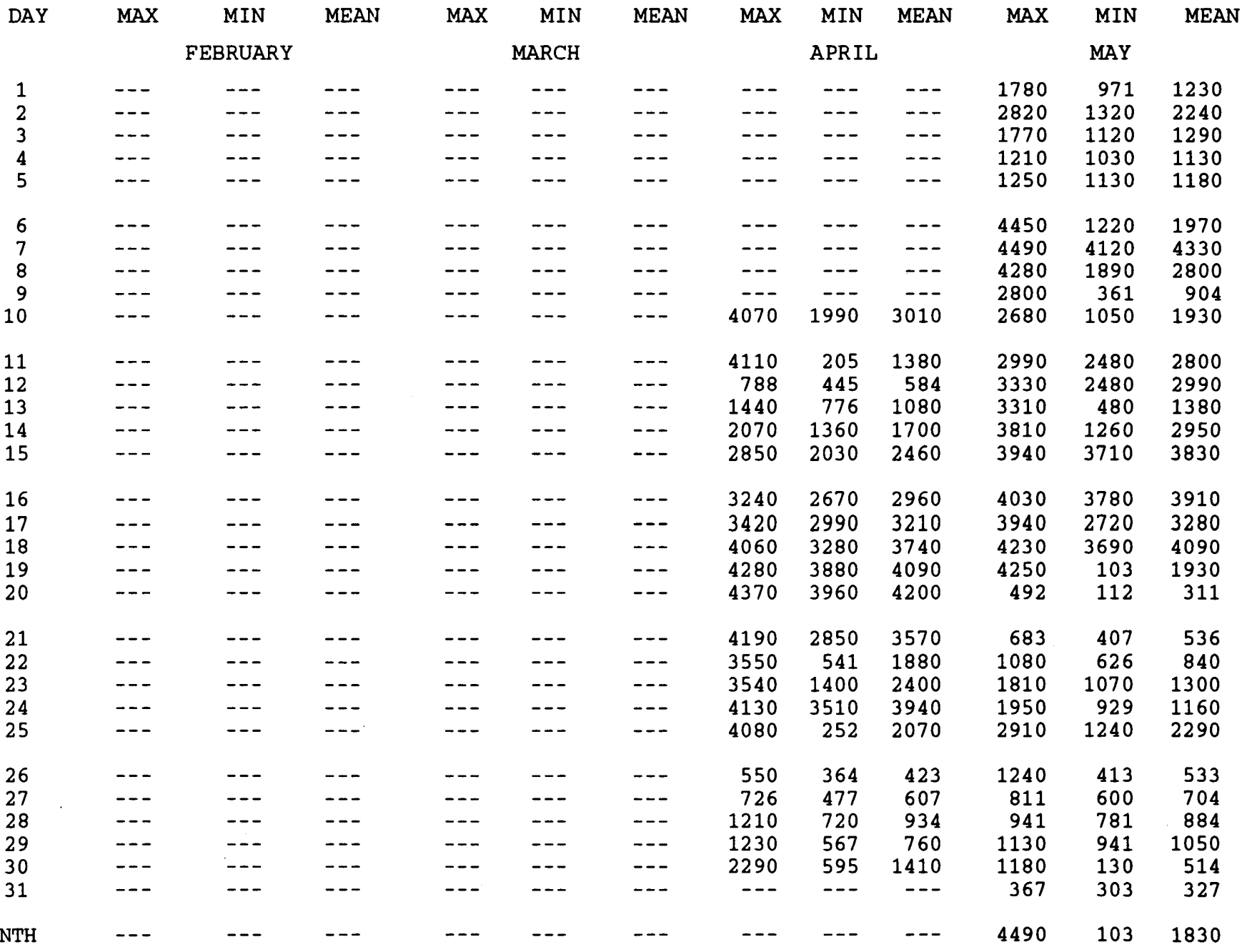


07330615 SAND CREEK SITE 1, POINT SOURCE FROM WASTEWATER PLANT NEAR ARDMORE, OK--Continued SPECIFIC CONDUCTANCE, US/CM @ 25 DEGREES CELSIUS, WATER YEAR OCTOBER 1996 TO SEPTEMBER 1997

\begin{tabular}{|c|c|c|c|c|c|c|c|c|c|c|c|c|}
\hline \multirow[t]{2}{*}{ DAY } & MAX & MIN & MEAN & MAX & MIN & MEAN & MAX & MIN & MEAN & MAX & MIN & MEAN \\
\hline & & JUNE & & \multicolumn{3}{|c|}{ JULY } & \multicolumn{3}{|c|}{ AUGUST } & \multicolumn{3}{|c|}{ SEPTEMBER } \\
\hline $\begin{array}{l}1 \\
2 \\
3 \\
4 \\
5\end{array}$ & $\begin{array}{r}497 \\
731 \\
816 \\
879 \\
1240\end{array}$ & $\begin{array}{l}367 \\
488 \\
543 \\
795 \\
850\end{array}$ & $\begin{array}{l}436 \\
559 \\
657 \\
835 \\
990\end{array}$ & $\begin{array}{l}1200 \\
1210 \\
1250 \\
1250 \\
1300\end{array}$ & $\begin{array}{r}890 \\
1170 \\
1180 \\
1160 \\
1190\end{array}$ & $\begin{array}{l}1070 \\
1190 \\
1220 \\
1210 \\
1240\end{array}$ & $\begin{array}{l}5880 \\
5980 \\
5960 \\
5880 \\
3660\end{array}$ & $\begin{array}{l}5730 \\
5810 \\
5800 \\
3390 \\
2200\end{array}$ & $\begin{array}{l}5790 \\
5880 \\
5860 \\
5250 \\
2640\end{array}$ & $\begin{array}{r}2110 \\
1910 \\
2510 \\
459 \\
843\end{array}$ & $\begin{array}{r}1660 \\
1600 \\
273 \\
300 \\
459\end{array}$ & $\begin{array}{r}1920 \\
1770 \\
1370 \\
400 \\
660\end{array}$ \\
\hline $\begin{array}{r}6 \\
7 \\
8 \\
9 \\
10\end{array}$ & $\begin{array}{r}1420 \\
1510 \\
1570 \\
1620 \\
401\end{array}$ & $\begin{array}{r}1240 \\
1420 \\
1510 \\
142 \\
205\end{array}$ & $\begin{array}{r}1300 \\
1450 \\
1540 \\
1400 \\
331\end{array}$ & $\begin{array}{l}1260 \\
1310 \\
1380 \\
1470 \\
1410\end{array}$ & $\begin{array}{l}1200 \\
1230 \\
1290 \\
1320 \\
1360\end{array}$ & $\begin{array}{l}1240 \\
1270 \\
1320 \\
1370 \\
1390\end{array}$ & $\begin{array}{l}2720 \\
5910 \\
5920 \\
5850 \\
5790\end{array}$ & $\begin{array}{l}1630 \\
2720 \\
4940 \\
5500 \\
4800\end{array}$ & $\begin{array}{l}1960 \\
5540 \\
5770 \\
5690 \\
5520\end{array}$ & $\begin{array}{r}993 \\
1100 \\
1150 \\
1150 \\
---\end{array}$ & $\begin{array}{r}763 \\
970 \\
1070 \\
1110 \\
---\end{array}$ & $\begin{array}{r}896 \\
1040 \\
1100 \\
1130 \\
---\end{array}$ \\
\hline $\begin{array}{l}11 \\
12 \\
13 \\
14 \\
15\end{array}$ & $\begin{array}{l}447 \\
523 \\
749 \\
428 \\
504\end{array}$ & $\begin{array}{l}369 \\
447 \\
229 \\
377 \\
423\end{array}$ & $\begin{array}{l}395 \\
490 \\
390 \\
397 \\
463\end{array}$ & $\begin{array}{l}1410 \\
1390 \\
1400 \\
3640 \\
4770\end{array}$ & $\begin{array}{l}1230 \\
1130 \\
1190 \\
1150 \\
3640\end{array}$ & $\begin{array}{l}1350 \\
1290 \\
1300 \\
1690 \\
4500\end{array}$ & $\begin{array}{l}5760 \\
5590 \\
5500 \\
5510 \\
5550\end{array}$ & $\begin{array}{l}5590 \\
5370 \\
5370 \\
5330 \\
5400\end{array}$ & $\begin{array}{l}5670 \\
5500 \\
5440 \\
5420 \\
5480\end{array}$ & $\begin{array}{l}--- \\
--- \\
--- \\
---\end{array}$ & $\begin{array}{l}--- \\
--- \\
--- \\
---\end{array}$ & $\begin{array}{l}--- \\
--- \\
--- \\
---\end{array}$ \\
\hline $\begin{array}{l}16 \\
17 \\
18 \\
19 \\
20\end{array}$ & $\begin{array}{r}906 \\
1010 \\
700 \\
965 \\
1170\end{array}$ & $\begin{array}{l}490 \\
545 \\
560 \\
700 \\
965\end{array}$ & $\begin{array}{r}610 \\
834 \\
624 \\
805 \\
1080\end{array}$ & $\begin{array}{l}4860 \\
4910 \\
5140 \\
5280 \\
5350\end{array}$ & $\begin{array}{l}4720 \\
4700 \\
4890 \\
5100 \\
4810\end{array}$ & $\begin{array}{l}4780 \\
4850 \\
4980 \\
5190 \\
5210\end{array}$ & $\begin{array}{l}5530 \\
2840 \\
5840 \\
5810 \\
5810\end{array}$ & $\begin{array}{l}2680 \\
1530 \\
1730 \\
2790 \\
5700\end{array}$ & $\begin{array}{l}4350 \\
1970 \\
5400 \\
4820 \\
5770\end{array}$ & $\begin{array}{l}--- \\
--- \\
--- \\
---\end{array}$ & $\begin{array}{l}--- \\
--- \\
--- \\
---\end{array}$ & $\begin{array}{l}--- \\
--- \\
--- \\
--- \\
---\end{array}$ \\
\hline $\begin{array}{l}21 \\
22 \\
23 \\
24 \\
25\end{array}$ & $\begin{array}{r}1250 \\
1310 \\
1270 \\
776 \\
899\end{array}$ & $\begin{array}{r}1170 \\
1150 \\
312 \\
449 \\
776\end{array}$ & $\begin{array}{r}1220 \\
1270 \\
961 \\
640 \\
853\end{array}$ & $\begin{array}{l}5510 \\
5560 \\
5690 \\
5720 \\
5480\end{array}$ & $\begin{array}{l}5280 \\
5440 \\
5480 \\
5350 \\
5350\end{array}$ & $\begin{array}{l}5390 \\
5490 \\
5580 \\
5540 \\
5410\end{array}$ & $\begin{array}{l}5780 \\
5530 \\
4960 \\
5320 \\
5440\end{array}$ & $\begin{array}{l}5530 \\
2520 \\
3310 \\
4950 \\
5310\end{array}$ & $\begin{array}{l}5610 \\
4350 \\
4350 \\
5160 \\
5360\end{array}$ & $\begin{array}{l}--- \\
--- \\
--- \\
---\end{array}$ & $\begin{array}{l}--- \\
--- \\
--- \\
---\end{array}$ & $\begin{array}{l}--- \\
--- \\
--- \\
---\end{array}$ \\
\hline $\begin{array}{l}26 \\
27 \\
28 \\
29 \\
30 \\
31\end{array}$ & $\begin{array}{r}942 \\
687 \\
805 \\
913 \\
1070 \\
---\end{array}$ & $\begin{array}{l}687 \\
494 \\
657 \\
777 \\
865 \\
---\end{array}$ & $\begin{array}{l}883 \\
587 \\
730 \\
840 \\
9.43 \\
---\end{array}$ & $\begin{array}{l}5530 \\
5590 \\
5640 \\
5620 \\
5740 \\
5810\end{array}$ & $\begin{array}{l}5380 \\
5470 \\
5520 \\
4370 \\
5530 \\
5650\end{array}$ & $\begin{array}{l}5450 \\
5520 \\
5580 \\
5310 \\
5630 \\
5720\end{array}$ & $\begin{array}{l}5420 \\
5340 \\
5230 \\
5090 \\
5030 \\
2580\end{array}$ & $\begin{array}{l}5280 \\
5190 \\
5080 \\
5000 \\
2560 \\
2040\end{array}$ & $\begin{array}{l}5370 \\
5250 \\
5140 \\
5030 \\
4130 \\
2280\end{array}$ & $\begin{array}{l}--- \\
--- \\
--- \\
--- \\
---\end{array}$ & $\begin{array}{l}--- \\
-- \\
--- \\
--- \\
---\end{array}$ & $\begin{array}{l}--\cdot \\
--- \\
--- \\
--- \\
---\end{array}$ \\
\hline NTH & 1620 & 142 & 817 & 5810 & 890 & 3490 & 5980 & 1530 & 4900 & -.. & -. & -.- \\
\hline
\end{tabular}


07330615 SAND CREEK SITE 1, POINT SOURCE FROM WASTEWATER PLANT NEAR ARDMORE, OK--Continued

WATER TEMPERATURE, DEGREES CELSIUS, WATER YEAR OCTOBER 1996 TO SEPTEMBER 1997

\begin{tabular}{|c|c|c|c|c|c|c|c|c|c|c|c|c|}
\hline DAY & MAX & $\begin{array}{r}\text { MIN } \\
\text { BRUAI }\end{array}$ & MEAN & MAX & $\begin{array}{r}\text { MIN } \\
\text { MARCH }\end{array}$ & MEAN & MAX & $\begin{array}{c}\text { MIN } \\
\text { APRIL }\end{array}$ & MEAN & MAX & $\begin{array}{l}\text { MIN } \\
\text { MAY }\end{array}$ & MEAN \\
\hline $\begin{array}{l}1 \\
2 \\
3 \\
4 \\
5\end{array}$ & $\begin{array}{l}--- \\
--- \\
--- \\
--- \\
--\end{array}$ & $\begin{array}{l}--- \\
--- \\
--- \\
--- \\
---\end{array}$ & $\begin{array}{l}--- \\
--- \\
--- \\
--- \\
---\end{array}$ & $\begin{array}{l}--- \\
--- \\
--- \\
--- \\
---\end{array}$ & $\begin{array}{l}--- \\
--- \\
--- \\
---\end{array}$ & $\begin{array}{l}--- \\
--- \\
--- \\
--- \\
---\end{array}$ & $\begin{array}{l}--- \\
--- \\
--- \\
---\end{array}$ & $\begin{array}{l}--- \\
--- \\
--- \\
---\end{array}$ & $\begin{array}{l}--- \\
--- \\
--- \\
---\end{array}$ & $\begin{array}{l}23.5 \\
25.5 \\
22.5 \\
22.0 \\
24.0\end{array}$ & $\begin{array}{l}17.0 \\
20.0 \\
16.5 \\
15.5 \\
18.0\end{array}$ & $\begin{array}{l}20.0 \\
22.0 \\
19.0 \\
19.0 \\
20.5\end{array}$ \\
\hline $\begin{array}{r}6 \\
7 \\
8 \\
9 \\
10\end{array}$ & $\begin{array}{l}--- \\
--- \\
--- \\
--- \\
--\end{array}$ & $\begin{array}{l}-- \\
--- \\
--- \\
---\end{array}$ & $\begin{array}{l}--- \\
--- \\
--- \\
---\end{array}$ & $\begin{array}{l}--- \\
--- \\
--- \\
---\end{array}$ & $\begin{array}{l}--- \\
--- \\
--- \\
---\end{array}$ & $\begin{array}{l}--- \\
--- \\
--- \\
---\end{array}$ & $\begin{array}{l}--- \\
--- \\
--- \\
-- \\
20.5\end{array}$ & $\begin{array}{l}--- \\
--- \\
--- \\
-- \\
14.0\end{array}$ & $\begin{array}{l}--- \\
--- \\
--- \\
-\overline{16.5}\end{array}$ & $\begin{array}{l}25.0 \\
25.0 \\
24.5 \\
23.0 \\
24.0\end{array}$ & $\begin{array}{l}20.5 \\
21.5 \\
21.0 \\
19.5 \\
17.0\end{array}$ & $\begin{array}{l}22.5 \\
23.0 \\
23.0 \\
21.0 \\
20.0\end{array}$ \\
\hline $\begin{array}{l}11 \\
12 \\
13 \\
14 \\
15\end{array}$ & $\begin{array}{l}--- \\
--- \\
--- \\
--- \\
---\end{array}$ & $\begin{array}{l}-- \\
-- \\
-- \\
--\end{array}$ & $\begin{array}{l}--- \\
--- \\
--- \\
---\end{array}$ & $\begin{array}{l}--- \\
--- \\
--- \\
---\end{array}$ & $\begin{array}{l}--- \\
--- \\
--- \\
--- \\
--\end{array}$ & $\begin{array}{l}--- \\
--- \\
-- \\
--- \\
--\end{array}$ & $\begin{array}{l}18.0 \\
15.5 \\
17.0 \\
19.0 \\
20.5\end{array}$ & $\begin{array}{l}12.0 \\
11.0 \\
10.0 \\
10.5 \\
12.5\end{array}$ & $\begin{array}{l}15.0 \\
12.5 \\
13.0 \\
14.0 \\
16.0\end{array}$ & $\begin{array}{l}25.0 \\
22.5 \\
24.0 \\
23.0 \\
24.5\end{array}$ & $\begin{array}{l}18.0 \\
18.5 \\
16.5 \\
20.0 \\
19.5\end{array}$ & $\begin{array}{l}21.0 \\
19.5 \\
19.5 \\
21.0 \\
21.5\end{array}$ \\
\hline $\begin{array}{l}16 \\
17 \\
18 \\
19 \\
20\end{array}$ & $\begin{array}{l}--- \\
--- \\
--- \\
--- \\
---\end{array}$ & $\begin{array}{l}--- \\
--- \\
--- \\
--\end{array}$ & $\begin{array}{l}--- \\
--- \\
--- \\
--- \\
---\end{array}$ & $\begin{array}{l}--- \\
--- \\
--- \\
---\end{array}$ & $\begin{array}{l}--- \\
--- \\
--- \\
--\end{array}$ & $\begin{array}{l}--- \\
-- \\
--- \\
---\end{array}$ & $\begin{array}{l}21.5 \\
21.5 \\
20.5 \\
24.0 \\
25.5\end{array}$ & $\begin{array}{l}15.0 \\
16.5 \\
15.5 \\
16.5 \\
18.0\end{array}$ & $\begin{array}{l}17.5 \\
18.5 \\
18.0 \\
19.5 \\
21.0\end{array}$ & $\begin{array}{l}27.0 \\
27.5 \\
29.0 \\
26.0 \\
22.0\end{array}$ & $\begin{array}{l}20.0 \\
20.5 \\
22.5 \\
20.5 \\
18.5\end{array}$ & $\begin{array}{l}23.0 \\
24.0 \\
25.5 \\
23.0 \\
20.0\end{array}$ \\
\hline $\begin{array}{l}21 \\
22 \\
23 \\
24 \\
25\end{array}$ & $\begin{array}{l}--- \\
--- \\
--- \\
--- \\
---\end{array}$ & $\begin{array}{l}-. \\
-- \\
-- \\
--\end{array}$ & $\begin{array}{l}--- \\
--- \\
--- \\
---\end{array}$ & $\begin{array}{l}--- \\
--- \\
--- \\
---\end{array}$ & $\begin{array}{l}--- \\
--- \\
--- \\
--- \\
---\end{array}$ & $\begin{array}{l}--- \\
--- \\
--- \\
---\end{array}$ & $\begin{array}{l}24.5 \\
23.0 \\
21.5 \\
19.5 \\
17.0\end{array}$ & $\begin{array}{l}19.0 \\
19.0 \\
17.5 \\
17.0 \\
13.5\end{array}$ & $\begin{array}{l}22.0 \\
21.0 \\
19.5 \\
18.0 \\
15.5\end{array}$ & $\begin{array}{l}20.5 \\
23.5 \\
23.5 \\
25.5 \\
27.0\end{array}$ & $\begin{array}{l}19.0 \\
19.5 \\
20.5 \\
22.0 \\
22.5\end{array}$ & $\begin{array}{l}19.5 \\
21.0 \\
21.5 \\
23.5 \\
24.5\end{array}$ \\
\hline $\begin{array}{l}26 \\
27 \\
28 \\
29 \\
30 \\
31\end{array}$ & $\begin{array}{l}--- \\
--- \\
--- \\
--- \\
--- \\
---\end{array}$ & $\begin{array}{l}--. \\
--- \\
--- \\
-\cdots \\
--.\end{array}$ & $\begin{array}{l}--- \\
-- \\
--- \\
--- \\
---\end{array}$ & $\begin{array}{l}--- \\
--- \\
--- \\
--- \\
---\end{array}$ & $\begin{array}{l}--- \\
--- \\
--- \\
--- \\
--- \\
---\end{array}$ & $\begin{array}{l}--- \\
--- \\
--- \\
--- \\
---\end{array}$ & $\begin{array}{r}15.0 \\
16.5 \\
20.0 \\
22.5 \\
22.5 \\
--\end{array}$ & $\begin{array}{l}14.0 \\
14.0 \\
14.0 \\
15.5 \\
19.0 \\
--\end{array}$ & $\begin{array}{c}14.5 \\
15.0 \\
16.5 \\
18.5 \\
20.5 \\
---\end{array}$ & $\begin{array}{l}30.0 \\
27.5 \\
26.0 \\
25.5 \\
24.0 \\
24.5\end{array}$ & $\begin{array}{l}23.5 \\
24.0 \\
21.5 \\
20.5 \\
20.5 \\
21.0\end{array}$ & $\begin{array}{l}26.0 \\
25.5 \\
23.5 \\
23.0 \\
22.5 \\
23.0\end{array}$ \\
\hline $\mathrm{CH}$ & --- & -. & -.- & -- & --- & --- & -.- & -- & --- & 30.0 & 15.5 & 22.0 \\
\hline
\end{tabular}


WATER TEMPERATURE, DEGREES CELSIUS, WATER YEAR OCTOBER 1996 TO SEPTEMBER 1997

\begin{tabular}{|c|c|c|c|c|c|c|c|c|c|c|c|c|}
\hline \multirow[t]{2}{*}{ DAY } & MAX & MIN & MEAN & MAX & MIN & MEAN & MAX & MIN & MEAN & $\operatorname{MAX}$ & MIN & MEAN \\
\hline & \multicolumn{3}{|c|}{ JUNE } & \multicolumn{3}{|c|}{ JULY } & \multicolumn{3}{|c|}{ AUGUST } & \multicolumn{3}{|c|}{ SEPTEMBER } \\
\hline $\begin{array}{l}1 \\
2 \\
3 \\
4 \\
5\end{array}$ & $\begin{array}{l}25.5 \\
25.0 \\
23.5 \\
24.5 \\
25.0\end{array}$ & $\begin{array}{l}20.5 \\
21.0 \\
20.5 \\
21.0 \\
20.0\end{array}$ & $\begin{array}{l}23.0 \\
23.0 \\
22.5 \\
22.5 \\
22.5\end{array}$ & $\begin{array}{l}31.5 \\
32.0 \\
31.5 \\
29.5 \\
27.0\end{array}$ & $\begin{array}{l}26.5 \\
26.5 \\
27.0 \\
26.0 \\
24.0\end{array}$ & $\begin{array}{l}29.0 \\
29.0 \\
29.0 \\
27.5 \\
25.5\end{array}$ & $\begin{array}{l}30.5 \\
30.5 \\
31.0 \\
30.5 \\
31.5\end{array}$ & $\begin{array}{l}26.0 \\
25.5 \\
25.5 \\
26.0 \\
25.5\end{array}$ & $\begin{array}{l}28.0 \\
28.0 \\
28.0 \\
28.0 \\
28.5\end{array}$ & $\begin{array}{l}32.0 \\
31.5 \\
30.5 \\
26.0 \\
28.0\end{array}$ & $\begin{array}{l}27.0 \\
27.0 \\
26.0 \\
24.5 \\
23.0\end{array}$ & $\begin{array}{l}29.0 \\
29.0 \\
28.5 \\
25.0 \\
25.0\end{array}$ \\
\hline $\begin{array}{r}6 \\
7 \\
8 \\
9 \\
10\end{array}$ & $\begin{array}{l}24.0 \\
24.5 \\
23.0 \\
24.5 \\
26.5\end{array}$ & $\begin{array}{l}20.5 \\
20.5 \\
21.0 \\
13.0 \\
17.5\end{array}$ & $\begin{array}{l}22.5 \\
22.5 \\
22.0 \\
21.5 \\
23.0\end{array}$ & $\begin{array}{l}26.0 \\
26.0 \\
29.5 \\
30.0 \\
31.0\end{array}$ & $\begin{array}{l}24.0 \\
23.5 \\
24.0 \\
26.0 \\
27.0\end{array}$ & $\begin{array}{l}25.0 \\
25.0 \\
26.5 \\
28.0 \\
28.5\end{array}$ & $\begin{array}{l}29.5 \\
27.0 \\
24.5 \\
28.0 \\
29.0\end{array}$ & $\begin{array}{l}26.5 \\
23.0 \\
22.5 \\
21.5 \\
25.0\end{array}$ & $\begin{array}{l}28.0 \\
23.5 \\
23.0 \\
24.5 \\
26.5\end{array}$ & $\begin{array}{l}28.0 \\
28.5 \\
28.5 \\
27.5 \\
---\end{array}$ & $\begin{array}{l}23.5 \\
24.0 \\
25.0 \\
25.0 \\
---\end{array}$ & $\begin{array}{r}25.5 \\
26.0 \\
26.5 \\
26.0 \\
--\end{array}$ \\
\hline $\begin{array}{l}11 \\
12 \\
13 \\
14 \\
15\end{array}$ & $\begin{array}{l}27.0 \\
28.5 \\
28.0 \\
29.5 \\
27.5\end{array}$ & $\begin{array}{l}22.5 \\
24.0 \\
22.0 \\
24.5 \\
25.0\end{array}$ & $\begin{array}{l}25.0 \\
26.0 \\
25.5 \\
26.5 \\
26.0\end{array}$ & $\begin{array}{l}30.5 \\
31.0 \\
31.0 \\
32.0 \\
31.5\end{array}$ & $\begin{array}{l}27.0 \\
26.5 \\
27.0 \\
26.5 \\
27.5\end{array}$ & $\begin{array}{l}28.5 \\
28.5 \\
28.5 \\
29.0 \\
29.5\end{array}$ & $\begin{array}{l}28.0 \\
29.0 \\
29.0 \\
31.5 \\
31.0\end{array}$ & $\begin{array}{l}25.5 \\
26.0 \\
26.5 \\
26.5 \\
26.5\end{array}$ & $\begin{array}{l}26.5 \\
27.5 \\
28.0 \\
28.5 \\
28.5\end{array}$ & $\begin{array}{l}--- \\
--- \\
--- \\
--- \\
---\end{array}$ & $\begin{array}{l}--- \\
--- \\
--- \\
---\end{array}$ & $\begin{array}{l}--- \\
-- \\
-- \\
---\end{array}$ \\
\hline $\begin{array}{l}16 \\
17 \\
18 \\
19 \\
20\end{array}$ & $\begin{array}{l}29.5 \\
29.5 \\
28.0 \\
29.5 \\
30.0\end{array}$ & $\begin{array}{l}25.0 \\
24.5 \\
23.5 \\
23.5 \\
25.5\end{array}$ & $\begin{array}{l}27.0 \\
26.5 \\
26.0 \\
26.5 \\
27.5\end{array}$ & $\begin{array}{l}32.5 \\
32.5 \\
30.5 \\
32.0 \\
31.5\end{array}$ & $\begin{array}{l}26.5 \\
27.5 \\
27.5 \\
27.5 \\
27.0\end{array}$ & $\begin{array}{l}29.0 \\
30.0 \\
29.0 \\
29.5 \\
29.5\end{array}$ & $\begin{array}{l}31.0 \\
30.0 \\
30.5 \\
29.0 \\
31.5\end{array}$ & $\begin{array}{l}27.0 \\
27.0 \\
27.0 \\
26.5 \\
26.5\end{array}$ & $\begin{array}{l}29.0 \\
28.5 \\
28.5 \\
28.0 \\
28.5\end{array}$ & $\begin{array}{l}--- \\
--- \\
--- \\
--- \\
---\end{array}$ & $\begin{array}{l}--- \\
--- \\
--- \\
---\end{array}$ & $\begin{array}{l}-.- \\
--- \\
--- \\
---\end{array}$ \\
\hline $\begin{array}{l}21 \\
22 \\
23 \\
24 \\
25\end{array}$ & $\begin{array}{l}30.0 \\
28.0 \\
27.0 \\
29.5 \\
30.0\end{array}$ & $\begin{array}{l}26.0 \\
25.0 \\
24.0 \\
25.0 \\
25.5\end{array}$ & $\begin{array}{l}27.5 \\
26.5 \\
25.5 \\
27.0 \\
27.5\end{array}$ & $\begin{array}{l}32.5 \\
31.0 \\
31.0 \\
32.5 \\
32.5\end{array}$ & $\begin{array}{l}27.0 \\
26.5 \\
26.5 \\
26.0 \\
28.0\end{array}$ & $\begin{array}{l}29.5 \\
28.5 \\
28.5 \\
29.0 \\
30.0\end{array}$ & $\begin{array}{l}32.0 \\
29.0 \\
29.5 \\
30.0 \\
30.5\end{array}$ & $\begin{array}{l}26.5 \\
25.5 \\
26.0 \\
25.0 \\
25.0\end{array}$ & $\begin{array}{l}29.0 \\
28.0 \\
27.5 \\
27.5 \\
27.5\end{array}$ & $\begin{array}{l}--- \\
--- \\
--- \\
--- \\
---\end{array}$ & $\begin{array}{l}--- \\
-- \\
--- \\
---\end{array}$ & $\begin{array}{l}-\cdot- \\
-- \\
-- \\
---\end{array}$ \\
\hline $\begin{array}{l}26 \\
27 \\
28 \\
29 \\
30 \\
31\end{array}$ & $\begin{array}{r}30.0 \\
30.5 \\
29.5 \\
30.5 \\
30.5 \\
---\end{array}$ & $\begin{array}{l}25.0 \\
26.5 \\
26.5 \\
25.0 \\
25.5 \\
---\end{array}$ & $\begin{array}{r}27.5 \\
28.5 \\
28.0 \\
27.5 \\
28.0 \\
---\end{array}$ & $\begin{array}{l}32.0 \\
33.0 \\
33.0 \\
31.5 \\
30.5 \\
31.0\end{array}$ & $\begin{array}{l}27.5 \\
27.5 \\
28.0 \\
28.0 \\
27.5 \\
26.5\end{array}$ & $\begin{array}{l}30.0 \\
30.0 \\
30.0 \\
29.5 \\
28.5 \\
28.5\end{array}$ & $\begin{array}{l}30.5 \\
30.0 \\
30.5 \\
31.5 \\
31.5 \\
32.0\end{array}$ & $\begin{array}{l}25.0 \\
25.0 \\
25.5 \\
26.0 \\
26.5 \\
26.5\end{array}$ & $\begin{array}{l}27.5 \\
27.5 \\
28.0 \\
28.5 \\
28.5 \\
29.0\end{array}$ & $\begin{array}{l}--- \\
-- \\
-- \\
--- \\
---\end{array}$ & $\begin{array}{l}--- \\
--- \\
-- \\
--- \\
--- \\
--\end{array}$ & $\begin{array}{l}--- \\
--- \\
--- \\
--- \\
---\end{array}$ \\
\hline NTH & 30.5 & 13.0 & 25.4 & 33.0 & 23.5 & 28.6 & 32.0 & 21.5 & 27.6 & -.- & -. & --- \\
\hline
\end{tabular}




\section{SAND CREEK SITE 2, POINT SOURCE FROM WASTEWATER TREATMENT PLANT NEAR ARDMORE, OK}

LOCATION.--Lat $34^{\circ} 12^{\prime} 41^{\prime \prime}$, long $97^{\circ} 05^{\prime} 45^{\prime \prime}$, in SW 1/4 NE 1/4 sec.16, T.4 S., R.2 E., Carter County, Hydrologic Unit 11130303, at City of Ardmore Wastewater Treatment Plant, in effluent reaeration pit, $8 \mathrm{ft}$ above discharge point.

PERIOD OF RECORD.--April 1997 to September 1997 (discontinued).

PERIOD OF DAILY RECORD.--

SPECIFIC CONDUCTANCE: April 1997 to September 1997 (discontinued).

WATER TEMPERATURE: April 1997 to September 1997 (discontinued).

INSTRUMENTATION.--Water-quality monitor since April 1997.

REMARKS.--Interruptions in record were due to malfunction of the recording instruments. Water temperature, specific conductance, $\mathrm{pH}$, alkalinity, and dissolved oxygen were determined in the field. Miscellaneous water-quality samples were collected downstream from discharge point.

EXTREMES FOR CURRENT YEAR (April 1997 to September 1997).--

SPECIFIC CONDUCTANCE: Maximum, 1980 microsiemens, June 28; minimum, 483 microsiemens, May 30.

WATER TEMPERATURE: Maximum, $34.0^{\circ} \mathrm{C}$, Sept. 3; minimum, $14.5^{\circ} \mathrm{C}$, Apr. 12.

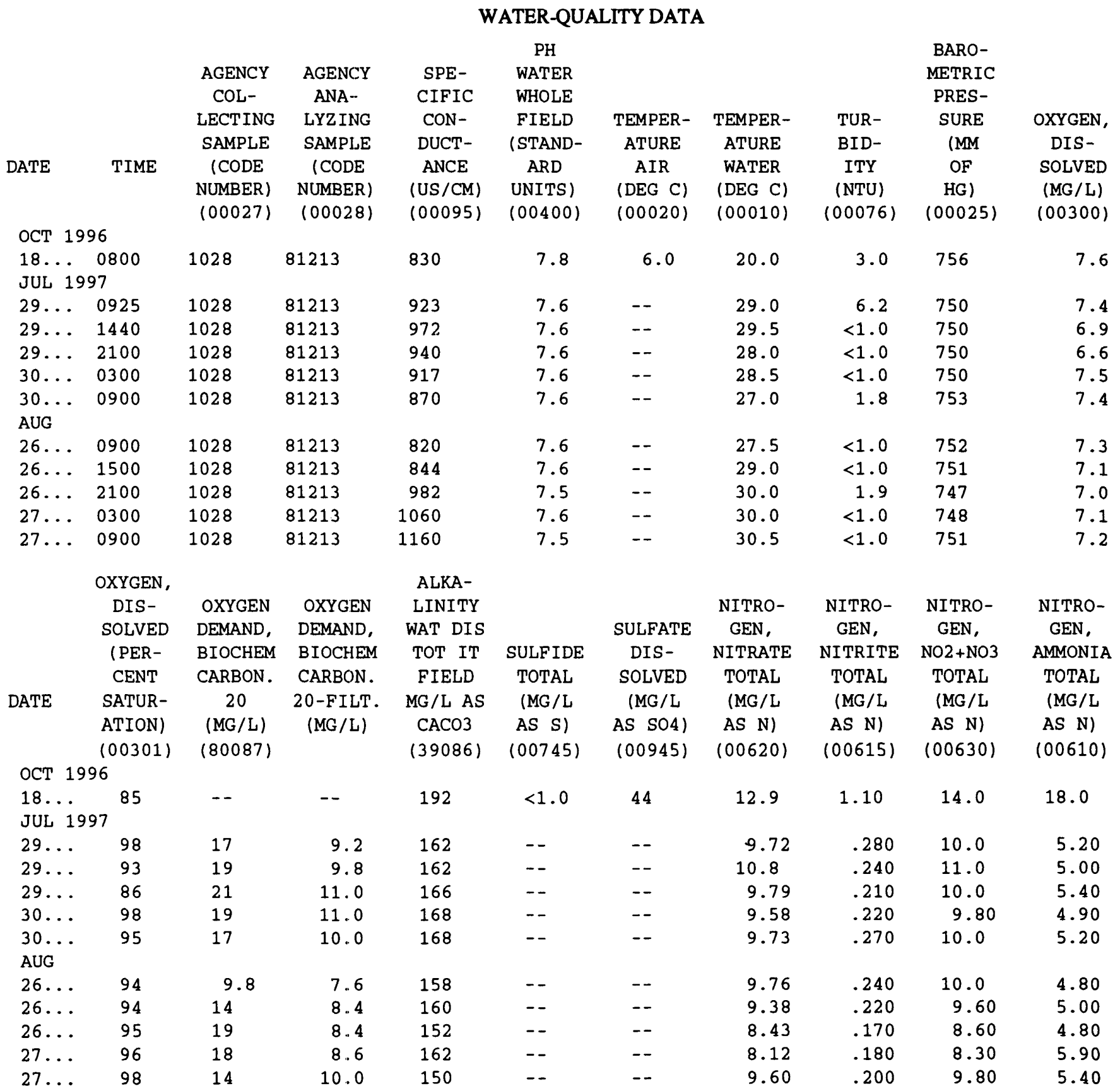


WATER-QUALITY DATA

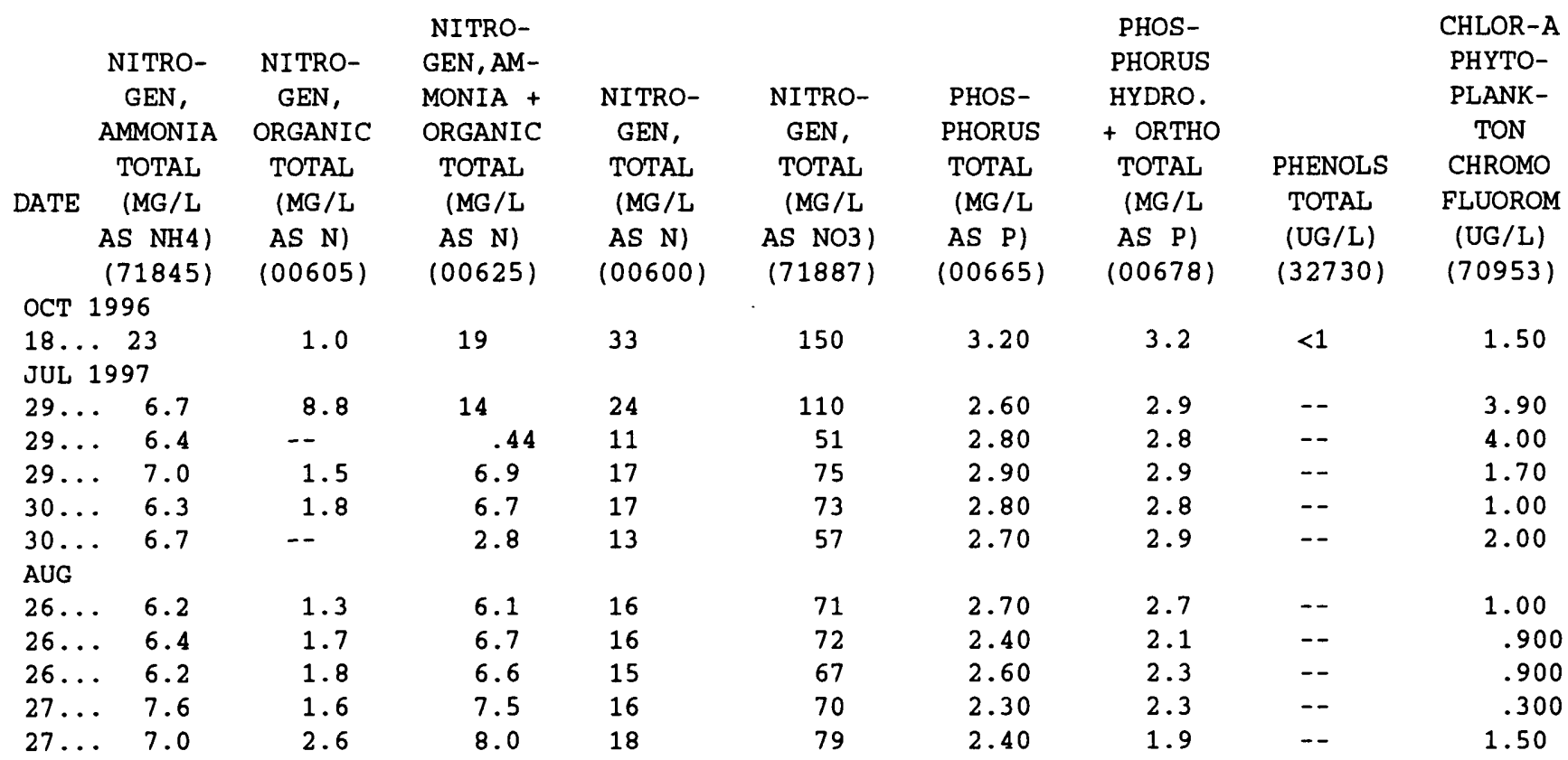

SPECIFIC CONDUCTANCE, US/CM @ 25 DEGREES CELSIUS, WATER YEAR OCTOBER 1996 TO SEPTEMBER 1997

\begin{tabular}{|c|c|c|c|c|c|c|c|c|c|c|c|c|}
\hline \multirow[t]{2}{*}{ DAY } & MAX & MIN & MEAN & MAX & MIN & MEAN & MAX & MIN & MEAN & MAX & MIN & MEAN \\
\hline & \multicolumn{3}{|c|}{ FEBRUARY } & \multicolumn{3}{|c|}{ MARCH } & \multicolumn{3}{|c|}{ APRIL } & \multicolumn{3}{|c|}{ MAY } \\
\hline 1 & --- & --- & ... & --- & -- & -- & -- & --- & --- & 902 & 870 & 889 \\
\hline 2 & -- & -.. & -- & -.- & -.- & -- & -.. & -.- & --- & 912 & 869 & 892 \\
\hline 3 & -.- & $\ldots$ & --- & -.. & -.- & -- & -- &.-- & --- & 901 & 854 & 879 \\
\hline 4 & -- & -.. & -- & -- & -.- & --- & --- & --- & -- & 889 & 824 & 867 \\
\hline 5 & -- & --- & -- & --- & --- & --- & -- & --- & --- & --- & $\cdots$ & -- \\
\hline 6 & -.. & --- & -.. & --- & -. & --- & --- & --- & --- & --- & -- & -- \\
\hline 7 & -- & --- & -.. & -- & -.- & --- &.-- & $\ldots$ & --- & --- & -- & -- \\
\hline 8 & -- & --- & --- & --- & -- & --- & --- & --- & -- & -- & -- & -- \\
\hline 9 & -- &.-- & -- & -- & -- & -- & --- & --- & --- & -- & --- & -- \\
\hline 10 & -- & -- & --- & $\cdots$ & --- & -- & --- & --- & --- & -- & --- & $\cdots$ \\
\hline 11 & -.- & -.- & -.. & --. & -.. & -.. & -.. & --- & ..- & -.- & -.- & $\ldots$ \\
\hline 12 & -- & -.. & --- & --- & -.- & -.- & 746 & 592 & 659 & --- & --- & -.. \\
\hline 13 & --- & --- & --- & --- & --- & --- & 844 & 730 & 795 & --- & --- & -- \\
\hline 14 & --- & $\cdots$ & --- & $\cdots$ & --- & -- & 859 & 817 & 838 & --- & $\cdots$ & -- \\
\hline 15 & -- & --- & -- & --- & -- & --- & 870 & 837 & 858 & -- & -- & -- \\
\hline 16 & -.- & -.. & -- & -.. & -- & -- & 877 & 804 & 865 & 1200 & 905 & 1080 \\
\hline $\begin{array}{l}17 \\
\end{array}$ & -. & --- & --- & --- & ... & -.. & 983 & 847 & 885 & 913 & 849 & 871 \\
\hline 18 & -- & --- & --- & -- & -- & --- & 1030 & 969 & 1000 & 895 & 795 & 841 \\
\hline 19 & -- & --- & --- & --- & --- & --- & 1160 & 996 & 1060 & 837 & 644 & 773 \\
\hline 20 & --- & -- & --- & $\cdots$ & -- & -- & 1250 & 1040 & 1100 & 759 & 621 & 684 \\
\hline 21 & --- & --- & -- & -- & -- & -- & 1420 & 1230 & 1340 & 1000 & 755 & 864 \\
\hline 22 & -- & -- & -- & --- & --- & --- & 1580 & 1320 & 1470 & 1170 & 1000 & 1100 \\
\hline 23 & -- & -- & -- & --- & --- & -- & 1640 & 1480 & 1550 & 1150 & 1010 & 1080 \\
\hline 24 & -- & --- & -- & $\ldots$ & -- & -- & 1560 & 1390 & 1490 & 1320 & 1120 & 1220 \\
\hline 25 & --- & --- & -- & -- & -- & -- & 1650 & 1070 & 1460 & 1360 & 1170 & 1280 \\
\hline 26 & --- & --- & -- & --- & -- & --- & 1170 & 896 & 1030 & 1380 & 1160 & 1250 \\
\hline 27 & --- & -- & $\cdots$ & --- & -- & --- & 1100 & 987 & 1030 & 1480 & 1200 & 1340 \\
\hline 28 & $\cdots$ & --- & --- & $\cdots$ & --- & -. & 1080 & 801 & 889 & 1360 & 1110 & 1280 \\
\hline 29 & -- & --- & -- & --- & -- & -- & 915 & 830 & 868 & 1450 & 1290 & 1350 \\
\hline 30 & --- & -- & --. & --- & --- & --- & 891 & 866 & 877 & 1340 & 483 & 871 \\
\hline 31 & -- & --- & --- & -.- & -.- & -.- & -- & - & -- & 826 & 579 & 704 \\
\hline
\end{tabular}

MONTH 
07330618 SAND CREEK SITE 2, POINT SOURCE FROM WASTEWATER TREATMENT PLANT NEAR ARDMORE, OK-Continued

SPECIFIC CONDUCTANCE, US/CM @ 25 DEGREES CELSIUS, WATER YEAR OCTOBER 1996 TO SEPTEMBER 1997

\begin{tabular}{|c|c|c|c|c|c|c|c|c|c|c|c|c|}
\hline \multirow[t]{2}{*}{ DAY } & MAX & MIN & MEAN & MAX & MIN & MEAN & MAX & MIN & MEAN & MAX & MIN & MEAN \\
\hline & \multicolumn{3}{|c|}{ JUNE } & \multicolumn{3}{|c|}{ JULY } & \multicolumn{3}{|c|}{ AUGUST } & \multicolumn{3}{|c|}{ SEPTEMBER } \\
\hline $\begin{array}{l}1 \\
2 \\
3 \\
4 \\
5\end{array}$ & $\begin{array}{l}1110 \\
1310 \\
1430 \\
1510 \\
1420\end{array}$ & $\begin{array}{r}819 \\
1110 \\
1240 \\
1310 \\
1260\end{array}$ & $\begin{array}{r}859 \\
1240 \\
1330 \\
1410 \\
1340\end{array}$ & $\begin{array}{l}1540 \\
1400 \\
1450 \\
1160 \\
1320\end{array}$ & $\begin{array}{r}1300 \\
1230 \\
1160 \\
920 \\
1080\end{array}$ & $\begin{array}{l}1450 \\
1320 \\
1320 \\
1060 \\
1200\end{array}$ & $\begin{array}{r}896 \\
912 \\
978 \\
1330 \\
1600\end{array}$ & $\begin{array}{r}807 \\
793 \\
856 \\
872 \\
1280\end{array}$ & $\begin{array}{r}857 \\
869 \\
913 \\
1050 \\
1480\end{array}$ & $\begin{array}{l}1430 \\
1310 \\
1440 \\
1210 \\
1280\end{array}$ & $\begin{array}{l}1210 \\
1160 \\
1180 \\
1030 \\
1010\end{array}$ & $\begin{array}{l}1330 \\
1220 \\
1290 \\
1110 \\
1160\end{array}$ \\
\hline $\begin{array}{r}6 \\
7 \\
8 \\
9 \\
10\end{array}$ & $\begin{array}{l}1870 \\
1700 \\
1570 \\
1460 \\
1290\end{array}$ & $\begin{array}{r}1260 \\
1530 \\
1360 \\
1290 \\
679\end{array}$ & $\begin{array}{r}1570 \\
1620 \\
1490 \\
1380 \\
873\end{array}$ & $\begin{array}{l}1370 \\
1610 \\
1790 \\
1730 \\
1530\end{array}$ & $\begin{array}{l}1130 \\
1240 \\
1400 \\
1400 \\
1260\end{array}$ & $\begin{array}{l}1250 \\
1440 \\
1600 \\
1610 \\
1410\end{array}$ & $\begin{array}{r}1410 \\
995 \\
1280 \\
1110 \\
990\end{array}$ & $\begin{array}{l}952 \\
816 \\
968 \\
936 \\
845\end{array}$ & $\begin{array}{r}1160 \\
910 \\
1120 \\
1050 \\
903\end{array}$ & $\begin{array}{c}1260 \\
1240 \\
1270 \\
1220 \\
\ldots\end{array}$ & $\begin{array}{c}1030 \\
1060 \\
1040 \\
1090 \\
---\end{array}$ & $\begin{array}{r}1160 \\
1140 \\
1170 \\
1150 \\
---\end{array}$ \\
\hline $\begin{array}{l}11 \\
12 \\
13 \\
14 \\
15\end{array}$ & $\begin{array}{l}1090 \\
1260 \\
1290 \\
1360 \\
1560\end{array}$ & $\begin{array}{r}908 \\
1090 \\
923 \\
1030 \\
1320\end{array}$ & $\begin{array}{r}999 \\
1170 \\
1120 \\
1230 \\
1450\end{array}$ & $\begin{array}{r}1320 \\
979 \\
960 \\
787 \\
803\end{array}$ & $\begin{array}{l}825 \\
832 \\
734 \\
712 \\
714\end{array}$ & $\begin{array}{l}943 \\
893 \\
835 \\
754 \\
763\end{array}$ & $\begin{array}{r}1140 \\
1260 \\
1090 \\
1300 \\
973\end{array}$ & $\begin{array}{l}940 \\
972 \\
731 \\
973 \\
893\end{array}$ & $\begin{array}{r}1040 \\
1110 \\
874 \\
1180 \\
937\end{array}$ & $\begin{array}{l}--- \\
--- \\
--- \\
--- \\
---\end{array}$ & $\begin{array}{l}--- \\
--- \\
--- \\
--- \\
---\end{array}$ & $\begin{array}{l}-\cdots \\
--- \\
--- \\
-\cdots \\
--\end{array}$ \\
\hline $\begin{array}{l}16 \\
17 \\
18 \\
19 \\
20\end{array}$ & $\begin{array}{l}1590 \\
1380 \\
1630 \\
1650 \\
1770\end{array}$ & $\begin{array}{l}1190 \\
1200 \\
1260 \\
1490 \\
1490\end{array}$ & $\begin{array}{l}1420 \\
1300 \\
1410 \\
1580 \\
1590\end{array}$ & $\begin{array}{r}799 \\
860 \\
855 \\
935 \\
1080\end{array}$ & $\begin{array}{l}710 \\
741 \\
787 \\
740 \\
894\end{array}$ & $\begin{array}{r}760 \\
793 \\
828 \\
809 \\
1000\end{array}$ & $\begin{array}{l}956 \\
848 \\
787 \\
831 \\
795\end{array}$ & $\begin{array}{l}823 \\
744 \\
682 \\
682 \\
711\end{array}$ & $\begin{array}{l}911 \\
781 \\
738 \\
760 \\
752\end{array}$ & $\begin{array}{l}--- \\
--- \\
--- \\
--- \\
---\end{array}$ & $\begin{array}{l}--- \\
--- \\
--- \\
--- \\
---\end{array}$ & $\begin{array}{l}-\cdots \\
-\cdots \\
-\cdots- \\
--- \\
---\end{array}$ \\
\hline $\begin{array}{l}21 \\
22 \\
23 \\
24 \\
25\end{array}$ & $\begin{array}{l}1700 \\
1550 \\
1380 \\
1210 \\
1660\end{array}$ & $\begin{array}{r}1450 \\
1340 \\
914 \\
902 \\
1140\end{array}$ & $\begin{array}{l}1590 \\
1450 \\
1190 \\
1080 \\
1430\end{array}$ & $\begin{array}{r}1030 \\
961 \\
1090 \\
1020 \\
1090\end{array}$ & $\begin{array}{l}911 \\
759 \\
811 \\
903 \\
934\end{array}$ & $\begin{array}{r}962 \\
846 \\
960 \\
971 \\
1010\end{array}$ & $\begin{array}{l}909 \\
960 \\
805 \\
811 \\
775\end{array}$ & $\begin{array}{l}690 \\
717 \\
714 \\
748 \\
711\end{array}$ & $\begin{array}{l}770 \\
840 \\
749 \\
779 \\
743\end{array}$ & $\begin{array}{l}--- \\
--- \\
--- \\
--- \\
---\end{array}$ & $\begin{array}{l}--- \\
--- \\
--- \\
--- \\
---\end{array}$ & $\begin{array}{l}--- \\
--- \\
--- \\
--- \\
---\end{array}$ \\
\hline $\begin{array}{l}26 \\
27 \\
28 \\
29 \\
30 \\
31\end{array}$ & $\begin{array}{c}1820 \\
1930 \\
1980 \\
1770 \\
1730 \\
---\end{array}$ & $\begin{array}{r}872 \\
1650 \\
1670 \\
1430 \\
1450 \\
---\end{array}$ & $\begin{array}{c}1360 \\
1790 \\
1800 \\
1650 \\
1570 \\
---\end{array}$ & $\begin{array}{r}1090 \\
1050 \\
934 \\
926 \\
905 \\
925\end{array}$ & $\begin{array}{l}964 \\
834 \\
830 \\
776 \\
802 \\
793\end{array}$ & $\begin{array}{r}1020 \\
941 \\
894 \\
882 \\
848 \\
857\end{array}$ & $\begin{array}{l}1000 \\
1430 \\
1510 \\
1580 \\
1390 \\
1600\end{array}$ & $\begin{array}{r}731 \\
974 \\
1350 \\
1310 \\
1270 \\
1270\end{array}$ & $\begin{array}{r}834 \\
1250 \\
1420 \\
1460 \\
1330 \\
1440\end{array}$ & $\begin{array}{l}--- \\
--- \\
--- \\
--- \\
--- \\
---\end{array}$ & $\begin{array}{l}--- \\
--- \\
--- \\
--- \\
--- \\
---\end{array}$ & $\begin{array}{l}--- \\
-- \\
-- \\
-- \\
-\cdots \\
---\end{array}$ \\
\hline $\mathrm{NTH}$ & 1980 & 679 & 1380 & 1790 & 710 & 1040 & 1600 & 682 & 1000 & --- & -- & -- \\
\hline
\end{tabular}


07330618 SAND CREEK SITE 2, POINT SOURCE FROM WASTEWATER TREATMENT PLANT NEAR ARDMORE, OK-Continued

WATER TEMPERATURE, DEGREES CELSIUS, WATER YEAR OCTOBER 1996 TO SEPTEMBER 1997

\begin{tabular}{|c|c|c|c|c|c|c|c|c|c|c|c|c|}
\hline \multirow[t]{2}{*}{ DAY } & MAX & MIN & MEAN & MAX & MIN & MEAN & MAX & MIN & MEAN & MAX & MIN & MEAN \\
\hline & \multicolumn{3}{|c|}{ FEBRUARY } & \multicolumn{3}{|c|}{ MARCH } & \multicolumn{3}{|c|}{ APRIL } & \multicolumn{3}{|c|}{ MAY } \\
\hline $\begin{array}{l}1 \\
2 \\
3 \\
4 \\
5\end{array}$ & $\begin{array}{l}--- \\
--- \\
--- \\
--- \\
---\end{array}$ & $\begin{array}{l}--- \\
--- \\
--- \\
--- \\
---\end{array}$ & $\begin{array}{l}--- \\
--- \\
--- \\
--- \\
---\end{array}$ & $\begin{array}{l}--- \\
--- \\
--- \\
--- \\
---\end{array}$ & $\begin{array}{l}--- \\
--- \\
--- \\
--- \\
---\end{array}$ & $\begin{array}{l}--- \\
-- \\
--- \\
--- \\
---\end{array}$ & $\begin{array}{l}--- \\
--- \\
--- \\
--- \\
---\end{array}$ & $\begin{array}{l}--- \\
--- \\
-- \\
-- \\
--\end{array}$ & $\begin{array}{l}-- \\
--- \\
--- \\
--- \\
---\end{array}$ & $\begin{array}{l}22.5 \\
21.0 \\
20.0 \\
19.5 \\
---\end{array}$ & $\begin{array}{l}17.5 \\
18.5 \\
18.0 \\
18.0 \\
--\end{array}$ & $\begin{array}{l}18.5 \\
19.5 \\
19.0 \\
18.5 \\
---\end{array}$ \\
\hline $\begin{array}{r}6 \\
7 \\
8 \\
9 \\
10\end{array}$ & $\begin{array}{l}--- \\
--- \\
--- \\
---\end{array}$ & $\begin{array}{l}--- \\
--- \\
--- \\
--- \\
---\end{array}$ & $\begin{array}{l}--- \\
--- \\
--- \\
--- \\
---\end{array}$ & $\begin{array}{l}--- \\
--- \\
--- \\
--- \\
---\end{array}$ & $\begin{array}{l}--- \\
--- \\
--- \\
--- \\
---\end{array}$ & $\begin{array}{l}--- \\
--- \\
--- \\
--- \\
---\end{array}$ & $\begin{array}{l}--- \\
--- \\
--- \\
--- \\
---\end{array}$ & $\begin{array}{l}--- \\
--- \\
--- \\
--- \\
---\end{array}$ & $\begin{array}{l}--- \\
--- \\
--- \\
--- \\
---\end{array}$ & $\begin{array}{l}--- \\
--- \\
--- \\
--- \\
---\end{array}$ & $\begin{array}{l}-- \\
-- \\
-- \\
-- \\
--\end{array}$ & $\begin{array}{l}--- \\
--- \\
--- \\
--- \\
--\end{array}$ \\
\hline $\begin{array}{l}11 \\
12 \\
13 \\
14 \\
15\end{array}$ & $\begin{array}{l}--- \\
-- \\
--- \\
---\end{array}$ & $\begin{array}{l}--- \\
--- \\
--- \\
---\end{array}$ & $\begin{array}{l}--- \\
--- \\
--- \\
--- \\
---\end{array}$ & $\begin{array}{l}--- \\
--- \\
--- \\
--- \\
---\end{array}$ & $\begin{array}{l}--- \\
--- \\
--- \\
--- \\
---\end{array}$ & $\begin{array}{l}--- \\
--- \\
--- \\
--- \\
---\end{array}$ & $\begin{array}{l}-- \\
16.0 \\
17.0 \\
17.5 \\
18.0\end{array}$ & $\begin{array}{l}-- \\
14.5 \\
15.0 \\
15.5 \\
16.0\end{array}$ & $\begin{array}{l}-- \\
15.5 \\
16.0 \\
16.5 \\
17.0\end{array}$ & $\begin{array}{l}--- \\
--- \\
--- \\
--- \\
---\end{array}$ & $\begin{array}{l}--- \\
--- \\
--- \\
--- \\
---\end{array}$ & $\begin{array}{l}--- \\
--- \\
--- \\
--- \\
---\end{array}$ \\
\hline $\begin{array}{l}16 \\
17 \\
18 \\
19 \\
20\end{array}$ & $\begin{array}{l}--- \\
--- \\
--- \\
--- \\
---\end{array}$ & $\begin{array}{l}--- \\
--- \\
--- \\
---\end{array}$ & $\begin{array}{l}--- \\
--- \\
--- \\
--- \\
---\end{array}$ & $\begin{array}{l}--- \\
--- \\
--- \\
--- \\
---\end{array}$ & $\begin{array}{l}--- \\
--- \\
--- \\
--- \\
---\end{array}$ & $\begin{array}{l}--- \\
--- \\
--- \\
-- \\
---\end{array}$ & $\begin{array}{l}18.5 \\
20.0 \\
19.0 \\
21.0 \\
21.5\end{array}$ & $\begin{array}{l}16.5 \\
17.0 \\
18.0 \\
18.0 \\
18.5\end{array}$ & $\begin{array}{l}17.5 \\
17.5 \\
18.5 \\
19.0 \\
19.5\end{array}$ & $\begin{array}{l}25.5 \\
23.0 \\
23.0 \\
21.5 \\
21.0\end{array}$ & $\begin{array}{l}21.0 \\
21.0 \\
20.5 \\
20.5 \\
20.5\end{array}$ & $\begin{array}{l}22.5 \\
21.5 \\
21.5 \\
21.0 \\
21.0\end{array}$ \\
\hline $\begin{array}{l}21 \\
22 \\
23 \\
24 \\
25\end{array}$ & $\begin{array}{l}--- \\
--- \\
--- \\
--- \\
--\end{array}$ & $\begin{array}{l}--- \\
--- \\
--- \\
--- \\
---\end{array}$ & $\begin{array}{l}--- \\
--- \\
--- \\
--- \\
---\end{array}$ & $\begin{array}{l}--- \\
--- \\
--- \\
--- \\
---\end{array}$ & $\begin{array}{l}--- \\
--- \\
--- \\
--- \\
---\end{array}$ & $\begin{array}{l}--- \\
--- \\
--- \\
--- \\
---\end{array}$ & $\begin{array}{l}23.0 \\
22.5 \\
23.0 \\
22.0 \\
21.0\end{array}$ & $\begin{array}{l}20.5 \\
21.0 \\
21.5 \\
21.0 \\
19.5\end{array}$ & $\begin{array}{l}21.5 \\
21.5 \\
22.0 \\
21.5 \\
20.5\end{array}$ & $\begin{array}{l}22.5 \\
26.0 \\
24.5 \\
27.0 \\
27.0\end{array}$ & $\begin{array}{l}21.0 \\
22.5 \\
23.0 \\
24.0 \\
25.0\end{array}$ & $\begin{array}{l}21.5 \\
24.0 \\
23.5 \\
25.5 \\
25.5\end{array}$ \\
\hline $\begin{array}{l}26 \\
27 \\
28 \\
29 \\
30 \\
31\end{array}$ & $\begin{array}{l}--- \\
--- \\
--- \\
--- \\
--- \\
---\end{array}$ & $\begin{array}{l}--- \\
--- \\
--- \\
--- \\
--- \\
---\end{array}$ & $\begin{array}{l}--- \\
--- \\
--- \\
--- \\
--- \\
---\end{array}$ & $\begin{array}{l}--- \\
--- \\
--- \\
--- \\
--- \\
---\end{array}$ & $\begin{array}{l}--- \\
--- \\
--- \\
--- \\
--- \\
---\end{array}$ & $\begin{array}{l}--- \\
--- \\
--- \\
--- \\
--- \\
---\end{array}$ & $\begin{array}{r}19.5 \\
19.5 \\
19.5 \\
19.5 \\
19.5 \\
---\end{array}$ & $\begin{array}{l}19.0 \\
19.0 \\
18.0 \\
17.5 \\
18.0 \\
--\end{array}$ & $\begin{array}{l}19.0 \\
19.5 \\
18.5 \\
18.5 \\
18.5 \\
--\end{array}$ & $\begin{array}{l}26.5 \\
27.0 \\
25.5 \\
27.0 \\
25.0 \\
23.0\end{array}$ & $\begin{array}{l}24.5 \\
25.0 \\
23.5 \\
24.5 \\
21.5 \\
21.5\end{array}$ & $\begin{array}{l}25.5 \\
25.5 \\
25.0 \\
25.0 \\
22.5 \\
22.0\end{array}$ \\
\hline
\end{tabular}

MONTH 

Continued

WATER TEMPERATURE, DEGREES CELSIUS, WATER YEAR OCTOBER 1996 TO SEPTEMBER 1997

\begin{tabular}{|c|c|c|c|c|c|c|c|c|c|c|c|c|}
\hline \multirow[t]{2}{*}{ DAY } & MAX & MIN & MEAN & MAX & MIN & MEAN & MAX & MIN & MEAN & MAX & MIN & MEAN \\
\hline & \multicolumn{3}{|c|}{ JUNE } & \multicolumn{3}{|c|}{ JULY } & \multicolumn{3}{|c|}{ AUGUST } & \multicolumn{3}{|c|}{ SEPTEMBER } \\
\hline $\begin{array}{l}1 \\
2 \\
3 \\
4 \\
5\end{array}$ & $\begin{array}{l}23.5 \\
26.5 \\
27.5 \\
28.0 \\
27.5\end{array}$ & $\begin{array}{l}21.5 \\
23.5 \\
25.0 \\
26.0 \\
26.0\end{array}$ & $\begin{array}{l}22.5 \\
25.0 \\
26.0 \\
27.0 \\
26.5\end{array}$ & $\begin{array}{l}31.0 \\
31.0 \\
31.5 \\
30.0 \\
31.0\end{array}$ & $\begin{array}{l}29.5 \\
29.0 \\
29.5 \\
27.5 \\
29.0\end{array}$ & $\begin{array}{l}30.0 \\
30.0 \\
30.5 \\
28.5 \\
29.5\end{array}$ & $\begin{array}{l}29.0 \\
29.5 \\
29.5 \\
30.5 \\
33.5\end{array}$ & $\begin{array}{l}28.0 \\
28.0 \\
28.0 \\
28.0 \\
30.5\end{array}$ & $\begin{array}{l}28.5 \\
28.5 \\
28.5 \\
29.0 \\
32.0\end{array}$ & $\begin{array}{l}33.5 \\
33.5 \\
34.0 \\
32.0 \\
32.5\end{array}$ & $\begin{array}{l}31.5 \\
31.5 \\
32.0 \\
31.0 \\
31.0\end{array}$ & $\begin{array}{l}32.5 \\
32.5 \\
33.0 \\
31.5 \\
31.5\end{array}$ \\
\hline $\begin{array}{r}6 \\
7 \\
8 \\
9 \\
10\end{array}$ & $\begin{array}{l}27.5 \\
27.0 \\
26.0 \\
27.0 \\
25.5\end{array}$ & $\begin{array}{l}25.5 \\
25.0 \\
25.0 \\
25.5 \\
22.5\end{array}$ & $\begin{array}{l}26.5 \\
26.0 \\
25.5 \\
26.0 \\
24.0\end{array}$ & $\begin{array}{l}30.5 \\
30.5 \\
31.5 \\
31.5 \\
32.0\end{array}$ & $\begin{array}{l}28.5 \\
29.0 \\
29.5 \\
29.5 \\
30.0\end{array}$ & $\begin{array}{l}29.5 \\
29.5 \\
30.0 \\
30.5 \\
30.5\end{array}$ & $\begin{array}{l}32.5 \\
29.0 \\
30.0 \\
29.0 \\
29.0\end{array}$ & $\begin{array}{l}29.0 \\
27.5 \\
28.5 \\
28.0 \\
28.0\end{array}$ & $\begin{array}{l}30.5 \\
28.0 \\
29.0 \\
28.5 \\
28.5\end{array}$ & $\begin{array}{l}32.5 \\
32.5 \\
32.0 \\
31.5 \\
31.5\end{array}$ & $\begin{array}{l}30.5 \\
30.5 \\
30.5 \\
30.5 \\
30.5\end{array}$ & $\begin{array}{l}31.5 \\
31.0 \\
31.0 \\
31.0 \\
31.0\end{array}$ \\
\hline $\begin{array}{l}11 \\
12 \\
13 \\
14 \\
15\end{array}$ & $\begin{array}{l}26.0 \\
27.5 \\
26.5 \\
27.5 \\
28.5\end{array}$ & $\begin{array}{l}24.0 \\
25.0 \\
25.5 \\
26.0 \\
26.5\end{array}$ & $\begin{array}{l}25.0 \\
26.0 \\
26.0 \\
26.5 \\
27.5\end{array}$ & $\begin{array}{l}30.5 \\
28.0 \\
27.5 \\
27.5 \\
27.5\end{array}$ & $\begin{array}{l}26.5 \\
26.5 \\
26.0 \\
26.0 \\
26.5\end{array}$ & $\begin{array}{l}28.0 \\
27.0 \\
27.0 \\
27.0 \\
27.0\end{array}$ & $\begin{array}{l}30.5 \\
31.5 \\
30.0 \\
33.0 \\
30.0\end{array}$ & $\begin{array}{l}29.0 \\
30.0 \\
28.5 \\
29.5 \\
26.0\end{array}$ & $\begin{array}{l}29.5 \\
30.5 \\
29.0 \\
30.5 \\
28.5\end{array}$ & $\begin{array}{l}--- \\
--- \\
--- \\
--- \\
---\end{array}$ & $\begin{array}{l}--- \\
--- \\
--- \\
--- \\
---\end{array}$ & $\begin{array}{l}--- \\
--- \\
--- \\
--- \\
---\end{array}$ \\
\hline $\begin{array}{l}16 \\
17 \\
18 \\
19 \\
20\end{array}$ & $\begin{array}{l}29.0 \\
28.5 \\
29.5 \\
31.0 \\
29.5\end{array}$ & $\begin{array}{l}26.0 \\
26.0 \\
27.0 \\
27.5 \\
28.0\end{array}$ & $\begin{array}{l}27.5 \\
27.0 \\
28.0 \\
28.5 \\
28.5\end{array}$ & $\begin{array}{l}27.5 \\
28.0 \\
27.5 \\
28.0 \\
29.0\end{array}$ & $\begin{array}{l}26.0 \\
26.5 \\
26.5 \\
27.0 \\
27.5\end{array}$ & $\begin{array}{l}27.0 \\
27.0 \\
27.0 \\
27.5 \\
28.0\end{array}$ & $\begin{array}{l}29.5 \\
29.0 \\
29.0 \\
29.0 \\
30.0\end{array}$ & $\begin{array}{l}28.0 \\
27.5 \\
28.0 \\
28.0 \\
28.0\end{array}$ & $\begin{array}{l}28.5 \\
28.0 \\
28.5 \\
28.5 \\
29.0\end{array}$ & $\begin{array}{l}--- \\
--- \\
--- \\
--- \\
---\end{array}$ & $\begin{array}{l}--- \\
--- \\
--- \\
--- \\
---\end{array}$ & $\begin{array}{l}--- \\
--- \\
--- \\
--- \\
---\end{array}$ \\
\hline $\begin{array}{l}21 \\
22 \\
23 \\
24 \\
25\end{array}$ & $\begin{array}{l}29.5 \\
29.0 \\
28.5 \\
28.5 \\
29.5\end{array}$ & $\begin{array}{l}27.5 \\
27.5 \\
26.0 \\
26.0 \\
26.5\end{array}$ & $\begin{array}{l}28.5 \\
28.0 \\
27.5 \\
27.5 \\
28.5\end{array}$ & $\begin{array}{l}29.5 \\
28.5 \\
29.5 \\
29.5 \\
30.0\end{array}$ & $\begin{array}{l}28.0 \\
27.5 \\
27.5 \\
28.0 \\
28.5\end{array}$ & $\begin{array}{l}28.5 \\
28.0 \\
28.5 \\
29.0 \\
29.0\end{array}$ & $\begin{array}{l}30.0 \\
29.0 \\
29.0 \\
29.0 \\
28.5\end{array}$ & $\begin{array}{l}28.0 \\
28.0 \\
27.5 \\
27.5 \\
27.5\end{array}$ & $\begin{array}{l}28.5 \\
28.5 \\
28.0 \\
28.0 \\
28.0\end{array}$ & $\begin{array}{l}--- \\
--- \\
--- \\
--- \\
---\end{array}$ & $\begin{array}{l}--- \\
--- \\
--- \\
--- \\
---\end{array}$ & $\begin{array}{l}--- \\
--- \\
--- \\
--- \\
---\end{array}$ \\
\hline $\begin{array}{l}26 \\
27 \\
28 \\
29 \\
30 \\
31\end{array}$ & $\begin{array}{r}29.0 \\
30.5 \\
31.0 \\
31.0 \\
31.5 \\
---\end{array}$ & $\begin{array}{r}25.0 \\
29.0 \\
29.5 \\
29.5 \\
29.5 \\
--\end{array}$ & $\begin{array}{r}27.0 \\
29.5 \\
30.0 \\
30.0 \\
30.5 \\
--\end{array}$ & $\begin{array}{l}30.0 \\
30.0 \\
30.0 \\
30.0 \\
29.5 \\
29.5\end{array}$ & $\begin{array}{l}28.5 \\
28.5 \\
28.5 \\
28.5 \\
28.0 \\
28.0\end{array}$ & $\begin{array}{l}29.0 \\
29.0 \\
29.0 \\
29.0 \\
28.5 \\
28.5\end{array}$ & $\begin{array}{l}30.0 \\
32.5 \\
32.5 \\
33.0 \\
33.0 \\
33.5\end{array}$ & $\begin{array}{l}27.5 \\
30.0 \\
30.5 \\
31.0 \\
31.0 \\
31.5\end{array}$ & $\begin{array}{l}28.5 \\
31.0 \\
31.5 \\
32.0 \\
32.0 \\
32.5\end{array}$ & $\begin{array}{l}--- \\
--- \\
--- \\
--- \\
---\end{array}$ & $\begin{array}{l}--- \\
--- \\
--- \\
--- \\
---\end{array}$ & $\begin{array}{l}--- \\
--- \\
--- \\
--- \\
--- \\
---\end{array}$ \\
\hline $\mathrm{JTH}$ & 31.5 & 21.5 & 27.1 & 32.0 & 26.0 & 28.6 & 33.5 & 26.0 & 29.4 & -- & -- & --- \\
\hline
\end{tabular}




\section{SAND CREEK SITE 3, COMPARATIVE SAMPLE SITE NEAR ARDMORE, OK}

LOCATION.--Lat $34^{\circ} 12^{\prime} 47^{\prime \prime}$, long $97^{\circ} 05^{\prime} 25^{\prime \prime}$, in NE 1/4 NE 1/4 sec.10, T.4 S., R.2 E., Carter County, Hydrologic Unit 11130303, on left bank adjacent to Atchinson, Topeka, and Sante Fe Railroad tracks, $1.0 \mathrm{mi}$ downstream from City of Ardmore Wastewater Treatment Plant, and at mile 4.1.

PERIOD OF RECORD.--October 1996 to August 1997 (discontinued).

REMARKS.--Water temperature, specific conductance, $\mathrm{pH}$, alkalinity, and dissolved oxygen were determined in the field.

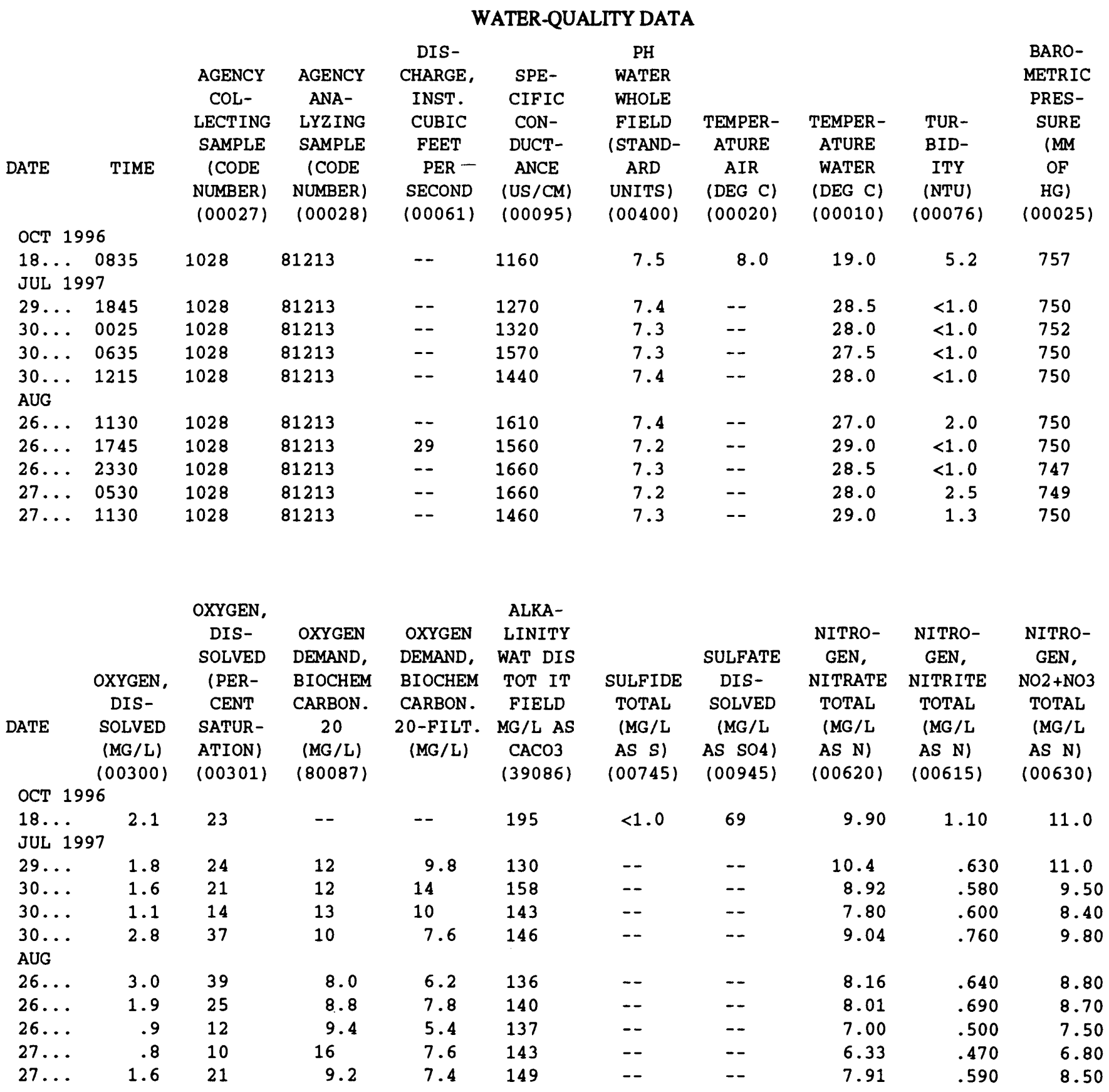




\section{WATER-QUALITY DATA}

\begin{tabular}{|c|c|c|c|c|c|c|c|c|c|c|}
\hline A & $\begin{array}{l}\text { NITRO- } \\
\text { GEN, } \\
\text { AMMONIA } \\
\text { TOTAL } \\
\text { (MG/L } \\
\text { AS N) } \\
(00610)\end{array}$ & $\begin{array}{c}\text { NITRO- } \\
\text { GEN, } \\
\text { AMMONIA } \\
\text { TOTAL } \\
\text { (MG/L } \\
\text { AS NH4) } \\
(71845)\end{array}$ & $\begin{array}{l}\text { NITRO- } \\
\text { GEN, } \\
\text { ORGANIC } \\
\text { TOTAL } \\
\text { (MG/L } \\
\text { AS N) } \\
(00605)\end{array}$ & $\begin{array}{c}\text { NITRO- } \\
\text { GEN, AM- } \\
\text { MONIA + } \\
\text { ORGANIC } \\
\text { TOTAL } \\
\text { (MG/L } \\
\text { AS N) } \\
(00625)\end{array}$ & $\begin{array}{l}\text { NITRO- } \\
\text { GEN, } \\
\text { TOTAL } \\
\text { (MG/L } \\
\text { AS N) } \\
(00600)\end{array}$ & $\begin{array}{c}\text { NITRO- } \\
\text { GEN, } \\
\text { TOTAL } \\
\text { (MG/L } \\
\text { AS NO3) } \\
\text { (71887) }\end{array}$ & $\begin{array}{c}\text { PHOS- } \\
\text { PHORUS } \\
\text { TOTAL } \\
\text { (MG/L } \\
\text { AS P) } \\
(00665)\end{array}$ & $\begin{array}{c}\text { PHOS- } \\
\text { PHORUS } \\
\text { HYDRO. } \\
+ \text { ORTHO } \\
\text { TOTAL } \\
\text { (MG/L } \\
\text { AS P) } \\
(00678)\end{array}$ & $\begin{array}{l}\text { PHENOLS } \\
\text { TOTAL } \\
\text { (UG/L) } \\
(32730)\end{array}$ & $\begin{array}{l}\text { CHLOR-A } \\
\text { PHYTO- } \\
\text { PLANK- } \\
\text { TON } \\
\text { CHROMO } \\
\text { FLUOROM } \\
\text { (UG/L) } \\
(70953)\end{array}$ \\
\hline \multicolumn{11}{|c|}{ OCT 1996} \\
\hline $\begin{array}{l}18 \ldots \\
\text { JUL } 1997\end{array}$ & $7^{16.0}$ & 21 & 3.0 & 19 & 30 & 130 & 3.00 & 3.0 & $<1$ & .200 \\
\hline $29 \ldots$ & 4.40 & 5.7 & .80 & 5.2 & 16 & 72 & 2.50 & 2.7 & -- & 1.90 \\
\hline $30 \ldots$ & 4.30 & 5.5 & .50 & 4.8 & 14 & 63 & 2.70 & 2.6 & -- & 1.10 \\
\hline $30 \ldots$ & 4.20 & 5.4 & .80 & 5.0 & 13 & 59 & 2.40 & 2.6 & -- & 3.70 \\
\hline $30 \ldots$ & 3.90 & 5.0 & 1.6 & 5.5 & 15 & 68 & 2.40 & 2.5 & -- & 3.00 \\
\hline \multicolumn{11}{|l|}{ AUG } \\
\hline $26 \ldots$ & 3.10 & 4.0 & 1.9 & 5.0 & 14 & 61 & 2.20 & 2.2 & -- & 11.0 \\
\hline $26 \ldots$ & 3.40 & 4.4 & 1.4 & 4.8 & 14 & 60 & 2.20 & 2.0 & -- & 8.10 \\
\hline 26. & 3.80 & 4.9 & 1.6 & 5.4 & 13 & 57 & 2.10 & 2.0 & -- & 9.50 \\
\hline $27 \ldots$ & 4.50 & 5.8 & 1.6 & 6.1 & 13 & 57 & 2.00 & 2.0 & -- & 10.0 \\
\hline & 4.60 & .9 & 2.1 & 6.7 & & & 2.20 & 2.1 & -- & 6,30 \\
\hline
\end{tabular}

DATE

JUL 31-AUG 29

JUL 31-AUG 29

JUL 31-AUG 29

$\begin{array}{cc}\text { AGENCY } & \text { AGENCY } \\ \text { COL- } & \text { ANA- } \\ \text { LECTING } & \text { LYZING } \\ \text { SAMPLE } & \text { SAMPLE } \\ \text { (CODE } & \text { (CODE } \\ \text { NUMBER) } & \text { NUMBER) } \\ (00027) & (00028)\end{array}$

1028

.1028

1028
81213

81213

81213

$$
\begin{aligned}
& \text { PERI- } \\
& \text { PHYTON } \\
& \text { BIOMASS } \\
& \text { ASH } \\
& \text { WEIGHT } \\
& \text { G/SQ M } \\
& (00572)
\end{aligned}
$$

\begin{tabular}{|c|c|c|c|c|}
\hline \multirow[b]{2}{*}{ DATE } & \multirow[b]{2}{*}{ TIME } & $\begin{array}{l}\text { AGENCY } \\
\text { COL- } \\
\text { LECTING }\end{array}$ & $\begin{array}{l}\text { AGENCY } \\
\text { ANA- } \\
\text { LYZ ING }\end{array}$ & \\
\hline & & $\begin{array}{c}\text { SAMPLE } \\
\text { (CODE } \\
\text { NUMBER) } \\
(00027)\end{array}$ & $\begin{array}{c}\text { SAMPLE } \\
\text { (CODE } \\
\text { NUMBER) } \\
(00028)\end{array}$ & $\begin{array}{c}\text { PROPANE } \\
\text { TOTAL } \\
\text { (UG/L) } \\
(82358)\end{array}$ \\
\hline \multicolumn{5}{|c|}{ JUL 1997} \\
\hline $17 \ldots$ & 1710 & 1028 & 81213 & $<1.0$ \\
\hline $17 \ldots$ & 1716 & 1028 & 81213 & $<1.0$ \\
\hline $17 \ldots$ & 1724 & 1028 & 81213 & $<1.0$ \\
\hline $17 \ldots$ & 1732 & 1028 & 81213 & 5.6 \\
\hline $17 \ldots$ & 1740 & 1028 & 81213 & 9.1 \\
\hline $17 \ldots$ & 1757 & 1028 & 81213 & 35.0 \\
\hline $17 \ldots$ & 1807 & 1028 & 81213 & 37.0 \\
\hline $17 \ldots$ & 1817 & 1028 & 81213 & 48.0 \\
\hline $17 \ldots$ & 1823 & 1028 & 81213 & 40.0 \\
\hline $17 \ldots$ & 1836 & 1028 & 81213 & 32.0 \\
\hline $17 \ldots$ & 1906 & 1028 & 81213 & 21.0 \\
\hline $17 \ldots$ & 2006 & 1028 & 81213 & 2.8 \\
\hline $17 \ldots$ & 2115 & 1028 & 81213 & $<1.0$ \\
\hline
\end{tabular}

$$
\begin{gathered}
9.02 \\
10.9 \\
7.93
\end{gathered}
$$

$\begin{array}{cc}\text { PERI- } & \text { CHLOR-A } \\ \text { PHYTON } & \text { PERI- } \\ \text { BIOMASS } & \text { PHYTON } \\ \text { TOTAL } & \text { CHROMO- } \\ \text { DRY } & \text { GRAPHIC } \\ \text { WEIGHT } & \text { FLUOROM } \\ \text { G/SQ M } & \text { (MG/M2) } \\ (00573) & (70957) \\ 25.0 & 11000 \\ 33.7 & 14000 \\ 14.7 & 6860\end{array}$


LOCATION.--Lat $34^{\circ} 13^{\prime} 12^{\prime \prime}$, long $97^{\circ} 05^{\prime} 10^{\prime \prime}$, in SW 1/4 SW 1/4 sec.10, T.4 S., R.2 E., Carter County, Hydrologic Unit 11130303, on left bank adjacent to Atchinson, Topeka, and Sante Fe Railroad tracks, 1.3 mi downstream from City of Ardmore Wastewater Treatment Plant, and at mile 3.2.

PERIOD OF RECORD.--October 1996 to August 1997 (discontinued).

\begin{tabular}{|c|c|c|c|c|c|}
\hline & & & WATER-QU & CY DATA & \\
\hline & & & & PERI- & CHLOR-A \\
\hline & AGENCY & AGENCY & PERI - & PHYTON & PERI- \\
\hline & COL- & ANA- & PHYTON & BIOMASS & PHYTON \\
\hline & LECTING & LYZING & BIOMASS & TOTAL & CHROMO- \\
\hline & SAMPLE & SAMPLE & ASH & DRY & GRAPHIC \\
\hline DATE & (CODE & (CODE & WEIGHT & WEIGHT & FLUOROM \\
\hline & NUMBER) & NUMBER) & G/SQ M & $\mathrm{G} / \mathrm{SQ} \mathrm{M}$ & (MG/M2) \\
\hline & $(00027)$ & $(00028)$ & $(00572)$ & $(00573)$ & $(70957)$ \\
\hline JUL 31 -AUG 29 & 1028 & 81213 & 7.12 & 12.9 & 39000 \\
\hline JUL 31 -AUG 29 & 1028 & 81213 & 5.29 & 10.5 & 26000 \\
\hline JUL 31-AUG 29 & 1028 & 81213 & 1.92 & 3.76 & 1180 \\
\hline JUL 31 -AUG 29 & 1028 & 81213 & 5.42 & 11.3 & 1220 \\
\hline
\end{tabular}

\section{SAND CREEK SITE 3B NEAR ARDMORE, OK}

LOCATION.--Lat $34^{\circ} 13^{\prime} 42^{\prime \prime}$, long $97^{\circ} 04^{\prime} 49^{\prime \prime}$, in NE 1/4 NE 1/4 sec.10, T.4 S., R.2 E., Carter County, Hydrologic Unit 11130303, 05 mi east of Atchinson, Topeka, and Sante Fe Railroad tracks, $0.4 \mathrm{mi}$ west of County Road, $2.8 \mathrm{mi}$ north of U. S. Highway 70,3.5 mi northwest of Ardmore City limits, and at mile 1.8.

PERIOD OF RECORD.--October 1996 to August 1997 (discontinued).

\begin{tabular}{lccccc} 
& & \multicolumn{4}{c}{ WATER-QUALITY DATA } \\
& & & & PERI- & CHLOR-A \\
& AGENCY & AGENCY & PERI- & PHYTON & PERI- \\
& COL- & ANA- & PHYTON & BIOMASS & PHYTON \\
& LECTING & LYZING & BIOMASS & TOTAL & CHROMO- \\
& SAMPLE & SAMPLE & ASH & DRY & GRAPHIC \\
DATE & (CODE & (CODE & WEIGHT & WEIGHT & FLUOROM \\
& NUMBER) & NUMBER) & G/SQ M & G/SQ M & (MG/M2) \\
& $(00027)$ & $(00028)$ & $(00572)$ & $(00573)$ & (70957) \\
AUG 01-29 & 1028 & 81213 & 9.20 & 12.4 & 45000 \\
AUG 01-29 & 1028 & 81213 & 12.1 & 16.0 & 2290 \\
AUG 01-29 & 1028 & 81213 & 4.03 & 15.8 & 1730
\end{tabular}


LOCATION.--Lat $34^{\circ} 13^{\prime} 49^{\prime \prime}$, long $97^{\circ} 04^{\prime} 22^{\prime \prime}$, in NW 1/4 NW 1/4 sec.11, T.4 S., R.2 E., Carter County, Hydrologic Unit 11130303, on downstream left bank at county road bridge, $3.0 \mathrm{mi}$ north of U.S. Highway 70,4.0 mi northeast of Ardmore city limits, and at mile 1.1 .

PERIOD OF RECORD.--October 1996 to August 1997 (discontinued).

REMARKS.--Water temperature, specific conductance, $\mathrm{pH}$, alkalinity, and dissolved oxygen were determined in the field.

\begin{tabular}{|c|c|c|c|c|c|c|c|c|c|c|}
\hline & & & & & TER-QU & ITY DATA & & & & \\
\hline DATE & TIME & $\begin{array}{l}\text { AGENCY } \\
\text { COL- } \\
\text { LECTING } \\
\text { SAMPLE } \\
\text { (CODE } \\
\text { NUMBER) } \\
(00027 \text { ) }\end{array}$ & $\begin{array}{l}\text { AGENCY } \\
\text { ANA- } \\
\text { LYZING } \\
\text { SAMPLE } \\
\text { (CODE } \\
\text { NUMBER) } \\
(00028)\end{array}$ & $\begin{array}{c}\text { SPE- } \\
\text { CIFIC } \\
\text { CON- } \\
\text { DUCT- } \\
\text { ANCE } \\
\text { (US/CM) } \\
(00095)\end{array}$ & $\begin{array}{c}\text { PH } \\
\text { WATER } \\
\text { WHOLE } \\
\text { FIELD } \\
\text { (STAND- } \\
\text { ARD } \\
\text { UNITS) } \\
(00400)\end{array}$ & $\begin{array}{c}\text { TEMPER- } \\
\text { ATURE } \\
\text { WATER } \\
(\text { DEG C) } \\
(00010)\end{array}$ & $\begin{array}{c}\text { TUR- } \\
\text { BID- } \\
\text { ITY } \\
\text { (NTU) } \\
(00076)\end{array}$ & $\begin{array}{c}\text { BARO- } \\
\text { METRIC } \\
\text { PRES- } \\
\text { SURE } \\
\text { (MM } \\
\text { OF } \\
\text { HG) } \\
(00025)\end{array}$ & $\begin{array}{l}\text { OXYGEN, } \\
\text { DIS- } \\
\text { SOLVED } \\
(M G / L) \\
(00300)\end{array}$ & $\begin{array}{c}\text { OXYGEN, } \\
\text { DIS- } \\
\text { SOLVED } \\
\text { (PER- } \\
\text { CENT } \\
\text { SATUR- } \\
\text { ATION) } \\
\text { (00301) }\end{array}$ \\
\hline OCT 1 & & & & & & & & & & \\
\hline $\begin{array}{l}18 \ldots \\
\text { JUL } 1\end{array}$ & $\begin{array}{l}1115 \\
97\end{array}$ & 1028 & 81213 & 1110 & 7.4 & 16.5 & 3.1 & 753 & 5.0 & 52 \\
\hline $30 \ldots$ & 0315 & 1028 & 81213 & 1180 & 7.4 & 26.5 & 1.1 & 750 & 3.0 & 38 \\
\hline $30 \ldots$ & 0906 & 1028 & 81213 & 1150 & 7.4 & 26.5 & 1.6 & 750 & 3.9 & 49 \\
\hline $30 \ldots$ & 1455 & 1028 & 81213 & 1250 & 8.0 & 28.5 & $<1.0$ & 760 & 8.7 & 113 \\
\hline $30 \ldots$ & 2050 & 1028 & 81213 & 1430 & 7.5 & 28.0 & $<1.0$ & 750 & 4.1 & 53 \\
\hline $\begin{array}{l}31 \ldots \\
\text { AUG }\end{array}$ & 0245 & 1028 & 81213 & 1500 & 7.4 & 26.0 & $<1.0$ & 751 & 3.4 & 43 \\
\hline $26 \ldots$ & 1145 & 1028 & 81213 & 1690 & 7.3 & 26.0 & 2.1 & 742 & 3.8 & 48 \\
\hline $27 \ldots$ & 0530 & 1028 & 81213 & 1540 & 7.3 & 24.5 & $<1.0$ & 749 & 3.4 & 42 \\
\hline $27 \ldots$ & 1130 & 1028 & 81213 & 1620 & 7.5 & 25.5 & 1.0 & 750 & 5.7 & 71 \\
\hline $27 \ldots$ & 1730 & 1028 & 81213 & 1620 & 7.4 & 28.5 & 2.2 & 743 & 5.4 & 72 \\
\hline $27 \ldots$ & 2330 & 1028 & 81213 & 1510 & 7.3 & 27.0 & $<1.0$ & 749 & 2.8 & 36 \\
\hline
\end{tabular}

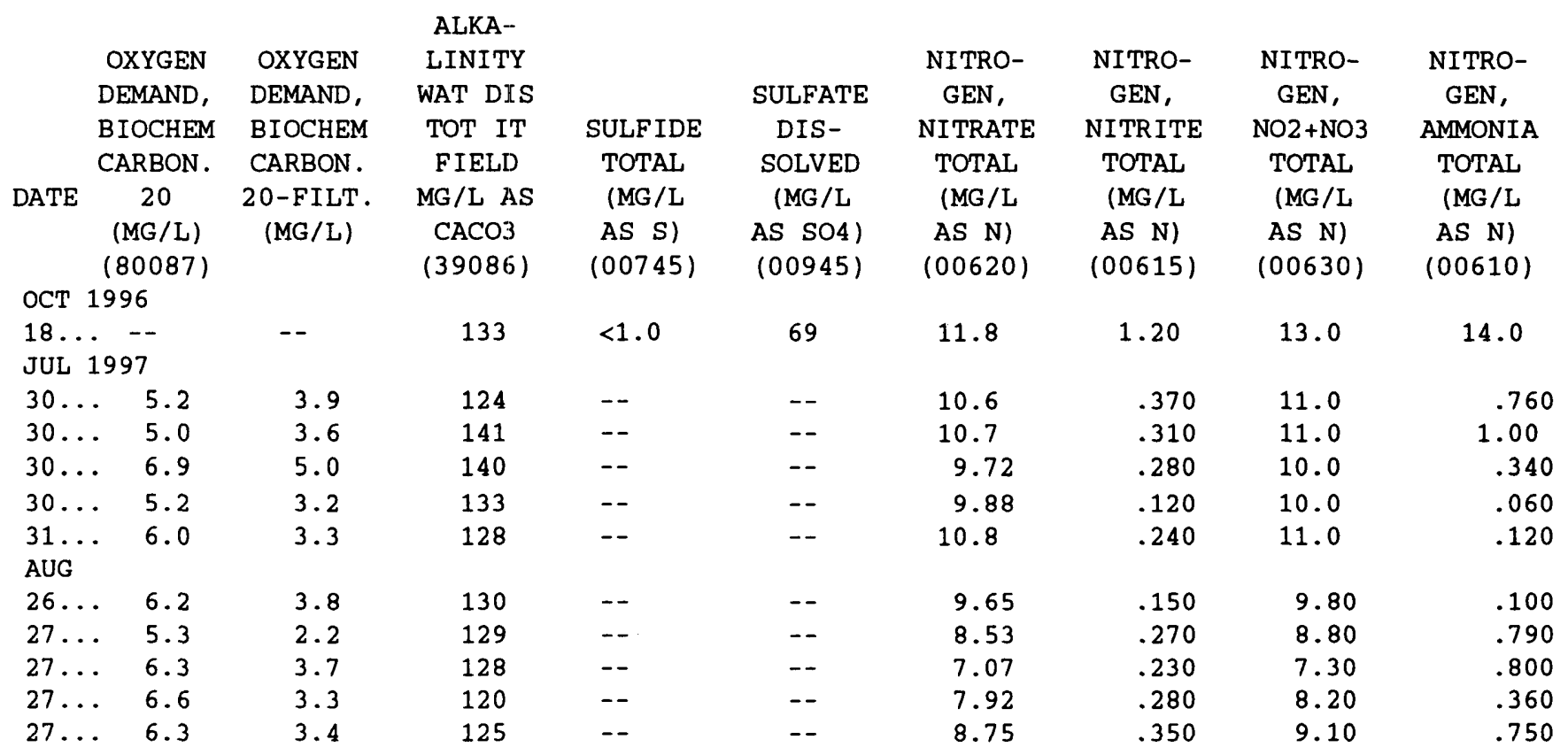


WATER-QUALITY DATA

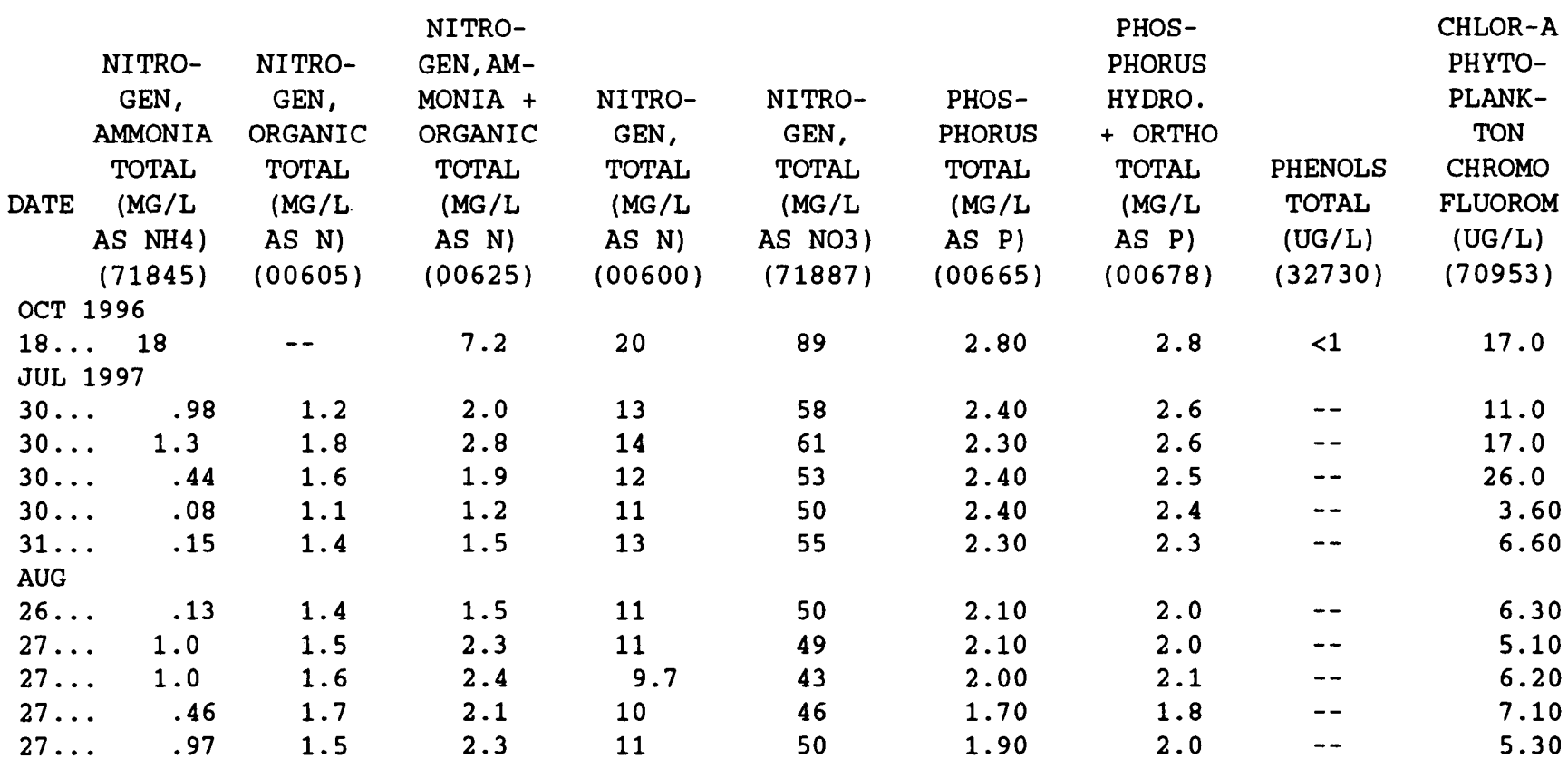

DATE

AUG $01-29$

AUG $01-29$

AUG $01-29$

$\begin{array}{cc}\text { AGENCY } & \text { AGENCY } \\ \text { COL- } & \text { ANA- } \\ \text { LECTING } & \text { LYZING } \\ \text { SAMPLE } & \text { SAMPLE } \\ \text { (CODE } & \text { (CODE } \\ \text { NUMBER) } & \text { NUMBER) } \\ (00027) & (00028) \\ 1028 & 81213 \\ 1028 & 81213 \\ 1028 & 81213\end{array}$

PERI-
PHYTON
BIOMASS
ASH
WEIGHT
G/SQ M
$(00572)$
13.6
E11.6
25.1

$\begin{array}{cc}\text { PERI- } & \text { CHLOR-A } \\ \text { PHYTON } & \text { PERI- } \\ \text { BIOMASS } & \text { PHYTON } \\ \text { TOTAL } & \text { CHROMO- } \\ \text { DRY } & \text { GRAPHIC } \\ \text { WEIGHT } & \text { FLUOROM } \\ \text { G/SQ M } & \text { (MG/M2) } \\ (00573) & (70957) \\ 22.6 & 21000 \\ \text { E13.7 } & 16000 \\ 34.8 & 6390\end{array}$

\begin{tabular}{|c|c|c|c|c|}
\hline \multirow[b]{2}{*}{ DATE } & \multirow[b]{2}{*}{ TIME } & $\begin{array}{c}\text { AGENCY } \\
\text { COL- } \\
\text { LECTING }\end{array}$ & $\begin{array}{c}\text { AGENCY } \\
\text { ANA- } \\
\text { LYZ ING }\end{array}$ & \\
\hline & & $\begin{array}{c}\text { SAMPLE } \\
\text { (CODE } \\
\text { NUMBER) } \\
(00027)\end{array}$ & $\begin{array}{c}\text { SAMPLE } \\
\text { (CODE } \\
\text { NUMBER) } \\
(00028)\end{array}$ & $\begin{array}{c}\text { PROPANE } \\
\text { TOTAL } \\
\text { (UG/L) } \\
(82358)\end{array}$ \\
\hline \multicolumn{5}{|c|}{ JUL 1997} \\
\hline $18 \ldots$ & 0615 & 1028 & 81213 & $<1.0$ \\
\hline $18 \ldots$ & 0645 & 1028 & 81213 & $<1.0$ \\
\hline $18 \ldots$ & 0745 & 1028 & 81213 & $<1.0$ \\
\hline $18 \ldots$ & 0845 & 1028 & 81213 & $<1.0$ \\
\hline $18 \ldots$ & 0945 & 1028 & 81213 & $<1.0$ \\
\hline $18 \ldots$ & 1045 & 1028 & 81213 & $<1.0$ \\
\hline $18 \ldots$ & 1200 & 1028 & 81213 & $<1.0$ \\
\hline $18 \ldots$ & 1345 & 1028 & 81213 & $<1.0$ \\
\hline $18 \ldots$ & 1600 & 1028 & 81213 & $<1.0$ \\
\hline $18 .$. & 2036 & 1028 & 81213 & $<1.0$ \\
\hline
\end{tabular}


LOCATION.--Lat $34^{\circ} 14^{\prime} 12^{\prime \prime}$, long $97^{\circ} 03^{\prime} 39^{\prime \prime}$, in SE 1/4 SE 1/4 sec.2, T.4 S., R.2 E., Carter County, Hydrologic Unit 11130303, on right bank $500 \mathrm{ft}$ downstream from low water crossing on private road, $0.3 \mathrm{mi}$ above Caddo Creek, $3.4 \mathrm{mi}$ north of U.S.Highway 70, 6.5 mi northeast of Ardmore city limits, and at mile 0.3.

PERIOD OF RECORD.--October 1996 to August 1997 (discontinued).

REMARKS.--Water temperature, specific conductance, pH, alkalinity, and dissolved oxygen were determined in the field.

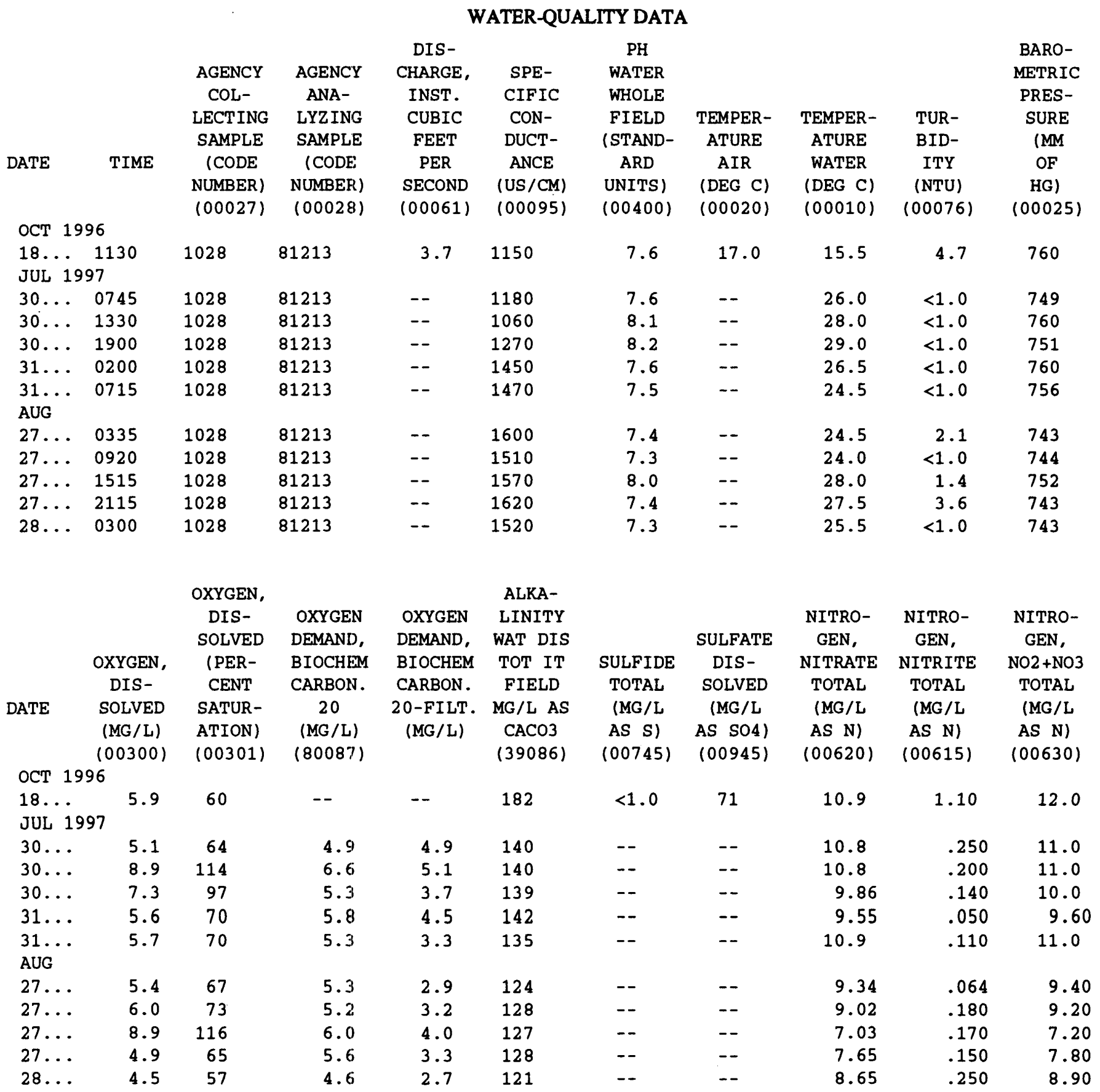


07330680 SAND CREEK SITE 5, COMPARATIVE SAMPLE SITE NEAR ARDMORE, OK--Continued

WATER-QUALITY DATA

\begin{tabular}{|c|c|c|c|c|c|c|c|c|c|c|}
\hline DATE & $\begin{array}{l}\text { NITRO- } \\
\text { GEN, } \\
\text { AMMONIA } \\
\text { TOTAL } \\
\text { (MG/L } \\
\text { AS N) } \\
(00610)\end{array}$ & $\begin{array}{c}\text { NITRO- } \\
\text { GEN, } \\
\text { AMMONIA } \\
\text { TOTAL } \\
\text { (MG/L } \\
\text { AS NH4) } \\
(71845)\end{array}$ & $\begin{array}{l}\text { NITRO- } \\
\text { GEN, } \\
\text { ORGANIC } \\
\text { TOTAL } \\
\text { (MG/L } \\
\text { AS N) } \\
(00605)\end{array}$ & $\begin{array}{c}\text { NITRO- } \\
\text { GEN, AM- } \\
\text { MONIA + } \\
\text { ORGANIC } \\
\text { TOTAL } \\
\text { (MG/L } \\
\text { AS N) } \\
(00625)\end{array}$ & $\begin{array}{l}\text { NITRO- } \\
\text { GEN, } \\
\text { TOTAL } \\
\text { (MG/L } \\
\text { AS N) } \\
(00600)\end{array}$ & $\begin{array}{c}\text { NITRO- } \\
\text { GEN, } \\
\text { TOTAL } \\
\text { (MG/L } \\
\text { AS NO3) } \\
\text { (71887) }\end{array}$ & $\begin{array}{l}\text { PHOS- } \\
\text { PHORUS } \\
\text { TOTAL } \\
\text { (MG/L } \\
\text { AS P) } \\
(00665)\end{array}$ & $\begin{array}{c}\text { PHOS- } \\
\text { PHORUS } \\
\text { HYDRO. } \\
+ \text { ORTHO } \\
\text { TOTAL } \\
\text { (MG/L } \\
\text { AS P) } \\
(00678)\end{array}$ & $\begin{array}{c}\text { TON } \\
\text { PHENOLS } \\
\text { TOTAL } \\
\text { (UG/L) } \\
(32730)\end{array}$ & $\begin{array}{l}\text { CHLOR-A } \\
\text { PHYTO- } \\
\text { PLANK- } \\
\text { CHROMO } \\
\text { FLUOROM } \\
\text { (UG/L) } \\
\text { (70953) }\end{array}$ \\
\hline OCT & & & & & & & & & & \\
\hline $\begin{array}{l}18 . . \\
\text { JUL }\end{array}$ & $97^{13.0}$ & 17 & -- & 6.9 & 19 & 84 & 2.60 & 3.0 & $<1$ & \\
\hline $30 .$. & .420 & .54 & 1.3 & 1.7 & 13 & 56 & 2.30 & 2.5 & -- & 17.0 \\
\hline $30 \ldots$ & .360 & .46 & 1.3 & 1.7 & 13 & 56 & 2.40 & 2.5 & -- & 19.0 \\
\hline $30 .$. & .100 & .13 & 1.3 & 1.4 & 11 & 50 & 2.30 & 2.2 & -- & 14.0 \\
\hline $31 .$. & .050 & .06 & 1.1 & 1.2 & 11 & 48 & 2.20 & 2.3 & -- & 4.00 \\
\hline $\begin{array}{l}31 \ldots \\
\text { AUG }\end{array}$ & .100 & .13 & 1.4 & 1.5 & 13 & 55 & 2.20 & 2.2 & -- & 6.60 \\
\hline $27 \ldots$ & .050 & .06 & 1.5 & 1.6 & 11 & 49 & 2.00 & 2.0 & -- & 7.40 \\
\hline $27 \ldots$ & .270 & .35 & 1.5 & 1.8 & 11 & 49 & 2.10 & 2.0 & -- & 6.40 \\
\hline $27 \ldots$ & .220 & .28 & 1.8 & 2.0 & 9.2 & 41 & 2.00 & 1.9 & -- & 6.30 \\
\hline $27 \ldots$ & .130 & .17 & 1.8 & 1.9 & 9.7 & 43 & 1.80 & 1.9 & -- & 5.50 \\
\hline $28 .$. & .310 & .40 & 1.6 & 1.9 & 11 & 48 & 1.90 & 2.0 & -- & 5.30 \\
\hline
\end{tabular}

DATE

AUG 01-29

AUG 01-29

AUG 01-29

$\begin{array}{cc}\text { AGENCY } & \text { AGENCY } \\ \text { COL- } & \text { ANA- } \\ \text { LECTING } & \text { LYZ ING } \\ \text { SAMPLE } & \text { SAMPLE } \\ \text { (CODE } & \text { (CODE } \\ \text { NUMBER) } & \text { NUMBER) } \\ (00027) & (00028) \\ 1028 & 81213 \\ 1028 & 81213 \\ 1028 & 81213\end{array}$

\begin{tabular}{|c|c|c|c|c|}
\hline \multirow[b]{2}{*}{ DATE } & \multirow[b]{2}{*}{ TIME } & $\begin{array}{c}\text { AGENCY } \\
\text { COL- } \\
\text { LECTING }\end{array}$ & $\begin{array}{c}\text { AGENCY } \\
\text { ANA- } \\
\text { LYZING }\end{array}$ & \\
\hline & & $\begin{array}{c}\text { SAMPLE } \\
\text { (CODE } \\
\text { NUMBER) } \\
(00027)\end{array}$ & $\begin{array}{c}\text { SAMPLE } \\
\text { (CODE } \\
\text { NUMBER) } \\
(00028)\end{array}$ & $\begin{array}{c}\text { PROPANE } \\
\text { TOTAL } \\
\text { (UG/L) } \\
(82358)\end{array}$ \\
\hline \multicolumn{5}{|c|}{ JUL 1997} \\
\hline $18 \ldots$ & 1002 & 1028 & 81213 & $<1.0$ \\
\hline $18 \ldots$ & 1035 & 1028 & 81213 & $<1.0$ \\
\hline $18 \ldots$ & 1143 & 1028 & 81213 & $<1.0$ \\
\hline $18 \ldots$ & 1210 & 1028 & 81213 & $<1.0$ \\
\hline $18 \ldots$ & 1248 & 1028 & 81213 & $<1.0$ \\
\hline $18 \ldots$ & 1336 & 1028 & 81213 & $<1.0$ \\
\hline $18 \ldots$ & 1409 & 1028 & 81213 & $<1.0$ \\
\hline $18 \ldots$ & 1432 & 1028 & 81213 & $<1.0$ \\
\hline $18 \ldots$ & 1454 & 1028 & 81213 & $<1.0$ \\
\hline $18 \ldots$ & 1603 & 1028 & 81213 & $<1.0$ \\
\hline $18 \ldots$ & 1648 & 1028 & 81213 & $<1.0$ \\
\hline $18 \ldots$ & 1733 & 1028 & 81213 & $<1.0$ \\
\hline $18 \ldots$ & 1938 & 1028 & 81213 & $<1.0$ \\
\hline $18 \ldots$ & 2059 & 1028 & 81213 & $<1.0$ \\
\hline
\end{tabular}


LOCATION.--Lat $34^{\circ} 14^{\prime} 25^{\prime \prime}$, long $97^{\circ} 03^{\prime} 05^{\prime \prime}$, in SW 1/4 NW 1/4 sec.1, T.4 S., R.2 E., Carter County, Hydrologic Unit 11130303, on left downstream end of bridge on Gene Autry Road, $2.8 \mathrm{mi}$ south of Gene Autry, $3.7 \mathrm{mi}$ north of U.S. Highway 70, and at mile 9.5.

DRAINAGE AREA.--326 $\mathrm{mi}^{2}$.

\section{WATER-DISCHARGE RECORDS}

PERIOD OF RECORD.--March 1996 to current year.

GAGE.--Water-stage recorder. Datum of gage is $685 \mathrm{ft}$ by barometer.

REMARKS.--Records fair. U.S. Geological Survey's satellite telemeter at station.

DISCHARGE, CUBIC FEET PER SECOND, WATER YEAR OCTOBER 1996 TO SEPTEMBER 1997 DAIL Y MEAN VALUES

\begin{tabular}{|c|c|c|c|c|c|c|c|c|c|c|c|c|}
\hline DAY & OCT & NOV & DEC & JAN & FEB & MAR & APR & MAY & JUN & JUL & AUG & SEP \\
\hline $\begin{array}{l}1 \\
2 \\
3 \\
4 \\
5\end{array}$ & $\begin{array}{r}102 \\
86 \\
73 \\
64 \\
57\end{array}$ & $\begin{array}{l}81 \\
70 \\
58 \\
53 \\
50\end{array}$ & $\begin{array}{r}841 \\
445 \\
e 300 \\
205 \\
169\end{array}$ & $\begin{array}{l}44 \\
44 \\
46 \\
47 \\
42\end{array}$ & $\begin{array}{l}35 \\
35 \\
35 \\
34 \\
34\end{array}$ & $\begin{array}{l}\text { e500 } \\
\text { e350 } \\
\text { e270 } \\
\text { e220 } \\
\text { e190 }\end{array}$ & $\begin{array}{r}45 \\
46 \\
49 \\
131 \\
329\end{array}$ & $\begin{array}{r}172 \\
143 \\
123 \\
107 \\
99\end{array}$ & $\begin{array}{l}758 \\
469 \\
275 \\
194 \\
150\end{array}$ & $\begin{array}{l}39 \\
37 \\
33 \\
31 \\
32\end{array}$ & $\begin{array}{l}17 \\
14 \\
11 \\
10 \\
11\end{array}$ & $\begin{array}{l}9.3 \\
8.9 \\
11 \\
14 \\
15\end{array}$ \\
\hline $\begin{array}{r}6 \\
7 \\
8 \\
9 \\
10\end{array}$ & $\begin{array}{l}53 \\
49 \\
45 \\
62 \\
58\end{array}$ & $\begin{array}{r}50 \\
679 \\
390 \\
148 \\
103\end{array}$ & $\begin{array}{r}400 \\
205 \\
\mathrm{e} 160 \\
\mathrm{e} 140 \\
\mathrm{e} 120\end{array}$ & $\begin{array}{l}39 \\
37 \\
38 \\
42 \\
43\end{array}$ & $\begin{array}{r}46 \\
174 \\
262 \\
138 \\
104\end{array}$ & $\begin{array}{r}164 \\
\text { e140 } \\
\text { e130 } \\
\text { e128 } \\
\text { e150 }\end{array}$ & $\begin{array}{r}222 \\
124 \\
97 \\
84 \\
78\end{array}$ & $\begin{array}{r}95 \\
91 \\
96 \\
585 \\
480\end{array}$ & $\begin{array}{r}122 \\
107 \\
97 \\
191 \\
2420\end{array}$ & $\begin{array}{l}32 \\
31 \\
31 \\
28 \\
27\end{array}$ & $\begin{array}{l}9.8 \\
15 \\
14 \\
14 \\
12\end{array}$ & $\begin{array}{l}13 \\
12 \\
12 \\
11 \\
11\end{array}$ \\
\hline $\begin{array}{l}11 \\
12 \\
13 \\
14 \\
15\end{array}$ & $\begin{array}{l}38 \\
31 \\
31 \\
27 \\
25\end{array}$ & $\begin{array}{l}85 \\
74 \\
69 \\
65 \\
59\end{array}$ & $\begin{array}{l}\text { e94 } \\
\text { e86 } \\
\text { e80 } \\
\text { e78 } \\
\text { e85 }\end{array}$ & $\begin{array}{r}42 \\
\text { e } 43 \\
44 \\
41 \\
39\end{array}$ & $\begin{array}{l}91 \\
83 \\
79 \\
76 \\
73\end{array}$ & $\begin{array}{r}\text { e130 } \\
120 \\
108 \\
105 \\
83\end{array}$ & $\begin{array}{r}1280 \\
1850 \\
664 \\
375 \\
256\end{array}$ & $\begin{array}{r}241 \\
157 \\
115 \\
99 \\
89\end{array}$ & $\begin{array}{l}989 \\
484 \\
341 \\
399 \\
230\end{array}$ & $\begin{array}{l}23 \\
23 \\
21 \\
20 \\
20\end{array}$ & $\begin{array}{l}13 \\
12 \\
13 \\
14 \\
11\end{array}$ & $\begin{array}{l}11 \\
10 \\
8.3 \\
7.5 \\
10\end{array}$ \\
\hline $\begin{array}{l}16 \\
17 \\
18 \\
19 \\
20\end{array}$ & $\begin{array}{l}25 \\
24 \\
23 \\
20 \\
19\end{array}$ & $\begin{array}{r}145 \\
1750 \\
863 \\
408 \\
218\end{array}$ & $\begin{array}{l}78 \\
71 \\
66 \\
59 \\
55\end{array}$ & $\begin{array}{l}39 \\
39 \\
55 \\
63 \\
48\end{array}$ & $\begin{array}{r}69 \\
\text { e60 } \\
\text { e58 } \\
56 \\
5100\end{array}$ & $\begin{array}{l}74 \\
72 \\
74 \\
72 \\
66\end{array}$ & $\begin{array}{l}196 \\
169 \\
151 \\
136 \\
130\end{array}$ & $\begin{array}{r}81 \\
74 \\
69 \\
521 \\
816\end{array}$ & $\begin{array}{r}172 \\
131 \\
172 \\
90 \\
74\end{array}$ & $\begin{array}{l}19 \\
19 \\
20 \\
18 \\
16\end{array}$ & $\begin{array}{c}12 \\
9.3 \\
11 \\
15 \\
19\end{array}$ & $\begin{array}{l}8.4 \\
7.4 \\
7.7 \\
7.5 \\
7.1\end{array}$ \\
\hline $\begin{array}{l}21 \\
22 \\
23 \\
24 \\
25\end{array}$ & $\begin{array}{l}211 \\
378 \\
269 \\
179 \\
143\end{array}$ & $\begin{array}{r}153 \\
117 \\
98 \\
1870 \\
1960\end{array}$ & $\begin{array}{l}63 \\
58 \\
56 \\
56 \\
51\end{array}$ & $\begin{array}{l}48 \\
47 \\
44 \\
44 \\
44\end{array}$ & $\begin{array}{r}5890 \\
\text { e } 3500 \\
\text { e1800 } \\
\text { e1000 } \\
\text { e700 }\end{array}$ & $\begin{array}{l}66 \\
62 \\
57 \\
55 \\
58\end{array}$ & $\begin{array}{l}165 \\
172 \\
139 \\
117 \\
388\end{array}$ & $\begin{array}{l}405 \\
283 \\
211 \\
153 \\
136\end{array}$ & $\begin{array}{l}62 \\
57 \\
68 \\
79 \\
64\end{array}$ & $\begin{array}{l}16 \\
15 \\
15 \\
14 \\
13\end{array}$ & $\begin{array}{l}14 \\
19 \\
19 \\
17 \\
14\end{array}$ & $\begin{array}{l}7.8 \\
9.6 \\
20 \\
12 \\
13\end{array}$ \\
\hline $\begin{array}{l}26 \\
27 \\
28 \\
29 \\
30 \\
31\end{array}$ & $\begin{array}{r}114 \\
79 \\
77 \\
72 \\
62 \\
68\end{array}$ & $\begin{array}{r}1170 \\
887 \\
465 \\
1420 \\
1790 \\
---\end{array}$ & $\begin{array}{l}48 \\
47 \\
48 \\
46 \\
45 \\
44\end{array}$ & $\begin{array}{l}40 \\
39 \\
38 \\
34 \\
36 \\
35\end{array}$ & $\begin{array}{r}\text { e1300 } \\
\text { e1200 } \\
\text { e800 } \\
--- \\
--- \\
---\end{array}$ & $\begin{array}{l}83 \\
65 \\
60 \\
55 \\
52 \\
50\end{array}$ & $\begin{array}{r}1240 \\
907 \\
540 \\
325 \\
223 \\
---\end{array}$ & $\begin{array}{r}174 \\
213 \\
143 \\
120 \\
1440 \\
2520\end{array}$ & $\begin{array}{r}56 \\
54 \\
48 \\
45 \\
43 \\
---\end{array}$ & $\begin{array}{l}13 \\
12 \\
11 \\
12 \\
15 \\
15\end{array}$ & $\begin{array}{r}13 \\
11 \\
11 \\
11 \\
9.7 \\
8.9\end{array}$ & $\begin{array}{c}14 \\
13 \\
10 \\
11 \\
9.8 \\
--\end{array}$ \\
\hline $\begin{array}{l}\text { TOTAL } \\
\text { MEAN } \\
\text { MAX } \\
\text { MIN } \\
\text { AC-FT }\end{array}$ & $\begin{array}{r}2564 \\
82.7 \\
378 \\
19 \\
5090\end{array}$ & $\begin{array}{r}15348 \\
512 \\
1960 \\
50 \\
30440\end{array}$ & $\begin{array}{r}4299 \\
139 \\
841 \\
44 \\
8530\end{array}$ & $\begin{array}{r}1324 \\
42.7 \\
63 \\
34 \\
2630\end{array}$ & $\begin{array}{r}22832 \\
815 \\
5890 \\
34 \\
45290\end{array}$ & $\begin{array}{r}3809 \\
123 \\
500 \\
50 \\
7560\end{array}$ & $\begin{array}{r}10628 \\
354 \\
1850 \\
45 \\
21080\end{array}$ & $\begin{array}{r}10051 \\
324 \\
2520 \\
69 \\
19940\end{array}$ & $\begin{array}{r}8441 \\
281 \\
2420 \\
43 \\
16740\end{array}$ & $\begin{array}{r}671 \\
21.6 \\
39 \\
11 \\
1330\end{array}$ & $\begin{array}{r}404.7 \\
13.1 \\
19 \\
8.9 \\
803\end{array}$ & $\begin{array}{r}322.3 \\
10.7 \\
20 \\
7.1 \\
639\end{array}$ \\
\hline
\end{tabular}

e Estimated 
07330700 CADDO CREEK SITE 7, COMPARATIVE SAMPLE SITE NEAR GENE AUTRY, OK--Continued STATISTICS OF MONTHLY MEAN DATA FOR WATER YEARS 1996 - 1997, BY WATER YEAR (WY)

\begin{tabular}{|c|c|c|c|c|c|c|c|c|c|c|c|c|}
\hline & OCT & NOV & DEC & JAN & FEB & MAR & APR & MAY & JUN & JUL & AUG & SEP \\
\hline $\begin{array}{l}\text { MEAN } \\
\text { MAX }\end{array}$ & $\begin{array}{l}82.7 \\
82.7\end{array}$ & $\begin{array}{l}512 \\
512\end{array}$ & $\begin{array}{l}139 \\
139\end{array}$ & $\begin{array}{l}42.7 \\
42.7\end{array}$ & $\begin{array}{l}815 \\
815\end{array}$ & $\begin{array}{l}123 \\
123\end{array}$ & $\begin{array}{l}247 \\
354\end{array}$ & $\begin{array}{l}172 \\
324\end{array}$ & $\begin{array}{l}166 \\
281\end{array}$ & $\begin{array}{l}16.4 \\
21.6\end{array}$ & $\begin{array}{l}67.2 \\
121\end{array}$ & $\begin{array}{l}132 \\
253\end{array}$ \\
\hline (WY) & 1997 & 1997 & 1997 & 1997 & 1997 & 1997 & 1997 & 1997 & 1997 & 1997 & 1996 & 1996 \\
\hline $\begin{array}{l}\text { MIN } \\
\text { (WY) }\end{array}$ & $\begin{array}{l}82.7 \\
1997\end{array}$ & $\begin{array}{l}512 \\
1997\end{array}$ & $\begin{array}{l}139 \\
1997\end{array}$ & $\begin{array}{l}42.7 \\
1997\end{array}$ & $\begin{array}{l}815 \\
1997\end{array}$ & $\begin{array}{l}123 \\
1997\end{array}$ & $\begin{array}{l}140 \\
1996\end{array}$ & $\begin{array}{l}20.6 \\
1996\end{array}$ & $\begin{array}{l}51.1 \\
1996\end{array}$ & $\begin{array}{l}11.2 \\
1996\end{array}$ & $\begin{array}{l}13.1 \\
1997\end{array}$ & \\
\hline
\end{tabular}

\section{SUMMARY STATISTICS}

ANNUAL TOTAL

ANNUAL MEAN

HIGHEST ANNUAL MEAN

LOWEST ANNUAL MEAN

HIGHEST DAILY MEAN

LOWEST DAILY MEAN

ANNUAL SEVEN-DAY MINIMUM

INSTANTANEOUS PEAK FLOW

INSTANTANEOUS PEAK STAGE

ANNUAL RUNOFF (AC-FT)

10 PERCENT EXCEEDS

50 PERCENT EXCEEDS

90 PERCENT EXCEEDS
1997 WATER YEAR

80694.0

$\begin{aligned} 221 & \\ & \\ 5890 & \text { Feb } 21 \\ 7.1 & \text { Sep } 20 \\ 7.9 & \text { Sep } 16 \\ 7500 & \text { Feb 21 } \\ 27.31 & \text { Feb 21 } \\ 60100 & \\ 473 & \\ 62 & \\ 12 & \end{aligned}$

WATER YEARS 1996 - 97

$\begin{array}{rlll}221 & & & \\ 221 & & 1997 & \\ 221 & & 1997 & \\ 5890 & \text { Feb } 21 & 1997 \\ 4.9 & \text { Jul } 8 & 1996 \\ 7.8 & \text { Jul } 3 & 1996 \\ 7500 & \text { Feb 21 } & 1997 \\ 27.31 & \text { Feb 21 } & 1997 \\ 160200 & & & \\ 400 & & & \\ 51 & & & \\ 11 & & & \end{array}$

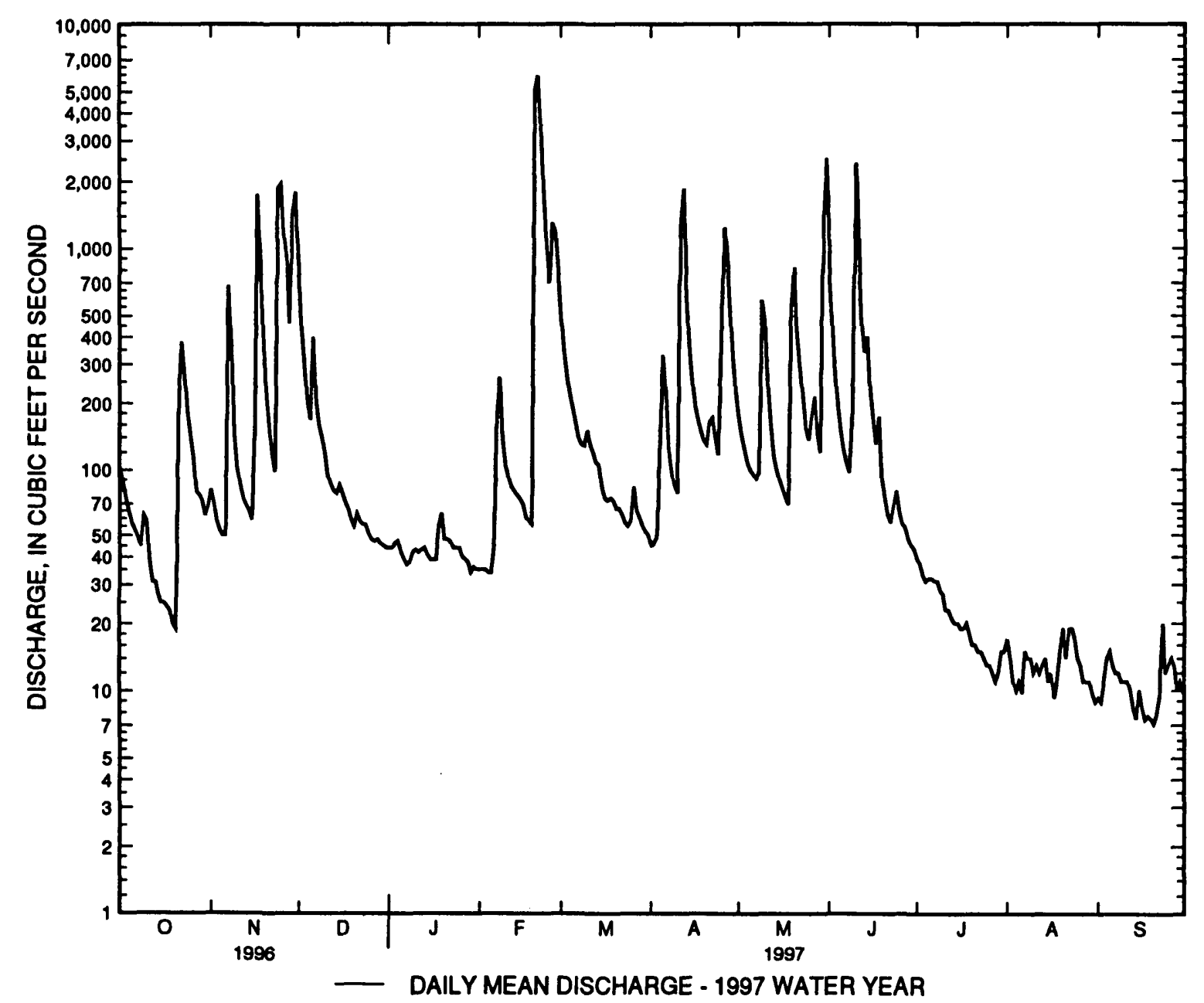


PERIOD OF RECORD.--April 1996 to current year.

PERIOD OF DAILY RECORD.--

SPECIFIC CONDUCTANCE: April 1996 to current year.

$\mathrm{pH}$ : April 1996 to current year.

WATER TEMPERATURE: April 1996 to current year.

DISSOLVED OXYGEN: April 1996 to current year.

INSTRUMENTATION.--Water-quality monitor since April 1996.

REMARKS.--Interruptions in record were due to malfunction of the recording instruments. Water temperature, specific conductance, $\mathrm{pH}$, alkalinity, and dissolved oxygen were determined in the field.

EXTREMES FOR PERIOD OF DAILY RECORD.--

SPECIFIC CONDUCTANCE: Maximum, 1680 microsiemens, Aug. 30, 1997; minimum, 160 microsiemens, Sept. 15, 1996.

pH: Maximum, 9.1 units, July 9, 1996; minimum, 7.4 units, Aug. 9, 11, 1997.

WATER TEMPERATURE: Maximum, 36.0 C, July 3, 1997; minimum, 0.0 C, Dec. 19, 1996.

DISSOLVED OXYGEN: Maximum, $14.6 \mathrm{mg} / \mathrm{L}$, Dec. 19, 1996; minimum, $2.2 \mathrm{mg} / \mathrm{L}$, May 25, 1996, June 26, 1997.

EXTREMES FOR CURRENT YEAR.--

SPECIFIC CONDUCTANCE: Maximum recorded (more than 20\% missing record), 1680 microsiemens, Aug. 30; minimum recorded, 192 microsiemens, Nov. 24.

pH: Maximum recorded (more than 20\% missing record), 8.7 units, June 18; minimum recorded, 7.4 units, Aug. 9, 11.

WATER TEMPERATURE: Maximum recorded (more than $20 \%$ missing record), $36.0^{\circ} \mathrm{C}$, July 3 ; minimum recorded, $0.0^{\circ} \mathrm{C}$, Dec. 19.

DISSOLVED OXYGEN: Maximum recorded (more than $20 \%$ missing record), $14.6 \mathrm{mg} / \mathrm{L}$, Dec. 19; minimum recorded, $2.2 \mathrm{mg} / \mathrm{L}$,

June 26.

WATER-QUALITY DATA

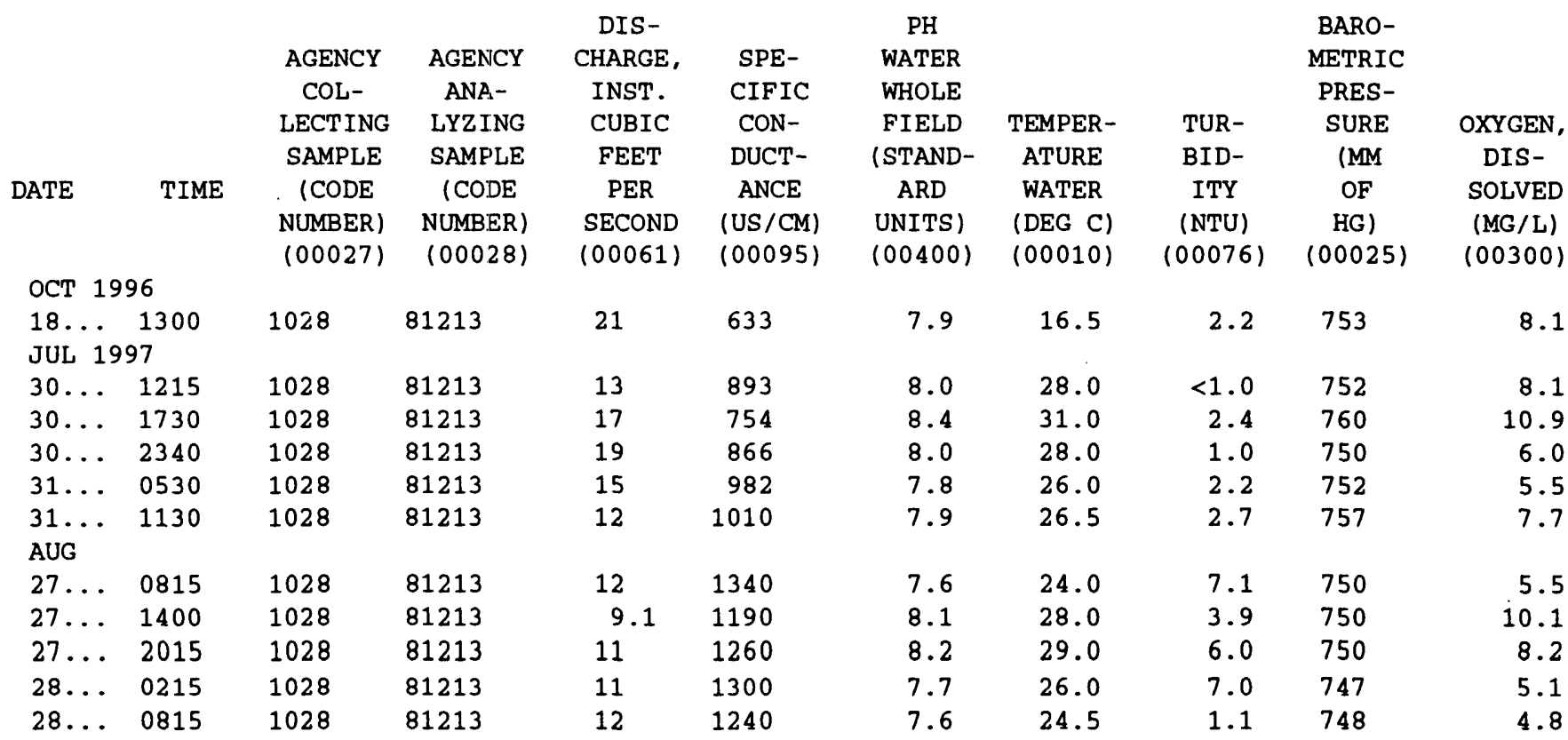


WATER-QUALITY DATA

\begin{tabular}{|c|c|c|c|c|c|c|c|c|c|c|}
\hline DATE & $\begin{array}{l}\text { OXYGEN, } \\
\text { DIS- } \\
\text { SOLVED } \\
\text { (PER- } \\
\text { CENT } \\
\text { SATUR- } \\
\text { ATION) } \\
(00301)\end{array}$ & $\begin{array}{c}\text { OXYGEN } \\
\text { DEMAND, } \\
\text { BIOCHEM } \\
\text { CARBON. } \\
20 \\
(\text { MG } / \mathrm{L}) \\
(80087)\end{array}$ & $\begin{array}{c}\text { OXYGEN } \\
\text { DEMAND, } \\
\text { BIOCHEM } \\
\text { CARBON. } \\
\text { 20-FILT. } \\
\text { (MG/L) }\end{array}$ & $\begin{array}{c}\text { ALKA- } \\
\text { LINITY } \\
\text { WAT DIS } \\
\text { TOT IT } \\
\text { FIELD } \\
\text { MG/L AS } \\
\text { CACO3 } \\
(39086)\end{array}$ & $\begin{array}{c}\text { SULFIDE } \\
\text { TOTAL } \\
\text { (MG/L } \\
\text { AS S) } \\
(00745)\end{array}$ & $\begin{array}{c}\text { SULFATE } \\
\text { DIS- } \\
\text { SOLVED } \\
\text { (MG/L } \\
\text { AS SO4) } \\
(00945)\end{array}$ & $\begin{array}{c}\text { NITRO- } \\
\text { GEN, } \\
\text { NITRATE } \\
\text { TOTAL } \\
\text { (MG/L } \\
\text { AS N) } \\
(00620)\end{array}$ & $\begin{array}{l}\text { NITRO- } \\
\text { GEN, } \\
\text { NITRITE } \\
\text { TOTAL } \\
\text { (MG/L } \\
\text { AS N) } \\
(00615)\end{array}$ & $\begin{array}{l}\text { NITRO- } \\
\text { GEN, } \\
\text { NO2+NO3 } \\
\text { TOTAL } \\
\text { (MG/L } \\
\text { AS N) } \\
(00630)\end{array}$ & $\begin{array}{l}\text { NITRO- } \\
\text { GEN, } \\
\text { AMMONIA } \\
\text { TOTAL } \\
\text { (MG/L } \\
\text { AS N) } \\
(00610)\end{array}$ \\
\hline \multicolumn{11}{|c|}{ OCT 1996} \\
\hline \multicolumn{11}{|c|}{ JUL 1997} \\
\hline $30 \ldots$ & 105 & 2.3 & 1.4 & 161 & -- & -- & 4.21 & .091 & 4.30 & .100 \\
\hline $30 \ldots$ & 148 & 3.0 & 2.4 & 154 & -- & -- & 2.95 & .050 & 3.00 & .070 \\
\hline $30 .$. & 78 & 1.8 & 2.1 & 154 & -- & -- & 3.26 & .042 & 3.30 & .060 \\
\hline $31 \ldots$ & 69 & 2.7 & 2.5 & 154 & -- & -- & 3.77 & .026 & 3.80 & .060 \\
\hline $31 \ldots$ & 97 & 3.6 & 2.1 & 153 & -- & -- & 4.36 & .041 & 4.40 & .070 \\
\hline \multicolumn{11}{|l|}{ AUG } \\
\hline 27. & 131 & 3.4 & 3.2 & 138 & -- & -- & 5.90 & .096 & 6.00 & .080 \\
\hline $27 \ldots$ & 109 & 4.5 & 3.5 & 133 & -- & -- & 5.40 & .097 & 5.50 & .080 \\
\hline 28. & 65 & 3.3 & 2.8 & 134 & -- & -- & 5.30 & .096 & 5.40 & .100 \\
\hline $28 \ldots$ & 59 & 4.3 & 2.6 & 137 & -- & -- & 6.24 & .160 & 6.40 & .200 \\
\hline
\end{tabular}

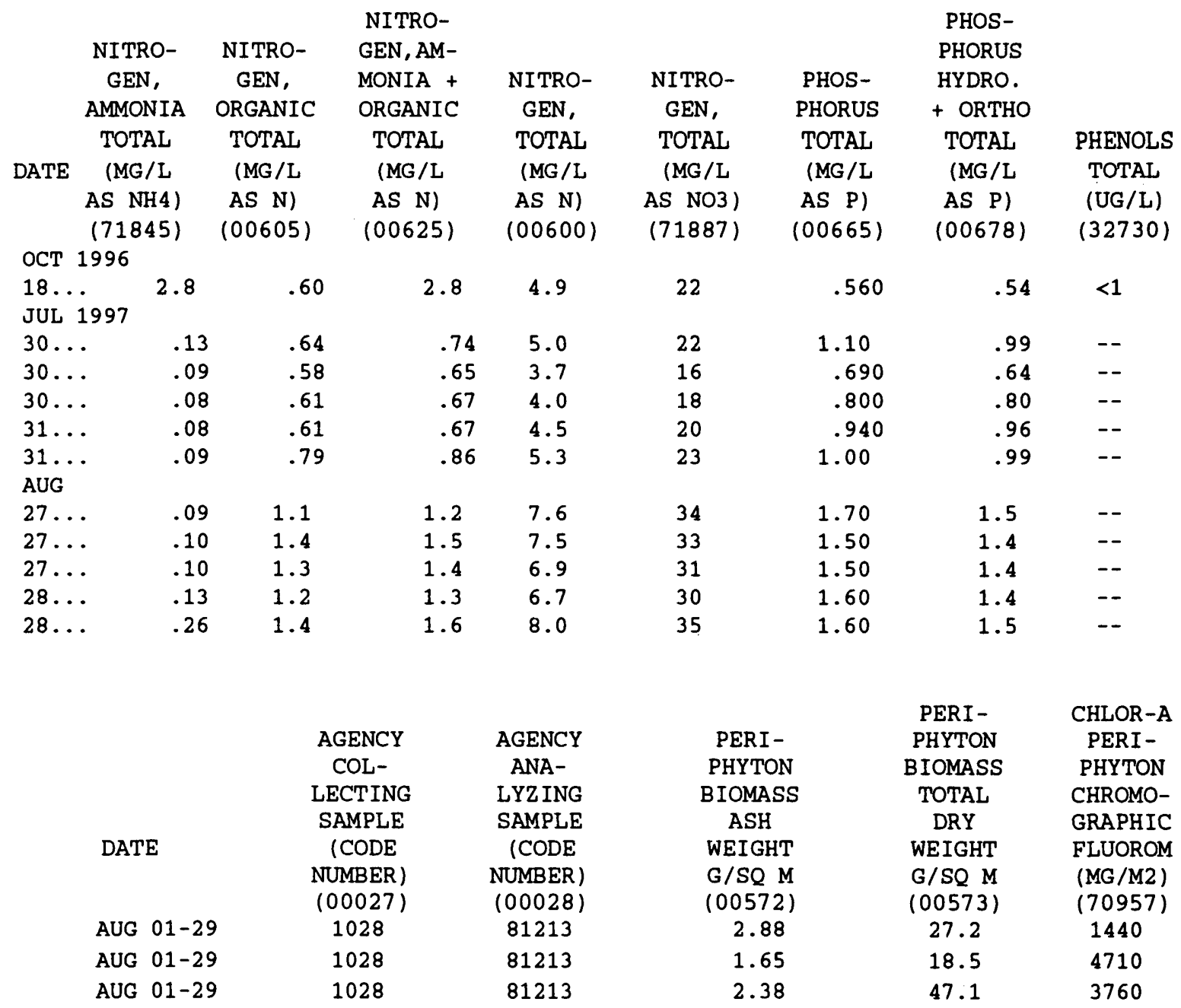




\section{WATER-QUALITY DATA}

\begin{tabular}{|c|c|c|}
\hline AGENCY & AGENCY & \\
\hline $\mathrm{COL}-$ & ANA- & \\
\hline LECTING & LYZ ING & \\
\hline SAMPLE & SAMPLE & PROPANE \\
\hline (CODE & (CODE & TOTAL \\
\hline NUMBER) & NUMBER) & (UG/L) \\
\hline$(00027)$ & $(00028)$ & $(82358)$ \\
\hline 1028 & 81213 & $<1.0$ \\
\hline 1028 & 81213 & $<1.0$ \\
\hline 1028 & 81213 & $<1.0$ \\
\hline 1028 & 81213 & 3.7 \\
\hline 1028 & 81213 & 6.6 \\
\hline 1028 & 81213 & 10.0 \\
\hline 1028 & 81213 & 16.0 \\
\hline 1028 & 81213 & 17.0 \\
\hline 1028 & 81213 & 17.0 \\
\hline 1028 & 81213 & 11.0 \\
\hline 1028 & 81213 & 3.3 \\
\hline 1028 & 81213 & $<1.0$ \\
\hline 1028 & 81213 & $<1.0$ \\
\hline 1028 & 81213 & $<1.0$ \\
\hline 1028 & 81213 & $<1.0$ \\
\hline 1028 & 81213 & $<1.0$ \\
\hline 1028 & 81213 & $<1.0$ \\
\hline 1028 & 81213 & $<1.0$ \\
\hline 1028 & 81213 & $<1.0$ \\
\hline 1028 & 81213 & $<1.0$ \\
\hline 1028 & 81213 & $<1.0$ \\
\hline 1028 & 81213 & $<1.0$ \\
\hline 1028 & 81213 & $<1.0$ \\
\hline 1028 & 81213 & $<1.0$ \\
\hline 1028 & 81213 & $<1.0$ \\
\hline 1028 & 81213 & $<1.0$ \\
\hline 1028 & 81213 & $<1.0$ \\
\hline 1028 & 81213 & $<1.0$ \\
\hline 1028 & 81213 & $<1.0$ \\
\hline 1028 & 81213 & $<1.0$ \\
\hline
\end{tabular}

81213

JUL 1997

$16 \ldots 1425$

$16 \ldots 1440$

$16 \ldots 1450$

$16 \ldots 1500$

$16 \ldots 1512$

$16 \ldots 1522$

$16 \ldots .1540$

$16 \ldots 1600$

$16 \ldots .1615$

$16 . . .1645$

$16 \ldots \quad 1725$

$16 \ldots \quad 1805$

$16 \ldots 1905$

$16 \ldots 2000$

$18 \ldots .1233$

$18 \ldots 1400$

$18 \ldots 1459$

$18 \ldots .1557$

$18 \ldots .1700$

$18 \ldots .1721$

$18 \ldots .1740$

$18 \ldots 1810$

$18 \ldots .1838$

$18 \ldots \quad 1939$

$18 \ldots .2031$

$18 \ldots 2130$

$18 \ldots 2330$

$19 \ldots 0130$

$19 \ldots 0600$

$19 . .1030$ 
07330700 CADDO CREEK SITE 7, COMPARATTVE SAMPLE SITE NEAR GENE AUTRY, OK--Continued SPECIFIC CONDUCTANCE, US/CM @ 25 DEGREES CELSIUS, WATER YEAR OCTOBER 1996 TO SEPTEMBER 1997

\begin{tabular}{|c|c|c|c|c|c|c|c|c|c|c|c|c|}
\hline \multirow[t]{2}{*}{ DAY } & MAX & MIN & MEAN & MAX & MIN & MEAN & MAX & MIN & MEAN & MAX & MIN & MEAN \\
\hline & \multicolumn{3}{|c|}{ OCTOBER } & \multicolumn{3}{|c|}{ NOVEMBER } & \multicolumn{3}{|c|}{ DECEMBER } & \multicolumn{3}{|c|}{ JANUARY } \\
\hline $\begin{array}{l}1 \\
2 \\
3 \\
4 \\
5\end{array}$ & $\begin{array}{l}468 \\
488 \\
664 \\
--- \\
---\end{array}$ & $\begin{array}{l}433 \\
438 \\
483 \\
--- \\
---\end{array}$ & $\begin{array}{l}451 \\
460 \\
528 \\
--- \\
---\end{array}$ & $\begin{array}{l}495 \\
575 \\
689 \\
674 \\
618\end{array}$ & $\begin{array}{l}449 \\
477 \\
575 \\
586 \\
584\end{array}$ & $\begin{array}{l}467 \\
508 \\
662 \\
622 \\
596\end{array}$ & $\begin{array}{l}350 \\
391 \\
434 \\
507 \\
523\end{array}$ & $\begin{array}{l}315 \\
350 \\
391 \\
434 \\
486\end{array}$ & $\begin{array}{l}329 \\
366 \\
410 \\
468 \\
503\end{array}$ & $\begin{array}{l}939 \\
870 \\
869 \\
866 \\
892\end{array}$ & $\begin{array}{l}862 \\
821 \\
813 \\
823 \\
851\end{array}$ & $\begin{array}{l}882 \\
840 \\
845 \\
848 \\
866\end{array}$ \\
\hline $\begin{array}{r}6 \\
7 \\
8 \\
9 \\
10\end{array}$ & $\begin{array}{l}--- \\
--- \\
--- \\
620 \\
526\end{array}$ & $\begin{array}{l}--- \\
--- \\
--- \\
504 \\
469\end{array}$ & $\begin{array}{l}--- \\
--- \\
--- \\
540 \\
503\end{array}$ & $\begin{array}{l}657 \\
611 \\
648 \\
436 \\
451\end{array}$ & $\begin{array}{l}611 \\
225 \\
279 \\
423 \\
434\end{array}$ & $\begin{array}{l}633 \\
309 \\
459 \\
429 \\
440\end{array}$ & $\begin{array}{l}579 \\
563 \\
564 \\
572 \\
566\end{array}$ & $\begin{array}{l}424 \\
429 \\
547 \\
551 \\
541\end{array}$ & $\begin{array}{l}503 \\
464 \\
559 \\
563 \\
555\end{array}$ & $\begin{array}{l}913 \\
952 \\
968 \\
--- \\
---\end{array}$ & $\begin{array}{l}847 \\
850 \\
879 \\
--- \\
---\end{array}$ & $\begin{array}{l}868 \\
888 \\
921 \\
--- \\
---\end{array}$ \\
\hline $\begin{array}{l}11 \\
12 \\
13 \\
14 \\
15\end{array}$ & $\begin{array}{l}572 \\
991 \\
991 \\
757 \\
832\end{array}$ & $\begin{array}{l}484 \\
479 \\
550 \\
612 \\
657\end{array}$ & $\begin{array}{l}521 \\
598 \\
624 \\
658 \\
739\end{array}$ & $\begin{array}{l}487 \\
542 \\
646 \\
705 \\
660\end{array}$ & $\begin{array}{l}451 \\
487 \\
501 \\
592 \\
536\end{array}$ & $\begin{array}{l}462 \\
513 \\
527 \\
647 \\
611\end{array}$ & $\begin{array}{l}610 \\
672 \\
678 \\
684 \\
682\end{array}$ & $\begin{array}{l}539 \\
606 \\
615 \\
617 \\
643\end{array}$ & $\begin{array}{l}570 \\
619 \\
645 \\
666 \\
661\end{array}$ & $\begin{array}{r}--- \\
1020 \\
1040 \\
1020 \\
1040\end{array}$ & $\begin{array}{l}--- \\
933 \\
907 \\
937 \\
975\end{array}$ & $\begin{array}{r}--- \\
979 \\
986 \\
963 \\
1010\end{array}$ \\
\hline $\begin{array}{l}16 \\
17 \\
18 \\
19 \\
20\end{array}$ & $\begin{array}{l}757 \\
723 \\
660 \\
691 \\
857\end{array}$ & $\begin{array}{l}597 \\
612 \\
599 \\
616 \\
651\end{array}$ & $\begin{array}{l}667 \\
661 \\
637 \\
649 \\
745\end{array}$ & $\begin{array}{l}--- \\
--- \\
366 \\
371 \\
421\end{array}$ & $\begin{array}{l}--- \\
--- \\
312 \\
356 \\
371\end{array}$ & $\begin{array}{l}--- \\
--- \\
351 \\
363 \\
392\end{array}$ & $\begin{array}{l}699 \\
758 \\
758 \\
764 \\
792\end{array}$ & $\begin{array}{l}649 \\
684 \\
706 \\
718 \\
726\end{array}$ & $\begin{array}{l}671 \\
712 \\
732 \\
749 \\
758\end{array}$ & $\begin{array}{r}979 \\
1050 \\
1040 \\
1030 \\
889\end{array}$ & $\begin{array}{l}942 \\
905 \\
932 \\
700 \\
649\end{array}$ & $\begin{array}{l}959 \\
961 \\
980 \\
780 \\
752\end{array}$ \\
\hline $\begin{array}{l}21 \\
22 \\
23 \\
24 \\
25\end{array}$ & $\begin{array}{l}--- \\
--- \\
430 \\
443 \\
463\end{array}$ & $\begin{array}{l}--- \\
--- \\
382 \\
403 \\
421\end{array}$ & $\begin{array}{l}--- \\
--- \\
403 \\
430 \\
433\end{array}$ & $\begin{array}{l}441 \\
485 \\
516 \\
505 \\
325\end{array}$ & $\begin{array}{l}421 \\
441 \\
485 \\
192 \\
272\end{array}$ & $\begin{array}{l}434 \\
463 \\
499 \\
297 \\
281\end{array}$ & $\begin{array}{l}782 \\
801 \\
805 \\
828 \\
818\end{array}$ & $\begin{array}{l}716 \\
748 \\
764 \\
786 \\
796\end{array}$ & $\begin{array}{l}746 \\
773 \\
780 \\
798 \\
808\end{array}$ & $\begin{array}{l}887 \\
866 \\
882 \\
920 \\
928\end{array}$ & $\begin{array}{l}818 \\
835 \\
821 \\
796 \\
789\end{array}$ & $\begin{array}{l}853 \\
852 \\
850 \\
855 \\
879\end{array}$ \\
\hline $\begin{array}{l}26 \\
27 \\
28 \\
29 \\
30 \\
31\end{array}$ & $\begin{array}{l}472 \\
532 \\
707 \\
577 \\
520 \\
795\end{array}$ & $\begin{array}{l}425 \\
470 \\
527 \\
470 \\
491 \\
495\end{array}$ & $\begin{array}{l}442 \\
487 \\
585 \\
494 \\
507 \\
557\end{array}$ & $\begin{array}{l}356 \\
355 \\
386 \\
394 \\
392 \\
---\end{array}$ & $\begin{array}{l}283 \\
336 \\
355 \\
237 \\
278 \\
---\end{array}$ & $\begin{array}{l}310 \\
345 \\
371 \\
309 \\
304 \\
--\end{array}$ & $\begin{array}{l}833 \\
848 \\
847 \\
887 \\
894 \\
939\end{array}$ & $\begin{array}{l}792 \\
809 \\
814 \\
826 \\
864 \\
853\end{array}$ & $\begin{array}{l}811 \\
823 \\
827 \\
845 \\
878 \\
884\end{array}$ & $\begin{array}{r}895 \\
891 \\
966 \\
1080 \\
1020 \\
969\end{array}$ & $\begin{array}{l}837 \\
819 \\
840 \\
870 \\
845 \\
835\end{array}$ & $\begin{array}{l}865 \\
856 \\
883 \\
954 \\
949 \\
928\end{array}$ \\
\hline NTH & --- & --- & --- & $-\cdots$ & --- & --- & 939 & 315 & 661 & --- & -- & --- \\
\hline
\end{tabular}


07330700 CADDO CREEK SITE 7, COMPARATIVE SAMPLE SITE NEAR GENE AUTRY, OK--Continued

SPECIFIC CONDUCTANCE, US/CM @ 25 DEGREES CELSIUS, WATER YEAR OCTOBER 1996 TO SEPTEMBER 1997

\begin{tabular}{|c|c|c|c|c|c|c|c|c|c|c|c|c|}
\hline \multirow[t]{2}{*}{ DAY } & MAX & MIN & MEAN & MAX & MIN & MEAN & MAX & MIN & MEAN & MAX & MIN & MEAN \\
\hline & \multicolumn{3}{|c|}{ FEBRUARY } & \multicolumn{3}{|c|}{ MARCH } & \multicolumn{3}{|c|}{ APRIL } & \multicolumn{3}{|c|}{ MAY } \\
\hline $\begin{array}{l}1 \\
2 \\
3 \\
4 \\
5\end{array}$ & $\begin{array}{l}1020 \\
1030 \\
1110 \\
1190 \\
1190\end{array}$ & $\begin{array}{r}835 \\
939 \\
984 \\
1060 \\
1070\end{array}$ & $\begin{array}{r}961 \\
975 \\
1040 \\
1120 \\
1150\end{array}$ & $\begin{array}{l}507 \\
553 \\
580 \\
618 \\
646\end{array}$ & $\begin{array}{l}439 \\
507 \\
542 \\
580 \\
618\end{array}$ & $\begin{array}{l}474 \\
528 \\
555 \\
601 \\
630\end{array}$ & $\begin{array}{r}--- \\
--- \\
--- \\
--- \\
>1000\end{array}$ & $\begin{array}{l}--- \\
--- \\
--- \\
--- \\
738\end{array}$ & $\begin{array}{l}--- \\
--- \\
--- \\
--- \\
880\end{array}$ & $\begin{array}{l}702 \\
730 \\
740 \\
774 \\
783\end{array}$ & $\begin{array}{l}633 \\
676 \\
706 \\
738 \\
768\end{array}$ & $\begin{array}{l}668 \\
697 \\
724 \\
761 \\
775\end{array}$ \\
\hline $\begin{array}{r}6 \\
7 \\
8 \\
9 \\
10\end{array}$ & $\begin{array}{r}1290 \\
1120 \\
918 \\
810 \\
769\end{array}$ & $\begin{array}{r}1100 \\
536 \\
557 \\
718 \\
738\end{array}$ & $\begin{array}{r}1180 \\
754 \\
739 \\
743 \\
754\end{array}$ & $\begin{array}{l}--- \\
--- \\
720 \\
738 \\
870\end{array}$ & $\begin{array}{l}--- \\
--- \\
696 \\
709 \\
723\end{array}$ & $\begin{array}{l}--- \\
--- \\
702 \\
721 \\
758\end{array}$ & $\begin{array}{l}879 \\
762 \\
771 \\
791 \\
872\end{array}$ & $\begin{array}{l}758 \\
718 \\
734 \\
751 \\
791\end{array}$ & $\begin{array}{l}791 \\
735 \\
747 \\
763 \\
830\end{array}$ & $\begin{array}{r}823 \\
1000 \\
1010 \\
1020 \\
532\end{array}$ & $\begin{array}{l}780 \\
827 \\
892 \\
464 \\
457\end{array}$ & $\begin{array}{l}795 \\
912 \\
971 \\
700 \\
509\end{array}$ \\
\hline $\begin{array}{l}11 \\
12 \\
13 \\
14 \\
15\end{array}$ & $\begin{array}{l}834 \\
822 \\
831 \\
841 \\
858\end{array}$ & $\begin{array}{l}745 \\
746 \\
781 \\
760 \\
817\end{array}$ & $\begin{array}{l}766 \\
786 \\
799 \\
799 \\
839\end{array}$ & $\begin{array}{l}945 \\
785 \\
754 \\
845 \\
903\end{array}$ & $\begin{array}{l}785 \\
710 \\
723 \\
732 \\
845\end{array}$ & $\begin{array}{l}867 \\
732 \\
739 \\
756 \\
879\end{array}$ & $\begin{array}{l}867 \\
393 \\
439 \\
513 \\
589\end{array}$ & $\begin{array}{l}247 \\
316 \\
385 \\
439 \\
513\end{array}$ & $\begin{array}{l}497 \\
352 \\
412 \\
475 \\
547\end{array}$ & $\begin{array}{l}563 \\
626 \\
761 \\
807 \\
929\end{array}$ & $\begin{array}{l}519 \\
563 \\
626 \\
728 \\
807\end{array}$ & $\begin{array}{l}536 \\
584 \\
694 \\
758 \\
840\end{array}$ \\
\hline $\begin{array}{l}16 \\
17 \\
18 \\
19 \\
20\end{array}$ & $\begin{array}{l}861 \\
910 \\
910 \\
913 \\
---\end{array}$ & $\begin{array}{l}820 \\
857 \\
864 \\
657 \\
---\end{array}$ & $\begin{array}{l}844 \\
880 \\
887 \\
885 \\
---\end{array}$ & $\begin{array}{l}905 \\
882 \\
895 \\
--- \\
---\end{array}$ & $\begin{array}{l}869 \\
838 \\
869 \\
--- \\
---\end{array}$ & $\begin{array}{l}883 \\
861 \\
882 \\
--- \\
---\end{array}$ & $\begin{array}{l}662 \\
730 \\
840 \\
840 \\
882\end{array}$ & $\begin{array}{l}589 \\
647 \\
659 \\
675 \\
776\end{array}$ & $\begin{array}{l}619 \\
672 \\
729 \\
731 \\
840\end{array}$ & $\begin{array}{r}993 \\
1010 \\
969 \\
994 \\
566\end{array}$ & $\begin{array}{l}889 \\
903 \\
893 \\
297 \\
304\end{array}$ & $\begin{array}{l}918 \\
941 \\
918 \\
598 \\
436\end{array}$ \\
\hline $\begin{array}{l}21 \\
22 \\
23 \\
24 \\
25\end{array}$ & $\begin{array}{l}278 \\
326 \\
354 \\
372 \\
416\end{array}$ & $\begin{array}{l}228 \\
278 \\
324 \\
354 \\
372\end{array}$ & $\begin{array}{l}248 \\
309 \\
339 \\
362 \\
392\end{array}$ & $\begin{array}{l}--- \\
--- \\
--- \\
--- \\
---\end{array}$ & $\begin{array}{l}--- \\
--- \\
--- \\
--- \\
---\end{array}$ & $\begin{array}{l}--- \\
--- \\
--- \\
--- \\
---\end{array}$ & $\begin{array}{l}856 \\
791 \\
825 \\
994 \\
980\end{array}$ & $\begin{array}{l}761 \\
670 \\
659 \\
825 \\
333\end{array}$ & $\begin{array}{l}814 \\
706 \\
730 \\
920 \\
776\end{array}$ & $\begin{array}{l}494 \\
510 \\
540 \\
615 \\
679\end{array}$ & $\begin{array}{l}417 \\
481 \\
509 \\
540 \\
615\end{array}$ & $\begin{array}{l}454 \\
491 \\
518 \\
577 \\
643\end{array}$ \\
\hline $\begin{array}{l}26 \\
27 \\
28 \\
29 \\
30 \\
31\end{array}$ & $\begin{array}{l}492 \\
450 \\
439 \\
--- \\
--- \\
---\end{array}$ & $\begin{array}{l}316 \\
341 \\
369 \\
--- \\
--- \\
---\end{array}$ & $\begin{array}{l}387 \\
363 \\
402 \\
--- \\
--- \\
---\end{array}$ & $\begin{array}{l}--- \\
--- \\
--- \\
--- \\
--- \\
---\end{array}$ & $\begin{array}{l}--- \\
--- \\
--- \\
--- \\
--- \\
---\end{array}$ & $\begin{array}{l}--- \\
--- \\
--- \\
--- \\
--- \\
---\end{array}$ & $\begin{array}{l}759 \\
530 \\
525 \\
565 \\
633 \\
---\end{array}$ & $\begin{array}{l}367 \\
457 \\
491 \\
525 \\
565 \\
---\end{array}$ & $\begin{array}{l}481 \\
484 \\
506 \\
549 \\
593 \\
---\end{array}$ & $\begin{array}{l}770 \\
789 \\
623 \\
599 \\
611 \\
359\end{array}$ & $\begin{array}{l}619 \\
623 \\
599 \\
570 \\
223 \\
217\end{array}$ & $\begin{array}{l}693 \\
686 \\
611 \\
585 \\
411 \\
302\end{array}$ \\
\hline MONTH & -- & --- & --- & -- & --- & --- & --- & -- & --- & 1020 & 217 & 668 \\
\hline
\end{tabular}

$>$ Actual value is known to be greater than the value shown 
07330700 CADDO CREEK SITE 7, COMPARATIVE SAMPLE SITE NEAR GENE AUTRY, OK--Continued SPECIFIC CONDUCTANCE, US/CM @ 25 DEGREES CELSIUS, WATER YEAR OCTOBER 1996 TO SEPTEMBER 1997

\begin{tabular}{|c|c|c|c|c|c|c|c|c|c|c|c|c|}
\hline \multirow[t]{2}{*}{ DAY } & MAX & MIN & MEAN & MAX & MIN & MEAN & MAX & MIN & MEAN & MAX & MIN & MEAN \\
\hline & & JUNE & & \multicolumn{3}{|c|}{ JULY } & \multicolumn{3}{|c|}{ AUGUST } & \multicolumn{3}{|c|}{ SEPTEMBER } \\
\hline $\begin{array}{l}1 \\
2 \\
3 \\
4 \\
5\end{array}$ & $\begin{array}{l}446 \\
516 \\
582 \\
650 \\
749\end{array}$ & $\begin{array}{l}359 \\
446 \\
516 \\
582 \\
650\end{array}$ & $\begin{array}{l}404 \\
481 \\
539 \\
624 \\
705\end{array}$ & $\begin{array}{r}991 \\
991 \\
1020 \\
1030 \\
1010\end{array}$ & $\begin{array}{l}924 \\
933 \\
969 \\
992 \\
882\end{array}$ & $\begin{array}{r}959 \\
966 \\
990 \\
1010 \\
938\end{array}$ & $\begin{array}{r}962 \\
1120 \\
1230 \\
1320 \\
1420\end{array}$ & $\begin{array}{r}815 \\
927 \\
956 \\
1070 \\
1090\end{array}$ & $\begin{array}{r}892 \\
1000 \\
1090 \\
1180 \\
1190\end{array}$ & $\begin{array}{r}1320 \\
1300 \\
1210 \\
1560 \\
895\end{array}$ & $\begin{array}{r}1220 \\
1200 \\
1010 \\
819 \\
740\end{array}$ & $\begin{array}{r}1280 \\
1230 \\
1100 \\
1060 \\
798\end{array}$ \\
\hline $\begin{array}{r}6 \\
7 \\
8 \\
9 \\
10\end{array}$ & $\begin{array}{l}818 \\
882 \\
903 \\
932 \\
431\end{array}$ & $\begin{array}{l}749 \\
818 \\
833 \\
280 \\
231\end{array}$ & $\begin{array}{l}783 \\
854 \\
884 \\
829 \\
314\end{array}$ & $\begin{array}{r}953 \\
900 \\
1010 \\
1040 \\
1070\end{array}$ & $\begin{array}{l}827 \\
827 \\
848 \\
853 \\
891\end{array}$ & $\begin{array}{r}890 \\
869 \\
923 \\
905 \\
1030\end{array}$ & $\begin{array}{r}1170 \\
1140 \\
1040 \\
1510 \\
953\end{array}$ & $\begin{array}{l}982 \\
740 \\
697 \\
641 \\
823\end{array}$ & $\begin{array}{r}1120 \\
884 \\
891 \\
1100 \\
888\end{array}$ & $\begin{array}{r}890 \\
1060 \\
947 \\
1000 \\
961\end{array}$ & $\begin{array}{l}786 \\
750 \\
846 \\
856 \\
866\end{array}$ & $\begin{array}{l}841 \\
854 \\
882 \\
916 \\
904\end{array}$ \\
\hline $\begin{array}{l}11 \\
12 \\
13 \\
14 \\
15\end{array}$ & $\begin{array}{l}380 \\
407 \\
497 \\
--- \\
---\end{array}$ & $\begin{array}{l}326 \\
359 \\
387 \\
--- \\
--\end{array}$ & $\begin{array}{l}360 \\
375 \\
406 \\
--- \\
---\end{array}$ & $\begin{array}{c}1020 \\
--- \\
-- \\
-- \\
--\end{array}$ & $\begin{array}{l}879 \\
--- \\
--- \\
---\end{array}$ & $\begin{array}{c}962 \\
--- \\
--- \\
--- \\
--\end{array}$ & $\begin{array}{c}1140 \\
-- \\
-- \\
-- \\
---\end{array}$ & $\begin{array}{l}827 \\
--- \\
--- \\
--- \\
--\end{array}$ & $\begin{array}{l}923 \\
--- \\
--- \\
--- \\
---\end{array}$ & $\begin{array}{l}1010 \\
1040 \\
1180 \\
1180 \\
1090\end{array}$ & $\begin{array}{r}889 \\
918 \\
1020 \\
1030 \\
637\end{array}$ & $\begin{array}{r}922 \\
958 \\
1080 \\
1090 \\
746\end{array}$ \\
\hline $\begin{array}{l}16 \\
17 \\
18 \\
19 \\
20\end{array}$ & $\begin{array}{l}--- \\
--- \\
--- \\
772 \\
789\end{array}$ & $\begin{array}{l}--- \\
--- \\
--- \\
652 \\
663\end{array}$ & $\begin{array}{l}--- \\
--- \\
694 \\
743\end{array}$ & $\begin{array}{l}--- \\
--- \\
--- \\
990 \\
950\end{array}$ & $\begin{array}{l}--- \\
--- \\
-- \\
799 \\
832\end{array}$ & $\begin{array}{l}--- \\
--- \\
-- \\
903 \\
892\end{array}$ & $\begin{array}{l}--- \\
--- \\
--- \\
--- \\
--\end{array}$ & $\begin{array}{l}--- \\
--- \\
-- \\
--- \\
\end{array}$ & $\begin{array}{l}--- \\
--- \\
--- \\
---\end{array}$ & $\begin{array}{l}--- \\
--- \\
--- \\
---\end{array}$ & $\begin{array}{l}--- \\
--- \\
-- \\
---\end{array}$ & $\begin{array}{l}--- \\
--- \\
--- \\
---\end{array}$ \\
\hline $\begin{array}{l}21 \\
22 \\
23 \\
24 \\
25\end{array}$ & $\begin{array}{r}832 \\
877 \\
>1000 \\
920 \\
-.-\end{array}$ & $\begin{array}{l}708 \\
773 \\
817 \\
655 \\
---\end{array}$ & $\begin{array}{l}788 \\
826 \\
882 \\
771 \\
---\end{array}$ & $\begin{array}{r}1040 \\
1090 \\
1090 \\
939 \\
1130\end{array}$ & $\begin{array}{l}891 \\
999 \\
795 \\
781 \\
920\end{array}$ & $\begin{array}{r}947 \\
1040 \\
941 \\
872 \\
1020\end{array}$ & $\begin{array}{l}--- \\
--- \\
--- \\
--- \\
---\end{array}$ & $\begin{array}{l}--- \\
--- \\
--- \\
--- \\
---\end{array}$ & $\begin{array}{l}--- \\
--- \\
--- \\
--- \\
--\end{array}$ & $\begin{array}{l}--- \\
--- \\
--- \\
---\end{array}$ & $\begin{array}{l}--- \\
-- \\
--- \\
---\end{array}$ & $\begin{array}{l}--- \\
--- \\
--- \\
--- \\
---\end{array}$ \\
\hline $\begin{array}{l}26 \\
27 \\
28 \\
29 \\
30 \\
31\end{array}$ & $\begin{array}{r}--- \\
1010 \\
968 \\
986 \\
980 \\
---\end{array}$ & $\begin{array}{l}--- \\
833 \\
922 \\
927 \\
931 \\
---\end{array}$ & $\begin{array}{l}--- \\
930 \\
945 \\
953 \\
948 \\
---\end{array}$ & $\begin{array}{c}1090 \\
--- \\
-- \\
-- \\
-- \\
1010\end{array}$ & $\begin{array}{c}1020 \\
-\ldots- \\
--- \\
--- \\
853\end{array}$ & $\begin{array}{r}1060 \\
--- \\
-- \\
-- \\
931\end{array}$ & $\begin{array}{l}---- \\
1270 \\
1330 \\
1550 \\
1680 \\
1600\end{array}$ & $\begin{array}{r}--- \\
1010 \\
1080 \\
1330 \\
1470 \\
1220\end{array}$ & $\begin{array}{r}--- \\
1140 \\
1190 \\
1470 \\
1610 \\
1350\end{array}$ & $\begin{array}{r}1410 \\
1320 \\
1230 \\
1360 \\
1390 \\
-.--\end{array}$ & $\begin{array}{r}958 \\
868 \\
944 \\
1080 \\
982 \\
---\end{array}$ & $\begin{array}{r}1150 \\
1020 \\
1090 \\
1260 \\
1190 \\
----\end{array}$ \\
\hline NTH & -- & --- & -- & -- & -- & -.- & --- & -- & -- & --- & --- & -- \\
\hline
\end{tabular}

$>$ Actual value is known to be greater than the value shown 
07330700 CADDO CREEK SITE 7, COMPARATIVE SAMPLE SITE NEAR GENE AUTRY, OK--Continued

PH, WATER, WHOLE, FIELD, STANDARD UNITS, WATER YEAR OCTOBER 1996 TO SEPTEMBER 1997

\begin{tabular}{|c|c|c|c|c|c|c|c|c|c|c|c|c|}
\hline \multirow[t]{2}{*}{ DAY } & MAX & MIN & MEDIAN & MAX & MIN & MEDIAN & MAX & MIN & MEDIAN & MAX & MIN & MEDIAN \\
\hline & \multicolumn{3}{|c|}{ OCTOBER } & \multicolumn{3}{|c|}{ NOVEMBER } & \multicolumn{3}{|c|}{ DECEMBER } & \multicolumn{3}{|c|}{ JANUARY } \\
\hline $\begin{array}{l}1 \\
2 \\
3 \\
4 \\
5\end{array}$ & $\begin{array}{c}8.3 \\
8.3 \\
--- \\
--- \\
---\end{array}$ & $\begin{array}{c}8.3 \\
8.3 \\
--- \\
--- \\
---\end{array}$ & $\begin{array}{c}8.3 \\
8.3 \\
--- \\
--- \\
---\end{array}$ & $\begin{array}{l}8.3 \\
8.3 \\
8.4 \\
8.3 \\
8.4\end{array}$ & $\begin{array}{l}8.1 \\
8.3 \\
8.3 \\
8.3 \\
8.3\end{array}$ & $\begin{array}{l}8.2 \\
8.3 \\
8.3 \\
8.3 \\
8.3\end{array}$ & $\begin{array}{l}8.2 \\
8.2 \\
8.3 \\
8.4 \\
8.5\end{array}$ & $\begin{array}{l}8.2 \\
8.2 \\
8.2 \\
8.3 \\
8.4\end{array}$ & $\begin{array}{l}8.2 \\
8.2 \\
8.3 \\
8.4 \\
8.5\end{array}$ & $\begin{array}{l}8.3 \\
8.3 \\
8.4 \\
8.4 \\
8.4\end{array}$ & $\begin{array}{l}8.1 \\
8.1 \\
8.1 \\
8.2 \\
8.2\end{array}$ & $\begin{array}{l}8.1 \\
8.2 \\
8.2 \\
8.3 \\
8.2\end{array}$ \\
\hline $\begin{array}{r}6 \\
7 \\
8 \\
9 \\
10\end{array}$ & $\begin{array}{l}--- \\
--- \\
-- \\
8.6 \\
8.6\end{array}$ & $\begin{array}{r}--- \\
--- \\
--- \\
8.5 \\
8.4\end{array}$ & $\begin{array}{r}--- \\
--- \\
--- \\
8.5 \\
8.5\end{array}$ & $\begin{array}{l}8.4 \\
8.1 \\
8.2 \\
8.3 \\
8.3\end{array}$ & $\begin{array}{l}8.1 \\
7.9 \\
8.0 \\
8.2 \\
8.3\end{array}$ & $\begin{array}{l}8.3 \\
8.0 \\
8.1 \\
8.3 \\
8.3\end{array}$ & $\begin{array}{l}8.6 \\
8.4 \\
8.4 \\
8.4 \\
8.4\end{array}$ & $\begin{array}{l}8.4 \\
8.4 \\
8.4 \\
8.4 \\
8.4\end{array}$ & $\begin{array}{l}8.5 \\
8.4 \\
8.4 \\
8.4 \\
8.4\end{array}$ & $\begin{array}{r}8.4 \\
8.3 \\
8.4 \\
--\end{array}$ & $\begin{array}{c}8.2 \\
8.1 \\
8.2 \\
---\end{array}$ & $\begin{array}{c}8.3 \\
8.2 \\
8.2 \\
-- \\
--\end{array}$ \\
\hline $\begin{array}{l}11 \\
12 \\
13 \\
14 \\
15\end{array}$ & $\begin{array}{l}8.5 \\
8.5 \\
8.5 \\
8.5 \\
8.5\end{array}$ & $\begin{array}{l}8.3 \\
8.3 \\
8.2 \\
8.1 \\
8.3\end{array}$ & $\begin{array}{l}8.5 \\
8.4 \\
8.3 \\
8.3 \\
8.3\end{array}$ & $\begin{array}{l}8.4 \\
8.4 \\
8.4 \\
8.4 \\
8.4\end{array}$ & $\begin{array}{l}8.3 \\
8.4 \\
8.3 \\
8.3 \\
8.3\end{array}$ & $\begin{array}{l}8.4 \\
8.4 \\
8.4 \\
8.3 \\
8.4\end{array}$ & $\begin{array}{l}8.5 \\
8.4 \\
8.4 \\
8.4 \\
8.4\end{array}$ & $\begin{array}{l}8.3 \\
8.3 \\
8.3 \\
8.3 \\
8.3\end{array}$ & $\begin{array}{l}8.4 \\
8.4 \\
8.3 \\
8.3 \\
8.4\end{array}$ & $\begin{array}{r}8.5 \\
8.4 \\
8.4 \\
8.4\end{array}$ & $\begin{array}{r}8.1 \\
8.1 \\
8.3 \\
8.3\end{array}$ & $\begin{array}{r}-- \\
8.2 \\
8.2 \\
8.3 \\
8.3\end{array}$ \\
\hline $\begin{array}{l}16 \\
17 \\
18 \\
19 \\
20\end{array}$ & $\begin{array}{l}8.6 \\
8.6 \\
8.5 \\
8.6 \\
8.6\end{array}$ & $\begin{array}{l}8.3 \\
8.2 \\
8.3 \\
8.2 \\
8.2\end{array}$ & $\begin{array}{l}8.3 \\
8.3 \\
8.3 \\
8.3 \\
8.3\end{array}$ & $\begin{array}{l}8.4 \\
8.1 \\
8.1 \\
8.2 \\
8.3\end{array}$ & $\begin{array}{l}8.1 \\
7.9 \\
8.1 \\
8.1 \\
8.2\end{array}$ & $\begin{array}{l}8.3 \\
8.0 \\
8.1 \\
8.2 \\
8.2\end{array}$ & $\begin{array}{l}8.4 \\
8.4 \\
8.4 \\
8.4 \\
8.4\end{array}$ & $\begin{array}{l}8.3 \\
8.3 \\
8.4 \\
8.3 \\
8.2\end{array}$ & $\begin{array}{l}8.4 \\
8.4 \\
8.4 \\
8.4 \\
8.3\end{array}$ & $\begin{array}{l}8.4 \\
8.4 \\
8.4 \\
8.4 \\
8.4\end{array}$ & $\begin{array}{l}8.3 \\
8.1 \\
8.2 \\
8.3 \\
8.3\end{array}$ & $\begin{array}{l}8.3 \\
8.3 \\
8.4 \\
8.4 \\
8.4\end{array}$ \\
\hline $\begin{array}{l}21 \\
22 \\
23 \\
24 \\
25\end{array}$ & $\begin{array}{r}8.4 \\
8.5 \\
8.4\end{array}$ & $\begin{array}{r}-- \\
8.3 \\
8.4 \\
8.4\end{array}$ & $\begin{array}{r}--- \\
-- \\
8.4 \\
8.4 \\
8.4\end{array}$ & $\begin{array}{l}8.4 \\
8.4 \\
8.4 \\
8.4 \\
8.2\end{array}$ & $\begin{array}{l}8.3 \\
8.4 \\
8.3 \\
8.0 \\
8.1\end{array}$ & $\begin{array}{l}8.3 \\
8.4 \\
8.4 \\
8.1 \\
8.1\end{array}$ & $\begin{array}{l}8.3 \\
8.3 \\
8.4 \\
8.4 \\
8.4\end{array}$ & $\begin{array}{l}8.2 \\
8.3 \\
8.3 \\
8.3 \\
8.3\end{array}$ & $\begin{array}{l}8.3 \\
8.3 \\
8.3 \\
8.3 \\
8.3\end{array}$ & $\begin{array}{l}8.5 \\
8.5 \\
8.5 \\
8.4 \\
8.4\end{array}$ & $\begin{array}{l}8.3 \\
8.3 \\
8.3 \\
8.2 \\
8.1\end{array}$ & $\begin{array}{l}8.4 \\
8.4 \\
8.4 \\
8.3 \\
8.2\end{array}$ \\
\hline $\begin{array}{l}26 \\
27 \\
28 \\
29 \\
30 \\
31\end{array}$ & $\begin{array}{l}8.4 \\
8.4 \\
8.3 \\
8.2 \\
8.3 \\
8.2\end{array}$ & $\begin{array}{l}8.2 \\
8.3 \\
8.2 \\
8.1 \\
8.2 \\
8.1\end{array}$ & $\begin{array}{l}8.4 \\
8.3 \\
8.3 \\
8.2 \\
8.2 \\
8.2\end{array}$ & $\begin{array}{r}8.2 \\
8.3 \\
8.3 \\
8.3 \\
8.2 \\
--\end{array}$ & $\begin{array}{l}8.1 \\
8.2 \\
8.3 \\
8.1 \\
8.1 \\
--\end{array}$ & $\begin{array}{r}8.2 \\
8.3 \\
8.3 \\
8.1 \\
8.1 \\
---\end{array}$ & $\begin{array}{l}8.4 \\
8.4 \\
8.4 \\
8.3 \\
8.3 \\
8.2\end{array}$ & $\begin{array}{l}8.2 \\
8.2 \\
8.2 \\
8.2 \\
8.1 \\
8.1\end{array}$ & $\begin{array}{l}8.3 \\
8.3 \\
8.3 \\
8.2 \\
8.2 \\
8.1\end{array}$ & $\begin{array}{l}8.4 \\
8.4 \\
8.4 \\
8.3 \\
8.3 \\
8.4\end{array}$ & $\begin{array}{l}8.2 \\
8.1 \\
8.2 \\
8.1 \\
8.1 \\
8.1\end{array}$ & $\begin{array}{l}8.2 \\
8.3 \\
8.3 \\
8.2 \\
8.2 \\
8.2\end{array}$ \\
\hline IX & --- & -- & --- & $\begin{array}{l}8.4 \\
8.1\end{array}$ & $\begin{array}{l}8.4 \\
7.9\end{array}$ & $\begin{array}{l}8.4 \\
8.0\end{array}$ & $\begin{array}{l}8.6 \\
8.2\end{array}$ & $\begin{array}{l}8.4 \\
8.1\end{array}$ & $\begin{array}{l}8.5 \\
8.1\end{array}$ & --- & --- & --- \\
\hline
\end{tabular}


07330700 CADDO CREEK SITE 7, COMPARATIVE SAMPLE SITE NEAR GENE AUTRY, OK--Continued

PH, WATER, WHOLE, FIELD, STANDARD UNITS, WATER YEAR OCTOBER 1996 TO SEPTEMBER 1997

\begin{tabular}{|c|c|c|c|c|c|c|c|c|c|c|c|c|}
\hline \multirow[t]{2}{*}{ DAY } & MAX & MIN & MEDIAN & MAX & MIN & MEDIAN & MAX & MIN & MEDIAN & MAX & MIN & MEDIAN \\
\hline & \multicolumn{3}{|c|}{ FEBRUARY } & \multicolumn{3}{|c|}{ MARCH } & \multicolumn{3}{|c|}{ APRIL } & \multicolumn{3}{|c|}{ MAY } \\
\hline $\begin{array}{l}1 \\
2 \\
3 \\
4 \\
5\end{array}$ & $\begin{array}{l}8.4 \\
8.4 \\
8.4 \\
8.5 \\
8.5\end{array}$ & $\begin{array}{l}8.1 \\
8.1 \\
8.1 \\
8.1 \\
8.1\end{array}$ & $\begin{array}{l}8.2 \\
8.2 \\
8.2 \\
8.2 \\
8.2\end{array}$ & $\begin{array}{l}8.2 \\
8.3 \\
8.3 \\
8.4 \\
8.4\end{array}$ & $\begin{array}{l}8.2 \\
8.2 \\
8.3 \\
8.3 \\
8.4\end{array}$ & $\begin{array}{l}8.2 \\
8.3 \\
8.3 \\
8.3 \\
8.4\end{array}$ & $\begin{array}{l}--- \\
--- \\
--- \\
--- \\
8.3\end{array}$ & $\begin{array}{l}--- \\
--- \\
--- \\
-\overline{8.1}\end{array}$ & $\begin{array}{l}--- \\
--- \\
--- \\
--- \\
8.2\end{array}$ & $\begin{array}{l}8.3 \\
8.4 \\
8.4 \\
8.3 \\
8.3\end{array}$ & $\begin{array}{l}8.3 \\
8.3 \\
8.3 \\
8.3 \\
8.3\end{array}$ & $\begin{array}{l}8.3 \\
8.3 \\
8.3 \\
8.3 \\
8.3\end{array}$ \\
\hline $\begin{array}{r}6 \\
7 \\
8 \\
9 \\
10\end{array}$ & $\begin{array}{l}8.2 \\
8.2 \\
8.2 \\
8.3 \\
8.3\end{array}$ & $\begin{array}{l}8.1 \\
8.0 \\
8.2 \\
8.2 \\
8.2\end{array}$ & $\begin{array}{l}8.1 \\
8.1 \\
8.2 \\
8.2 \\
8.3\end{array}$ & $\begin{array}{r}8.6 \\
8.5 \\
8.5\end{array}$ & $\begin{array}{r}-- \\
8.5 \\
8.4 \\
8.4\end{array}$ & $\begin{array}{r}8.5 \\
8.4 \\
8.5\end{array}$ & $\begin{array}{l}8.3 \\
8.4 \\
8.4 \\
8.4 \\
8.4\end{array}$ & $\begin{array}{l}8.2 \\
8.3 \\
8.3 \\
8.3 \\
8.3\end{array}$ & $\begin{array}{l}8.3 \\
8.4 \\
8.3 \\
8.4 \\
8.4\end{array}$ & $\begin{array}{l}8.3 \\
8.4 \\
8.3 \\
8.2 \\
8.0\end{array}$ & $\begin{array}{l}8.2 \\
8.2 \\
8.2 \\
7.8 \\
7.9\end{array}$ & $\begin{array}{l}8.3 \\
8.3 \\
8.2 \\
8.1 \\
8.0\end{array}$ \\
\hline $\begin{array}{l}11 \\
12 \\
13 \\
14 \\
15\end{array}$ & $\begin{array}{l}8.3 \\
8.3 \\
8.4 \\
8.4 \\
8.4\end{array}$ & $\begin{array}{l}8.3 \\
8.3 \\
8.3 \\
8.3 \\
8.3\end{array}$ & $\begin{array}{l}8.3 \\
8.3 \\
8.3 \\
8.4 \\
8.3\end{array}$ & $\begin{array}{l}8.5 \\
8.5 \\
8.4 \\
8.5 \\
8.4\end{array}$ & $\begin{array}{l}8.4 \\
8.4 \\
8.3 \\
8.4 \\
8.4\end{array}$ & $\begin{array}{l}8.4 \\
8.4 \\
8.4 \\
8.4 \\
8.4\end{array}$ & $\begin{array}{l}8.4 \\
8.2 \\
8.2 \\
8.2 \\
8.2\end{array}$ & $\begin{array}{l}7.8 \\
8.0 \\
8.1 \\
8.2 \\
8.1\end{array}$ & $\begin{array}{l}8.0 \\
8.1 \\
8.1 \\
8.2 \\
8.1\end{array}$ & $\begin{array}{l}8.2 \\
8.3 \\
8.3 \\
8.4 \\
8.4\end{array}$ & $\begin{array}{l}8.0 \\
8.2 \\
8.3 \\
8.3 \\
8.3\end{array}$ & $\begin{array}{l}8.1 \\
8.2 \\
8.3 \\
8.3 \\
8.3\end{array}$ \\
\hline $\begin{array}{l}16 \\
17 \\
18 \\
19 \\
20\end{array}$ & $\begin{array}{r}8.4 \\
8.4 \\
8.5 \\
8.4 \\
---\end{array}$ & $\begin{array}{r}8.3 \\
8.3 \\
8.3 \\
8.1 \\
--\end{array}$ & $\begin{array}{r}8.3 \\
8.4 \\
8.4 \\
8.3 \\
---\end{array}$ & $\begin{array}{r}8.4 \\
8.4 \\
8.3 \\
--- \\
---\end{array}$ & $\begin{array}{c}8.4 \\
8.3 \\
8.3 \\
--- \\
---\end{array}$ & $\begin{array}{c}8.4 \\
8.3 \\
8.3 \\
--- \\
---\end{array}$ & $\begin{array}{l}8.2 \\
8.2 \\
8.3 \\
8.3 \\
8.4\end{array}$ & $\begin{array}{l}8.1 \\
8.2 \\
8.2 \\
8.2 \\
8.2\end{array}$ & $\begin{array}{l}8.2 \\
8.2 \\
8.2 \\
8.2 \\
8.3\end{array}$ & $\begin{array}{l}8.4 \\
8.4 \\
8.4 \\
8.2 \\
8.0\end{array}$ & $\begin{array}{l}8.3 \\
8.2 \\
8.2 \\
7.7 \\
7.8\end{array}$ & $\begin{array}{l}8.3 \\
8.3 \\
8.3 \\
7.9 \\
7.9\end{array}$ \\
\hline $\begin{array}{l}21 \\
22 \\
23 \\
24 \\
25\end{array}$ & $\begin{array}{l}8.1 \\
8.1 \\
8.1 \\
8.1 \\
8.1\end{array}$ & $\begin{array}{l}8.0 \\
8.0 \\
8.0 \\
8.1 \\
8.1\end{array}$ & $\begin{array}{l}8.0 \\
8.1 \\
8.1 \\
8.1 \\
8.1\end{array}$ & $\begin{array}{l}--- \\
--- \\
--- \\
--- \\
---\end{array}$ & $\begin{array}{l}--- \\
--- \\
--- \\
--- \\
---\end{array}$ & $\begin{array}{l}--- \\
--- \\
--- \\
--- \\
---\end{array}$ & $\begin{array}{l}8.3 \\
8.3 \\
8.3 \\
8.4 \\
8.4\end{array}$ & $\begin{array}{l}8.2 \\
8.3 \\
8.3 \\
8.3 \\
7.9\end{array}$ & $\begin{array}{l}8.3 \\
8.3 \\
8.3 \\
8.4 \\
8.3\end{array}$ & $\begin{array}{l}8.1 \\
8.2 \\
8.2 \\
8.3 \\
8.3\end{array}$ & $\begin{array}{l}8.0 \\
8.1 \\
8.2 \\
8.2 \\
8.2\end{array}$ & $\begin{array}{l}8.1 \\
8.1 \\
8.2 \\
8.2 \\
8.3\end{array}$ \\
\hline $\begin{array}{l}26 \\
27 \\
28 \\
29 \\
30 \\
31\end{array}$ & $\begin{array}{r}8.1 \\
8.2 \\
8.2 \\
--- \\
--- \\
---\end{array}$ & $\begin{array}{c}8.0 \\
8.0 \\
8.2 \\
--- \\
--- \\
--\end{array}$ & $\begin{array}{c}8.1 \\
8.1 \\
8.2 \\
--- \\
--- \\
---\end{array}$ & $\begin{array}{l}--- \\
--- \\
--- \\
--- \\
--- \\
---\end{array}$ & $\begin{array}{l}--- \\
--- \\
--- \\
--- \\
--- \\
---\end{array}$ & $\begin{array}{l}--- \\
--- \\
--- \\
--- \\
--- \\
---\end{array}$ & $\begin{array}{r}8.1 \\
8.1 \\
8.2 \\
8.2 \\
8.3 \\
---\end{array}$ & $\begin{array}{r}7.9 \\
8.1 \\
8.1 \\
8.2 \\
8.2 \\
--\end{array}$ & $\begin{array}{r}8.0 \\
8.1 \\
8.2 \\
8.2 \\
8.3 \\
---\end{array}$ & $\begin{array}{l}8.3 \\
8.3 \\
8.4 \\
8.4 \\
8.4 \\
8.0\end{array}$ & $\begin{array}{l}8.2 \\
8.2 \\
8.3 \\
8.3 \\
7.8 \\
7.9\end{array}$ & $\begin{array}{l}8.3 \\
8.2 \\
8.3 \\
8.4 \\
8.0 \\
7.9\end{array}$ \\
\hline $\begin{array}{l}\text { MAX } \\
\text { MIN }\end{array}$ & --- & $\begin{array}{l}--- \\
---\end{array}$ & --- & --- & $\begin{array}{l}--- \\
---\end{array}$ & $=-$ & -- & --- & --- & $\begin{array}{l}8.4 \\
8.0\end{array}$ & $\begin{array}{l}8.3 \\
7.7\end{array}$ & $\begin{array}{l}8.4 \\
7.9\end{array}$ \\
\hline
\end{tabular}


07330700 CADDO CREEK SITE 7, COMPARATIVE SAMPLE SITE NEAR GENE AUTRY, OK--Continued

PH, WATER, WHOLE, FIELD, STANDARD UNITS, WATER YEAR OCTOBER 1996 TO SEPTEMBER 1997

\begin{tabular}{|c|c|c|c|c|c|c|c|c|c|c|c|c|}
\hline \multirow[t]{2}{*}{ DAY } & MAX & MIN & MEDIAN & MAX & MIN & MEDIAN & MAX & MIN & MEDIAN & MAX & MIN & MEDIAN \\
\hline & \multicolumn{3}{|c|}{ JUNE } & \multicolumn{3}{|c|}{ JULY } & \multicolumn{3}{|c|}{ AUGUST } & \multicolumn{3}{|c|}{ SEPTEMBER } \\
\hline 1 & 8.0 & 7.9 & 8.0 & 8.3 & 7.9 & 8.1 & 8.4 & 7.8 & 8.0 & --- & -- & --- \\
\hline 2 & 8.1 & 8.0 & 8.1 & 8.3 & 8.0 & 8.1 & 8.5 & 7.7 & 8.0 & --- & -- & -- \\
\hline 3 & 8.2 & 8.1 & 8.1 & 8.3 & 7.9 & 8.0 & 8.5 & 7.6 & 8.0 & --- & --- & -- \\
\hline 4 & 8.2 & 8.2 & 8.2 & 8.3 & 8.0 & 8.1 & 8.5 & 7.6 & 8.0 & -- & --- & -- \\
\hline 5 & 8.3 & 8.2 & 8.3 & 8.2 & 7.8 & 7.9 & 8.3 & 7.7 & 8.0 & --- & -- & --- \\
\hline 6 & 8.3 & 8.3 & 8.3 & 8.3 & 7.7 & 7.9 & 8.2 & 7.6 & 7.9 & $-\cdots$ & -- & -- \\
\hline 7 & 8.4 & 8.3 & 8.3 & 8.3 & 7.8 & 8.0 & 7.9 & 7.8 & 7.8 & -- & -- &.- \\
\hline 8 & 8.4 & 8.3 & 8.3 & 8.5 & 7.9 & 8.2 & 8.0 & 7.6 & 7.7 & -- & $\cdots$ & -- \\
\hline 9 & 8.4 & 7.9 & 8.3 & --- & --- & --- & 8.1 & 7.4 & 7.8 &.- & -- & -- \\
\hline 10 & 8.0 & 7.8 & 7.9 & -.- & -- & $\cdots$ & 8.1 & 7.5 & 7.7 & --- & -- & -- \\
\hline 11 & 7.9 & 7.9 & 7.9 & --- & --- & -- & 8.0 & 7.4 & 7.6 & -- & --- & -- \\
\hline 12 & 8.1 & 7.9 & 8.1 & $\cdots$ & --- & --- & -- & -- & --- & --- & --- & -- \\
\hline 13 & 8.2 & 8.0 & 8.2 & --- & --- & --- & --- & -- & --- & -- & --- & --- \\
\hline 14 & 8.2 & 8.1 & 8.2 & $\cdots$ & --- & --- & --- & --- & -- & $\cdots$ & --- & --- \\
\hline 15 & 8.3 & 8.2 & 8.3 & $\cdots$ & -- & -- & --- & -- & --- & -- & --- & -- \\
\hline 16 & 8.3 & 8.3 & 8.3 & -- & --- & -- & -- & --- & -- & -.. & $\ldots$ & -.- \\
\hline 17 & 8.4 & 8.3 & 8.4 & --- & -- & --- & -- & -- & --- & -- & --- & -- \\
\hline 18 & 8.7 & 8.2 & 8.2 & $\cdots$ & $\cdots$ & -- & -- & -- & -- & -- & --- & --- \\
\hline 19 & 8.3 & 8.2 & 8.3 & 8.4 & 7.9 & 8.0 & --- & --- & --- & -.- & -- & -- \\
\hline 20 & 8.4 & 8.3 & 8.3 & 8.5 & 7.7 & 8.0 & --- & $\cdots$ & --- & --- & --- & -- \\
\hline 21 & 8.4 & 8.2 & 8.4 & 8.6 & 7.7 & 8.0 & $\cdots$ & -- & $\cdots$ & -- & --- & -- \\
\hline 22 & 8.3 & 8.2 & 8.2 & 8.4 & 7.7 & 8.0 & --- & -- & --- & -- & --- & -- \\
\hline 23 & 8.2 & 8.0 & 8.2 & --- & --- & -- & --- & -- & -- & -- & -- & -- \\
\hline 24 & 8.2 & 8.1 & 8.2 & -- & -- & -- & -- & -- & -- & $\cdots$ & --- & -- \\
\hline 25 & --- & -- & --- & --- & --- & --- & $\cdots$ & -- & -- & -- & -- & -- \\
\hline 26 & --- & --- & -- & 8.4 & 7.8 & 8.0 & --- & -- & --- & --- & --- & --- \\
\hline 27 & 8.1 & 8.0 & 8.0 & --- & --- & --- & -- & -- & --- & --- & --- & -- \\
\hline 28 & 8.1 & 7.9 & 8.0 & -.- & $-\cdots$ & $\cdots$ & -- & $\cdots$ & --- & -- & --- & -- \\
\hline 29 & 8.2 & 7.9 & 8.0 & $\cdots$ & -- & --- & --- & -- & --- & --- & --- & -- \\
\hline 30 & 8.2 & 7.9 & 8.0 & --- & --- & --- & --- & -- & --- & -- & --- & -- \\
\hline 31 & --- & -- & $\cdots$ & 8.3 & 7.7 & 8.0 & -.- & -- & -- & $\cdots$ & --- & $\cdots$ \\
\hline & -.- & -- & --- & --- & -- & -.- & --- & $\ldots$ & --- & -- & -- & -- \\
\hline & & & & - & - & $\cdots$ & - & - & --- & $\cdots$ & & 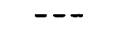 \\
\hline
\end{tabular}


07330700 CADDO CREEK SITE 7, COMPARATIVE SAMPLE SITE NEAR GENE AUTRY, OK--Continued

WATER TEMPERATURE, DEGREES CELSIUS, WATER YEAR OCTOBER 1996 TO SEPTEMBER 1997

\begin{tabular}{|c|c|c|c|c|c|c|c|c|c|c|c|c|}
\hline \multirow{2}{*}{ DAY } & MAX & MIN & MEAN & MAX & MIN & MEAN & MAX & MIN & MEAN & MAX & MIN & MEAN \\
\hline & \multicolumn{3}{|c|}{ OCTOBER } & \multicolumn{3}{|c|}{ NOVEMBER } & \multicolumn{3}{|c|}{ DECEMBER } & \multicolumn{3}{|c|}{ JANUARY } \\
\hline $\begin{array}{l}1 \\
2 \\
3 \\
4 \\
5\end{array}$ & $\begin{array}{l}21.0 \\
22.0 \\
25.0 \\
-- \\
---\end{array}$ & $\begin{array}{l}18.5 \\
19.0 \\
20.5 \\
-\ldots \\
--\end{array}$ & $\begin{array}{l}20.0 \\
20.5 \\
21.5 \\
--- \\
---\end{array}$ & $\begin{array}{l}14.5 \\
12.5 \\
12.0 \\
14.0 \\
16.0\end{array}$ & $\begin{array}{l}11.5 \\
10.0 \\
10.0 \\
11.5 \\
12.5\end{array}$ & $\begin{array}{l}13.0 \\
11.5 \\
11.0 \\
12.5 \\
14.5\end{array}$ & $\begin{array}{l}8.5 \\
8.5 \\
8.5 \\
8.0 \\
8.5\end{array}$ & $\begin{array}{l}7.5 \\
7.0 \\
7.5 \\
6.5 \\
7.0\end{array}$ & $\begin{array}{l}8.0 \\
8.0 \\
8.0 \\
7.5 \\
8.0\end{array}$ & $\begin{array}{l}13.0 \\
14.5 \\
16.5 \\
16.0 \\
13.5\end{array}$ & $\begin{array}{l}12.0 \\
12.0 \\
13.5 \\
13.5 \\
10.0\end{array}$ & $\begin{array}{l}12.5 \\
13.0 \\
14.5 \\
15.0 \\
11.5\end{array}$ \\
\hline $\begin{array}{l}6 \\
7 \\
8\end{array}$ & $\begin{array}{l}--- \\
--- \\
--- \\
21.0 \\
20.0\end{array}$ & $\begin{array}{l}--- \\
--- \\
-- \\
17.5 \\
17.0\end{array}$ & $\begin{array}{l}--- \\
--- \\
--- \\
19.0 \\
18.5\end{array}$ & $\begin{array}{l}19.0 \\
16.5 \\
13.5 \\
12.0 \\
12.0\end{array}$ & $\begin{array}{l}16.0 \\
13.0 \\
11.5 \\
10.0 \\
10.5\end{array}$ & $\begin{array}{l}17.5 \\
14.0 \\
12.0 \\
11.0 \\
11.5\end{array}$ & $\begin{array}{r}9.5 \\
9.5 \\
9.0 \\
9.5 \\
12.5\end{array}$ & $\begin{array}{l}8.0 \\
8.5 \\
7.5 \\
7.5 \\
9.5\end{array}$ & $\begin{array}{r}9.0 \\
9.0 \\
8.5 \\
8.5 \\
11.0\end{array}$ & $\begin{array}{c}10.0 \\
6.5 \\
--- \\
--- \\
---\end{array}$ & $\begin{array}{c}6.5 \\
5.0 \\
--- \\
---\end{array}$ & $\begin{array}{r}8.0 \\
5.5 \\
--- \\
--- \\
---\end{array}$ \\
\hline & $\begin{array}{l}20.0 \\
21.5 \\
22.5 \\
22.5 \\
22.5\end{array}$ & $\begin{array}{l}17.0 \\
17.5 \\
18.5 \\
18.0 \\
18.5\end{array}$ & $\begin{array}{l}18.0 \\
19.0 \\
20.0 \\
20.0 \\
20.5\end{array}$ & $\begin{array}{l}12.0 \\
12.0 \\
12.5 \\
15.5 \\
15.5\end{array}$ & $\begin{array}{l}10.5 \\
11.0 \\
10.5 \\
12.5 \\
15.0\end{array}$ & $\begin{array}{l}11.5 \\
11.5 \\
11.5 \\
14.0 \\
15.0\end{array}$ & $\begin{array}{l}12.5 \\
12.0 \\
12.0 \\
12.5 \\
12.0\end{array}$ & $\begin{array}{r}11.5 \\
10.5 \\
9.5 \\
10.5 \\
8.5\end{array}$ & $\begin{array}{l}12.0 \\
11.0 \\
10.5 \\
11.5 \\
10.0\end{array}$ & $\begin{array}{r}- \\
2.0 \\
1.0 \\
1.5 \\
3.5\end{array}$ & $\begin{array}{r}.5 \\
.5 \\
.5 \\
1.0\end{array}$ & $\begin{array}{r}-- \\
1.0 \\
1.0 \\
1.0 \\
2.0\end{array}$ \\
\hline & $\begin{array}{l}24.5 \\
22.5 \\
19.0 \\
16.5 \\
19.5\end{array}$ & $\begin{array}{l}20.0 \\
19.0 \\
15.5 \\
13.5 \\
15.0\end{array}$ & $\begin{array}{l}22.0 \\
21.5 \\
17.0 \\
15.0 \\
17.0\end{array}$ & $\begin{array}{l}17.5 \\
16.0 \\
12.5 \\
14.0 \\
15.5\end{array}$ & $\begin{array}{l}15.0 \\
12.5 \\
11.5 \\
11.5 \\
14.0\end{array}$ & $\begin{array}{l}15.5 \\
14.5 \\
12.0 \\
12.5 \\
14.5\end{array}$ & $\begin{array}{l}8.5 \\
7.0 \\
3.5 \\
1.5 \\
2.0\end{array}$ & $\begin{array}{r}6.5 \\
3.5 \\
1.5 \\
.0 \\
.5\end{array}$ & $\begin{array}{l}7.0 \\
5.5 \\
2.5 \\
1.0 \\
1.0\end{array}$ & $\begin{array}{l}3.0 \\
2.0 \\
1.5 \\
3.5 \\
7.5\end{array}$ & $\begin{array}{r}1.0 \\
.5 \\
.5 \\
.5 \\
2.5\end{array}$ & $\begin{array}{l}2.0 \\
1.0 \\
1.0 \\
2.0 \\
5.0\end{array}$ \\
\hline & $\begin{array}{l}--- \\
15.0 \\
15.0 \\
--- \\
---\end{array}$ & $\begin{array}{l}\cdots \\
13.5 \\
11.0 \\
\cdots-\end{array}$ & $\begin{array}{l}--- \\
16.0 \\
13.5 \\
--- \\
---\end{array}$ & $\begin{array}{r}15.0 \\
13.0 \\
14.0 \\
13.5 \\
7.5\end{array}$ & $\begin{array}{r}13.0 \\
12.0 \\
13.0 \\
7.5 \\
6.5\end{array}$ & $\begin{array}{r}14.5 \\
12.5 \\
13.5 \\
9.0 \\
6.5\end{array}$ & $\begin{array}{r}6.0 \\
9.5 \\
11.5 \\
8.0 \\
5.0\end{array}$ & $\begin{array}{l}1.5 \\
6.0 \\
8.0 \\
4.0 \\
2.5\end{array}$ & $\begin{array}{r}3.5 \\
7.5 \\
10.0 \\
5.5 \\
3.5\end{array}$ & $\begin{array}{r}11.5 \\
11.5 \\
11.0 \\
11.5 \\
9.5\end{array}$ & $\begin{array}{l}7.5 \\
9.0 \\
9.0 \\
9.5 \\
7.5\end{array}$ & $\begin{array}{r}9.5 \\
10.5 \\
10.0 \\
10.5 \\
8.5\end{array}$ \\
\hline & $\begin{array}{l}--- \\
--- \\
--- \\
--- \\
-- \\
17.0\end{array}$ & $\begin{array}{l}--- \\
--- \\
--- \\
--- \\
--- \\
14.5\end{array}$ & $\begin{array}{l}--- \\
--- \\
--- \\
--- \\
--- \\
15.5\end{array}$ & $\begin{array}{r}6.5 \\
7.0 \\
7.5 \\
7.5 \\
8.5 \\
---\end{array}$ & $\begin{array}{r}6.0 \\
6.0 \\
6.5 \\
6.5 \\
7.0 \\
--\end{array}$ & $\begin{array}{r}6.5 \\
6.5 \\
7.0 \\
7.0 \\
8.0 \\
--\end{array}$ & $\begin{array}{r}6.0 \\
7.0 \\
8.0 \\
8.5 \\
11.0 \\
12.5\end{array}$ & $\begin{array}{r}5.0 \\
5.0 \\
6.5 \\
6.5 \\
8.0 \\
11.0\end{array}$ & $\begin{array}{r}5.5 \\
6.0 \\
7.0 \\
7.5 \\
9.0 \\
11.5\end{array}$ & $\begin{array}{r}10.5 \\
11.0 \\
6.0 \\
4.5 \\
6.0 \\
8.5\end{array}$ & $\begin{array}{l}7.5 \\
6.0 \\
2.5 \\
1.0 \\
2.0 \\
4.0\end{array}$ & $\begin{array}{l}9.0 \\
9.5 \\
3.5 \\
2.5 \\
3.5 \\
6.0\end{array}$ \\
\hline
\end{tabular}

MONTH

19.0

6.0

11.7

12.5

.0 
07330700 CADDO CREEK SITE 7, COMPARATIVE SAMPLE SITE NEAR GENE AUTRY, OK--Continued

WATER TEMPERATURE, DEGREES CELSIUS, WATER YEAR OCTOBER 1996 TO SEPTEMBER 1997

\begin{tabular}{|c|c|c|c|c|c|c|c|c|c|c|c|c|}
\hline \multirow[t]{2}{*}{ DAY } & MAX & MIN & MEAN & MAX & MIN & MEAN & $\operatorname{MAX}$ & MIN & MEAN & MAX & MIN & MEAN \\
\hline & \multicolumn{3}{|c|}{ FEBRUARY } & \multicolumn{3}{|c|}{ MARCH } & \multicolumn{3}{|c|}{ APRIL } & \multicolumn{3}{|c|}{ MAY } \\
\hline $\begin{array}{l}1 \\
2 \\
3 \\
4 \\
5\end{array}$ & $\begin{array}{r}10.0 \\
11.5 \\
12.0 \\
11.5 \\
9.5\end{array}$ & $\begin{array}{r}6.5 \\
8.5 \\
10.0 \\
9.5 \\
8.0\end{array}$ & $\begin{array}{r}8.0 \\
9.5 \\
10.5 \\
10.5 \\
8.5\end{array}$ & $\begin{array}{r}-- \\
12.5 \\
12.0 \\
13.0 \\
14.5\end{array}$ & $\begin{array}{r}10.5 \\
9.0 \\
11.0 \\
12.5\end{array}$ & $\begin{array}{l}-\overline{11.5} \\
10.5 \\
12.0 \\
13.5\end{array}$ & $\begin{array}{l}--- \\
--- \\
--- \\
-- \\
23.5\end{array}$ & $\begin{array}{l}--- \\
--- \\
--- \\
--- \\
17.0\end{array}$ & $\begin{array}{l}--- \\
--- \\
--- \\
--- \\
18.5\end{array}$ & $\begin{array}{l}21.5 \\
24.0 \\
22.5 \\
22.5 \\
24.0\end{array}$ & $\begin{array}{l}18.5 \\
18.0 \\
18.5 \\
18.0 \\
19.5\end{array}$ & $\begin{array}{l}20.0 \\
21.0 \\
21.0 \\
20.5 \\
21.5\end{array}$ \\
\hline $\begin{array}{r}6 \\
7 \\
8 \\
9 \\
10\end{array}$ & $\begin{array}{l}9.5 \\
8.5 \\
6.5 \\
5.5 \\
6.5\end{array}$ & $\begin{array}{l}8.5 \\
6.5 \\
5.5 \\
5.0 \\
5.0\end{array}$ & $\begin{array}{l}8.5 \\
7.5 \\
6.0 \\
5.5 \\
6.0\end{array}$ & $\begin{array}{l}--- \\
--- \\
12.0 \\
15.0 \\
15.5\end{array}$ & $\begin{array}{l}--- \\
--\overline{11.0} \\
12.0 \\
13.0\end{array}$ & $\begin{array}{l}--- \\
-- \\
11.5 \\
13.5 \\
14.5\end{array}$ & $\begin{array}{l}18.5 \\
17.5 \\
17.0 \\
15.0 \\
17.5\end{array}$ & $\begin{array}{l}16.0 \\
14.5 \\
15.0 \\
13.0 \\
13.0\end{array}$ & $\begin{array}{l}17.0 \\
16.0 \\
16.0 \\
14.0 \\
15.5\end{array}$ & $\begin{array}{l}26.0 \\
25.5 \\
24.5 \\
23.5 \\
21.0\end{array}$ & $\begin{array}{l}21.5 \\
22.5 \\
22.5 \\
19.5 \\
18.0\end{array}$ & $\begin{array}{l}23.5 \\
24.0 \\
23.5 \\
21.0 \\
19.5\end{array}$ \\
\hline $\begin{array}{l}11 \\
12 \\
13 \\
14 \\
15\end{array}$ & $\begin{array}{r}8.5 \\
8.5 \\
7.0 \\
9.0 \\
10.0\end{array}$ & $\begin{array}{l}4.5 \\
7.0 \\
6.5 \\
6.0 \\
6.0\end{array}$ & $\begin{array}{l}6.5 \\
8.0 \\
7.0 \\
7.5 \\
8.0\end{array}$ & $\begin{array}{l}17.0 \\
16.0 \\
-- \\
14.5 \\
11.5\end{array}$ & $\begin{array}{r}13.5 \\
14.0 \\
-11.5 \\
11.5 \\
6.5\end{array}$ & $\begin{array}{r}15.0 \\
15.0 \\
-12.5 \\
8.5\end{array}$ & $\begin{array}{l}17.5 \\
14.5 \\
13.0 \\
14.5 \\
16.5\end{array}$ & $\begin{array}{l}12.5 \\
11.0 \\
10.5 \\
11.5 \\
12.5\end{array}$ & $\begin{array}{l}14.5 \\
11.5 \\
11.5 \\
13.0 \\
14.5\end{array}$ & $\begin{array}{l}22.0 \\
21.5 \\
21.5 \\
21.5 \\
23.0\end{array}$ & $\begin{array}{l}18.5 \\
18.0 \\
16.0 \\
19.5 \\
19.0\end{array}$ & $\begin{array}{l}20.0 \\
19.5 \\
18.5 \\
20.5 \\
21.0\end{array}$ \\
\hline $\begin{array}{l}16 \\
17 \\
18 \\
19 \\
20\end{array}$ & $\begin{array}{l}11.5 \\
12.5 \\
13.0 \\
14.0 \\
---\end{array}$ & $\begin{array}{r}7.0 \\
8.0 \\
10.0 \\
12.5 \\
--\end{array}$ & $\begin{array}{r}9.5 \\
10.5 \\
11.5 \\
13.5 \\
---\end{array}$ & $\begin{array}{l}10.0 \\
12.5 \\
14.0 \\
--- \\
--\end{array}$ & $\begin{array}{r}7.5 \\
9.5 \\
12.5 \\
-.- \\
--\end{array}$ & $\begin{array}{r}9.0 \\
10.5 \\
13.0 \\
-- \\
--\end{array}$ & $\begin{array}{l}18.0 \\
19.5 \\
19.0 \\
21.5 \\
22.5\end{array}$ & $\begin{array}{l}15.0 \\
16.0 \\
16.5 \\
17.0 \\
19.0\end{array}$ & $\begin{array}{l}16.5 \\
18.0 \\
18.0 \\
19.0 \\
20.5\end{array}$ & $\begin{array}{l}25.5 \\
27.5 \\
28.5 \\
26.5 \\
21.0\end{array}$ & $\begin{array}{l}20.0 \\
21.5 \\
23.0 \\
20.0 \\
19.5\end{array}$ & $\begin{array}{l}22.5 \\
24.0 \\
25.5 \\
22.5 \\
20.0\end{array}$ \\
\hline $\begin{array}{l}21 \\
22 \\
23 \\
24 \\
25\end{array}$ & $\begin{array}{l}13.5 \\
11.5 \\
11.5 \\
11.5 \\
11.5\end{array}$ & $\begin{array}{l}11.5 \\
10.5 \\
11.0 \\
11.0 \\
11.0\end{array}$ & $\begin{array}{l}12.5 \\
11.0 \\
11.0 \\
11.5 \\
11.0\end{array}$ & $\begin{array}{l}--- \\
--- \\
--- \\
---\end{array}$ & $\begin{array}{l}--- \\
--- \\
--- \\
--- \\
---\end{array}$ & $\begin{array}{l}--- \\
--- \\
--- \\
--- \\
---\end{array}$ & $\begin{array}{l}23.0 \\
23.5 \\
22.0 \\
20.5 \\
17.5\end{array}$ & $\begin{array}{l}20.0 \\
20.0 \\
19.5 \\
17.5 \\
15.0\end{array}$ & $\begin{array}{l}21.5 \\
22.0 \\
21.0 \\
19.0 \\
16.0\end{array}$ & $\begin{array}{l}20.0 \\
22.5 \\
22.5 \\
25.0 \\
26.5\end{array}$ & $\begin{array}{l}19.0 \\
19.5 \\
21.0 \\
22.0 \\
24.0\end{array}$ & $\begin{array}{l}19.5 \\
21.0 \\
22.0 \\
23.5 \\
25.0\end{array}$ \\
\hline $\begin{array}{l}26 \\
27 \\
28 \\
29 \\
30 \\
31\end{array}$ & $\begin{array}{l}11.0 \\
10.5 \\
11.0 \\
-- \\
-- \\
--\end{array}$ & $\begin{array}{r}9.5 \\
9.0 \\
10.0 \\
-- \\
-- \\
--\end{array}$ & $\begin{array}{r}10.5 \\
9.5 \\
10.5 \\
-- \\
-- \\
---\end{array}$ & $\begin{array}{l}--- \\
--- \\
--- \\
--- \\
--- \\
---\end{array}$ & $\begin{array}{l}--- \\
--- \\
--- \\
--- \\
--- \\
---\end{array}$ & $\begin{array}{l}--- \\
--- \\
--- \\
--- \\
--- \\
---\end{array}$ & $\begin{array}{l}15.5 \\
17.5 \\
21.0 \\
21.0 \\
22.0 \\
---\end{array}$ & $\begin{array}{l}15.0 \\
15.5 \\
17.0 \\
17.0 \\
16.0 \\
--\end{array}$ & $\begin{array}{r}15.5 \\
16.5 \\
18.5 \\
20.0 \\
19.5 \\
---\end{array}$ & $\begin{array}{l}29.0 \\
28.5 \\
27.0 \\
26.5 \\
25.5 \\
24.0\end{array}$ & $\begin{array}{l}25.0 \\
26.0 \\
24.0 \\
23.5 \\
21.0 \\
20.0\end{array}$ & $\begin{array}{l}27.0 \\
27.0 \\
25.5 \\
25.0 \\
23.5 \\
22.0\end{array}$ \\
\hline $\mathrm{JTH}$ & -- & -- & --- & -- & --- & --- & -- & --- & --- & 29.0 & 16.0 & 22.3 \\
\hline
\end{tabular}


07330700 CADDO CREEK SITE 7, COMPARATIVE SAMPLE SITE NEAR GENE AUTRY, OK--Continued

WATER TEMPERATURE, DEGREES CELSIUS, WATER YEAR OCTOBER 1996 TO SEPTEMBER 1997

\begin{tabular}{|c|c|c|c|c|c|c|c|c|c|c|c|c|}
\hline \multirow[t]{2}{*}{ DAY } & MAX & MIN & MEAN & MAX & MIN & MEAN & MAX & MIN & MEAN & MAX & MIN & MEAN \\
\hline & \multicolumn{3}{|c|}{ JUNE } & \multicolumn{3}{|c|}{ JULY } & \multicolumn{3}{|c|}{ AUGUST } & \multicolumn{3}{|c|}{ SEPTEMBER } \\
\hline $\begin{array}{l}1 \\
2 \\
3 \\
4 \\
5\end{array}$ & $\begin{array}{l}24.5 \\
25.0 \\
24.5 \\
25.5 \\
25.5\end{array}$ & $\begin{array}{l}21.5 \\
23.0 \\
23.0 \\
23.0 \\
23.0\end{array}$ & $\begin{array}{l}23.0 \\
24.0 \\
24.0 \\
24.0 \\
24.0\end{array}$ & $\begin{array}{l}33.0 \\
34.5 \\
36.0 \\
32.5 \\
28.5\end{array}$ & $\begin{array}{l}26.5 \\
27.5 \\
30.5 \\
25.0 \\
25.0\end{array}$ & $\begin{array}{l}30.0 \\
30.5 \\
32.5 \\
29.5 \\
26.5\end{array}$ & $\begin{array}{l}31.5 \\
31.0 \\
31.5 \\
29.5 \\
31.5\end{array}$ & $\begin{array}{l}26.0 \\
25.5 \\
25.5 \\
25.5 \\
24.0\end{array}$ & $\begin{array}{l}28.5 \\
28.0 \\
28.5 \\
28.0 \\
28.0\end{array}$ & $\begin{array}{l}31.5 \\
29.5 \\
30.0 \\
28.5 \\
30.0\end{array}$ & $\begin{array}{l}24.5 \\
25.5 \\
25.5 \\
26.5 \\
24.5\end{array}$ & $\begin{array}{l}28.5 \\
27.5 \\
27.5 \\
27.5 \\
27.0\end{array}$ \\
\hline $\begin{array}{r}6 \\
7 \\
8 \\
9 \\
10\end{array}$ & $\begin{array}{l}25.5 \\
25.0 \\
23.5 \\
26.0 \\
21.5\end{array}$ & $\begin{array}{l}23.0 \\
21.5 \\
22.0 \\
16.5 \\
20.0\end{array}$ & $\begin{array}{l}24.0 \\
23.5 \\
23.0 \\
23.0 \\
21.0\end{array}$ & $\begin{array}{l}29.5 \\
29.0 \\
--- \\
--- \\
--\end{array}$ & $\begin{array}{l}25.0 \\
25.5 \\
--- \\
--- \\
---\end{array}$ & $\begin{array}{l}26.5 \\
27.0 \\
-- \\
-- \\
--\end{array}$ & $\begin{array}{l}29.5 \\
25.5 \\
23.0 \\
29.0 \\
30.0\end{array}$ & $\begin{array}{l}24.5 \\
20.5 \\
20.5 \\
20.0 \\
24.5\end{array}$ & $\begin{array}{l}26.0 \\
22.5 \\
21.5 \\
24.0 \\
26.5\end{array}$ & $\begin{array}{l}29.0 \\
30.5 \\
30.0 \\
29.0 \\
27.5\end{array}$ & $\begin{array}{l}24.0 \\
24.0 \\
25.5 \\
25.5 \\
23.5\end{array}$ & $\begin{array}{l}26.5 \\
27.0 \\
27.5 \\
27.0 \\
25.5\end{array}$ \\
\hline $\begin{array}{l}11 \\
12 \\
13 \\
14 \\
15\end{array}$ & $\begin{array}{l}24.5 \\
27.5 \\
28.5 \\
29.0 \\
28.5\end{array}$ & $\begin{array}{l}20.0 \\
20.0 \\
26.0 \\
26.0 \\
27.0\end{array}$ & $\begin{array}{l}22.5 \\
24.0 \\
27.5 \\
28.0 \\
28.0\end{array}$ & $\begin{array}{l}--- \\
--- \\
--- \\
--- \\
---\end{array}$ & $\begin{array}{l}--- \\
--- \\
--- \\
--- \\
---\end{array}$ & $\begin{array}{l}--- \\
--- \\
--- \\
--- \\
---\end{array}$ & $\begin{array}{l}28.5 \\
--- \\
--- \\
-- \\
---\end{array}$ & $\begin{array}{l}26.0 \\
-- \\
\cdots- \\
\cdots- \\
\cdots-\end{array}$ & $\begin{array}{l}27.0 \\
--- \\
--- \\
--- \\
---\end{array}$ & $\begin{array}{l}27.0 \\
27.5 \\
29.5 \\
30.0 \\
29.5\end{array}$ & $\begin{array}{l}21.5 \\
22.5 \\
25.0 \\
26.5 \\
26.0\end{array}$ & $\begin{array}{l}24.5 \\
24.5 \\
27.0 \\
28.0 \\
27.5\end{array}$ \\
\hline $\begin{array}{l}16 \\
17 \\
18 \\
19 \\
20\end{array}$ & $\begin{array}{r}29.5 \\
29.5 \\
29.0 \\
30.5 \\
---\end{array}$ & $\begin{array}{r}25.5 \\
27.0 \\
25.0 \\
26.0 \\
--\end{array}$ & $\begin{array}{r}27.5 \\
28.5 \\
27.5 \\
28.0 \\
---\end{array}$ & $\begin{array}{l}--- \\
--- \\
--- \\
31.5 \\
32.5\end{array}$ & $\begin{array}{r}\cdots \\
-\cdots \\
-- \\
27.0 \\
26.5\end{array}$ & $\begin{array}{r}-\cdots \\
-\cdots \\
-- \\
29.0 \\
29.0\end{array}$ & $\begin{array}{r}32.0 \\
30.5 \\
31.0 \\
30.5 \\
--\end{array}$ & $\begin{array}{r}26.5 \\
27.0 \\
27.0 \\
27.5 \\
--\end{array}$ & $\begin{array}{l}30.5 \\
28.5 \\
29.0 \\
29.0 \\
---\end{array}$ & $\begin{array}{l}--- \\
--- \\
--- \\
--- \\
---\end{array}$ & $\begin{array}{l}--- \\
--- \\
--- \\
--- \\
---\end{array}$ & $\begin{array}{l}--- \\
--- \\
--- \\
--- \\
---\end{array}$ \\
\hline $\begin{array}{l}21 \\
22 \\
23 \\
24 \\
25\end{array}$ & $\begin{array}{l}--- \\
--- \\
--- \\
--- \\
---\end{array}$ & $\begin{array}{l}--- \\
--- \\
--- \\
--- \\
---\end{array}$ & $\begin{array}{l}--- \\
--- \\
--- \\
--- \\
---\end{array}$ & $\begin{array}{c}32.5 \\
31.0 \\
-- \\
-- \\
--\end{array}$ & $\begin{array}{l}27.0 \\
27.0 \\
--- \\
--- \\
---\end{array}$ & $\begin{array}{l}29.5 \\
29.0 \\
--- \\
--- \\
---\end{array}$ & $\begin{array}{l}--- \\
--- \\
--- \\
--- \\
---\end{array}$ & $\begin{array}{l}-\cdots \\
-\cdots \\
-\cdots \\
-\cdots \\
\cdots-\end{array}$ & $\begin{array}{l}--- \\
--- \\
--- \\
--- \\
---\end{array}$ & $\begin{array}{l}--- \\
--- \\
--- \\
--- \\
---\end{array}$ & $\begin{array}{l}--- \\
--- \\
--- \\
--- \\
---\end{array}$ & $\begin{array}{l}--- \\
--- \\
--- \\
--- \\
---\end{array}$ \\
\hline $\begin{array}{l}26 \\
27 \\
28 \\
29 \\
30 \\
31\end{array}$ & $\begin{array}{l}--- \\
31.5 \\
31.5 \\
32.0 \\
31.5 \\
---\end{array}$ & $\begin{array}{l}-- \\
27.0 \\
28.0 \\
27.0 \\
26.0 \\
--\end{array}$ & $\begin{array}{l}--- \\
29.0 \\
29.5 \\
29.0 \\
29.0 \\
---\end{array}$ & $\begin{array}{c}34.5 \\
34.5 \\
34.5 \\
--- \\
-- \\
31.5\end{array}$ & $\begin{array}{r}28.0 \\
28.5 \\
28.5 \\
-- \\
-- \\
25.0\end{array}$ & $\begin{array}{c}31.0 \\
31.5 \\
31.5 \\
-- \\
-- \\
29.0\end{array}$ & $\begin{array}{l}--- \\
--- \\
--- \\
30.5 \\
31.0 \\
31.5\end{array}$ & $\begin{array}{l}--- \\
--- \\
\cdots- \\
26.0 \\
26.5 \\
25.0\end{array}$ & $\begin{array}{l}--- \\
-\cdots \\
-- \\
28.0 \\
28.5 \\
28.5\end{array}$ & $\begin{array}{l}23.5 \\
24.5 \\
24.5 \\
25.0 \\
26.0 \\
--\end{array}$ & $\begin{array}{l}18.0 \\
19.5 \\
20.5 \\
20.0 \\
21.0 \\
---\end{array}$ & $\begin{array}{l}20.5 \\
22.0 \\
22.5 \\
22.0 \\
23.5 \\
---\end{array}$ \\
\hline & --- & $-\cdots$ & $\cdots$ & $\ldots$ & -- & -- & -- & $\ldots$ & --- & --- & -- & --- \\
\hline
\end{tabular}


07330700 CADDO CREEK SITE 7, COMPARATIVE SAMPLE SITE NEAR GENE AUTRY, OK--Continued

OXYGEN DISSOLVED (MG/L), WATER YEAR OCTOBER 1996 TO SEPTEMBER 1997

\begin{tabular}{|c|c|c|c|c|c|c|c|c|c|c|c|c|}
\hline \multirow[t]{2}{*}{ DAY } & MAX & MIN & MEAN & MAX & MIN & MEAN & MAX & MIN & MEAN & MAX & MIN & MEAN \\
\hline & \multicolumn{3}{|c|}{ OCTOBER } & \multicolumn{3}{|c|}{ NOVEMBER } & \multicolumn{3}{|c|}{ DECEMBER } & \multicolumn{3}{|c|}{ JANUARY } \\
\hline $\begin{array}{l}1 \\
2 \\
3 \\
4 \\
5\end{array}$ & $\begin{array}{l}--- \\
--- \\
--- \\
--- \\
---\end{array}$ & $\begin{array}{l}--- \\
--- \\
--- \\
--- \\
---\end{array}$ & $\begin{array}{l}--- \\
-- \\
--- \\
--- \\
---\end{array}$ & $\begin{array}{r}10.4 \\
11.8 \\
11.9 \\
10.4 \\
8.4\end{array}$ & $\begin{array}{r}8.7 \\
10.4 \\
10.3 \\
8.2 \\
6.9\end{array}$ & $\begin{array}{r}10.0 \\
11.2 \\
11.3 \\
9.6 \\
7.9\end{array}$ & $\begin{array}{l}--- \\
--- \\
--- \\
--- \\
11.5\end{array}$ & $\begin{array}{l}--- \\
--- \\
--- \\
--- \\
10.3\end{array}$ & $\begin{array}{l}--- \\
--- \\
--- \\
--- \\
10.7\end{array}$ & $\begin{array}{l}11.8 \\
11.4 \\
10.9 \\
11.2 \\
11.3\end{array}$ & $\begin{array}{l}9.1 \\
8.2 \\
7.6 \\
7.9 \\
7.6\end{array}$ & $\begin{array}{r}10.1 \\
9.4 \\
9.3 \\
9.0 \\
10.0\end{array}$ \\
\hline $\begin{array}{r}6 \\
7 \\
8 \\
9 \\
10\end{array}$ & $\begin{array}{r}--- \\
--- \\
-- \\
8.5 \\
8.1\end{array}$ & $\begin{array}{l}--- \\
--- \\
-- \\
7.2 \\
6.9\end{array}$ & $\begin{array}{r}--- \\
--- \\
--- \\
7.6 \\
7.5\end{array}$ & $\begin{array}{r}7.5 \\
13.8 \\
14.5 \\
14.0 \\
10.7\end{array}$ & $\begin{array}{r}6.5 \\
6.7 \\
13.2 \\
10.7 \\
9.2\end{array}$ & $\begin{array}{r}6.9 \\
11.2 \\
14.1 \\
12.4 \\
10.0\end{array}$ & $\begin{array}{r}10.3 \\
9.6 \\
9.9 \\
9.9 \\
10.7\end{array}$ & $\begin{array}{l}8.9 \\
9.2 \\
9.2 \\
9.1 \\
8.5\end{array}$ & $\begin{array}{l}9.4 \\
9.4 \\
9.6 \\
9.4 \\
9.0\end{array}$ & $\begin{array}{l}--- \\
--- \\
-- \\
--- \\
---\end{array}$ & $\begin{array}{l}--- \\
--- \\
--- \\
--- \\
---\end{array}$ & $\begin{array}{l}--- \\
--- \\
--- \\
--- \\
---\end{array}$ \\
\hline $\begin{array}{l}11 \\
12 \\
13 \\
14 \\
15\end{array}$ & $\begin{array}{r}8.6 \\
10.3 \\
7.9 \\
8.0 \\
7.8\end{array}$ & $\begin{array}{l}6.7 \\
6.0 \\
5.7 \\
5.3 \\
5.1\end{array}$ & $\begin{array}{l}7.4 \\
7.3 \\
7.1 \\
6.4 \\
6.1\end{array}$ & $\begin{array}{r}9.3 \\
8.9 \\
10.4 \\
10.3 \\
10.3\end{array}$ & $\begin{array}{l}8.6 \\
8.5 \\
8.6 \\
9.7 \\
9.6\end{array}$ & $\begin{array}{r}9.1 \\
8.7 \\
9.8 \\
10.0 \\
9.9\end{array}$ & $\begin{array}{l}--- \\
--- \\
--- \\
---\end{array}$ & $\begin{array}{l}--- \\
--- \\
-\cdots \\
---\end{array}$ & $\begin{array}{l}--- \\
--- \\
--- \\
--- \\
---\end{array}$ & $\begin{array}{l}--- \\
--- \\
--- \\
--- \\
---\end{array}$ & $\begin{array}{l}--- \\
--- \\
--- \\
--- \\
---\end{array}$ & $\begin{array}{l}--- \\
--- \\
--- \\
--- \\
---\end{array}$ \\
\hline $\begin{array}{l}16 \\
17 \\
18 \\
19 \\
20\end{array}$ & $\begin{array}{l}8.2 \\
7.8 \\
8.3 \\
9.0 \\
9.5\end{array}$ & $\begin{array}{l}4.2 \\
4.2 \\
4.9 \\
5.1 \\
4.9\end{array}$ & $\begin{array}{l}5.8 \\
5.3 \\
6.2 \\
6.7 \\
6.4\end{array}$ & $\begin{array}{r}-- \\
12.8 \\
10.8 \\
9.2\end{array}$ & $\begin{array}{r}-- \\
-- \\
10.8 \\
9.2 \\
8.3\end{array}$ & $\begin{array}{r}--- \\
--- \\
12.1 \\
10.0 \\
8.7\end{array}$ & $\begin{array}{l}12.3 \\
14.0 \\
14.6 \\
14.2\end{array}$ & $\begin{array}{l}-- \\
10.6 \\
12.1 \\
13.3 \\
13.4\end{array}$ & $\begin{array}{l}-- \\
11.5 \\
13.1 \\
14.0 \\
13.8\end{array}$ & $\begin{array}{l}--- \\
--- \\
--- \\
--- \\
---\end{array}$ & $\begin{array}{l}--- \\
--- \\
--- \\
--- \\
---\end{array}$ & $\begin{array}{l}--- \\
--- \\
--- \\
--- \\
---\end{array}$ \\
\hline $\begin{array}{l}21 \\
22 \\
23 \\
24 \\
25\end{array}$ & $\begin{array}{r}-.- \\
-- \\
10.4 \\
9.9\end{array}$ & $\begin{array}{l}--- \\
--- \\
--- \\
9.0 \\
8.7\end{array}$ & $\begin{array}{r}--- \\
--- \\
-- \\
9.8 \\
9.5\end{array}$ & $\begin{array}{r}8.8 \\
9.4 \\
8.7 \\
-- \\
---\end{array}$ & $\begin{array}{r}8.3 \\
8.7 \\
8.1 \\
--- \\
---\end{array}$ & $\begin{array}{r}8.5 \\
9.0 \\
8.4 \\
--- \\
---\end{array}$ & $\begin{array}{l}13.6 \\
12.4 \\
11.1 \\
13.0 \\
13.8\end{array}$ & $\begin{array}{l}11.7 \\
10.5 \\
10.0 \\
10.1 \\
11.9\end{array}$ & $\begin{array}{l}13.0 \\
11.5 \\
10.4 \\
11.8 \\
12.9\end{array}$ & $\begin{array}{l}--- \\
--- \\
--- \\
-- \\
9.9\end{array}$ & $\begin{array}{c}--- \\
--- \\
--- \\
--- \\
6.7\end{array}$ & $\begin{array}{l}--- \\
--- \\
--- \\
--\overline{8.6}\end{array}$ \\
\hline $\begin{array}{l}26 \\
27 \\
28 \\
29 \\
30 \\
31\end{array}$ & $\begin{array}{l}8.9 \\
7.5 \\
8.6 \\
8.3 \\
9.6 \\
9.1\end{array}$ & $\begin{array}{l}7.5 \\
7.0 \\
7.5 \\
7.4 \\
7.5 \\
7.8\end{array}$ & $\begin{array}{l}8.4 \\
7.3 \\
8.1 \\
7.9 \\
8.7 \\
8.7\end{array}$ & $\begin{array}{l}--- \\
--- \\
--- \\
--- \\
--- \\
---\end{array}$ & $\begin{array}{l}--- \\
--- \\
--- \\
--- \\
--- \\
---\end{array}$ & $\begin{array}{l}--- \\
--- \\
--- \\
--- \\
--- \\
---\end{array}$ & $\begin{array}{l}12.9 \\
13.0 \\
13.1 \\
13.3 \\
13.4 \\
11.6\end{array}$ & $\begin{array}{r}11.5 \\
11.2 \\
10.6 \\
10.6 \\
10.1 \\
9.6\end{array}$ & $\begin{array}{l}12.1 \\
12.0 \\
11.6 \\
11.5 \\
11.4 \\
10.3\end{array}$ & $\begin{array}{c}9.0 \\
9.2 \\
-- \\
--- \\
--- \\
---\end{array}$ & $\begin{array}{l}6.2 \\
5.9 \\
--- \\
--- \\
--- \\
---\end{array}$ & $\begin{array}{l}7.1 \\
7.5 \\
--- \\
--- \\
--- \\
---\end{array}$ \\
\hline
\end{tabular}

MONTH 
07330700 CADDO CREEK SITE 7, COMPARATIVE SAMPLE SITE NEAR GENE AUTRY, OK--Continued

OXYGEN DISSOLVED (MG/L), WATER YEAR OCTOBER 1996 TO SEPTEMBER 1997

\begin{tabular}{|c|c|c|c|c|c|c|c|c|c|c|c|c|}
\hline \multirow[t]{2}{*}{ DAY } & MAX & MIN & MEAN & MAX & MIN & MEAN & MAX & MIN & MEAN & MAX & IN & MEAN \\
\hline & \multicolumn{3}{|c|}{ FEBRUARY } & \multicolumn{3}{|c|}{ MARCH } & \multicolumn{3}{|c|}{ APRIL } & \multicolumn{3}{|c|}{ MAY } \\
\hline $\begin{array}{l}1 \\
2 \\
3 \\
4 \\
5\end{array}$ & $\begin{array}{l}--- \\
--- \\
--- \\
--- \\
--\end{array}$ & $\begin{array}{l}--- \\
--- \\
--- \\
--- \\
---\end{array}$ & $\begin{array}{l}--- \\
--- \\
--- \\
--- \\
---\end{array}$ & $\begin{array}{l}--- \\
--- \\
--- \\
--- \\
---\end{array}$ & $\begin{array}{l}--- \\
--- \\
--- \\
--- \\
---\end{array}$ & $\begin{array}{l}--- \\
--- \\
--- \\
--- \\
---\end{array}$ & $\begin{array}{l}--- \\
--- \\
--- \\
-- \\
8.0\end{array}$ & $\begin{array}{l}--- \\
--- \\
--- \\
-- \\
5.0\end{array}$ & $\begin{array}{l}--- \\
--- \\
--- \\
--\overline{5.7}\end{array}$ & $\begin{array}{l}9.0 \\
8.4 \\
8.9 \\
9.2 \\
9.1\end{array}$ & $\begin{array}{l}8.2 \\
7.7 \\
7.8 \\
7.9 \\
7.6\end{array}$ & $\begin{array}{l}8.6 \\
8.1 \\
8.4 \\
8.4 \\
8.3\end{array}$ \\
\hline $\begin{array}{r}6 \\
7 \\
8 \\
9 \\
10\end{array}$ & $\begin{array}{l}--- \\
--- \\
--- \\
--- \\
--\end{array}$ & $\begin{array}{l}--- \\
--- \\
--- \\
--- \\
---\end{array}$ & $\begin{array}{l}--- \\
--- \\
--- \\
--- \\
---\end{array}$ & $\begin{array}{l}--- \\
--- \\
--- \\
--- \\
---\end{array}$ & $\begin{array}{l}--- \\
--- \\
--- \\
--- \\
---\end{array}$ & $\begin{array}{l}--- \\
--- \\
--- \\
--- \\
---\end{array}$ & $\begin{array}{l}5.9 \\
6.6 \\
6.2 \\
7.4 \\
7.2\end{array}$ & $\begin{array}{l}5.0 \\
5.5 \\
5.4 \\
5.8 \\
5.5\end{array}$ & $\begin{array}{l}5.5 \\
6.0 \\
5.8 \\
6.6 \\
6.5\end{array}$ & $\begin{array}{l}8.0 \\
8.6 \\
7.4 \\
6.5 \\
7.1\end{array}$ & $\begin{array}{l}5.8 \\
5.8 \\
5.7 \\
5.2 \\
5.9\end{array}$ & $\begin{array}{l}7.2 \\
6.6 \\
6.4 \\
5.9 \\
6.7\end{array}$ \\
\hline $\begin{array}{l}11 \\
12 \\
13 \\
14 \\
15\end{array}$ & $\begin{array}{l}--- \\
--- \\
--- \\
--- \\
---\end{array}$ & $\begin{array}{l}--- \\
--- \\
--- \\
--- \\
---\end{array}$ & $\begin{array}{l}--- \\
--- \\
--- \\
--- \\
---\end{array}$ & $\begin{array}{l}--- \\
--- \\
--- \\
--- \\
---\end{array}$ & $\begin{array}{l}--- \\
--- \\
--- \\
--- \\
---\end{array}$ & $\begin{array}{l}--- \\
--- \\
--- \\
--- \\
---\end{array}$ & $\begin{array}{l}--- \\
--- \\
--- \\
--- \\
---\end{array}$ & $\begin{array}{l}--- \\
--- \\
--- \\
--- \\
---\end{array}$ & $\begin{array}{l}--- \\
--- \\
--- \\
--- \\
---\end{array}$ & $\begin{array}{l}7.4 \\
7.8 \\
8.4 \\
8.0 \\
8.7\end{array}$ & $\begin{array}{l}6.6 \\
6.6 \\
7.0 \\
6.9 \\
6.8\end{array}$ & $\begin{array}{l}7.0 \\
7.2 \\
7.8 \\
7.3 \\
7.6\end{array}$ \\
\hline $\begin{array}{l}16 \\
17 \\
18 \\
19 \\
20\end{array}$ & $\begin{array}{l}--- \\
--- \\
--- \\
--- \\
--\end{array}$ & $\begin{array}{l}--- \\
--- \\
--- \\
--- \\
---\end{array}$ & $\begin{array}{l}--- \\
--- \\
--- \\
--- \\
---\end{array}$ & $\begin{array}{l}--- \\
--- \\
--- \\
--- \\
---\end{array}$ & $\begin{array}{l}--- \\
--- \\
--- \\
--- \\
---\end{array}$ & $\begin{array}{l}--- \\
--- \\
--- \\
--- \\
---\end{array}$ & $\begin{array}{l}--- \\
--- \\
--- \\
--- \\
---\end{array}$ & $\begin{array}{l}--- \\
--- \\
--- \\
--- \\
---\end{array}$ & $\begin{array}{l}--- \\
--- \\
--- \\
--- \\
---\end{array}$ & $\begin{array}{l}8.6 \\
8.3 \\
8.3 \\
7.0 \\
7.5\end{array}$ & $\begin{array}{l}6.3 \\
6.0 \\
5.9 \\
5.8 \\
6.2\end{array}$ & $\begin{array}{l}7.4 \\
7.0 \\
6.8 \\
6.1 \\
7.0\end{array}$ \\
\hline $\begin{array}{l}21 \\
22 \\
23 \\
24 \\
25\end{array}$ & $\begin{array}{l}--- \\
--- \\
-- \\
--- \\
--\end{array}$ & $\begin{array}{l}--- \\
--- \\
--- \\
--- \\
---\end{array}$ & $\begin{array}{l}--- \\
--- \\
--- \\
--- \\
---\end{array}$ & $\begin{array}{l}--- \\
--- \\
--- \\
--- \\
---\end{array}$ & $\begin{array}{l}--- \\
--- \\
--- \\
---\end{array}$ & $\begin{array}{l}--- \\
--- \\
--- \\
--- \\
---\end{array}$ & $\begin{array}{r}--- \\
--- \\
8.9 \\
9.1 \\
9.3\end{array}$ & $\begin{array}{r}--- \\
-- \\
7.7 \\
8.1 \\
8.9\end{array}$ & $\begin{array}{r}--- \\
-- \\
8.3 \\
8.5 \\
9.1\end{array}$ & $\begin{array}{l}7.9 \\
7.8 \\
7.7 \\
7.7 \\
7.5\end{array}$ & $\begin{array}{l}7.5 \\
7.3 \\
7.2 \\
6.8 \\
6.5\end{array}$ & $\begin{array}{l}7.7 \\
7.7 \\
7.5 \\
7.3 \\
6.9\end{array}$ \\
\hline $\begin{array}{l}26 \\
27 \\
28 \\
29 \\
30 \\
31\end{array}$ & $\begin{array}{l}--- \\
-- \\
--- \\
--- \\
---\end{array}$ & $\begin{array}{l}--- \\
--- \\
--- \\
--- \\
--- \\
---\end{array}$ & $\begin{array}{l}--- \\
--- \\
--- \\
--- \\
--- \\
---\end{array}$ & $\begin{array}{l}--- \\
-- \\
--- \\
--- \\
---\end{array}$ & $\begin{array}{l}\dot{-}- \\
--- \\
--- \\
-- \\
-\ldots \\
--\end{array}$ & $\begin{array}{l}--- \\
--- \\
--- \\
--- \\
--- \\
---\end{array}$ & $\begin{array}{r}9.4 \\
9.6 \\
9.4 \\
9.2 \\
9.2 \\
---\end{array}$ & $\begin{array}{r}8.7 \\
9.2 \\
8.7 \\
8.6 \\
8.3 \\
---\end{array}$ & $\begin{array}{r}9.1 \\
9.4 \\
9.1 \\
8.8 \\
8.5 \\
--\end{array}$ & $\begin{array}{l}7.3 \\
6.7 \\
8.0 \\
8.4 \\
7.1 \\
7.5\end{array}$ & $\begin{array}{l}6.1 \\
6.1 \\
6.5 \\
7.0 \\
4.4 \\
4.8\end{array}$ & $\begin{array}{l}6.7 \\
6.4 \\
7.2 \\
7.5 \\
6.3 \\
5.9\end{array}$ \\
\hline $\mathrm{TH}$ & -- & --- & --- & --- & --- & --- & --- & --- & --- & 9.2 & 4.4 & 7.2 \\
\hline
\end{tabular}


07330700 CADDO CREEK SITE 7, COMPARATIVE SAMPLE SITE NEAR GENE AUTRY, OK--Continued OXYGEN DISSOLVED (MG/L), WATER YEAR OCTOBER 1996 TO SEPTEMBER 1997

\begin{tabular}{|c|c|c|c|c|c|c|c|c|c|c|c|c|}
\hline \multirow[t]{2}{*}{ DAY } & MAX & MIN & MEAN & MAX & MIN & MEAN & MAX & MIN & MEAN & MAX & MIN & MEAN \\
\hline & \multicolumn{3}{|c|}{ JUNE } & \multicolumn{3}{|c|}{ JULY } & \multicolumn{3}{|c|}{ AUGUST } & \multicolumn{3}{|c|}{ SEPTEMBER } \\
\hline $\begin{array}{l}1 \\
2 \\
3 \\
4 \\
5\end{array}$ & $\begin{array}{l}6.9 \\
6.8 \\
7.1 \\
7.3 \\
7.5\end{array}$ & $\begin{array}{l}5.9 \\
6.4 \\
6.5 \\
6.7 \\
6.5\end{array}$ & $\begin{array}{l}6.6 \\
6.6 \\
6.8 \\
7.0 \\
7.0\end{array}$ & $\begin{array}{l}8.1 \\
8.3 \\
8.6 \\
8.9 \\
9.5\end{array}$ & $\begin{array}{l}5.2 \\
4.9 \\
4.8 \\
4.9 \\
5.3\end{array}$ & $\begin{array}{l}6.3 \\
6.2 \\
6.2 \\
6.4 \\
7.0\end{array}$ & $\begin{array}{r}9.0 \\
9.6 \\
10.4 \\
9.5 \\
9.4\end{array}$ & $\begin{array}{l}4.7 \\
4.3 \\
4.0 \\
4.0 \\
4.0\end{array}$ & $\begin{array}{l}6.4 \\
6.2 \\
6.3 \\
6.0 \\
6.0\end{array}$ & $\begin{array}{r}10.7 \\
10.0 \\
8.2 \\
7.6 \\
8.6\end{array}$ & $\begin{array}{l}3.9 \\
3.8 \\
3.4 \\
3.7 \\
4.5\end{array}$ & $\begin{array}{l}6.4 \\
6.0 \\
4.9 \\
4.9 \\
5.9\end{array}$ \\
\hline $\begin{array}{r}6 \\
7 \\
8 \\
9 \\
10\end{array}$ & $\begin{array}{c}8.6 \\
--- \\
--- \\
--- \\
---\end{array}$ & $\begin{array}{c}6.5 \\
--- \\
--- \\
--- \\
--\end{array}$ & $\begin{array}{l}7.6 \\
\cdots- \\
-- \\
---\end{array}$ & $\begin{array}{r}9.8 \\
9.6 \\
10.4 \\
9.7 \\
10.7\end{array}$ & $\begin{array}{l}5.6 \\
5.7 \\
4.3 \\
3.9 \\
4.0\end{array}$ & $\begin{array}{l}7.0 \\
7.0 \\
7.0 \\
5.9 \\
6.8\end{array}$ & $\begin{array}{r}8.2 \\
7.3 \\
9.3 \\
10.9 \\
11.2\end{array}$ & $\begin{array}{l}2.5 \\
3.9 \\
5.8 \\
5.9 \\
5.5\end{array}$ & $\begin{array}{l}5.4 \\
5.8 \\
7.1 \\
8.0 \\
7.7\end{array}$ & $\begin{array}{l}8.6 \\
8.9 \\
8.8 \\
8.8 \\
9.0\end{array}$ & $\begin{array}{l}4.2 \\
4.2 \\
3.7 \\
3.6 \\
4.0\end{array}$ & $\begin{array}{l}5.7 \\
5.8 \\
5.3 \\
5.3 \\
5.8\end{array}$ \\
\hline $\begin{array}{l}11 \\
12 \\
13 \\
14 \\
15\end{array}$ & $\begin{array}{l}--- \\
--- \\
--- \\
--- \\
---\end{array}$ & $\begin{array}{l}-- \\
--- \\
-- \\
---\end{array}$ & $\begin{array}{l}--- \\
--- \\
--- \\
--- \\
---\end{array}$ & $\begin{array}{r}10.2 \\
10.3 \\
10.2 \\
9.6 \\
10.1\end{array}$ & $\begin{array}{l}3.9 \\
3.5 \\
3.1 \\
3.0 \\
4.4\end{array}$ & $\begin{array}{l}6.5 \\
6.1 \\
6.2 \\
5.7 \\
6.3\end{array}$ & $\begin{array}{l}11.2 \\
--- \\
--- \\
--- \\
---\end{array}$ & $\begin{array}{c}4.4 \\
--- \\
--- \\
--- \\
---\end{array}$ & $\begin{array}{c}6.8 \\
--- \\
--- \\
--- \\
---\end{array}$ & $\begin{array}{r}9.3 \\
9.7 \\
8.4 \\
8.1 \\
---\end{array}$ & $\begin{array}{r}4.5 \\
4.6 \\
3.7 \\
3.0 \\
--\end{array}$ & $\begin{array}{r}6.1 \\
6.4 \\
5.5 \\
4.8 \\
--\end{array}$ \\
\hline $\begin{array}{l}16 \\
17 \\
18 \\
19 \\
20\end{array}$ & $\begin{array}{l}--- \\
--- \\
-7.1 \\
7.3\end{array}$ & $\begin{array}{r}--- \\
--- \\
-- \\
6.0 \\
4.9\end{array}$ & $\begin{array}{l}--- \\
--- \\
-- \\
6.6 \\
6.3\end{array}$ & \begin{tabular}{l}
10.5 \\
-- \\
\hdashline- \\
10.2 \\
10.5
\end{tabular} & $\begin{array}{c}5.0 \\
--- \\
-- \\
4.5 \\
4.0\end{array}$ & $\begin{array}{c}7.0 \\
-- \\
-- \\
7.0 \\
6.4\end{array}$ & $\begin{array}{l}--- \\
--- \\
--- \\
--- \\
---\end{array}$ & $\begin{array}{l}--- \\
--- \\
--- \\
--- \\
---\end{array}$ & $\begin{array}{l}--- \\
--- \\
--- \\
--- \\
---\end{array}$ & $\begin{array}{l}--- \\
--- \\
--- \\
--- \\
---\end{array}$ & $\begin{array}{l}--- \\
--- \\
--- \\
--- \\
---\end{array}$ & $\begin{array}{l}--- \\
--- \\
--- \\
--- \\
---\end{array}$ \\
\hline $\begin{array}{l}21 \\
22 \\
23 \\
24 \\
25\end{array}$ & $\begin{array}{l}7.1 \\
7.5 \\
8.3 \\
6.9 \\
6.9\end{array}$ & $\begin{array}{l}4.8 \\
5.0 \\
6.0 \\
6.1 \\
3.3\end{array}$ & $\begin{array}{l}6.2 \\
6.3 \\
6.6 \\
6.5 \\
5.6\end{array}$ & $\begin{array}{l}10.6 \\
10.4 \\
--- \\
--- \\
---\end{array}$ & $\begin{array}{c}3.5 \\
3.4 \\
--- \\
---\end{array}$ & $\begin{array}{l}6.1 \\
5.7 \\
--- \\
--- \\
---\end{array}$ & $\begin{array}{l}--- \\
--- \\
--- \\
--- \\
---\end{array}$ & $\begin{array}{l}--- \\
--- \\
--- \\
--- \\
---\end{array}$ & $\begin{array}{l}--- \\
--- \\
--- \\
--- \\
---\end{array}$ & $\begin{array}{l}--- \\
--- \\
--- \\
--- \\
---\end{array}$ & $\begin{array}{l}--- \\
--- \\
--- \\
--- \\
---\end{array}$ & $\begin{array}{l}--- \\
--- \\
--- \\
--- \\
---\end{array}$ \\
\hline $\begin{array}{l}26 \\
27 \\
28 \\
29 \\
30 \\
31\end{array}$ & $\begin{array}{r}7.4 \\
7.3 \\
7.0 \\
8.1 \\
8.0 \\
---\end{array}$ & $\begin{array}{r}2.2 \\
5.6 \\
5.5 \\
5.5 \\
5.4 \\
-\end{array}$ & $\begin{array}{r}4.8 \\
6.2 \\
6.1 \\
6.3 \\
6.3 \\
---\end{array}$ & $\begin{array}{l}11.1 \\
--- \\
--- \\
-\cdots \\
-- \\
12.4\end{array}$ & $\begin{array}{c}4.1 \\
--- \\
--- \\
-- \\
-- \\
4.4\end{array}$ & $\begin{array}{l}6.5 \\
--- \\
--- \\
-- \\
-- \\
7.7\end{array}$ & $\begin{array}{r}-- \\
10.1 \\
10.0 \\
9.7 \\
9.7 \\
10.4\end{array}$ & $\begin{array}{l}3.9 \\
3.4 \\
4.4 \\
3.9 \\
3.7\end{array}$ & $\begin{array}{r}5.9 \\
6.0 \\
6.4 \\
5.9 \\
6.1\end{array}$ & $\begin{array}{r}7.2 \\
6.9 \\
7.1 \\
8.7 \\
8.4 \\
--\end{array}$ & $\begin{array}{r}5.1 \\
4.4 \\
4.1 \\
4.2 \\
4.3 \\
---\end{array}$ & $\begin{array}{r}6.0 \\
5.3 \\
5.0 \\
5.8 \\
5.6 \\
--\end{array}$ \\
\hline
\end{tabular}

MONTH 
LOCATION.--Lat $34^{\circ} 13^{\prime} 58^{\prime \prime}$, long $97^{\circ} 02^{\prime} 16^{\prime \prime}$, in SW 1/4 SW 1/4 sec.6, T.4 S., R.3 E., Carter County, Hydrologic Unit 11130303, on right bank $3.1 \mathrm{mi}$ north of U.S.Highway 70, $3.8 \mathrm{mi}$ south of Gene Autry, and at mile 7.1.

PERIOD OF RECORD.--October 1996 to August 1997 (discontinued).

REMARKS.--Water temperature, specific conductance, $\mathrm{pH}$, alkalinity, and dissolved oxygen were determined in the field.

\section{WATER-QUALITY DATA}

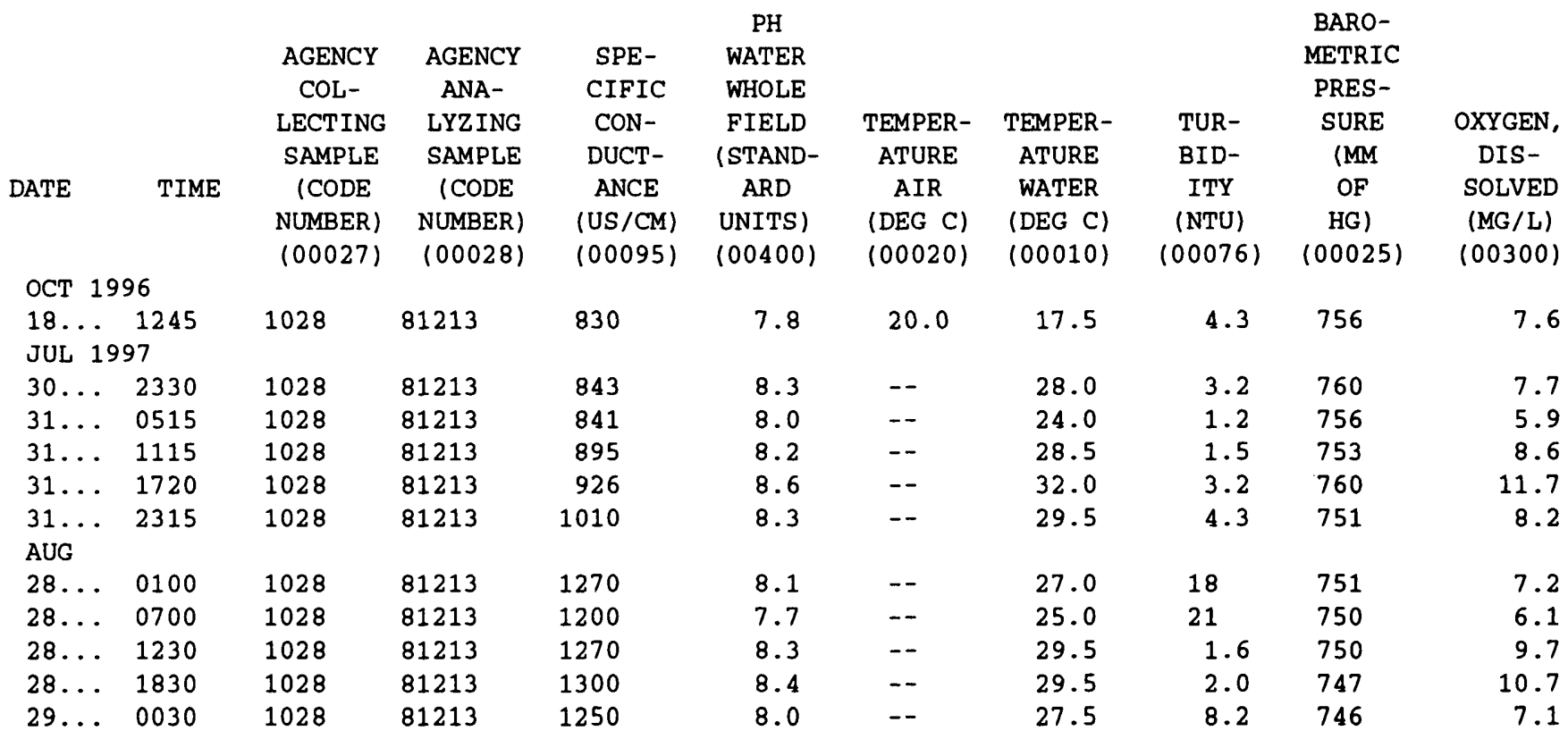

\begin{tabular}{|c|c|c|c|c|c|c|c|c|c|c|}
\hline DATE & $\begin{array}{c}\text { OXYGEN, } \\
\text { DIS- } \\
\text { SOLVED } \\
\text { (PER- } \\
\text { CENT } \\
\text { SATUR- } \\
\text { ATION) } \\
\text { (00301) }\end{array}$ & $\begin{array}{c}\text { OXYGEN } \\
\text { DEMAND, } \\
\text { BIOCHEM } \\
\text { CARBON. } \\
20 \\
(\text { MG/L) } \\
(80087)\end{array}$ & $\begin{array}{c}\text { OXYGEN } \\
\text { DEMAND, } \\
\text { BIOCHEM } \\
\text { CARBON. } \\
\text { 20-FILT. } \\
\text { (MG/L) }\end{array}$ & $\begin{array}{l}\text { ALKA- } \\
\text { LINITY } \\
\text { WAT DIS } \\
\text { TOT IT } \\
\text { FIELD } \\
\text { MG/L AS } \\
\text { CACO3 } \\
(39086)\end{array}$ & $\begin{array}{c}\text { SULFIDE } \\
\text { TOTAL } \\
\text { (MG /L } \\
\text { AS S) } \\
(00745)\end{array}$ & $\begin{array}{c}\text { SULFATE } \\
\text { DIS- } \\
\text { SOLVED } \\
\text { (MG/L } \\
\text { AS SO4) } \\
(00945)\end{array}$ & $\begin{array}{l}\text { NITRO- } \\
\text { GEN, } \\
\text { NITRATE } \\
\text { TOTAL } \\
\text { (MG/L } \\
\text { AS N) } \\
(00620)\end{array}$ & $\begin{array}{c}\text { NITRO- } \\
\text { GEN, } \\
\text { NITRITE } \\
\text { TOTAL } \\
\text { (MG/L } \\
\text { AS N) } \\
(00615)\end{array}$ & $\begin{array}{c}\text { NITRO- } \\
\text { GEN, } \\
\text { NO2+NO3 } \\
\text { TOTAL } \\
\text { (MG/L } \\
\text { AS N) } \\
(00630)\end{array}$ & $\begin{array}{l}\text { NITRO- } \\
\text { GEN, } \\
\text { AMMONIA } \\
\text { TOTAL } \\
\text { (MG/L } \\
\text { AS N) } \\
(00610)\end{array}$ \\
\hline \multicolumn{11}{|c|}{ OCT 1996} \\
\hline $\begin{array}{l}18 . . \\
\text { JUL }\end{array}$ & $97^{80}$ & -- & -- & 202 & $<1.0$ & 39 & 2.04 & .260 & 2.30 & 2.00 \\
\hline $30 .$. & 99 & 2.9 & 2.8 & 160 & -- & -- & 3.82 & .076 & 3.90 & .080 \\
\hline $31 .$. & 71 & 3.1 & 1.6 & 159 & -- & -- & 3.35 & .052 & 3.40 & .140 \\
\hline $31 \ldots$ & 112 & 3.3 & 1.7 & 158 & -- & -- & 2.96 & .044 & 3.00 & .070 \\
\hline $31 .$. & 161 & 4.3 & 2.5 & 163 & -- & -- & 3.07 & .034 & 3.10 & .050 \\
\hline $\begin{array}{l}31 \ldots \\
\text { AUG }\end{array}$ & 110 & 2.7 & 1.8 & 157 & -- & -- & 3.56 & .042 & 3.60 & .070 \\
\hline 28. & 92 & 5. & 4. & 142 & -- & -- & 5.54 & .058 & 5.60 & .060 \\
\hline 28. & 75 & 4.5 & 5.1 & 143 & -- & -- & 4.71 & .087 & 4.80 & .120 \\
\hline 28 & 130 & 4.0 & 3.0 & 141 & -- & -- & 4.61 & .092 & 4.70 & .060 \\
\hline 28 & 144 & 4.1 & 3.4 & 141 & -- & -- & 4.71 & .086 & 4.80 & .030 \\
\hline $29 .$. & 92 & 3.5 & 2.8 & 140 & -- & -- & 5.18 & .120 & 5.30 & .090 \\
\hline
\end{tabular}


WATER-QUALITY DATA

\begin{tabular}{|c|c|c|}
\hline \multirow{4}{*}{ DATE } & $\begin{array}{c}\text { NITRO- } \\
\text { GEN, }\end{array}$ & $\begin{array}{c}\text { NITRO- } \\
\text { GEN, }\end{array}$ \\
\hline & AMMONIA & ORGANIC \\
\hline & TOTAL & $\begin{array}{l}\text { TOTAL } \\
\text { (MG/L }\end{array}$ \\
\hline & $\begin{array}{l}\text { AS NH4) } \\
(71845)\end{array}$ & $\begin{array}{c}\text { AS N) } \\
(00605)\end{array}$ \\
\hline
\end{tabular}

NITRO-

GEN, AM-

MONIA +

ORGANIC

TOTAL

(MG/L

AS N)

(00625)

$$
\begin{aligned}
& 2.6 \\
& .89 \\
& .86 \\
& .77 \\
& .75 \\
& .83 \\
& 1.4 \\
& 1.4 \\
& 1.5 \\
& 1.6 \\
& 1.5
\end{aligned}
$$

$18 \ldots 2.6$

JUL 1997

$30 \ldots \quad .10$

$31 \ldots . \quad .18$

$31 \ldots .09$

$31 \ldots . \quad .06$

$31 \ldots . .09$

AUG

$28 \ldots \quad .08$

$28 \ldots . .15$

$28 \ldots . \quad .08$

$28 \ldots .04$

$29 \ldots . .12$

.60
.81
.72
.70
.70
.76
1.3
1.3
1.4
1.6
1.4

DATE

AUG 01-29

AUG 01-29

AUG 01-29

AGENCY
COL-
LECTING
SAMPLE
(CODE
NUMBER)
$(00027)$
1028
1028
1028

AGENCY

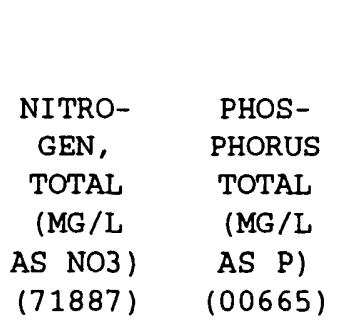

4.9

4.8

4.3

3.8

3.8

4.4

7.0

6.2

6.2

6.4

6.8

$\begin{array}{ll}22 & .570 \\ 21 & .930 \\ 19 & .850 \\ 17 & .840 \\ 17 & .880 \\ 20 & .880 \\ 31 & 1.40 \\ 27 & 1.40 \\ 27 & 1.40 \\ 28 & 1.40 \\ 30 & 1.40\end{array}$

PERI -

PHYTON

BIOMASS

ASH

WEIGHT

G/SQ M

(00572)

1.02

.180

2.02
ECTING

SAMPLE

(CODE)

00027)

1028

AGENCY
ANA-
LYZING
SAMPLE
(CODE
NUMBER)
(00028)
81213
81213
81213

AGENCY

COL-

LECTING

SAMPLE

DATE TIME

(CODE

NUMBER )

(00027)

JUL 1997

$16 \ldots 2338$

$16 \ldots 2348$

$16 \ldots 2357$

$17 \ldots 0004$

$17 \ldots 0014$

$17 \ldots 0025$

$17 \ldots 0038$

$17 \ldots 0048$

$17 \ldots 0100$

$17 \ldots 0111$

$17 \ldots 0124$

$17 \ldots 0136$

$17 \ldots 0152$

$17 \ldots 0237$

$17 \ldots 0337$

$17 \ldots 0437$

$17 \ldots 0536$

$17 \ldots 0606$

$17 \ldots 0705$

$17 \ldots 0800$

1028
1028
1028
1028
1028
1028
1028
1028
1028
1028
1028
1028
1028
1028
1028
1028
1028
1028
1028
1028

1028

1028

1028

1028

1028

1028

1028

1028

1028

1028

1028

1028

1028

1028

1028

\begin{tabular}{|c|c|}
\hline & $\begin{array}{c}\text { CHLOR-A } \\
\text { PHYTO- } \\
\text { PLANK- } \\
\text { TON }\end{array}$ \\
\hline PHENOLS & CHROMO \\
\hline $\begin{array}{l}\text { TOTAL } \\
\text { (UG/L) }\end{array}$ & $\begin{array}{c}\text { FLUOROM } \\
\text { (UG/L) }\end{array}$ \\
\hline$(32730)$ & $(70953)$ \\
\hline$<1$ & 7.20 \\
\hline-- & 5.50 \\
\hline & 5.20 \\
\hline-- & 16.0 \\
\hline-- & 22.0 \\
\hline-- & 4.00 \\
\hline 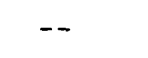 & 8.80 \\
\hline & 8.50 \\
\hline . & 12.0 \\
\hline-- & $\begin{array}{r}15.0 \\
9.50\end{array}$ \\
\hline
\end{tabular}

PHOS-

PHORUS

HYDRO.

+ ORTHO

TOTAL

(MG /L

AS P)

(00678)

PERI -

PHYTON

BIOMASS

TOTAL

DRY

WEIGHT

G/SQ M

(00573)

11.6

1.41

8.91

CHLOR-A

PERI -

PHYTON

CHROMO-

GRAPHIC

FLUOROM

(MG/M2)

(70957)

4060

1690

3460

\section{AGENCY}

ANA-

LYZING

SAMPLE PROPANE

(CODE TOTAL

NUMBER) (UG/L)

(00028)

(82358)

$$
\begin{aligned}
& 81213 \\
& 81213 \\
& 81213 \\
& 81213 \\
& 81213 \\
& 81213 \\
& 81213 \\
& 81213 \\
& 81213 \\
& 81213 \\
& 81213 \\
& 81213 \\
& 81213 \\
& 81213 \\
& 81213 \\
& 81213 \\
& 81213 \\
& 81213 \\
& 81213 \\
& 81213
\end{aligned}
$$


LOCATION.--Lat $34^{\circ} 13^{\prime} 33^{\prime \prime}$, long $97^{\circ} 00^{\prime} 55^{\prime \prime}$, in SE 1/4 SW 1/4 sec.8, T.4 S., R.3 E., Carter County, Hydrologic Unit 11130303, on right downstream bank $3.0 \mathrm{mi}$ south of Gene Autry, $1.5 \mathrm{mi}$ east, $1.4 \mathrm{mi}$ south on private land, and at mile 3.9.

PERIOD OF RECORD.--October 1996 to August 1997 (discontinued).

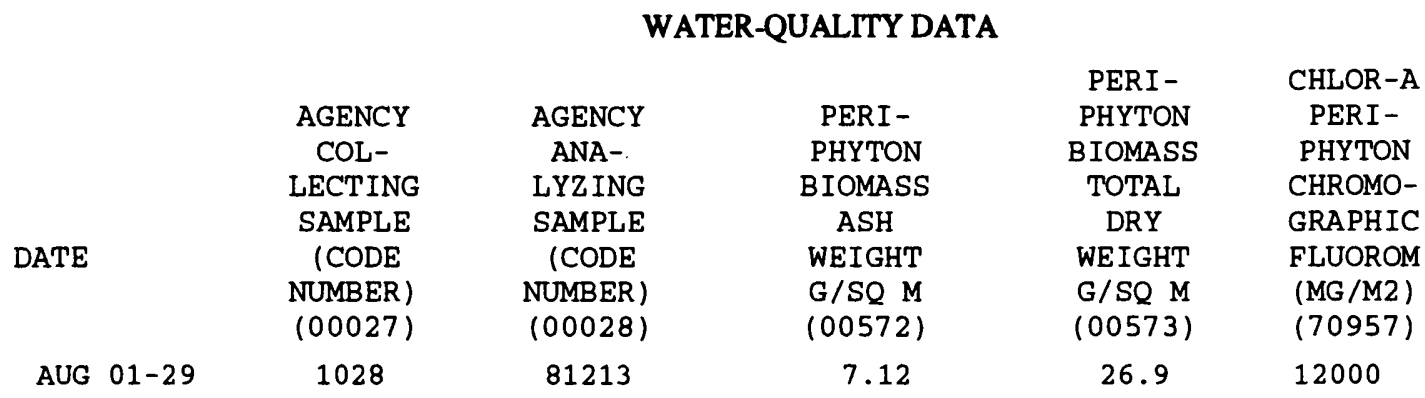

07330800 CADDO CREEK SITE 9, COMPARATIVE SAMPLE SITE NEAR GENE AUTRY, OK

LOCATION.--Lat $34^{\circ} 13^{\prime} 51^{\prime \prime}$, long $97^{\circ} 00^{\prime} 47^{\prime \prime}$, in SE 1/4 SW 1/4 sec.5, T.4 S., R.3 E., Carter County, Hydrologic Unit 11130303, on left downstream bank, $3.0 \mathrm{mi}$ south of Gene Autry, $1.5 \mathrm{mi}$ east, $1 \mathrm{mi}$ south on private land, and at mile 3.3.

DRAINAGE AREA.--349 $\mathrm{mi}^{2}$.

PERIOD OF RECORD.--April to August 1997 (gage heights only) (discontinued).

GAGE.--Water-stage recorder. Datum of gage is $660 \mathrm{ft}$ above sea level from topographic map.

REMARKS.--Records fair.

EXTREMES FOR CURRENT PERIOD.--Maximum gage height, $14.92 \mathrm{ft}$, May 31 ; minimum, $.34 \mathrm{ft}$, at times.

GAGE HEIGHT, FEET, WATER YEAR OCTOBER 1996 TO SEPTEMBER 1997

\begin{tabular}{|c|c|c|c|c|c|c|c|c|c|c|c|c|}
\hline DAY & MAX & $\begin{array}{c}\text { MIN } \\
\text { FEBRUAR }\end{array}$ & MEAN & MAX & $\begin{array}{r}\text { MIN } \\
\text { MARCH }\end{array}$ & MEAN & MAX & $\begin{array}{c}\text { MIN } \\
\text { APRIL }\end{array}$ & MEAN & MAX & $\begin{array}{l}\text { MIN } \\
\text { MAY }\end{array}$ & MEAN \\
\hline 1 & -.. & $\ldots$ & --- & --- & --- & -- & -- &.-- & -- & 3.70 & 3.55 & 3.62 \\
\hline 2 & --- & --- & --- & --- & --- & $\cdots$ & -- & -- & -- & 3.58 & 3.36 & 3.44 \\
\hline 3 & --- & --- & -- & --- & --- & --- & --- & --- & --- & 3.38 & 2.52 & 2.95 \\
\hline 4 & -.. & -- & -- & -.. & -.- & -- & -- & -- & -- & 2.52 & 2.15 & 2.31 \\
\hline 5 & -- & -- & --- & --- & --. & -- & -- & -- & -.- & 2.15 & 2.02 & 2.07 \\
\hline 6 & --- & -- & --- & --- & --- & -.- & -.. & -.. & -- & 2.14 & 2.06 & 2.08 \\
\hline 7 & -- & -- & -- & --- & --- & -- & -.- & -- & -- & 2.18 & 2.11 & 2.15 \\
\hline 8 & --- & -- & --- & --- & --- & -- & -- & $-\cdot$ & -- & 2.21 & 2.12 & 2.17 \\
\hline 9 & --- & -- & --- & -- & -. & -- & -- & -.- & -- & 6.53 & 2.21 & 3.82 \\
\hline 10 & --- & $-\cdot$ & --- & --- & --- & -- & -- & -- & -- & 6.26 & 3.58 & 4.57 \\
\hline 11 & --- & -.. & --- & -- & --- & -.- & 11.49 & 1.59 & 5.74 & 3.58 & 2.81 & 3.11 \\
\hline 12 & --- & --- & -- & -.- & --. & --- & 12.26 & 7.54 & 10.01 & 2.81 & 2.42 & 2.62 \\
\hline 13 & -- & -- & -- & -. & --- & -- & 7.54 & 4.86 & 5.96 & 2.42 & 2.12 & 2.26 \\
\hline 14 & -- & --- & -- & --- & $\cdots$ & -- & 4.86 & 3.98 & 4.35 & 2.12 & 1.92 & 2.01 \\
\hline 15 & --- & --- & --- & --- & -.- & -- & 3.98 & 3.55 & 3.76 & 1.92 & 1.81 & 1.86 \\
\hline 16 & -. & $\cdots$ & -- & -. & --- & -.. & 3.57 & 3.37 & 3.44 & 1.83 & 1.68 & 1.77 \\
\hline 17 & -- & --- & -- & --- & --- & --- & 3.53 & 3.32 & 3.46 & 1.69 & 1.60 & 1.65 \\
\hline 18 & --- & -- & --- & -- & --- & -- & 3.32 & 2.55 & 2.96 & 1.60 & 1.51 & 1.55 \\
\hline 19 & --- & --- & --- & -- & --- & --- & 2.55 & 2.26 & 2.38 & 6.53 & 1.46 & 3.86 \\
\hline 20 & -- & --- & --- & --- & -- & --- & 2.27 & 2.12 & 2.18 & 7.38 & 4.53 & 5.92 \\
\hline 21 & --- & -.. & $\ldots$ & $\ldots$ & -.- &.- & 2.51 & 2.26 & 2.37 & 4.53 & 3.60 & 4.02 \\
\hline 22 & -- & --- & -- & --- & --- & --- & 2.51 & 2.32 & 2.45 & 3.60 & 3.10 & 3.35 \\
\hline 23 & --- & --- & -- & -- & -- & --- & 2.32 & 2.11 & 2.17 & 3.10 & 2.65 & 2.91 \\
\hline 24 & -- & --- & --- & -- & --- & -- & 2.11 & 1.90 & 1.97 & 2.65 & 2.32 & 2.43 \\
\hline 25 & --- & -- &.- & -. & -- &.- & 6.77 & 1.92 & 3.09 & 2.32 & 2.16 & 2.22 \\
\hline 26 & --- & -- & -- & --- & -- & -- & 8.16 & 6.01 & 7.18 & 4.97 & 2.32 & 4.07 \\
\hline 27 & -- & --- & -- & --- & -- & --- & 6.96 & 6.00 & 6.47 & 4.32 & 3.05 & 3.64 \\
\hline 28 & -- & -- & --- & --- & --- & -- & 6.00 & 4.69 & 5.29 & 3.05 & 2.61 & 2.74 \\
\hline 29 & -- & --- & -- & -- & --- & -- & 4.70 & 4.05 & 4.34 & 2.61 & 2.09 & 2.37 \\
\hline 30 & -- & -- & -- & -- & -- & -- & 4.05 & 3.70 & 3.85 & 12.77 & 1.98 & 6.67 \\
\hline 31 & -- & --- & --- & -- & -- & --- & -- & -- & --- & 14.92 & 8.82 & 11.86 \\
\hline TT & --. & --- & -- & -- & -- & -- & -- & --- & -- & 14.92 & 1.46 & 3.29 \\
\hline
\end{tabular}


07330800 CADDO CREEK SITE 9, COMPARATIVE SAMPLE SITE NEAR GENE AUTRY, OK--Continued

\section{GAGE HEIGHT, FEET, WATER YEAR OCTOBER 1996 TO SEPTEMBER 1997}

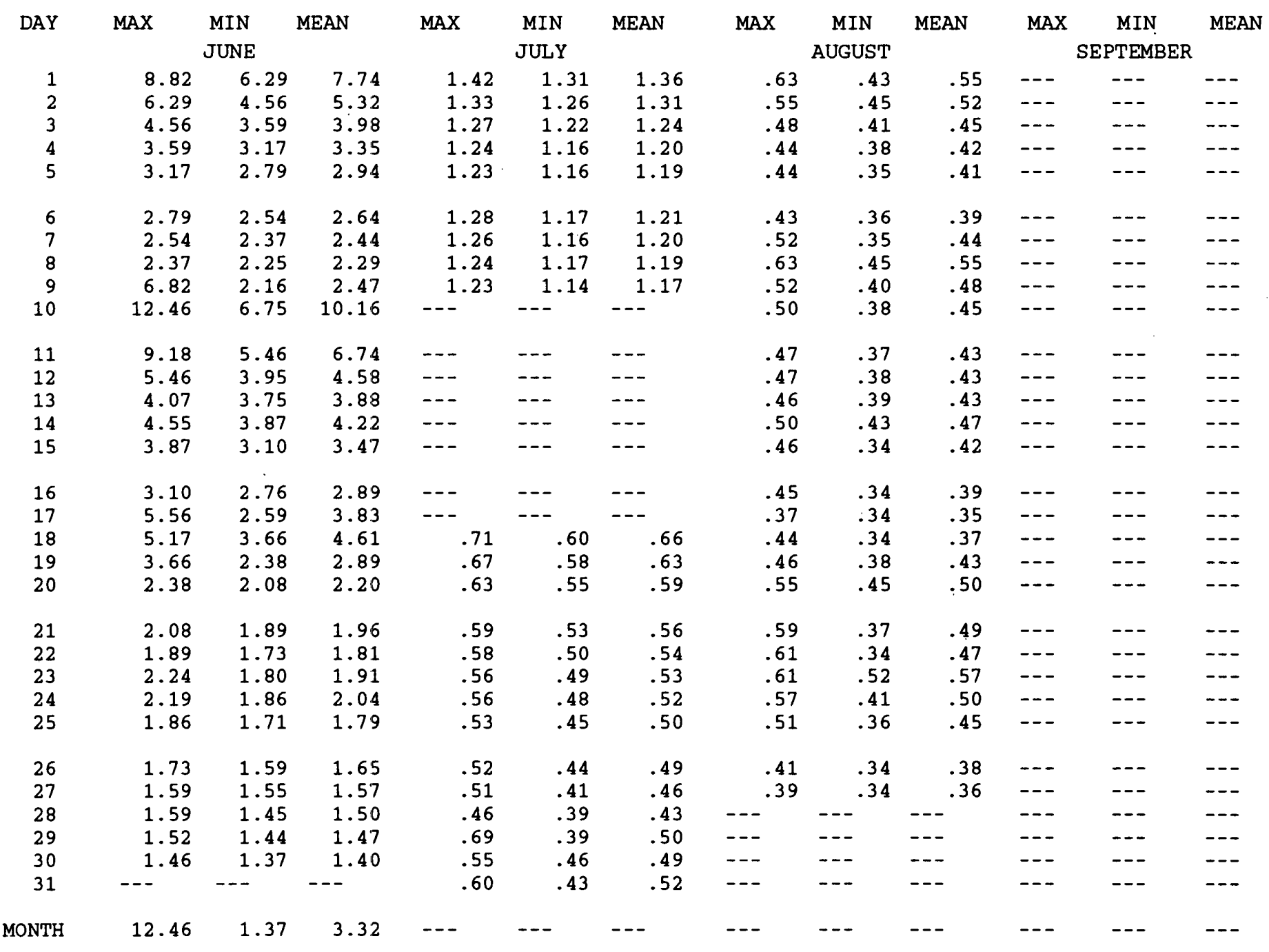




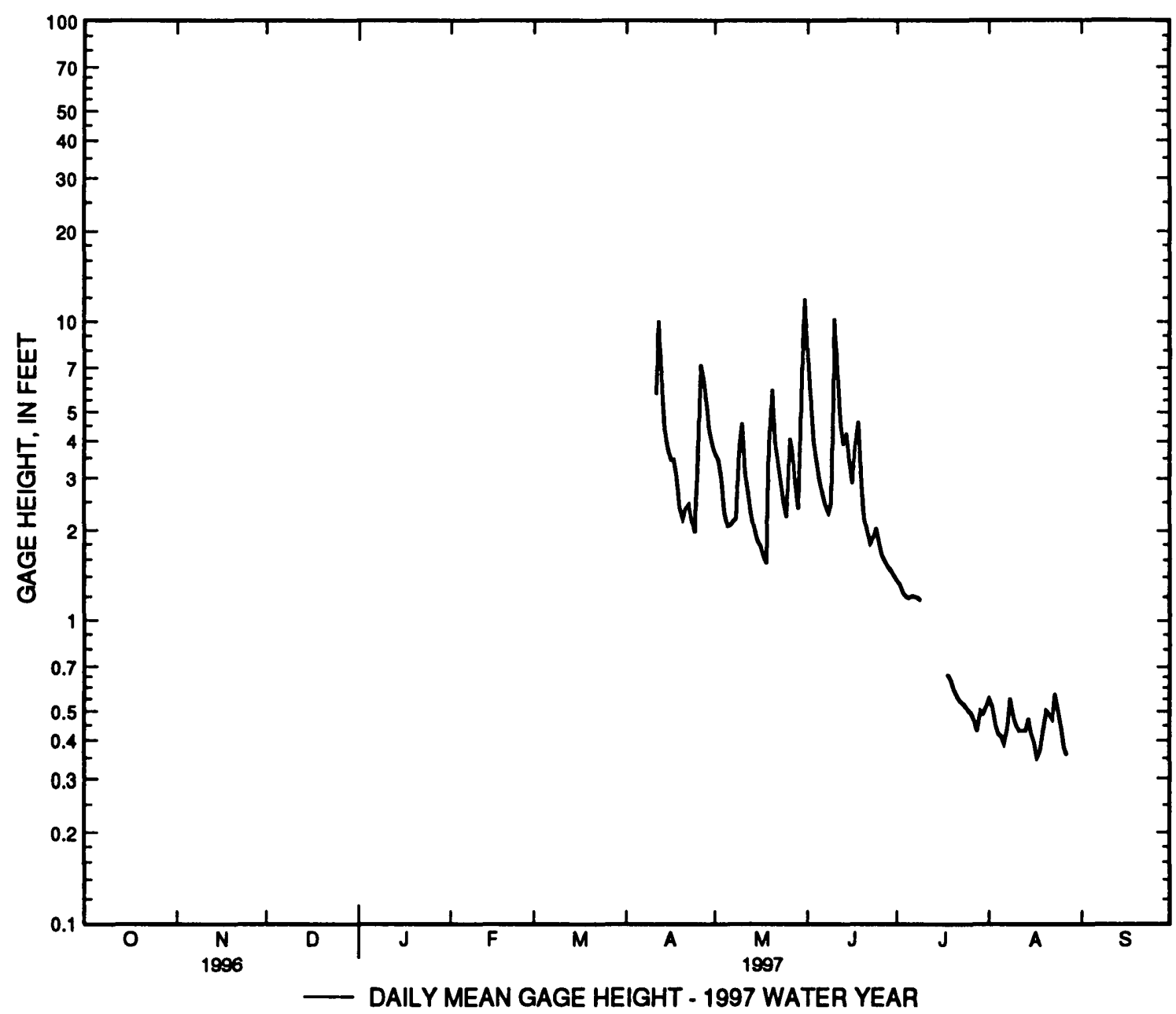




\section{WATER-QUALITY RECORDS}

PERIOD OF RECORD.--April 1997 to September 1997 (discontinued).

PERIOD OF DAILY RECORD.-

SPECIFIC CONDUCTANCE: April 1997 to September 1997 (discontinued).

WATER TEMPERATURE: April 1997 to September 1997 (discontinued).

INSTRUMENTATION.--Water-quality monitor since April 1997.

REMARKS.--Interruptions in record were due to malfunction of the recording instruments. Water temperature, specific conductance, pH, alkalinity, and dissolved oxygen were determined in the field.

EXTREMES FOR CURRENT YEAR (April 1997 to September 1997).--

SPECIFIC CONDUCTANCE: Maximum, 1,480 microsiemens, Sept. 1; minimum, 119 microsiemens, May 30.

WATER TEMPERATURE: Maximum, $34.5^{\circ} \mathrm{C}$, July 28; minimum, $11.0^{\circ} \mathrm{C}$, Apr. 13.

\begin{tabular}{|c|c|c|c|c|c|c|c|c|c|c|}
\hline & & & & & ATER-QU & ITY DATA & & & & \\
\hline DATE & TIME & $\begin{array}{l}\text { AGENCY } \\
\text { COL- } \\
\text { LECTING } \\
\text { SAMPLE } \\
\text { (CODE } \\
\text { NUMBER) } \\
(00027)\end{array}$ & $\begin{array}{l}\text { AGENCY } \\
\text { ANA- } \\
\text { LYZING } \\
\text { SAMPLE } \\
\text { (CODE } \\
\text { NUMBER) } \\
(00028)\end{array}$ & $\begin{array}{c}\text { DIS- } \\
\text { CHARGE, } \\
\text { INST. } \\
\text { CUBIC } \\
\text { FEET } \\
\text { PER } \\
\text { SECOND } \\
(00061)\end{array}$ & $\begin{array}{l}\text { SPE- } \\
\text { CIFIC } \\
\text { CON- } \\
\text { DUCT- } \\
\text { ANCE } \\
\text { (US/CM) } \\
(00095)\end{array}$ & $\begin{array}{c}\text { PH } \\
\text { WATER } \\
\text { WHOLE } \\
\text { FIELD } \\
\text { (STAND- } \\
\text { ARD } \\
\text { UNITS) } \\
(00400)\end{array}$ & $\begin{array}{c}\text { TEMPER- } \\
\text { ATURE } \\
\text { AIR } \\
(\text { DEG C) } \\
(00020)\end{array}$ & $\begin{array}{c}\text { TEMPER- } \\
\text { ATURE } \\
\text { WATER } \\
\text { (DEG C) } \\
(00010)\end{array}$ & $\begin{array}{c}\text { TUR- } \\
\text { BID- } \\
\text { ITY } \\
\text { (NTU) } \\
(00076)\end{array}$ & $\begin{array}{c}\text { BARO- } \\
\text { METRIC } \\
\text { PRES- } \\
\text { SURE } \\
\text { (MM } \\
\text { OF } \\
\text { HG) } \\
(00025)\end{array}$ \\
\hline OCT 19 & & & & & & & & & & \\
\hline $\begin{array}{l}18 \ldots \\
\text { JUL } 19\end{array}$ & $\begin{array}{l}1315 \\
97\end{array}$ & 1028 & 81213 & 21 & 624 & 8.1 & 18.0 & 17.5 & 3.4 & 756 \\
\hline $31 \ldots$ & 1500 & 1028 & 81213 & -- & 909 & 8.5 & -- & 32.0 & 10 & 753 \\
\hline $\begin{array}{l}31 \ldots \\
\text { AUG }\end{array}$ & 2015 & 1028 & 81213 & -- & 851 & 8.3 & -- & 30.5 & 10 & 750 \\
\hline $01 \ldots$ & 0210 & 1028 & 81213 & -- & 870 & 8.1 & -- & 28.5 & 10 & 751 \\
\hline $01 \ldots$ & 0815 & 1028 & 81213 & -- & 918 & 8.2 & -- & 27.0 & 12 & 748 \\
\hline $01 \ldots$ & 1400 & 1028 & 81213 & -- & 1020 & 8.5 & -- & 30.0 & 12 & 754 \\
\hline $28 \ldots$ & 2230 & 1028 & 81213 & -- & 1300 & 8.1 & -- & 28.5 & 20 & 745 \\
\hline $29 \ldots$ & 0420 & 1028 & 81213 & -- & 1210 & 8.0 & -- & 26.5 & 11 & 740 \\
\hline $29 \ldots$ & 1020 & 1028 & 81213 & -- & 1250 & 8.0 & -- & 26.5 & 5.4 & 741 \\
\hline $29 \ldots$ & 1600 & 1028 & 81213 & -- & 1290 & 8.3 & -- & 31.5 & 5.7 & 740 \\
\hline $29 \ldots$ & 2200 & 1028 & 81213 & -- & 1240 & 8.0 & -- & 29.0 & 13 & 740 \\
\hline DATE & $\begin{array}{c}\text { OXYGEN, } \\
\text { DIS- } \\
\text { SOLVED } \\
(M G / L) \\
(00300)\end{array}$ & $\begin{array}{l}\text { OXYGEN, } \\
\text { DIS- } \\
\text { SOLVED } \\
\text { (PER- } \\
\text { CENT } \\
\text { SATUR- } \\
\text { ATION) } \\
\text { (00301) }\end{array}$ & $\begin{array}{c}\text { OXYGEN } \\
\text { DEMAND, } \\
\text { BIOCHEM } \\
\text { CARBON. } \\
20 \\
(M G / L) \\
(80087)\end{array}$ & $\begin{array}{c}\text { OXYGEN } \\
\text { DEMAND, } \\
\text { BIOCHEM } \\
\text { CARBON. } \\
\text { 20-FILT. } \\
\text { (MG/L) }\end{array}$ & $\begin{array}{c}\text { ALKA- } \\
\text { LINITY } \\
\text { WAT DIS } \\
\text { TOT IT } \\
\text { FIELD } \\
\text { MG/L AS } \\
\text { CACO3 } \\
(39086)\end{array}$ & $\begin{array}{c}\text { SULFIDE } \\
\text { TOTAL } \\
\text { (MG/L } \\
\text { AS S) } \\
(00745)\end{array}$ & $\begin{array}{l}\text { SULFATE } \\
\text { DIS- } \\
\text { SOLVED } \\
\text { (MG/L } \\
\text { AS SO4) } \\
(00945)\end{array}$ & $\begin{array}{l}\text { NITRO- } \\
\text { GEN, } \\
\text { NITRATE } \\
\text { TOTAL } \\
\text { (MG/L } \\
\text { AS N) } \\
(00620)\end{array}$ & $\begin{array}{l}\text { NITRO- } \\
\text { GEN, } \\
\text { NITRITE } \\
\text { TOTAL } \\
\text { (MG/L } \\
\text { AS N) } \\
(00615)\end{array}$ & $\begin{array}{c}\text { NITRO- } \\
\text { GEN, } \\
\text { NO2+NO3 } \\
\text { TOTAL } \\
\text { (MG/L } \\
\text { AS N) } \\
(00630)\end{array}$ \\
\hline OCT 1996 & & & & & & & & & & \\
\hline $\begin{array}{l}18 \ldots \\
\text { JUL } 1997\end{array}$ & 9.7 & 102 & -- & -- & 173 & $<1.0$ & 39 & 1.79 & .210 & 2.00 \\
\hline $31 \ldots$ & 11.2 & 155 & 6.3 & 1.6 & 166 & -- & -- & 3.23 & .066 & 3.30 \\
\hline $\begin{array}{c}31 \ldots \\
\text { AUG }\end{array}$ & 8.2 & 112 & 3.6 & 2.0 & 161 & -- & -- & 2.65 & .053 & 2.70 \\
\hline $01 \ldots$ & 6.4 & 84 & 3.3 & 1.5 & 169 & -- & - & 2.65 & .052 & 2.70 \\
\hline $01 \ldots$ & 5.8 & 74 & 3.3 & 1.6 & 168 & -- & -- & 2.45 & .047 & 2.50 \\
\hline $01 \ldots$ & 10.7 & 144 & 4.7 & 3.5 & 164 & -- & -- & 3.05 & .048 & 3.10 \\
\hline $28 \ldots$ & 8.0 & 106 & 4.7 & 3.1 & 150 & -- & -- & 4.44 & .062 & 4.50 \\
\hline $29 \ldots$ & 6.2 & 80 & 4.4 & 3.5 & 150 & -- & - & 4.33 & .066 & 4.40 \\
\hline $29 \ldots$ & 6.7 & 86 & 3.8 & 4.1 & 152 & -- & -- & 3.92 & .080 & 4.00 \\
\hline $29 \ldots$ & 10.6 & 148 & 5.9 & 9.2 & 152 & -- & -- & 4.01 & .086 & 4.10 \\
\hline $29 \ldots$ & 6.9 & 93 & 4.8 & 3.9 & 154 & -- & -- & 4.20 & .098 & 4.30 \\
\hline
\end{tabular}


07330800 CADDO CREEK SITE 9, COMPARATIVE SAMPLE SITE NEAR GENE AUTRY, OK--Continued

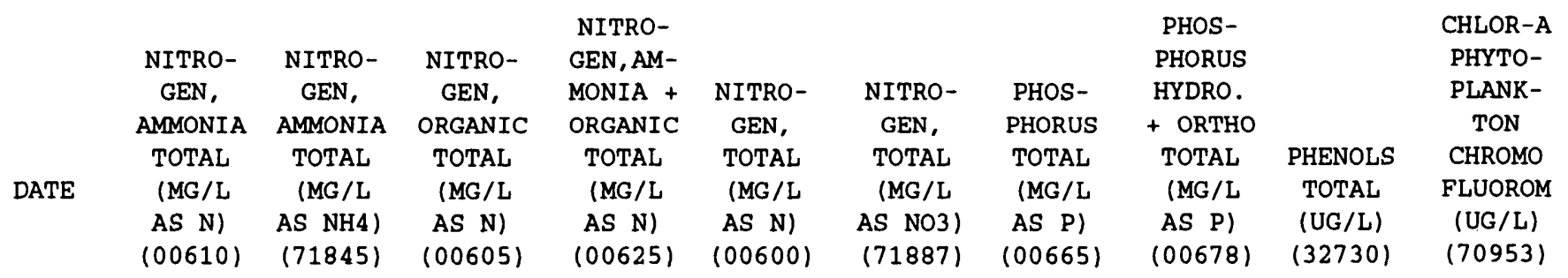

$\begin{array}{lll}\text { OCT } 1996 & & \\ 18 \ldots & .420 & .54 \\ \text { JUL } 1997 & & \\ 31 \ldots & .050 & .06 \\ 31 \ldots & .050 & .06 \\ \text { AUG } & & \\ 01 \ldots & .090 & .1 \\ 01 \ldots & .100 & .13 \\ 01 \ldots & .050 & .06 \\ 28 \ldots & .030 & .04 \\ 29 \ldots & .080 & .10 \\ 29 \ldots & .070 & .09 \\ 29 \ldots & .030 & .04 \\ 29 \ldots & .050 & .06\end{array}$

$\begin{array}{lllllllll}.54 & .50 & .92 & 2.9 & 13 & .370 & .36 & <1 & 2.50 \\ .06 & .82 & .87 & 4.2 & 18 & .880 & .81 & -- & 29.0 \\ .06 & .68 & .73 & 3.4 & 15 & .760 & .70 & -- & 10.0 \\ .12 & .73 & .82 & 3.5 & 16 & .760 & .70 & -- & 8.10 \\ .13 & .90 & 1.0 & 3.5 & 15 & .760 & .72 & -- & 3.20 \\ .06 & .83 & .88 & 4.0 & 18 & .770 & .76 & -- & 29.0 \\ .04 & 1.6 & 1.6 & 6.1 & 27 & .980 & 1.1 & -- & 6.90 \\ .10 & 1.4 & 1.5 & 5.9 & 26 & 1.10 & 1.1 & -- & 13.0 \\ .09 & 1.3 & 1.4 & 5.4 & 24 & 1.10 & 1.0 & -- & 13.0 \\ .04 & 1.6 & 1.6 & 5.7 & 25 & 1.50 & 1.1 & -- & 13.0 \\ .06 & 1.6 & 1.7 & 6.0 & 27 & 1.70 & 1.1 & -- & 11.0\end{array}$

$\begin{array}{lcc}\text { DATE } & \text { (CODE } & \text { (CODE } \\ & \text { NUMBER) } & \text { NUMBER) } \\ & (00027) & (00028) \\ \text { AUG 01-29 } & 1028 & 81213 \\ \text { AUG 01-29 } & 1028 & 81213 \\ \text { AUG 01-29 } & 1028 & 81213\end{array}$

PERI-
PHYTON
BIOMASS
ASH
WEIGHT
G/SQ M
$(00572)$
3.55
7.11
2.93

$\begin{array}{cc}\text { PERI- } & \text { CHLOR-A } \\ \text { PHYTON } & \text { PERI- } \\ \text { BIOMASS } & \text { PHYTON } \\ \text { TOTAL } & \text { CHROMO- } \\ \text { DRY } & \text { GRAPHIC } \\ \text { WEIGHT } & \text { FLUOROM } \\ \text { G/SQ M } & \text { (MG/M2) } \\ (00573) & (70957) \\ 50.9 & 1440 \\ 74.4 & 1690 \\ 5.80 & 1090\end{array}$

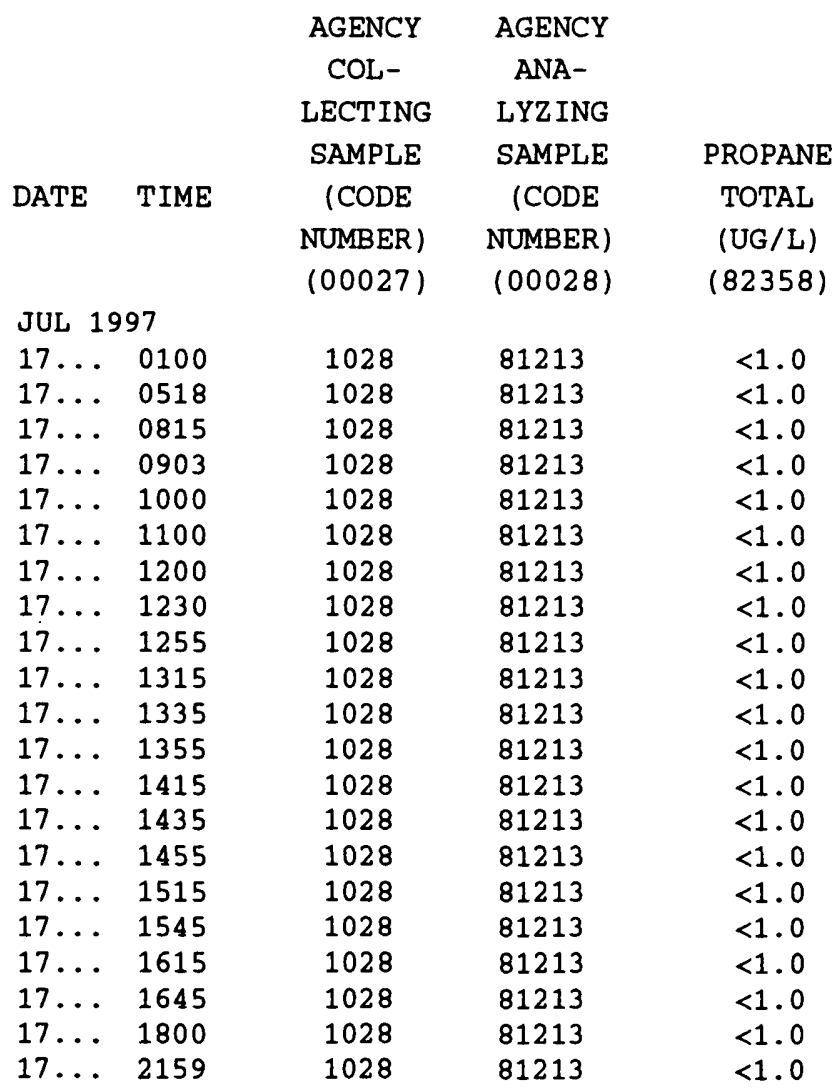


07330800 CADDO CREEK. SITE 9, COMPARATIVE SAMPLE SITE NEAR GENE AUTRY, OK--Continued SPECIFIC CONDUCTANCE, US/CM @ 25 DEGREES CELSIUS, WATER YEAR OCTOBER 1996 TO SEPTEMBER 1997

\begin{tabular}{|c|c|c|c|c|c|c|c|c|c|c|c|c|}
\hline DAY & MAX & MIN & MEAN & MAX & MIN & MEAN & MAX & MIN & MEAN & MAX & MIN & MEAN \\
\hline & & BRUAF & & & MARCH & & & APR II & & & MAY & \\
\hline 1 & --- & -- & -- & -- & $\ldots$ & -- & -- & --- & --- & 689 & 586 & 643 \\
\hline 2 & -- & -- & -- & -- & -- & -- & -- & -- & -- & 712 & 679 & 698 \\
\hline 3 & -- & -- & -- & -- & -- & -- & -- & --- & --- & 749 & 685 & 722 \\
\hline 4 & --- & -- & --- & --- & --- & --- & -- & --- & --- & 779 & 732 & 759 \\
\hline 5 & -- & $\cdots$ & -- & --- & -- & -- & -- & --- & --- & 786 & 730 & 762 \\
\hline 6 & $\cdots$ & -- & -- & -- & -- & -- & -- & -- & -- & 762 & 731 & 743 \\
\hline 7 & -- & -- & --- & --- & --- & -- & -- & --- & --- & 866 & 762 & 808 \\
\hline 8 & -- & -- & -- & --- & --- & -- & -- & --- & -- & 937 & 866 & 911 \\
\hline 9 & -- & --- & -- & --- & -- & --- & -- & --- & --- & 1020 & 558 & 788 \\
\hline 10 & -- & -- & --- & -- & -- & -- & -- & -- & $\cdots$ & 594 & 508 & 530 \\
\hline 11 & -. & -- & - - & --- & --- & -.- & 881 & 289 & 524 & 555 & 538 & 544 \\
\hline 12 & -.. & $\ldots$ & --. & -.. & $\ldots$ & $\ldots$ & 498 & 344 & 372 & 593 & 555 & 574 \\
\hline 13 & --- & --- & --- & -- & -- & --- & 440 & 383 & 414 & 721 & 593 & 660 \\
\hline 14 & --- & -- & -- & --- & -- & -- & 504 & 440 & 469 & 781 & 721 & 750 \\
\hline 15 & -- & -- & -- & -- & -- & --- & 571 & 504 & 538 & 846 & 769 & 817 \\
\hline 16 & -- & -- & -- & --- & --- & -- & 635 & 571 & 602 & 977 & 839 & 893 \\
\hline 17 & $-\cdots$ & --- & -.- & -. & -- & -- & 684 & 635 & 666 & 996 & 891 & 934 \\
\hline 18 & -- & -- & -- & --- & -- & -- & 828 & 673 & 725 & 908 & 874 & 892 \\
\hline 19 & -- & --- & -- & -- & -- & -- & 777 & 734 & 762 & 906 & 290 & 595 \\
\hline 20 & -- & -- & -- & --- & -- & --- & 814 & 777 & 806 & 551 & 285 & 411 \\
\hline 21 & --- & --- & -.- & --- & --- & -.- & 830 & 787 & 809 & 535 & 428 & 466 \\
\hline 22 & -- & --- & -- & --- & --- & -- & 818 & 685 & 736 & 535 & 512 & 524 \\
\hline 23 & -- & -- & -- & --- & -- & --- & 770 & 676 & 718 & 568 & 530 & 5 \\
\hline 24 & --- & --- & -- & --- & -- & -- & 942 & 770 & 855 & 631 & 567 & 594 \\
\hline 25 & --- & $\ldots$ & -- & --- & --- & --- & 998 & 344 & 830 & 665 & 631 & 648 \\
\hline 26 & -- & -- & -- & -- & -- & --- & 732 & 315 & 438 & 778 & 646 & 703 \\
\hline 27 & -- & -- & -- & --- & $\cdots$ & -- & 490 & 420 & 444 & 837 & 647 & 729 \\
\hline 28 & -- & --- & $\cdots$ & -- & -- & --- & 472 & 448 & 460 & 677 & 641 & 654 \\
\hline 29 & --- & -- & -- & --- & $-\cdots$ & -- & 511 & 471 & 488 & 641 & 620 & 629 \\
\hline 30 & $\cdots$ & $\cdots$ & -- & --- & $\cdots$ & -- & 587 & 511 & 541 & 628 & 119 & 378 \\
\hline 31 & -- & -- & -- & --- & -- & $\cdots$ & -1 & -- & -- & 326 & 224 & 274 \\
\hline ITT & -- & -- & ... & -- & $\ldots$ & -- & -- & -- & -- & 1020 & 119 & 664 \\
\hline
\end{tabular}


07330800 CADDO CREEK SITE 9, COMPARATIVE SAMPLE SITE NEAR GENE AUTRY, OK--Continued

SPECIFIC CONDUCTANCE, US/CM @ 25 DEGREES CELSIUS, WATER YEAR OCTOBER 1996 TO SEPTEMBER 1997

\begin{tabular}{|c|c|c|c|c|c|c|c|c|c|c|c|c|}
\hline \multirow[t]{2}{*}{ DAY } & MAX & MIN & MEAN & MAX & MIN & MEAN & MAX & MIN & MEAN & MAX & MIN & MEAN \\
\hline & & JUNE & & \multicolumn{3}{|c|}{ JULY } & \multicolumn{3}{|c|}{ AUGUST } & \multicolumn{3}{|c|}{ SEPTEMBER } \\
\hline $\begin{array}{l}1 \\
2 \\
3 \\
4 \\
5\end{array}$ & $\begin{array}{l}409 \\
504 \\
562 \\
642 \\
740\end{array}$ & $\begin{array}{l}325 \\
407 \\
504 \\
562 \\
642\end{array}$ & $\begin{array}{l}369 \\
442 \\
530 \\
610 \\
685\end{array}$ & $\begin{array}{l}946 \\
970 \\
969 \\
987 \\
994\end{array}$ & $\begin{array}{l}926 \\
919 \\
935 \\
959 \\
943\end{array}$ & $\begin{array}{l}932 \\
940 \\
953 \\
974 \\
982\end{array}$ & $\begin{array}{r}982 \\
948 \\
1020 \\
1120 \\
1160\end{array}$ & $\begin{array}{r}870 \\
884 \\
891 \\
974 \\
1030\end{array}$ & $\begin{array}{r}926 \\
916 \\
966 \\
1040 \\
1080\end{array}$ & $\begin{array}{l}1480 \\
1390 \\
1210 \\
1140 \\
1190\end{array}$ & $\begin{array}{l}1390 \\
1180 \\
1140 \\
1020 \\
1020\end{array}$ & $\begin{array}{l}1450 \\
1250 \\
1180 \\
1060 \\
1080\end{array}$ \\
\hline $\begin{array}{r}6 \\
7 \\
8 \\
9 \\
10\end{array}$ & $\begin{array}{l}780 \\
860 \\
892 \\
880 \\
577\end{array}$ & $\begin{array}{l}740 \\
780 \\
843 \\
148 \\
148\end{array}$ & $\begin{array}{l}763 \\
825 \\
873 \\
823 \\
334\end{array}$ & $\begin{array}{l}943 \\
902 \\
884 \\
946 \\
995\end{array}$ & $\begin{array}{l}890 \\
838 \\
832 \\
884 \\
946\end{array}$ & $\begin{array}{l}911 \\
867 \\
860 \\
917 \\
966\end{array}$ & $\begin{array}{r}1210 \\
1220 \\
1080 \\
981 \\
1200\end{array}$ & $\begin{array}{r}1120 \\
1070 \\
863 \\
833 \\
879\end{array}$ & $\begin{array}{r}1150 \\
1120 \\
1000 \\
894 \\
992\end{array}$ & $\begin{array}{r}1020 \\
860 \\
863 \\
884 \\
888\end{array}$ & $\begin{array}{l}839 \\
815 \\
819 \\
823 \\
851\end{array}$ & $\begin{array}{l}894 \\
833 \\
842 \\
862 \\
869\end{array}$ \\
\hline $\begin{array}{l}11 \\
12 \\
13 \\
14 \\
15\end{array}$ & $\begin{array}{l}410 \\
420 \\
540 \\
631 \\
484\end{array}$ & $\begin{array}{l}319 \\
377 \\
411 \\
438 \\
468\end{array}$ & $\begin{array}{l}367 \\
408 \\
437 \\
502 \\
476\end{array}$ & $\begin{array}{r}1010 \\
983 \\
989 \\
--- \\
---\end{array}$ & $\begin{array}{l}983 \\
903 \\
894 \\
--- \\
---\end{array}$ & $\begin{array}{l}998 \\
959 \\
940 \\
--- \\
---\end{array}$ & $\begin{array}{r}1210 \\
942 \\
1200 \\
1170 \\
1110\end{array}$ & $\begin{array}{l}937 \\
915 \\
910 \\
992 \\
985\end{array}$ & $\begin{array}{r}1070 \\
930 \\
1050 \\
1100 \\
1070\end{array}$ & $\begin{array}{l}--- \\
--- \\
--- \\
--- \\
---\end{array}$ & $\begin{array}{l}--- \\
--- \\
--- \\
--- \\
---\end{array}$ & $\begin{array}{l}--- \\
--- \\
--- \\
--- \\
---\end{array}$ \\
\hline $\begin{array}{l}16 \\
17 \\
18 \\
19 \\
20\end{array}$ & $\begin{array}{r}553 \\
581 \\
1110 \\
844 \\
760\end{array}$ & $\begin{array}{l}472 \\
552 \\
581 \\
705 \\
682\end{array}$ & $\begin{array}{l}495 \\
566 \\
801 \\
747 \\
727\end{array}$ & $\begin{array}{r}855 \\
968 \\
1050 \\
966 \\
962\end{array}$ & $\begin{array}{l}834 \\
841 \\
906 \\
905 \\
816\end{array}$ & $\begin{array}{l}844 \\
920 \\
968 \\
935 \\
901\end{array}$ & $\begin{array}{r}1250 \\
1290 \\
1300 \\
1010 \\
920\end{array}$ & $\begin{array}{r}919 \\
1100 \\
1010 \\
796 \\
781\end{array}$ & $\begin{array}{r}1000 \\
1190 \\
1180 \\
882 \\
843\end{array}$ & $\begin{array}{l}--- \\
--- \\
--- \\
--- \\
---\end{array}$ & $\begin{array}{l}--- \\
--- \\
--- \\
--- \\
---\end{array}$ & $\begin{array}{l}--- \\
--- \\
--- \\
--- \\
-\cdots\end{array}$ \\
\hline $\begin{array}{l}21 \\
22 \\
23 \\
24 \\
25\end{array}$ & $\begin{array}{l}788 \\
832 \\
859 \\
873 \\
826\end{array}$ & $\begin{array}{l}728 \\
784 \\
744 \\
746 \\
768\end{array}$ & $\begin{array}{l}768 \\
815 \\
826 \\
833 \\
794\end{array}$ & $\begin{array}{r}919 \\
963 \\
1050 \\
1060 \\
1010\end{array}$ & $\begin{array}{l}839 \\
878 \\
963 \\
945 \\
924\end{array}$ & $\begin{array}{r}875 \\
917 \\
1020 \\
1030 \\
963\end{array}$ & $\begin{array}{r}927 \\
928 \\
1160 \\
1190 \\
900\end{array}$ & $\begin{array}{l}699 \\
708 \\
857 \\
865 \\
834\end{array}$ & $\begin{array}{r}811 \\
811 \\
1040 \\
1030 \\
863\end{array}$ & $\begin{array}{l}--- \\
--- \\
--- \\
--- \\
---\end{array}$ & $\begin{array}{l}--- \\
--- \\
--- \\
--- \\
---\end{array}$ & $\begin{array}{l}-- \\
-\cdots \\
--- \\
--- \\
--\end{array}$ \\
\hline $\begin{array}{l}26 \\
27 \\
28 \\
29 \\
30 \\
31\end{array}$ & $\begin{array}{l}906 \\
911 \\
950 \\
943 \\
942 \\
\ldots--\end{array}$ & $\begin{array}{l}826 \\
889 \\
905 \\
925 \\
927 \\
---\end{array}$ & $\begin{array}{l}862 \\
902 \\
936 \\
935 \\
935 \\
---\end{array}$ & $\begin{array}{r}1100 \\
1040 \\
1080 \\
1100 \\
1040 \\
998\end{array}$ & $\begin{array}{l}984 \\
998 \\
998 \\
969 \\
938 \\
869\end{array}$ & $\begin{array}{r}1040 \\
1020 \\
1050 \\
1050 \\
989 \\
945\end{array}$ & $\begin{array}{r}995 \\
1060 \\
1280 \\
1270 \\
1400 \\
1420\end{array}$ & $\begin{array}{r}843 \\
949 \\
1010 \\
1200 \\
1170 \\
1370\end{array}$ & $\begin{array}{r}919 \\
1020 \\
1130 \\
1240 \\
1260 \\
1390\end{array}$ & $\begin{array}{l}--- \\
--- \\
--- \\
-- \\
-- \\
--\end{array}$ & $\begin{array}{l}--- \\
--- \\
--- \\
--- \\
--- \\
---\end{array}$ & $\begin{array}{l}--- \\
--- \\
--- \\
--- \\
--- \\
--\end{array}$ \\
\hline NTH & 1110 & 148 & 680 & --- & $-\cdots$ & --- & 1420 & 699 & 1030 & -- & -- & -- \\
\hline
\end{tabular}


07330800 CADDO CREEK SITE 9, COMPARATIVE SAMPLE SITE NEAR GENE AUTRY, OK--Continued

WATER TEMPERATURE, DEGREES CELSIUS, WATER YEAR OCTOBER 1996 TO SEPTEMBER 1997

\begin{tabular}{|c|c|c|c|c|c|c|c|c|c|c|c|c|}
\hline \multirow[t]{2}{*}{ DAY } & MAX & MIN & MEAN & MAX & MIN & MEAN & MAX & MIN & MEAN & MAX & MIN & MEAN \\
\hline & \multicolumn{3}{|c|}{ FEBRUARY } & \multicolumn{3}{|c|}{ MARCH } & \multicolumn{3}{|c|}{ APRIL } & \multicolumn{3}{|c|}{ MAY } \\
\hline 1 & -- & --- & $\cdots$ & -- & -- & - & -- & --- & --- & 22.0 & 19.0 & 20.5 \\
\hline 2 & -- & $\cdots$ & -.- & -- & 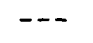 & $\cdots$ & -.- & -. & --- & 25.0 & 20.5 & 22.0 \\
\hline 3 & -- & -- & --- & -- & -- & -- & --- & --- & --- & 23.5 & 19.5 & 21.5 \\
\hline 4 & --- & --- & $\cdots$ & $\cdots$ & -.. & $\cdots$ & --- & --- & --- & 23.0 & 18.5 & 20.5 \\
\hline 5 & --- & -- & --- & --- & -.. & -. & -- & -.. & -.- & 24.5 & 20.0 & 22.0 \\
\hline 6 & -- & --- & $-\cdots$ & -- & -. & $\cdots$ & --- & -- & --- & 26.5 & 22.0 & 24.0 \\
\hline 7 & -- & --- & $\cdots$ & $\cdots$ & -- & -- & --- & --- & -- & 26.0 & 23.5 & 24.5 \\
\hline 8 & --- & --- & --- & --- & -- & -- & --- & --- & --- & 25.5 & 23.0 & 24.0 \\
\hline 9 & -- & --- & -- & --- & -- & --- & -- & --- & -- & 24.0 & 21.0 & 22.0 \\
\hline 10 & $\cdots$ & --- & --- & -- & --- & -- & --- & --- & --- & 21.5 & 19.0 & 20.5 \\
\hline 11 & -- & --- & -- & -- & -- & -- & 18.0 & 13.5 & 15.5 & 23.0 & 19.5 & 21.0 \\
\hline 12 & -- & --- & --- & --- & -- & -- & 13.5 & 11.5 & 12.0 & & & 21.0 \\
\hline 13 & -- & --- & --- & -- & -- & -- & 13.0 & 11.0 & 12.0 & 23.0 & 17.5 & 20.0 \\
\hline 14 & -- & --- & --- & -- & -.- & -- & 15.0 & 12.0 & 13.0 & 23.5 & 20.5 & 22.0 \\
\hline 15 & -- & -- & $\cdots$ & -- & -.- & $-\cdots$ & 17.0 & 13.5 & 15.0 & 24.5 & 20.5 & 22.0 \\
\hline 16 & -- & --- & -- & --- & --- & -- & 18.5 & 15.5 & 17.0 & 27.0 & 21.0 & 23.5 \\
\hline 17 & $\cdots$ & -- & -- & -- & --- & --- & 20.5 & 16.5 & 18.5 & 28.5 & 22.5 & 25.5 \\
\hline 18 & -- & -.- & $\cdots$ & -- & --- & -- & 20.0 & 17.0 & 18.5 & 30.0 & 24.5 & 27.0 \\
\hline 19 & -- & -- & $\ldots$ & --- & --- & $\cdots$ & & 17 & & 27 & & 23.5 \\
\hline 20 & $\cdots$ & --- & -.- & -- & --- & -- & 24.5 & 19.5 & 21.5 & 21.5 & 20.5 & 21.0 \\
\hline 21 & -- & -- & --- & --- & -- & -- & 24.5 & 20.5 & 22.5 & 20.5 & 20.0 & 20.5 \\
\hline 22 & -- & -- & -- & -. & -- & - & & & & & & 21.5 \\
\hline 23 & $\cdots$ & --- & --- & --- & --- & -- & 21.5 & 19.0 & 20.5 & 23.5 & 22.5 & 23.0 \\
\hline 24 & --- & --- & --- & --- & --- & --- & 20.0 & 17.0 & 18.0 & 26.5 & 22.5 & 24.0 \\
\hline 25 & -- & -.- & & - & --- & -- & 17.0 & 13.5 & 15.0 & 28.0 & 24.5 & 26.0 \\
\hline 26 & -- & --- & -- & --- & --- & --- & 14.0 & 13.5 & 13.5 & 30.0 & 25.5 & 27.0 \\
\hline 27 & $\cdots$ & -.- & $\cdots$ & --- & -- & -- & 15.0 & 14.0 & 14. & 29.0 & & 28.0 \\
\hline 28 & --- & --- & - & -1 & --- & - & 17.5 & & & & & 26.5 \\
\hline 29 & --- & --- & $\cdots$ & --- & --- & --- & 20.5 & 17.0 & 18 & 27 & 24 & 25.5 \\
\hline 30 & -- & -.- & $\cdots$ & -- & --- & -- & 22.0 & 20.0 & 21.0 & 25.5 & 20.5 & 23.0 \\
\hline 31 & --- & -.. & $\cdots$ & -- & --- & -- & --- & --- & -- & 23.5 & 21.5 & 22.5 \\
\hline $\mathrm{NTH}$ & --- & -. & $\cdots$ & -- & -- & -.- & --- & --- & --- & 30.0 & 17.5 & 23.1 \\
\hline
\end{tabular}


07330800 CADDO CREEK SITE 9, COMPARATIVE SAMPLE SITE NEAR GENE AUTRY, OK--Continued

WATER TEMPERATURE, DEGREES CELSIUS, WATER YEAR OCTOBER 1996 TO SEPTEMBER 1997

\begin{tabular}{|c|c|c|c|c|c|c|c|c|c|c|c|c|}
\hline \multirow[t]{2}{*}{$D A Y$} & MAX & MIN & MEAN & MAX & MIN & MEAN & MAX & MIN & MEAN & MAX & MIN & MEAN \\
\hline & \multicolumn{3}{|c|}{ JUNE } & \multicolumn{3}{|c|}{ JULY } & \multicolumn{3}{|c|}{ AUGUST } & \multicolumn{3}{|c|}{ SEPTEMBER } \\
\hline $\begin{array}{l}1 \\
2 \\
3 \\
4 \\
5\end{array}$ & $\begin{array}{l}24.5 \\
25.0 \\
24.5 \\
25.5 \\
26.5\end{array}$ & $\begin{array}{l}22.5 \\
23.5 \\
23.0 \\
23.0 \\
23.0\end{array}$ & $\begin{array}{l}23.5 \\
24.0 \\
24.0 \\
24.0 \\
24.5\end{array}$ & $\begin{array}{l}33.0 \\
33.5 \\
34.0 \\
32.5 \\
28.0\end{array}$ & $\begin{array}{l}28.5 \\
28.5 \\
29.0 \\
28.0 \\
24.5\end{array}$ & $\begin{array}{l}30.5 \\
31.0 \\
31.5 \\
29.5 \\
26.5\end{array}$ & $\begin{array}{l}31.5 \\
31.5 \\
31.5 \\
33.0 \\
33.0\end{array}$ & $\begin{array}{l}27.0 \\
27.0 \\
27.0 \\
27.0 \\
28.0\end{array}$ & $\begin{array}{l}29.0 \\
29.0 \\
29.0 \\
30.0 \\
30.0\end{array}$ & $\begin{array}{l}32.5 \\
32.5 \\
30.0 \\
28.0 \\
28.5\end{array}$ & $\begin{array}{l}26.5 \\
27.0 \\
27.5 \\
26.0 \\
24.0\end{array}$ & $\begin{array}{l}29.0 \\
29.0 \\
28.5 \\
27.0 \\
26.0\end{array}$ \\
\hline $\begin{array}{r}6 \\
7 \\
8 \\
9 \\
10\end{array}$ & $\begin{array}{l}26.5 \\
26.5 \\
25.5 \\
26.5 \\
22.5\end{array}$ & $\begin{array}{l}23.5 \\
23.5 \\
24.0 \\
16.0 \\
16.0\end{array}$ & $\begin{array}{l}25.0 \\
25.0 \\
24.5 \\
24.0 \\
21.0\end{array}$ & $\begin{array}{l}27.5 \\
27.5 \\
31.5 \\
32.5 \\
33.0\end{array}$ & $\begin{array}{l}24.5 \\
25.0 \\
25.5 \\
27.5 \\
28.0\end{array}$ & $\begin{array}{l}26.0 \\
26.0 \\
28.5 \\
30.0 \\
30.5\end{array}$ & $\begin{array}{l}29.5 \\
26.0 \\
23.0 \\
28.0 \\
30.5\end{array}$ & $\begin{array}{l}26.0 \\
22.0 \\
21.5 \\
21.0 \\
26.0\end{array}$ & $\begin{array}{l}28.0 \\
24.0 \\
22.0 \\
24.0 \\
28.0\end{array}$ & $\begin{array}{l}29.0 \\
29.0 \\
29.0 \\
28.5 \\
28.0\end{array}$ & $\begin{array}{l}24.0 \\
24.0 \\
25.0 \\
25.0 \\
23.0\end{array}$ & $\begin{array}{l}26.0 \\
26.0 \\
26.5 \\
26.5 \\
25.0\end{array}$ \\
\hline $\begin{array}{l}11 \\
12 \\
13 \\
14 \\
15\end{array}$ & $\begin{array}{l}24.5 \\
27.0 \\
28.5 \\
28.5 \\
29.0\end{array}$ & $\begin{array}{l}22.5 \\
24.5 \\
25.5 \\
27.0 \\
27.0\end{array}$ & $\begin{array}{l}23.5 \\
25.5 \\
27.0 \\
27.5 \\
28.0\end{array}$ & $\begin{array}{l}33.0 \\
33.0 \\
33.5 \\
--- \\
--\end{array}$ & $\begin{array}{l}28.0 \\
28.0 \\
28.5 \\
--- \\
---\end{array}$ & $\begin{array}{l}30.5 \\
30.5 \\
30.5 \\
-- \\
--\end{array}$ & $\begin{array}{l}29.5 \\
30.5 \\
31.0 \\
32.5 \\
31.5\end{array}$ & $\begin{array}{l}27.5 \\
26.5 \\
27.5 \\
27.5 \\
27.5\end{array}$ & $\begin{array}{l}28.5 \\
28.5 \\
29.0 \\
29.5 \\
29.5\end{array}$ & $\begin{array}{l}--- \\
-- \\
--- \\
--- \\
--\end{array}$ & $\begin{array}{l}--- \\
--- \\
--- \\
--- \\
---\end{array}$ & $\begin{array}{l}--- \\
--- \\
--- \\
--- \\
---\end{array}$ \\
\hline $\begin{array}{l}16 \\
17 \\
18 \\
19 \\
20\end{array}$ & $\begin{array}{l}30.0 \\
29.5 \\
29.5 \\
31.0 \\
32.0\end{array}$ & $\begin{array}{l}27.0 \\
26.5 \\
26.5 \\
26.5 \\
28.0\end{array}$ & $\begin{array}{l}28.0 \\
28.0 \\
28.0 \\
28.5 \\
29.5\end{array}$ & $\begin{array}{l}32.5 \\
32.5 \\
31.0 \\
32.0 \\
33.0\end{array}$ & $\begin{array}{l}26.5 \\
28.5 \\
28.0 \\
27.5 \\
28.0\end{array}$ & $\begin{array}{l}29.5 \\
30.5 \\
29.5 \\
29.5 \\
30.5\end{array}$ & $\begin{array}{l}32.0 \\
31.5 \\
33.0 \\
29.5 \\
32.0\end{array}$ & $\begin{array}{l}27.0 \\
28.0 \\
27.5 \\
27.0 \\
26.5\end{array}$ & $\begin{array}{l}29.0 \\
29.5 \\
29.0 \\
28.5 \\
29.0\end{array}$ & $\begin{array}{l}--- \\
--- \\
--- \\
--- \\
---\end{array}$ & $\begin{array}{l}--- \\
--- \\
--- \\
--- \\
---\end{array}$ & $\begin{array}{l}--- \\
--- \\
--- \\
--- \\
---\end{array}$ \\
\hline $\begin{array}{l}21 \\
22 \\
23 \\
24 \\
25\end{array}$ & $\begin{array}{l}31.5 \\
30.0 \\
28.0 \\
29.0 \\
31.0\end{array}$ & $\begin{array}{l}28.0 \\
27.0 \\
26.0 \\
25.5 \\
26.5\end{array}$ & $\begin{array}{l}29.5 \\
28.5 \\
27.0 \\
27.0 \\
28.5\end{array}$ & $\begin{array}{l}33.5 \\
33.0 \\
33.0 \\
34.0 \\
34.0\end{array}$ & $\begin{array}{l}28.5 \\
28.5 \\
28.0 \\
28.5 \\
29.5\end{array}$ & $\begin{array}{l}30.5 \\
30.0 \\
30.0 \\
31.0 \\
31.5\end{array}$ & $\begin{array}{l}32.0 \\
30.0 \\
29.5 \\
29.5 \\
30.0\end{array}$ & $\begin{array}{l}27.0 \\
26.0 \\
26.0 \\
25.0 \\
25.0\end{array}$ & $\begin{array}{l}29.5 \\
28.5 \\
27.5 \\
27.5 \\
27.5\end{array}$ & $\begin{array}{l}--- \\
--- \\
--- \\
--- \\
---\end{array}$ & $\begin{array}{l}--- \\
--- \\
--- \\
--- \\
--\end{array}$ & $\begin{array}{l}--- \\
--- \\
--- \\
--- \\
---\end{array}$ \\
\hline $\begin{array}{l}26 \\
27 \\
28 \\
29 \\
30 \\
31\end{array}$ & $\begin{array}{l}31.5 \\
32.5 \\
31.5 \\
32.5 \\
32.5 \\
---\end{array}$ & $\begin{array}{l}27.0 \\
27.5 \\
28.5 \\
27.5 \\
28.0 \\
---\end{array}$ & $\begin{array}{l}29.0 \\
29.5 \\
30.0 \\
30.0 \\
30.0 \\
---\end{array}$ & $\begin{array}{l}34.0 \\
34.0 \\
34.5 \\
33.5 \\
31.5 \\
32.0\end{array}$ & $\begin{array}{l}29.0 \\
29.5 \\
29.0 \\
28.5 \\
27.5 \\
26.5\end{array}$ & $\begin{array}{l}31.5 \\
31.5 \\
31.5 \\
30.5 \\
29.0 \\
29.0\end{array}$ & $\begin{array}{l}30.0 \\
30.5 \\
31.0 \\
31.5 \\
31.5 \\
32.0\end{array}$ & $\begin{array}{l}25.0 \\
25.0 \\
25.0 \\
25.5 \\
26.5 \\
26.0\end{array}$ & $\begin{array}{l}27.5 \\
27.5 \\
28.0 \\
28.0 \\
28.5 \\
28.5\end{array}$ & $\begin{array}{l}--- \\
--- \\
--- \\
--- \\
--- \\
---\end{array}$ & $\begin{array}{l}--- \\
--- \\
-\cdots \\
--- \\
---\end{array}$ & $\begin{array}{l}--- \\
--- \\
--- \\
--- \\
--- \\
---\end{array}$ \\
\hline ONTH & 32.5 & 16.0 & 26.7 & --- & -- & --- & 33.0 & 21.0 & 28.1 & -- & $\ldots$ & --- \\
\hline
\end{tabular}


As the number of streams on which streamflow information is likely to be desired far exceeds the number of stream-gaging stations feasible to operate at one time, the Geological Survey collects limited streamflow data at sites other than stream-gaging stations. When limited streamflow data are collected on a systematic basis over a period of years for use in hydrologic analyses, the site at which the data are collected is called a partial-record station. Data collected at these partial-record stations are usable in low-flow or floodflow analyses, depending on the type of data collected. In addition, discharge measurements are made at other sites not included in the partial-record program. These measurements are generally made in times of drought or flood to give better areal coverage to those events. Those measurements and others collected for some special reason are called measurements at miscellaneous sites.

\begin{tabular}{llccc}
\hline & & & \multicolumn{2}{c}{ Measurements } \\
\cline { 3 - 5 } $\begin{array}{c}\text { Station } \\
\text { number }\end{array}$ & Station name & Location & $\begin{array}{c}\text { Period } \\
\text { of } \\
\text { record }\end{array}$ & $\begin{array}{c}\text { Date } \\
\text { Discharge } \\
\left(\mathrm{ft}^{3} / \mathrm{s}\right)\end{array}$ \\
\hline
\end{tabular}

RED RIVER BASIN

07330610 Caddo Creek Site 6, Com- Lat $34^{\circ} 14^{\prime} 33^{\prime \prime}$, long $97^{\circ} 04^{\prime} 05^{\prime \prime}$ in NW 1/4, NW 1/4, parative Sample Site near Ardmore, OK

07330615 Sand Creek Site 1, Point Source from Wastewater Plant near Ardmore, OK

07330625 Sand Creek Site 3, Comparative Sample Site near Ardmore, OK

07330665 Sand Creek Site 4, Comparative Sample Site near Ardmore, OK

07330680 Sand Creek Site 5, Comparative Sample Site near Ardmore, OK

07330720 Caddo Creek Site 8, Comparative Sample Site near Gene Autry, OK

07330800 Caddo Creek Site 9, Comparative Sample Site near Gene Autry, OK sec.2, T.4S, R.2E, Carter County, Hydrologic Unit 11130303 , on right bank 0.9 mi above Sand Creek, $4.8 \mathrm{mi}$ northeast of Ardmore, and at mile 11.1.

Lat $34^{\circ} 12^{\prime} 28^{\prime \prime}$, long $97^{\circ} 05^{\prime} 47^{\prime \prime}$ in SW $1 / 4$, NE $1 / 4$, sec.16, T.4S, R.2E, Carter County, Hydrologic Unit 11130303 , on left bank at south edge of the Ardmore Wastewater Treatment Plant northeast of Ardmore, and at mile 4.8.

Lat $34^{\circ} 12^{\prime} 47^{\prime \prime}$, long $97^{\circ} 05^{\prime} 25^{\prime \prime}$ in NE $1 / 4$, NE $1 / 4$, sec.10, T.4S, R.2E, Carter County, Hydrologic Unit 11130303, on left bank adjacent to Atchison Topeka and Sante Fe Railroad tracks, $1.0 \mathrm{mi}$ downstream from City of Ardmore Wastewater Treatment Plant, and at mile 4.1.

Lat $34^{\circ} 13^{\prime} 49^{\prime \prime}$, long $97^{\circ} 04^{\prime} 22^{\prime \prime}$ in NW $1 / 4$, NW $1 / 4$, sec.11, T.4S, R.2E, Carter County, Hydrologic Unit 11130303 , on downstream left bank at county road bridge, $3.0 \mathrm{mi}$ north of U.S. Highway $70,4.0 \mathrm{mi}$ northeast of Ardmore city limits, and at mile 1.1. Lat $34^{\circ} 14^{\prime} 12^{\prime \prime}$, long $97^{\circ} 03^{\prime} 39^{\prime \prime}$ in SE $1 / 4$, SE $1 / 4$, sec.2, T.4S, R.2E, Carter County, Hydrologic Unit 11130303 , on right bank $500 \mathrm{ft}$ downstream from low-water crossing on private land, $0.3 \mathrm{mi}$ above Caddo Creek, 3.4 mi north of U.S. Highway 70,6.5 mi northeast of Ardmore city limits, and at mile 0.3.

Lat $34^{\circ} 13^{\prime} 58^{\prime \prime}$, long $97^{\circ} 02^{\prime} 16^{\prime \prime}$ in SW $1 / 4$, SW $1 / 4$, sec.6, T.4S, R.3E, Carter County, Hydrologic Unit 11130303 , on right bank $3.0 \mathrm{mi}$ north of U.S. Highway $70,3.8 \mathrm{mi}$ south of Gene Autry, and at mile 7.1. Lat $34^{\circ} 13^{\prime} 51^{\prime \prime}$, long $97^{\circ} 00^{\prime} 47^{\prime \prime}$ in SE $1 / 4$, SW $1 / 4$, sec.5, T.4S, R.3E, Carter County, Hydrologic Unit 11130303 , on left downstream bank $3.0 \mathrm{mi}$ south of Gene Autry, $1.5 \mathrm{mi}$ east, $1 \mathrm{mi}$ south on private land, and at mille 3.3.
1997

10-18-96

07-15-97

08-26-97

1997

07-17-97

3.1

1997

07-15-97

4.4

07-17-97

5.9

08-26-97

7.8

1997

07-16-97

07-18-97

5.3

4.4

1997

10-18-96

07-16-97

3.8

07-18-97

4.6

5.4

1997

07-15-97

14

07-17-97

18

1997

10-18-96

21

07-15-97

16

07-17-97

17

08-26-97

9.9

9.9
4.4

\section{4}

\section{1}

and

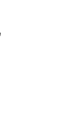


Access to USGS Water Data .54

Accuracy of the Records. 51

Acre-foot, definition of .54

Algae, definition of .54

Arrangement of Records. .52

Artificial substrate, definition of. .56

Ash mass, definition of .54

B

Biochemical oxygen demand, definition of .........54

Biomass, definition of. 54

Blue-green algae, definition of .55

$\mathrm{C}$

Caddo Creek near Ardmore 58,60

Caddo Creek Site 6, Comparative Sample Site near Ardmore

Caddo Creek Site 6, Point Source Upstream from Sand Creek Confluence near Ardmore 72

Caddo Creek Site 7, Comparative Sample Site near Gene Autry 94, 96

Caddo Creek Site 8, Comparative Sample Site near Gene Autry... 111,122

Caddo Creek Site 9, Comparative Sample Site near Gene Autry $113,116,122$

Caddo Creek Site 9A near Gene Autry............... 113

Chlorophyll, definition of ........................................ 54

Classification of Records .....................................55

Code Numbers, definition of................................. 54

Control, definition of ............................................54

Cubic foot per second, definition of .....................54 D

Data Collection and Computation 49

Data Presentation 49,53

Data Table of Daily Mean Values 50

Definition of Terms................................................. 54

Diatoms, definition of ............................................ 55

Discharge, definition of .......................................54

Dissolved, definition of.......................................... 54

Dissolved-solids concentration, definition of ..... 54

Downstream Order System.................................. 49

Drainage area, definition of ..................................55

Drainage basin, definition of.................................... 55

Dry mass, definition of .......................................... 54 G

Gage height, definition of . 55

Gaging station, definition of .55

Green algae, definition of .55

$\mathrm{H}$

Hydrograph 51

Hydrologic unit, definition of

\section{I}

Identifying Estimated Discharge............................51

Instantaneous discharge, definition of .................54

L

Laboratory Measurements 53

$M$

Mean discharge, definition of 54

Micrograms per liter, definition of......................... 55

Milligrams per liter, definition of .

$\mathrm{N}$

Natural substrate, definition of 56

Nutrient Calculations. 54

0

On-site Measurements and Sample Collection...52

Organic mass, definintion of..................................54

Organism, definition of.........................................55

Count/area, definition of .................................55

Count/volume, definition of............................ 55

$P$

Parameter Code, definition of. 55

Partial-record station, definition of ........................55

Periphyton, definition of ........................................ 55

Phytoplankton, definition of ..................................55

Plankton, definition of .......................................... 55

$\mathbf{R}$

Records of Surface-Water Quality.......................52

Remark Codes. .53

\section{$S$}

Sand Creek Site 1, Point Source from Wastewater Plant near Ardmore $74,77,122$

Sand Creek Site 2, Point Source from Wastewater Plant near Ardmore .82

Sand Creek Site 3, Comparative Sample Site near Ardmore 87,122

Sand Creek Site 3A near Ardmore 89

Sand Creek Site 3B near Ardmore .89

Sand Creek Site 4, Comparative Sample Site near Ardmore 90,122

Sand Creek Site 5, Comparative Sample Site near Ardmore 92,122

Sea Level, definition of......................................... 55

Solute, definition of ...........................................56

Specific conductance, definition of.........................56

Stage-discharge relation, definition of...................56

Station Identification Numbers........................... 49

Station Manuscript.............................................55

Statistics of Monthly Mean Data .........................50

Streamflow, definition of ......................................56

Substrate, definition of..............................................56 
Summary Statistics 50

Suspended, definition of 56

Suspended, recoverable, definition of................. 56

Suspended, total, definition of ........................... 56 $T$

Total organism count, definition of 55

Total recoverable, definition of. 56

Total, definition of 56
Water Quality-Control Data..............................53

Water Temperature ........................................... 53

Water year, definition of ....................................56

Wet mass, definition of....................................... 54

WSP, definition of ........................................57

Z

Zooplankton, definition of . 
(3) Printed on recycled paper 